UNITED STATES DEPARTMENT OF THE INTERIOR

Harold L. Ickes, Secretary

GEOLOGICAL SURVEY

W. C. Mendenhall, Director

Professional Paper 191

\title{
A MONOGRAPH OF THE FORAMINIFERAL \\ FAMILY NONIONIDAE
}

BY

JOSEPH A. CUSHMAN

UNITED STATES

GOVERNMENT PRINTING OFFICE

WASHINGTON : 1939

For sale by the Superintendent of Documents, Washington, D. C. - - - - Price 30 cents 


\section{CONTENTS}

Introduction

Acknowledgments _...

Available material _ _

Questionable material_.

Systematic descriptions

ILLUSTRATIONS

Plates 1-20. Foraminifera of the family Nonionidae. 


\title{
A MONOGRAPH OF THE FORAMINIFERAL FAMILY NONIONIDAE
}

\author{
By Joseph A. Cushman
}

\section{INTRODUCTION}

The Foraminifera belonging to the family Nonionidae are in many localities extremely numerous, particularly in shallow waters of the Tropics. Many of the species have been greatly confused since the first description, and it is hoped that this paper will help to make more definite the species belonging to this family. There is still much work to be done on the distribution of many of these forms, both in the present oceans and in the geologic sequence. The studies of the older records have seemed to prove that the descriptions of numerous forms involved mixing of material and that some of these forms rather clearly did not come from the formations to which they were assigned. Also, some of the species are inadequately described, a number of them are not even figured, and others are illustrated by figures which are either very much conventionalized or represent inadequately the characteristics necessary for their determination. Descriptions of most of the new species discovered during this work have been published elsewhere, so that the records might be available to other workers before publication of the present paper. That there are other undescribed species is very clear from material in our hands which through poor preservation or inadequacy cannot be satisfactorily described at this time.

\section{ACKNOWLEDGMENTS}

The completion of this work was made possible by a grant from the Penrose bequest of the Geological Society of America. This has allowed the completion of the illustrations and the manuscript as well as the preparation for study of much available material which was previously unorganized. My thanks are therefore due, first of all, to the projects committee, who approved the plan of work, and to the Council of the Geological Society, who approved the report of the projects committee.

My thanks are also due to the assistants in the Cushman Laboratory for Foraminiferal Research, who have given much time and energy to this work; to Miss Ann Shepard, for her careful and accurate drawing of the many species, results of which appear on the accompanying plates; to Miss Frances L. Parker, for her assistance in organizing the material for study and for the photographing of many original illustrations for use on the plates; and to Miss Patricia G. Edwards, for her painstaking work with the manuscript.
I am also indebted to very many persons for material illustrating various species of this family, particularly to Mr. W. J. Parr, of Australia, who has supplied me with excellent series from the Australian region, both fossil and Recent; to Dr. Henry V. Howe, for topotypes of numerous species described by him and others; to Dr. Hollis J. Hedberg, for material from the northern part of South America; to Mr. P. W. Jarvis, of Trinidad, for collections from that area; and to many other persons who have contributed much in the way of material toward the completion of these studies.

This work was originally started as a joint undertaking with the late David $\mathrm{H}$. Leavitt, a graduate student at Harvard University, who at the time of his death was studying with me as part of his work for a doctorate in paleontology. A preliminary paper entitled "On Elphidium macellum (Fichtel and Moll), E. striato-punctatum (Fichtel and Moll), and E. crispum (Linné)" was published in the Contributions from the Cushman Laboratory for Foraminiferal Research, vol. 5, pp. 18-22, 1929. We had at that time also segregated much topotype material from various localities illustrating numerous species, particularly of Elphidium. At that time the late Dr. Yoshiaki Ozawa had returned to my laboratory from a year spent in Europe, bringing with him large collections which he made particularly in the Miocene of the Vienna Basin. As a result, excellent series of the species of that area which had been compared with D'Orbigny's material so far as it was preserved in Europe were made available by Dr. Ozawa. This series has been of immense value in this work.

\section{AVAILABLE MATERIAL}

During the years that this work has been in progress material has been assembled from many different areas, so that topotype material is available of a large percentage of those species that are not represented in this collection by either paratype or holotype specimens. Large series of many species have been obtained which show well the range in variation of these species, and were it not for the expense in publication many more specimens could have been illustrated on the plates to show this particular fact. Rich material has been available from the West Indies region and extending southward along the Atlantic coast of South America to the Falkland Islands, covering most of D'Orbigny's work of 1839 and his Cuban monograph and that recorded in his "Voyage dans l'Amérique méridionale." 
THE FORAMINIFERAL FAMILY NONIONIDAE

The collections made by Dr. Waldo L. Schmitt along the western coast of South America made available much material from this area of D'Orbigny's collecting. Excellent material has been available from the Atlantic and Pacific coasts of North America, including the Arctic collections of Capt. Robert Bartlett from Greenland and the Fox Basin and material collected by various persons representing the faunas of the western coast of Europe and the Mediterranean. From the Red Sea very fine material was furnished by Dr. W. A. Macfadyen. This was particularly important, as it gave topotype material of Elphidium striato-punctatum (Fichtel and Moll) as well as other species. My own collections from Rimini, on the Adriatic, gave material for the early species described by several authors. Very rich Recent material from the Indo-Pacific has been available through the Albatross collections of the United States National Museum. Fossil material - from North and South America, Europe, North Africa, and Australia has been available.

Wherever possible the original types, if available, have been illustrated, usually by drawings of the specimens themselves, as many of the original figures were found to be more or less inaccurate in the finer details. Where holotype and paratype specimens were not available, topotype material has been figured from our collections, and for those species of which topotypes were not available either the original figures have been copied or illustrations have been made from what seemed to be typical specimens. The original figures for many of the copied illustrations are very decidedly conventionalized in character, and it is often impossible to determine with any degree of accuracy just what form the author had before him when he described his species. It is hoped that sometime in the future someone will refigure many of the actual type specimens if they still exist.

\section{QUESTIONABLE MATERIAL}

As is noted in the discussion of several species, there is very evidently a mixing of material, and from what is known at the present time some of the species, particularly of Elphidium, could not well have come from the formations to which they are assigned. This is particularly true of some of Terquem's species and those of others who have described material from the preTertiary. The most obvious example of this is Faujasina, and a detailed.discussion of this matter will be found under that genus.

\section{SYSTEMATIC DESCRIPTIONS}

Family NONIONIDAE

Test typically planispiral, more or less involute in the adult, trochoid in a few genera and even uncoiled; wall calcareous, finely perforate; aperture simple or cribrate, if simple, at the base of the apertural face.

The Nonionidae were probably derived from a planispirally coiled form, as the earliest of the species that seem rather definitely to belong to Nonion are simple and planispirally coiled. Such forms occur in the Jurassic, although in the Cretaceous they do not seem to have been well developed. In the Cretaceous there are several species of Nonionella, and this gives some possible evidence that the family might have been derived from a trochoid ancestry which became planispiral. This derivation of the family cannot be proved until more is known of the forms of the Jurassic.

It is evident, however, that the simpler forms of Elphidium developed directly from Nonion by the addition of the pores along the sutures and the development of retral processes. Species are known in which the characteristics of Elphidium are not developed until the last two or three chambers of the adult, and the entire younger stages, if found alone, would unhesitatingly be described as Nonion. It is very evident that some of the later, if not all, of the species of Nonionella have developed from Nonion, many of the Miocene forms being much more like Nonion than Nonionella.

Elphidium includes some very complex, large tests, particularly in shallow tropical waters of present oceans. These forms make up a very considerable proportion of beach sands about many tropical islands.

From Elphidium late in its history have developed three of the most specialized genera of the family. Faujasina comprises trochoid forms that were probably attached by the dorsal side, which was flattened or slightly concave; the ventral side was convex and involute. Polystomellina includes trochoid forms in which the dorsal side has a definite spire, somewhat conical, and the ventral side is usually flattened. In Ozawaia the test becomes uncoiled and the aperture terminal and cribrate. This is similar to the developments seen in many other groups of the Foraminifera. It is interesting that this highly specialized form is known only at the present time from Recent collections in the Indo-Pacific.

In the earlier studies of this family some of the arenaceous forms were included, but they are now placed in other families. The genera Bradyina and Cribrospira are included in the Lituolidae, as these are truly arenaceous forms allied to Haplophragmoides and Endothyra. Pullenia has a similar form to Nonion, but its development places it in the Chilostomellidae. Hantkenina has occasionally been included in the Nonionidae, but its early form shows that it developed from the Globigerinidae. Laticarinina, placed by its authors first in the Lagenidae and later in the Nonionidae, is truly trochoid in young individuals and belongs in the Anomalinidae.

\section{Genus NONION Montfort, 1808}

Nonion Montfort, Conchyliologie systématique, vol. 1, p. 211, 1808.

Cushman, Cushman Lab. Foram. Research Contr., vol. 3, p. $170,1927$.

Galloway and Wissler, Jour. Paleontology, vol. 1, p. 81, 1927. 
Cushman, Jour. Paleontology, vol. 1, p. 156, 1927; Cushman Lab. Foram. Research Special Pub. 1, p. 204, 1928.

White, Jour. Paleontology, vol. 3, p. 55, 1929.

Cushman, U. S. Nat. Mus. Bull. 104, pt. 7, p. 2, 1930; Bull. 161, pt. 2, p. 41, 1933; Cushman Lab. Foram. Research Special Pub. 4, p. 193, 1933.

Melonis Montfort, Conchyliologie systématique, vol. 1, p. 67, 1808 (genoholotype, Nautilus pompilioides Fichtel and Moll).

Florilus Montfort, Conchyliologie systématique, vol. 1, p. 135, 1808 (genoholotype, Nautilus asterizans Fichtel and Moll).

Pulvinulus (part) Lamarck, 1816.

Placentula (part) Lamarck, 1822.

Cristellaria (part) Lamarck, 1822.

Lenticulina (part) Defrance, 1824 (not Lamarck).

Polystomella (part) Defrance and authors (not Lamarck).

Nonionina D'Orbigny, Annales sci. nat., vol. 7, p. 293, 1826 (genotype, by designation, Nonionina umbilicata D'Orbigny).

Genoholotype, Nautilus incrassatus Fichtel and Moll.

Test free, planispiral, more or less involute, bilaterally symmetrical, periphery broadly rounded to acute; chambers numerous; wall finely perforate; aperture an arched, usually narrow opening between the base of the apertural face and the preceding coil. Jurassic to Recent.

The earliest records for the genus include the Paleozoic, but these are very vague and probably do not really represent this genus. The records for the Jurassic and the Cretaceous are comparatively few. The genus is well developed in the Tertiary, and there are many species, for the most part smooth but some well ornamented. Although there is a considerable amount of variation, most of the species hold their characters closely and are easily determined. They are not longlived as a rule and therefore should prove to be useful as index fossils.

The evolution from Nonion to Elphidium is a gradual one, some of the more simple of the species of Elphidium not being distinguishable from Nonion until the later chambers are formed, when the first of the sutural pores and retral processes appear. Nonion seems to be the most primitive genus of the family, although Nonionella is well developed in the Cretaceous.

\section{JURASSIC SPECIES OF NONION?}

A number of species have been described and figured under the genus Nonionina which evidently do not belong to the Nonionidae and which are noted in the annotated list of species on pages 25,26 . There are a few species of Nonionina, however, which may possibly belong to the genus Nonion, and they are noted below and copies of the original figures given on plate 1.

\section{Nonion? fraasanum (Gümbel) Cushman}

Plate 1, figure 1

Nonionina fraasana Gümbel, Ver. vaterl. Naturkunde Württemberg Jahresb., vol. 18, p. 233, pl. 4, figs. 5a, b, 1862.

The figures show a planispiral test but there is no definite aperture. It is from the Jurassic of Central Europe.
Nonion? nodulosum (Terquem) Cushman

Plate 1, figure 2

Nonionina nodulosa Terquem, Cinquième Mémoire sur les foraminifères du système oolithique, p. 367, pl. 41, figs. 14a, b, 1883.

This is a rather poorly characterized form from the Jurassic of France.

\section{Nonion? subangulosum (Terquem) Cushman}

Plate 1, figure 3

Nonionina subangulosa Terquem, Cinquième Mémoire sur les foraminifères du système oolithique, p. 367 , pl. 41, figs. $15 \mathrm{a}, \mathrm{b}, 1883$.

The type figures are here reproduced. There is evidently an aperture at the base of the apertural face, but otherwise the form resembles Robulus. It is from the Jurassic of France.

\section{Nonion? solidum (Terquem) Cushman}

Plate 1, figure 4

Nonionina solida Terquem, Soc. géol. France Mém., sér. 3, vol. 4 , p. 48 , pl. 5, figs. $7 \mathrm{a}, \mathrm{b}, 1886$.

The original figure, which is here copied, leaves much to be desired as to essential details. It is from the Jurassic fuller's earth of France.

\section{Nonion jarvisi Thalmann}

Plate 1, figure 5

Nonion jarvisi Thalmann, Eclogae geol. Helvetiae, vol. 25, p. 313, 1932.

Nonion cretaceum Cushman and Jarvis [not Nonionina cretacea Schlumberger], U. S. Nat. Mus. Proc., vol. 80, art. 14, p. 41 , pl. 12, figs. 12a, b, 1932.

Test closely coiled, compressed, very slightly umbilicate, periphery subacute; chambers distinct, eight making up the adult coil, of uniform shape, increasing very slightly in size as added; sutures distinct, limbate, very slightly curved; wall smooth, the central umbilical region covered with a layer of clear shell material, in which are tubular spaces connecting with the umbilici, represented by lighter spaces in the clear material; aperture narrow, at the base of the last-formed chamber. Diameter, 0.65; thickness, $0.25 \mathrm{~mm}$.

The types of this species are from the Upper Cretaceous of a pit at Lizard Springs, near Guayaguayare, southeastern Trinidad, British West Indies.

The species has very limbate sutures and a peculiar ornamentation of the umbilical region, where there is a thickening of clear shell material pierced by irregularly curved tubular openings.

The species has been found only at the type locality.

\section{EOCENE SPECIES OF NONION}

\section{Nonion laeve (D'Orbigny) Cushman}

Plate 1, figures 6, 7

Nonionina laevis D'Orbigny, Annales sci. nat., vol. 7, p. 294, no. 11, 1826; Modèles, no. 46, 1826; Prodrome de paléontologie, vol. 2 , p. 406, no. 1304, 1850.

Terquem, Soc. géol. France Mém., sér. 3, vol. 2, p. 44, pl. 2 (10), figs. 12, 13, 14, 1882. 
Test planispiral, compressed, close-coiled, periphery somewhat keeled until toward the later portion, where it becomes broadly rounded, umbilical region with a single rounded boss, somewhat flattened; chambers very distinct, somewhat inflated, narrowed at the inner end, 10 to 12 in the adult coil, of rather uniform shape, increasing slightly in size as added; sutures deeply excavated, slightly curved; wall smooth; aperture a low opening at the base of the inner margin of the lastformed chamber. Diameter $0.60-0.65 \mathrm{~mm}$; thickness $0.28-0.30 \mathrm{~mm}$.

The types of this species are from the upper or middle Eocene of the Paris Basin, where it is common and occurs at numerous localities represented in our collections. On our plate is a photograph of the original model of 1826 by D'Orbigny and a drawing of a specimen from the Eocene of Grignon, near Paris. Terquem records the species from Septeuil and Vaudancourt. It occurs in our material from the Eocene of the Paris Basin at Grignon, Vaudancourt, Courtagnon, Vivray, Montjavoult, Chamery, Cuise de la Motte, Mouchy, St. Félice, St. Frédéric, Cenphon, Beauvais, Chaumont, and Fontenay. It is also in the material from the Eocene near Antwerp.

This is not the same as the Miocene form that has been referred to under the same name.

\section{Nonion rugosum (D'Orbigny) Cushman}

Plate 1, figure 8

Nonionina rugosa D'Orbigny, Annales sci. nat., vol. 7, p. 294, no. 17, 1826; Prodrome de paléontologie, vol. 2, p. 406, no. $1305,1850$.

Fornasini, Accad. sci. Ist. Bologna Mem., ser. 6, vol. 1, p. 12, pl. 3, fig. 3, 1904.

The illustration is a copy of the original figure from the "planches inédites" of D'Orbigny as given in Fornasini's paper. No specimens are found in our material from numerous localities in the Paris Basin Eocene. The type locality is in the Eocene on the bank of the Gironde River near Pauliac.

\section{Nonion graniferum (Terquem) Cushman}

Plate 1, figures 9-11

Nonionina granifera Terquem, Soc. géol. France Mém., sér. 3, vol. 2, p. 42, pl. 2 (10), figs. 8, 9, 1882.

Test planispiral, umbilical region somewhat exposed in the last-formed coil and covered with fine papillae of uniform size, periphery rounded, occasionally spinose; chambers distinct, about eight in the final coil, inflated, of uniform shape, increasing gradually in size as added; sutures deep, very slightly curved; wall smcoth except for the papillate umbilical region; aperture a low opening at the base of the inner margin of the apertural face. Diameter $0.30 \mathrm{~mm}$; thickness $0.15 \mathrm{~mm}$.

Terquem records this species as very rare from the Eocene of the Paris Basin, both at Septeuil and Vaudancourt. Our figured specimen is from the Calcaire. grossier of Montjavoult, near Paris. Copies of Terquem's figures are also given. From our observations it must be a very rare species.

\section{Nonion? stellatum (Terquem) Cushman}

Plate 1, figure 12

Nonionina stellata Terquem, Soc. géol. France Mém., sér. 3, vol. 2, p. 43, pl. 2 (10), figs. 11 a, b, 1882 .

A copy of Terquem's type figure is given. The specimen came from the Eocene of the Paris Basin. No specimens were found in any of the collections from the Paris Basin which I studied. The exact generic position of this species must be left in some doubt until actual specimens can be studied.

\section{Nonion terquemianum Cushman, n. sp.}

Plate 1, figure 13

Nonionina umbilicatula Terquem [not D'Orbigny, 1826], Soc. géol. France Mém., sér. 3, vol. 2, p. 42, pl. 2 (10), figs. 7a, b, 1882.

Test planispiral, close-coiled, umbilical area deeply depressed, periphery subacute, slightly keeled; chambers numerous, about 15 in the adult coil, low, of uniform shape and increasing very gradually in size as added, not inflated; sutures distinct, little if at all depressed, slightly curved; wall smooth; aperture a low, broad opening at the base of the inner margin of the last-formed chamber. Length $0.55 \mathrm{~mm}$; breadth $0.46 \mathrm{~mm}$; thickness $0.20 \mathrm{~mm}$.

Terquem described this species from the Eocene of Septeuil and Vaudancourt, in the Paris Basin.

D'Orbigny had already used the specific name umbilicata in 1826, and the above name is proposed for this Eocene species. The figure on plate 1 is a copy of Terquem's figure. In our collections from Chaumont and Manthelan, in the Eocene of the Paris Basin, this species is very rare.

\section{Nonion latescens (Schwager) Cushman}

Plate 1, figure 14

Nonionina latescens Schwager, Palaeontographica, vol. 30, Pal. Theil, p. 137, pl. 26 (3), figs. 4 a-c, 1883.

The type figure of Schwager is copied on plate 1 . The specimen came from the Eocene of Egypt. I have searched the material from Egypt that I have but have not found the species. According to Schwager's figure it is very broad, almost rhomboid in apertural view.

\section{Nonion planatum Cushman and Thomas}

Plate 1, figure 15

Nonion planatum Cushman and Thomas, Jour. Paleontology, vol. 4 , p. 37, pl. 3, figs. 5a, b, 1930 .

Cushman and Dusenbury, Cushman Lab. Foram. Research Contr., vol. 10, p. 60, pl. 8, figs. 6a, b, 1934.

Test planispiral, close coiled, compressed, bilaterally symmetrical, biumbilicate, periphery rounded; chambers distinct, but not inflated, about 10 in the last-formed coil, which is almost 
completely involute, peripheral face of the last chamber convex; sutures distinct, earlier ones flush with the surface, later ones very slightly depressed, ending in a thickened ring about the umbilici; wall smooth, finely perforate; aperture a crescentlike slit at the base of the last-formed chamber. Maximum diameter, $0.25 \mathrm{~mm}$; minimum diameter, $0.22 \mathrm{~mm}$; thickness, $0.11 \mathrm{~mm}$.

The type of the species is from the Claiborne Eocene Cook Mountain formation, 3 miles on main highway north of Bronson, Sabine County, Tex. The same form also occurs in the Eocene Poway conglomerate of California.

This is probably the species recorded by Weinzierl and Applin ${ }^{1}$ from the Claiborne of Texas as "Nonion umbilicatulus (Montagu) var." and perhaps the same as that recorded by Cole ${ }^{2}$ under the same name from the Guayabal formation of Mexico.

In our material it has occurred in the Claiborne, Lisbon formation, of Lisbon, Miss.; at Gopher Hill, Tombigbee River, Ala. An apparently identical form has also occurred in the Jackson Eocene of Stovall Creek, east of Diboll, and 4 miles east of Diboll, Angelina County, Tex., and on Tarkiln Creek, half a mile above Nueces River, Tex.

The species also occurs in our collections from the following localities in the Claiborne: Lisbon formation, bridge over Falling Creek, 6 miles south of Quitman, Clarke County, Miss., on road to Langsdale; branch at bridge half a mile northeast of River Falls, Covington County, Ala.; Alabama \& Vicksburg Railroad cut 31/4 miles east of Newton, Newton County, Miss.; 1 mile north of Wautubbee station, Clarke County, Miss.; on New Orleans \& Northeastern Railroad; south bank of Tombigbee River at bend three-fourths mile below lock no. 1 and about 1 mile above St. Stephens Bluff, Washington County, Ala.; near center of north line of sec. 8, T. 10 N., R. 4 E., Clarke County, Ala.; Cook Mountain formation, bluff on San Antonio River 4 miles south-southeast of Floresville, Wilson County, Tex.

There are also specimens that seem to be identical with this species in our collections from the upper middle Eocene of Fontenay and from Chamery, both in the Paris Basin.

\section{Nonion wilcoxense Cushman and Ponton \\ Plate 1, figure 16}

Nonion uilcoxensis Cushman and Ponton, Cushman Lab. Foram. Research Contr., vol. 8, p. 64, pl. 8, figs. 11a, b, 1932.

Test small, bilaterally symmetrical, somewhat compressed, deeply umbilicate on both sides, periphery broadly rounded; chambers distinct, inflated, few, five or six in the last-formed coil, increasing rather rapidly in size as added; sutures distinct, depressed, straight, radial; wall smooth, distinctly perforate; aperture a

\footnotetext{
1 Weinzierl, L. L., and Applin, E. R., The Claiborne formation on the coasta domes: Jour. Paleontology, vol. 3, p. 401, 1929.

2 Cole, W. S., A foraminiferal fauna from the Guayabal formation in Mexico: Bull. Am. Paleontology, vol. 14, no. 51, p. 23, pl. 5, fig. 6, 1927.
}

low, elongate, curved opening at the base of the lastformed chamber in the median line. Length 0.25 $\mathrm{mm}$; breadth $0.18 \mathrm{~mm}$; thickness $0.12-0.15 \mathrm{~mm}$.

The types of this species are from the Wilcox Eocene, from railroad cut 1 mile north of Ozark, Ala.

This species may be the ancestral form of the somewhat similar Nonion micrum Cole, which occurs in the later Eocene.

\section{Nonion florinense Cole}

Plate 1, figures 17, 18

Nonion florinensis Cole, Bull. Am. Paleontology, vol. 14, no. 51, p. 22, pl. 4, fig. 4, 1927.

Test somewhat longer than broad, somewhat compressed, periphery broadly rounded, biumbilicate, not completely involute; chambers distinct, slightly inflated, about nine in the last-formed coil, increasing rather rapidly in size in the adult coil; sutures distinct, slightly depressed, very slightly curved; wall smooth except in the umbilical region, which has numerous small spinose projections; aperture a small, low opening in the median line at the base of the last-formed chamber. Length $0.20-0.30 \mathrm{~mm}$; breadth $0.18-0.20 \mathrm{~mm}$; thickness $0.12 \mathrm{~mm}$.

The types of this species are from the Eocene Guayabal formation of Guayabal, Mexico. The figured specimens are topotypes.

\section{Nonion danvillense Howe and Wallace}

Plate 1, figure 19

Nonion danvillensis Howe and Wallace, Louisiana Dept. Cons. Geol. Bull. 2, p. 51, pl. 9, figs. 3a, b, 1932.

Test much compressed, planispiral, sides almost parallel, slightly involute, slightly elongate; periphery rounded, distinctly lobate, chambers fairly numerous, about seven in the last-formed whorl, inflated; sutures distinct, radial, slightly curved, depressed; wall calcareous, thin, finely perforate; aperture a curved slit at the base of the last-formed chamber, bordered by a faint lip. Diameter $0.27 \mathrm{~mm}$; thickness $0.10 \mathrm{~mm}$.

The types of this species are from the Eocene Jackson formation, of Danville Landing, Ouachita River, Catahoula Parish, La. Our figure is a topotype.

The species is close to $N$. micrum Cole but has more chambers.

\section{Nonion micrum Cole}

Plate 1, figures 20-22

Nonion micrus Cole, Bull. Am. Paleontology, vol. 14, no. 51, p. 22 , pl. 5 , fig. 12,1927 ; vol. 14 , no. 53 , p. $211,1928$.

Weinzierl and Applin, Jour. Paleontology, vol. 3, p. 400, pl. 43, figs. 6a-c, 1929.

Cushman, U. S. Geol. Survey Prof. Paper 181, p. 30, pl. 11, figs. 14, 15, 1935.

Test small, compressed, bilaterally symmetrical, periphery subacute; chambers distinct, somewhat involute, rapidly increasing in size as added, about six making up the adult coil; sutures distinct, depressed, slightly curved; wall smooth, finely perforate; aperture median at the base of the apertural face of the chamber, 
with a slight lip. Diameter $0.25-0.32 \mathrm{~mm}$; thickness 0.10-0.13 mm.

The types of this species are from the Eocene Guayabal formation of Guayabal, Mexico. Cole also records it from the Chapapote formation of Chapapote, Mexico. Weinzierl and Applin record it from the Eocene Yegua formation of the Rio Bravo Oil Co.'s Deussen B1 well, depth 4,010 feet, South Liberty domes, Liberty County, Tex. I have had it from the Jackson Eocene at Hays Chapel, Wayne County, Tex.

\section{Nonion mexicanum Cole}

Plate 1, figures 23, 24

Nonion turgidus (Williamson) var. mexicanus Cole, Bull. Am. Paleontology, vol. 14, no. 51, p. 23, pl. 2, fig. 11, 1927.

Test slightly longer than broad, much compressed, umbilical regions slightly depressed, periphery slightly rounded; chambers distinct, very slightly inflated, about nine in the adult coil, increasing rapidly in size in the adult coil; sutures distinct, slightly depressed, very slightly curved; wall smooth, very finely perforate; aperture a low opening at the base of the last-formed chamber in the median line. Length $0.30-0.35 \mathrm{~mm}$; breadth $0.20-0.22 \mathrm{~mm}$; thickness $0.12-0.15 \mathrm{~mm}$.

The types of this species are from the Eocene Guayabal formation of Guayabal, Mexico. Our figured specimens are topotypes. It has also occurred at the following localities in the Claiborne of the Coastal Plain region of the United States: Roadside going down to ferry, Claiborne, Monroe County, Ala.; Lisbon formation, Alabama \& Vicksburg Railroad cut $3 \frac{1}{4}$ miles east of Newton, 200 yards west of milepost 27, west of Meridian, Miss.; Lisbon formation, bridge over Falling Creek 6 miles south of Quitman, on road to Langsdale, Clarke County, Miss.; south bank of Tombigbee River about 9 miles above Jackson, Washington County, Ala.; Lisbon formation, old swimming hole in Double Bridges Creek at Geneva, Ala.

\section{Nonion bonairense Pijpers}

Plate 1, figure 25

Nonion bonairensis Pijpers, Geology and paleontology of Bonaire, p. 65 , text figs. $68-70,1933$.

Test bilaterally symmetrical, slightly asymmetrical, on both sides involute; on one side with large umbilicus. Periphery broadly rounded. There are ca. eight chambers in the last formed coil. Chambers very slowly increasing in size, two last formed chambers tending to uncoil or at the least attaining greater individuality than the preceding chambers. Sutures fairly distinct, almost straight, slightly depressed. Aperture indistinct, at the base of the apertural face.

Length $0.38 \mathrm{~mm}$; thickness $0.18 \mathrm{~mm}$.

This species was described from the upper Eocene of a well near Porta Spaño, Columbia plantation, Bonaire.

\section{Nonion hummelincki Pijpers}

Plate 1, figure 26

Nonion hummelincki Pijpers, Geology and paleontology of Bonaire, p. 66, text figs. 71-73, 1933.

Test slightly asymmetrical, involute on both sides. Periphery rounded. Umbilicus large, especially on one side, where it is slightly raised. There are about 12 chambers in the last formed coil. Chambers low, slowly increasing in height; last formed chambers becoming much longer. Sutures distinct, depressed, gently curved. Aperture not distinct, at the base of the last chamber; apertural face more or less flattened.

Length $0.29 \mathrm{~mm}$; thickness $0.15 \mathrm{~mm}$.

The types are from the upper Eocene from a well near Porta Spaño, Columbia plantation, Bonaire.

This species has the general shape of test and chambers of Nonionina mediocostata Cushman, 1926, from the Miocene of California. However, $N$. hummelincki is not costate, it has a larger umbilicus and less chambers in the last-formed coil, and the transition of the peripheral margin to the apertural face is less rounded than it is in Nonionina mediocostata.

\section{Nonion chapapotense Cole}

Plate 2, figures 1-3

Nonion chapapotensis Cole, Bull. Am. Paleontology, vol. 14, no. 53, p. 210 (10), pl. 1, figs. 18, 19, 1928.

Cushman, U. S. Geol. Survey Prof. Paper 181, p. 30, pl. 11, figs. 9-13, 1935.

Test close-coiled planispirally, the umbilical area on each side very slightly open but filled with a central boss, about which is a narrow, depressed, grooved area, the outer edge of which is slightly thickened, periphery rounded; chambers distinct, numerous, usually about 10 in the adult coil, of uniform shape, gradually increasing in size as added; sutures distinct, somewhat limbate, slightly curved, fusing at the inner end into the thickened ridge at the outside edge of the grooved area about the umbilical boss; wall of the chamber smooth, conspicuously perforate; aperture along the base of the apertural face in the median line. Diameter $0.40 \mathrm{~mm}$; thickness $0.20 \mathrm{~mm}$.

This species was originally described by Cole from the Eocene Chapapote formation of Mexico. It occurs also in the upper Eocene of the Coastal Plain of the southeastern United States as follows: Ocala limestone (Jackson age) 2 miles south of Perry, Ga.; Claiborne, Ala.; 6 $\frac{1}{2}$ miles north of Brooklyn, Ala.; 5 miles southeast of Whatley, Ala.; and at Beck, Ala. It also occurs in the Jackson formation at Yazoo City, Miss.; on Stovall Creek east of Diboll, Tex.; on Bridge Creek $1 \frac{1}{2}$ miles above the Angelina River, Tex.

Specimens show considerable variation, with many intermediate stages between the forms with an open umbilicus and those in which a large boss is developed. 


\section{Nonion whitsettense (Cushman and Applin) Cushman}

Plate 1, figure 27

Nonionina whitsettensis Cushman and Applin, Am. Assoc. Petroleum Geologists Bull., vol. 10, p. 183, pl. 10, figs. 4-6, 1927.

Nonion whitsettensis Ellisor, Am. Assoc. Petroleum Geologists Bull., vol. 17, pl. 2, fig. 14, 1933.

Cushman, U. S. Geol. Survey Prof. Paper 181, p. 31, pl. 11, figs. 16-18, 1935.

Test planispiral, close-coiled, much compressed, the sides flattened and nearly parallel, periphery broadly rounded; chambers distinct, low and broad, 8 to 10 in the last-formed coil, increasing rapidly in length as added in the adult coil; sutures distinct, slightly depressed, strongly curved, especially at the proximal end; wall smooth; aperture a narrow, elongate opening at the base of the narrow apertural face. Length up to $0.50 \mathrm{~mm}$; thickness $0.10-0.12 \mathrm{~mm}$.

The types of this species are from the upper Eocene of the so-called $\dagger$ Whitsett zone ${ }^{2 a}$ from Ohio Red River well 2 , at 330 feet, Tyler County, Tex. It is a characteristic species of this particular zone in many wells in Texas but does not seem to occur in the Eocene of the eastward extension of the Coastal Plain. There seem to be traces of what may be retral processes, but they are not very definite or well developed.

\section{Nonion olssoni (W. Berry) Cushman}

Plate 1, figures 29, 30

Nonionina olssoni W. Berry, Eclogae geol. Helvetiae, vol. 21, p. 403, text figs. 23a-c, 1928.

Test composed of numerous chambers, slightly umbilicate, usually nine chambers in the last volution, broadest at the lastformed coil, periphery broadly rounded, surface pitted, sutures distinct, slightly depressed, aperture a narrow, curved opening at the base of apertural face. Diameter up to $0.94 \mathrm{~mm}$; thickness up to $0.17 \mathrm{~mm}$.

The above description and measurements are copied from the original. The types of the species are from the upper Eocene middle Lobitos shales of northwestern Peru. On our plate is a figure of a specimen from the Chapapote formation of Mexico, from the type locality at Chapapote, which seems to fit the description and figures of this species. A single specimen, also apparently identical, occurred in material from the Jackson Eocene of Haynes no. 1 well, depth 3,175 to 3,270 feet, near Burkeville, Newton County, Tex.

\section{Nonion samanicum (W. Berry) Cushman}

Plate 1, figure 28

Nonionina samanica W. Berry, Eclogae geol. Helvetiae, vol. 21, p. 403, text figs. 13a-c, 1928.

Test subtrochoid, small, periphery broadly rounded, usually seven chambers in the last-formed coil, distinct, sutures distinct, slightly curved. The last chamber with the umbilical end tends to form a very slight lobe on one side, wall smooth and very

2a A dagger ( $f$ ) preceding a geologic name indicates that the name has been abandoned or rejected for use in classification in the publications of the Geological Survey. finely pitted, aperture low elongated slit at base of apertural face. Length $0.47 \mathrm{~mm}$; breadth $0.37 \mathrm{~mm}$; thickness $0.19 \mathrm{~mm}$.

The original description and figures are here copied. The specimens came from the upper Eocene in the lower Lobitos shales of northwestern Peru.

\section{Nonion inexcavatum (Cushman and Applin) Ellisor}

\section{Plate 2, figure 4}

Nonionina advena Cushman var. inexcavata Cushman and Applin, Am. Assoc. Petroleum Geologists Bull., vol. 10, p. 182, pl. 10, figs. 18, 19, 1926.

Nonion inexcavatum Ellisor, Am. Assoc. Petroleum Geologists Bull., vol. 17, pl. 2, fig. 7, 1933.

Cushman, U. S. Geol. Survey Prof. Paper 181, p. 30, pl. 11, figs. 5-8, 1935.

Test of medium size, circular in side view, biconvex, periphery subacute; chambers 12 to 15 in the adult coil, distinct, slightly inflated; sutures very slightly curved, very slightly if at all depressed; umbilical region at each side of the test occupied by a slightly projecting knob of clear shell material, with the area toward the aperture from this knob covered with a pustulose ornamentation, especially marked in adults; aperture low at the base of the last-formed chamber. Maximum diameter $0.85 \mathrm{~mm}$; thickness $0.22 \mathrm{~mm}$.

The types are from the upper Eocene, 4 miles east of Diboll, Angelina County, Tex. It occurs in the Jackson Eocene as follows: Cooper marl, Baldock, S. C.; Ocala limestone, Beck, Ala.; Jackson, Water Valley, Ala.; and Jackson, Miss.

A very similar, apparently identical form occurs in the Claiborne Eocene as follows: Roadside going down to ferry, Claiborne, Monroe County, Ala.; Gosport sand, bluff foot of Gopher Hill, Washington County, Ala; 1 mile southwest of Rockville, Clarke County, Ala.; Tombigbee River about 1 mile below lock 1, threefourths mile above St. Stephens Bluff, Ala.; Rocky Creek 10 miles east of Salitpa, Clarke County, Ala.; Lisbon formation 1 mile north of Wautubbee station on New Orleans \& Northeastern Railroad, Clarke County, Miss.

\section{Nonion ornatissimum Cushman}

Plate 2, figure 5

Nonion ornatissimum Cushman, Cushman Lab. Foram. Research Contr., vol. 12, p. 69, pl. 12, figs. 14a, b, 1936.

Test about as long as broad, periphery rounded, umbilical region thickest, occupied by a series of large, rounded bosses; chambers distinct, slightly inflated, of uniform shape and increasing very slightly in size as added, about 12 in the adult coil; sutures distinct, depressed, slightly curved; wall smooth except for the ornamentation of the umbilical region, distinctly perforate; aperture an elongate, low opening at the base of the inner margin of the last-formed chamber. Length $0.70-0.75 \mathrm{~mm}$; breadth $0.65 \mathrm{~mm}$; thickness $0.35 \mathrm{~mm}$.

The types of this species are from the upper Eocene of Kressenberg, Upper Bavaria, Germany. 


\section{Nonion halkyardi Cushman}

Plate 2, figure 6

Nonion halkyardi Cushman, Cushman Lab. Foram. Research Contr., vol. 12, p. 63, pl. 12, fig. 1, 1936.

Test small, in the adult becoming rapidly broader than in the early stages, biumbilicate, periphery broadly rounded; chambers 10 to 12 in the final coil, distinct, little if at all inflated, increasing gradually in size as added, but rapidly expanding in breadth; sutures distinct, radial, limbate, not depressed; wall smooth, distinctly perforate; aperture a distinctly arched opening at the base of the apertural face. Diameter 0.35$0.40 \mathrm{~mm}$; thickness $0.25 \mathrm{~mm}$.

The types of this species are from the upper Eocene Blue Marl of Biarritz, France. It occurs also in the Eocene Bracklesham beds of Whitecliff Bay, Isle of Wight, England, and in the Clavulina saaboi beds of Neustift, Budapest, Hungary.

\section{Nonion applini Howe and Wallace}

\section{Plate 2, figure 7}

Nonionina scapha (Fichtel and Moll) var. Cushman and Applin, Am. Assoc. Petroleum Geologists Bull., vol. 10, p. 182, pl. 10, figs. 12, 13, 1926.

Nonion applini Howe and Wallace, Louisiana Dept. Cons. Geol. Bull. 2, p. 51, pl. 9, figs. 4a, b, 1932.

Test compressed, sides almost parallel, planispiral, involute; periphery almost circular in outline, slightly rounded; chambers slightly inflated, about 8 or 9 in the last-formed coil; umbilical area slightly depressed; sutures radial, almost straight, distinct, depressed; wall finely perforate, calcareous, thin, umbilicus filled with calcareous beads; aperture a curved slit at the base of the last-formed chamber, protected by a faint lip. Diameter 0.45 $\mathrm{mm}$; thickness $0.2 \mathrm{~mm}$.

This species was described from upper Eocene beds of Jackson age at Danville Landing, Ouachita River, La. It occurs in well samples in the Jackson Eocene of Texas and in the Eocene exposed along the Rio Buena Vista, Vera Cruz, Mexico.

Nonion scaphum (Fichtel and Moll) var. inflatum Cushman and
Ellisor

Plate 2, figure 8

Nonion scaphum (Fichtel and Moll) var. inflalum Cushman and Ellisor, Cushman Lab. Foram. Research Contr., vol. 8, p. 41, pl. 6, figs. 2a, b, 1932.

Ellisor, Am. Assoc. Petroleum Geologists Bull., vol. 17, pl. 7, figs. 7a, b, 1933.

Variety differing from the typical in the more rounded form, somewhat inflated chambers, rather deeply incised sutures, umbilical region often with numerous small papillae, earlier sutures slightly limbate; aperture an elongate, low, curved slit at the base of the apertural face of the last-formed chamber. Length $0.45 \mathrm{~mm}$; breadth $0.40 \mathrm{~mm}$; thickness $0.20 \mathrm{~mm}$.

The type of the variety is from the Jackson Eocene on the east bank of Toro Bayou, $\mathrm{SE}^{1 / 4} \mathrm{NW} 1 / 4$ sec. 6, T. 3 N., R. 11 W., Vernon Parish, La.
This variety is a distinct marker of the Fayette sandstone of Jackson age. It is more circular in outline than the typical form of the species, and the last chambers are more inflated. It may be found finally to be a distinct species.

Nonion laeve (D'Orbigny) var. marginatum Cushman and Ellisor Plate 2, figure 9

Nonion lacvis (D'Orbigny) var. marginatum Cushman and Ellisor, Cushman Lab. Foram. Rescarch Contr., vol. 7, p. 52, pl. 7, figs. 5a, b, 1931.

Ellisor, Am. Assoc. Petroleum Geologists Bull., vol. 17, pl. 2, figs. 8a, b, 1933.

Variety differing from the typical form in the very distinct, somewhat thickened marginal keel and the subacute to acute periphery.

The types of this variety are from the upper Eocene Jackson of Dubois ranch, on Sandies Creek east of Sample, Gonzales County, Tex.

\section{Nonion? marielense Palmer \\ Plate 2, figures 11,12}

Nonion? marielensis Palmer, Soc. cubana historia nat. Mem., vol. 10, p. 127, text figs. $1-3,1936$.

Test small, almost spherical, involute, not umbilicate. Five chambers in final whorl; chambers inflated, increasing rather rapidly in size. Sutures distinctly depressed. Surface of each chamber ornamented by numerous (approximately 20 on the final chamber) very fine, sharp ribs, which are not continuous across the sutures. Aperture very indistinct, apparently not the narrow arched opening at the base of the chamber characteristic of Nonion; a specimen in which the final chamber is broken shows a series of small pores at the base of the chamber and about 6 pores in the chamber face just above the base. Diameter of unbroken cotype $0.36 \mathrm{~mm}$; maximum thickness $0.32 \mathrm{~mm}$; diameter of broken cotype $0.28 \mathrm{~mm}$.

The new species is distinguished by its porous aperture, ornamentation, and almost spherical shape. The most closely related species appears to be Polystomella? obscura Schwager, described from the Eocene of Egypt. Schwager's figures do not show retral processes, and the original reference to the genus Polystomella was doubtful. Both the Cuban and Egyptian species have a porous aperture and costate surface; the Cuban form is, however, more tumid, being nearly spherical, and the costae appear to be more delicate.

The types of this peculiar species are from Oligocene marl about 25 meters south of the entrance gate to the Naval Academy at Mariel, Pinar del Río Province, Cuba, from which it is recorded as very rare.

\section{Nonion havanense Cushman and Bermúdez}

Plate 20, figures 1, 2

Nonion havanense Cushman and Bermúdez, Cushman Lab. Foram. Research Contr., vol. 13, p. 19, pl. 2, figs. 13, 14, 1937.

Test somewhat compressed, slightly depressed in the umbilical regions, completely involute, periphery rounded, 8 to 10 chambers in the adult coil, of uniform shape, increasing very slightly in size as added; sutures distinct, very slightly limbate, not depressed, gently 
curved; wall smooth; aperture low. Length $0.55 \mathrm{~mm}$; breadth $0.48 \mathrm{~mm}$; thickness $0.28 \mathrm{~mm}$.

The types are from the Eocene Tejar Consuelo (upper beds) of Cerro, Habana, Cuba.

\section{Nonion mesonense Cole and Gillespic}

Plate 2, figures 10,16

Nonion scaphus (Fichtel and Moll) var. mesonensis Cole and Gillespie, Bull. Am. Paleontology, vol. 15, no. 57b, p. 132, pl. 2, fig. 3, 1930.

Test somewhat oval or elliptical in outline, about $1 \frac{1}{2}$ times as long as broad, periphery subacute, biumbilicate; chambers distinct, 10 to 12 in the adult coil, increasing in size and length, especially in the later portion of the adult coil, later ones slightly inflated; sutures distinct, earlier ones strongly limbate, later ones depressed, strongly curved; wall smooth, distinctly perforate; aperture a low opening at the base of the apertural face. Length $0.35 \mathrm{~mm}$; breadth $0.25 \mathrm{~mm}$; thickness $0.15 \mathrm{~mm}$.

The types are from the Oligocene Meson formation between kilometer posts 17 and 18 on the Aguila Petroleum Co.'s narrow-gage railroad between Potrero and Tanhuijo, Mexico. Our figured specimen is a topotype.

\section{Nonion affine (Reuss) Cushman}

Plate 2, figure 13

Nonionina affinis Reuss, Deutsche. geol. Gesell. Zeitschr., vol. 3, p. 72 , pl. 5 , figs. $32 \mathrm{a}, \mathrm{b}, 1851$.

Bornemann, Deutsche geol. Gesell. Zeitschr., vol. 7, p. 339 , 1855.

Reuss, Akad. Wiss. Wien Sitzungsber., vol. 48, pt. 1, p. 61, 1863; Acad. royale sci. Belgique Bull., sér. 2, vol. 15, p. 157, 1863; Akad. Wiss. Wien Denkschr., vol. 25, p. 163, 1865.

Clark, U. S. Geol. Survey Bull. 141, p. 92, 1896.

Bagg, Maryland Geol. Survey, Eocene, p. 257, pl. 64, fig. 9, 1901.

Franke, Mus. Natur- und Heimatkunde und Naturwiss. Ver. Magdeburg Abh. und Ber., Band 4, Heft 2, p. 188, pl. 6, figs. 71a, b, 1925 .

Hucke, Naturwiss. Ver. Dessau Ber., Heft 2, p. 15 (list), 1930.

Nonion affinis Cushman, Cushman Lab. Foram. Research Contr., vol. 5, p. 89, pl. 13, figs. 24a, b, 1929.

Nonion depressula Nuttall [not Walker and Jacob], Geol. Soc. London Quart. Jour., vol. 84, p. 102, 1928.

P'anulina affinis Galloway and Morrey [not Pulvinulina affinis Hantken], Bull. Am. Paleontology, vol. 15, no. 55, p. 32, pl. 4, figs. 12a-c, 1929.

Test slightly longer than broad, planispiral, much compressed, periphery broadly rounded, deeply biumbilicate; chambers distinct, 10 to 12 in the adult coil, of uniform shape, increasing regularly in size as added, slightly if at all inflated; sutures distinct, gently curved, slightly if at all depressed, ending at the umbilical region in a slightly thickened rim; wall smooth, finely perforate; aperture a low curved opening at the base of the apertural face. Length $0.45 \mathrm{~mm}$; breadth $0.35 \mathrm{~mm}$; thickness $0.18-0.20 \mathrm{~mm}$.
The types of this species are from the Oligocene of Hermsdorf, near Berlin, Germany. It is recorded from numerous other Oligocene localities of Germany and from the Miocene of northern South America.

In our collections there are specimens from the middle Oligocene of Germany; Hermsdorf, near Berlin;Lobsann, Alsace; Sollingen; Flonheim, Mainz Basin; Dusseldorf; Gelber Berg, near Cassel; Schacht Melvissen, near Oestrum; Duisberg; Doberg, near Bünde; Pietzpuhl; Ahnatal, near Cassel; Brandhorst, near Bünde; and a single specimen from Arco, upper Italy.

\section{Nonion advenum (Cushman) Howe}

Plate 20, figures 3,4

Nonionina advena Cushman, U. S. Geol. Survey Prof. Paper 129 , p. 139, pl. 32, fig. 8, 1922; Prof. Paper 133, p. 50, 1923.

Cushman and Applin, Am. Assoc. Petroleum Geologists Bull., vol. 10, p. 181, pl. 10, figs. 16, 17, 1926.

Nonion advena Howe, Jour. Paleontology, vol. 2, p. 175 (list), 1928.

Cole and Gillespie, Bull. Am. Paleontology, vol. 15, no. 57b, p. 132, pl. 2, fig. 15, 1930.

Cushman, U. S. Geol. Survey Prof. Paper 181, p. 30, pl. 11, figs. 1-4, 1935.

Test small, nearly circular in side view, biconvex in peripheral view, periphery rounded to subacute, umbilical region with a distinct, raised, rounded boss; chambers distinct, 9 to 11 in the adult coil, somewhat inflated, of rather uniform size and shape; sutures distinct, depressed, inner portion excavated and broadened, slightly sigmoid; wall smooth; aperture low, at the base of the apertural face. Length $0.75 \mathrm{~mm}$; breadth $0.60 \mathrm{~mm}$; thickness $0.18-0.25 \mathrm{~mm}$.

This species was originally described from the Oligocene Mint Spring marl member of the Marianna limestone, from Vicksburg and Boice, Miss. It is widely distributed in the Oligocene of the Coastal Plain region of the United States and Mexico. It also occurs at many localities in the upper Eocene Jackson from Texas, Louisiana, Mississippi, Alabama, Florida, and Georgia.

\section{Nonion anomalinum (Cushman) Cushman}

Plate 2, figure 15

Nonionina anomalina Cushman, U. S. Nat. Mus. Bull. 103, p. 74, pl. 26, fig. 2, 1918.

Test in side view nearly circular, deeply biumbilicate, periphery broadly rounded; chambers fairly distinct, about seven in the adult coil, later ones slightly inflated; sutures somewhat indistinct, little if at all depressed; wall smooth, finely perforate; aperture a low slit at the base of the apertural face. Diameter 1.25 $\mathrm{mm}$; thickness $1.00 \mathrm{~mm}$.

The types of this species are from the lower part of the Culebra formation (the lower part of the Culebra formation is considered to be of Oligocene age), north of Pedro Miguel Locks, Panama Canal Zone. 
The last two chambers are suggestive of Cassidulina, but this may be an abnormal condition in the type specimen.

\section{Nonion turgescens Cushman}

Plate 2, figure 14

Nonion turgescens Cushman, Cushman Lab. Foram. Research Contr., vol. 12, p. 64, pl. 12, figs. 2a, b, 1936.

Test much compressed, with a broad, rounded keel and a distinct, rounded umbo; chambers very distinct, 8 to 10 in the adult coil, increasing very gradually in size as added, only slightly inflated; sutures very distinct, slightly sigmoid; wall ornamented by raised pyriform areas in the central portion of the adult chambers, tapering to a point near the umbo; aperture a very narrow, highly arched opening at the base of the apertural face of the last-formed chamber. Diameter $0.30 \mathrm{~mm}$; thickness $0.15 \mathrm{~mm}$.

The types of this species came from the Oligocene of Weinkein bei Alzey, Mainz Basin, Germany.

The species may be distinguished from $N$. laeve (D'Orbigny) in having fewer chambers and in having the raised areas restricted to the middle of the chambers.

\section{Nonion? costatum (Roemer) Cushman}

Nonionina coslata Roemer, Neues Jahrb., 1838, p. 392, pl. 3, fig. 67.

I have not seen material of this species described by Roemer from Tertiary of North Germany. The figure is not very useful to give details, on account of its small size, and the species must be placed with some doubt in the genus Nonion until more is known regarding it.

\section{Nonion? glabrum (Roemer) Cushman}

Nonionina glabra Roemer, Neues Jahrb., 1838, p. 392, pl. 3, fig. 66.

The figure and description of this species also are very inadequate, and the details of the test must await further studies.

\section{Nonion polystomelliforme (Spandel) Cushman}

Nonionina polystomelliformis Spandel, Offenbacher Ver. Naturkunde Ber., 1901-9, p. 216, pl. 2, fig. 9, 1909.

This species was described from the Oligocene of Offenbach, in the Mainz Basin. In the final paper figure 9 of plate 2 is missing, and a note in the explanation of the plate gives the information that the original specimen was lost. The species must therefore remain obscure.

\section{Nonion roemeri Cushman}

Plate 3, figure 1

Nonion roemeri Cushman, Cushman Lab. Foram. Research Contr., vol. 12, p. 65, pl. 12, figs. 3a, b, 1936.

Test somewhat compressed, umbilical regions slightly depressed, periphery broadly rounded; chambers distinct, very slightly inflated, increasing rather rapidly but evenly in size and height as added, 8 to 10 in the adult coil; sutures very distinct, slightly depressed, distinctly curved; wall smooth except the umbilical region, which has a distinct filling of secondary shell material running out slightly over the inner end of the sutures; aperture consisting of a line of small rounded openings at the basal margin of the inner face of the last-formed chamber. Length $0.35-0.40 \mathrm{~mm}$; breadth $0.30-0.35 \mathrm{~mm}$; thickness $0.18-0.20 \mathrm{~mm}$.

The types of this species are from the upper Oligocene of Ahnatal, near Cassel, Germany.

\section{Nonion commune (D'Orbigny) Cushman}

\section{Plate 3, figure 2}

Nonionina communis D'Orbigny, Foraminifères fossiles du bassin tertiaire de Vienne, p. 106, pl. 5, figs. 7, 8, 1846. Reuss, Deutsche geol. Gesell. Zeitschr., vol. 3, p. 155, 1851. Egger (part), Neues Jahrb., 1857, p. 298, pl. 14, figs. 11, 12(?) [not figs. 13-15].

Reuss, Akad. Wiss. Wien Sitzungsber., vol. 55, pt. 1, p. 106, 1867.

Karrer, Akad. Wiss. Wien Sitzungsber., vol. 58, pt. 1, p. 190, 1868.

Reuss, Akad. Wiss. Wien Sitzungsber., vol. 59, pt. 1, p. 465, 1869.

Terquem, Soc. géol. France Mém., sér. 3, vol. 1, p. 15, 1878.

Terrigi, Pont. accad. sci. Nuovi Lincei Atti, vol. 33, p. 96, pl. 4, figs. 75, 76, 1880; vol. 35, p. 205, pl. 4, fig. 51, 1883.

Rzehak, Naturf. Ver. Brünn Verh., vol. 14, pt. 1, p. 93, 1885.

Mariani, Soc. italiana sci. nat. Atti, vol. 31, p. 127, 1888.

Franzenau, Termes. Füzetek, vol. 17, p. 80, 1894.

Egger, Naturh. Ver. Passau Jahresber. 16, p. 40, pl. 3, figs. $17 \mathrm{a}, \mathrm{b}, 1895$.

Fornasini, Accad. sci. Ist. Bologna Mem., ser. 5, vol. 7, p. 8 (644), 1899.

Silvestri, Pont. accad. sci. Nuovi Lincei Mem., vol. 15, p. $335,1899$.

Allix, Feuille des jeunes naturalistes, vol. 43, p. 45, 1913.

Toula, K.-k. geol. Reichsanstalt Verh., 1914, p. 208; K.-k. geol. Reichsanstalt Jahrb., vol. 64, p. 660, 1914 [1915].

Clodius, Ver. Freunde Naturges. Mecklenburg Archiv, 75. Jahr., p. 144, 1922.

Paalzow, Offenbacher Ver. Naturkunde Ber., 1912-24, p. 27, pl. 2, figs. 13a, b, 1924.

Martinotti, R. ufficio geol. d'Italia Boll., vol. 51, no. 5, p. 4 (list), 1926.

Clodius, Mecklenburg. geol. Landesanstalt Mitt., vol. 39, p. 115 (table), 1930.

Test slightly longer than broad, compressed, umbilical region slightly depressed, filled with a granular mass of secondary material, periphery rounded; chambers distinct, slightly inflated, about 10 in adult coil, increasing in size as added; sutures distinct, slightly depressed, distinctly curved; wall smooth, except the granular umbilical area; aperture a low opening at the base of the apertural face. Length $0.60-0.70 \mathrm{~mm}$; breadth $0.40-0.45 \mathrm{~mm}$; thickness $0.25-0.28 \mathrm{~mm}$.

The types of this species are from the Miocene of Nussdorf, in the Vienna Basin of Austria. Our figured specimen is a topotype. D'Orbigny also records the species from the Pliocene of Coroncina, near Siena, Italy. The following are records for the species that seem to be worthy of listing, although they are for the 
most part unaccompanied by figures. Miocene, upper beds, Grinzing, Salzthon, Wieliczka, Austria; from the Leithakalk of Nussdorf; Miocene of Bordeaux, France; Pliocene clays of Siena and Astrupp, Italy, and living in the Adriatic. Upper Oligocene of Gaas, France (Reuss). Miocene, Bavaria, and older Pliocene of Monte Bartolomeo, Lake Garda, Italy (Egger). Miocene, Kostej, Banat region of Hungary (Karrer). Pliocene, Isle of Rhodes (Terquem). Pliocene, Italy (Terrigi). Miocene, Mahr-Ostrau, Austria (Rzehak). Pliocene of Savona, Italy (Mariani). Miocene, Hungary (Frazenau). Miocene, Italy (Fornasini). Pliocene, Siena, Italy (Silvestri). Miocene, France (Allix). Miocene, Ottnanager, Austria, and Hungary (Toula). Upper Miocene, Mecklenburg and Brömsenberg, near Lübtheen, Germany (Clodius). Oligocene, Offenbach, Germany (Paalzow). Pliocene, Orosei, Italy (Martinotti).

A few other records for this species are very questionable and are not listed here.

In our collections there are specimens that seem to be referable to this species from Imendorf, near Salzenburg, Austria ; Mollersdorf, Austria ; Gebel Murr, Egypt; Wadi Rieina, Egypt; and Habashi Bore, $30^{\circ} 18^{\prime} 30^{\prime \prime}$ north latitude, $32^{\circ} 31^{\prime} 45^{\prime \prime}$ east longitude, Egypt, the last three from material collected by Dr. W. A. Macfadyen.

The species seems close to $N$. elongata (D'Orbigny) but is slightly less compressed and has fewer chambers.

\section{Nonion elongatum (D'Orbigny) Cushman}

Plate 3, figures 4-6

Nonionina elongata D'Orbigny, Annales sci. nat., vol. 7, p. 294, no. $20,1826$.

Fornasini, Accad. sci. Ist. Bologna Mem., ser. 6, vol. 1, p. 12, pl. 3, figs. 4, 4a, 1904.

Test longer than broad, completely involute, biumbilicate, the umbilical regions filled with a finely papillate mass of secondary shell material, periphery broadly rounded; chambers distinct, numerous, 12 to 16 in the adult coil, increasing rather rapidly in breadth in the later portion, very slightly if at all inflated; sutures distinct, slightly if at all depressed, slightly curved; wall smooth except for the umbilical region, finely perforate; aperture a low, narrow arched opening at the base of the apertural face. Length $0.65-0.75 \mathrm{~mm}$; breadth $0.40-0.50 \mathrm{~mm}$; thickness $0.35 \mathrm{~mm}$.

The types of this species were from the Miocene of Dax, in France. Our figured specimens are topotypes. There are other specimens in our collections which seem to belong to this species from the Miocene of Kostej, Banat region, Hungary; Loos, near Baden, Austria; Baden, Austria; Brünn, Austria; and Wadi el Bir, Egypt; and from the Pliocene of Castel Arquato, Italy.

Specimens from the last-named locality are hardly to be distinguished from $N$. fabum (Fichtel and Moll), which has fewer chambers and less marked umbilical filling. The species also resembles $N$. boueanum (D'Orbigny) but has a rounded periphery, and the sutures are not prominently limbate.

\section{Nonion granosum (D'Orbigny) Cushman}

Plate 2, figures 17,18

Nonionina granosa D'Orbigny, Annales sci. nat., vol. 7, p. 294, no. 8, 1826; Foraminifères fossiles du bassin tertiaire de Vienne, p. 110, pl. 5, figs. 19, 20, 1846.

Seguenza, Accad. gioenia sci. nat. Atti, ser. 2 , vol. 18 , p. $15,1862$.

Reuss, Akad. Wiss. Wien Sitzungsber., vol. 50, pt. 1, p. 479, 1864.

Karrer, Akad. Wiss. Wien Sitzungsber., vol. 58, pt. 1, p. 190, 1868.

Terquem, Soc. géol. France Mem., sér. 3, vol. 1, p. 15, 1878.

Terrigi, Pont. accad. sci. Nuovi Lincei Atti, vol. 35, p. 206, pl. 4, fig. 54, 1883.

Hogius, Naturwiss. Ver. Osnabrück Jahrb. 1893-94, p. 179, 1895.

Fornasini, Accad. sci. Ist. Bologna Mem., ser. 5, vol. 7, p. 12 (648), 1899 ; vol. 8 , p. 44 , fig. 48 (in text), 1900 .

Liebus, K.-k. geol. Reichsanstalt Jahrb., vol. 52, p. 97, 1903.

Clodius, Ver. Freunde Naturges. Mecklenburg Archiv, 75. Jahr., p. 144, 1922.

Test close-coiled, nearly involute, somewhat compressed, very slightly depressed at the umbilical area, which is filled with a few comparatively large, raised bosses, the central one somewhat larger than the others, periphery broadly rounded; chambers distinct, 9 or 10 in the adult coil, of rather uniform size and shape, slightly if at all inflated; sutures very distinct, somewhat limbate, not depressed, very slightly curved; wall smooth, except for the umbilical area, very coarsely perforate; aperture a very narrow opening at the base of the apertural face. Diameter $0.45-0.55 \mathrm{~mm}$; thickness $0.25 \mathrm{~mm}$.

D'Orbigny recorded this species from the Pliocene of Castel Arquato in 1826 and from Nussdorf, in the Vienna Basin, in 1846, and also from the Pliocene of Coroncina, near Siena, Italy. It has since been recorded several times, as the references show, but has rarely been figured. The specimens here figured came from Nussdorf. The following are the published records: Pleistocene, Catania, Sicily (Seguenza); upper Oligocene, Germany (Reuss); Miocene, Kostej (Karrer); Pliocene, Isle of Rhodes (Terquem); Pliocene, marl of the Quirinal, Rome, Italy (Terrigi); upper Oligocene, Doberg, near Bünde, Germany (Hosius); Pliocene, Calabria, Sicily; and Recent Adriatic (Fornasini); and Oligocene of upper Bavaria (Liebus). As most of these records are not accompanied by figures, they must be open to question.

\section{Nonion lamarcki (D'Orbigny) Cushman}

Plate 3, figure 9; plate 6, figure 26

Nonionina lamarcki D'Orbigny, Annales sci. nat., vol. 7, p. 294, no. $13,1826$.

Fornasini, Accad. sci. Ist. Bologna Mem., ser. 6, vol. 1, p. 11, pl. 3, figs. 1, 1a, 1904. 
Test involute, compressed, periphery of early portion sharply angular, later somewhat rounded, umbilical region slightly depressed and filled with a granular mass of secondary shell material; chambers distinct, slightly if at all inflated, increasing gradually in size as added, of uniform shape; sutures distinct, curved, very slightly depressed, not distinctly limbate; wall smooth, finely perforate; aperture a low opening at the base of the apertural face. Length $0.80-0.90 \mathrm{~mm}$; bread th $0.65-0.70 \mathrm{~mm}$; thickness $0.30-0.35 \mathrm{~mm}$.

The types of this species are from the Miocene of Dax, France. The specimen here figured is a topotype. The species occurs also in our collections from the following Miocene localities of France: Burdigalien supérieur, Mérignac, Gironde; Point Gourguet, Saucats (Gironde); Burdigalien moyen, Le Coquillat, Léognan; Burdigalien inférieur, Moulin de l'église, Saucats, Gironde; Aquitanien supérieur, Saint Arit, near Mont de Marsan; Aquitanien inférieur, railroad cut, La Bréde; Helvétien, Moulin du Minoy, Salles.

The angled periphery seems to be a constant feature, though the figure copied from D'Orbigny's plate by Fornasini does not show it. This form is close to $N$. boueanum (D'Orbigny), which has somewhat limbate sutures. The two species are very close to one another.

\section{Nonion perforatum (D'Orbigny) Cushman}

Plate 3, figure 3

Nonionina perforata D'Orbigny, Foraminifères fossiles du bassin tertiaire de Vienne, p. 110, pl. 5, figs. 17, 18, 1846.

Reuss, Akad. Wiss. Wien Sitzungsber., vol. 55, pt. 1, p. 106, 1867.

Karrer, Akad. Wiss. Wien Sitzungsber., vol. 58, pt. 1, p. $190,1868$.

Terquem, Soc. géol. France Mém., sér. 3, vol. 1, p. 15, 1878.

Fornasini, Accad. sci. Ist. Bologna Mem., ser. 5, vol. 7, p. 15 (651), 1899.

Toula, K.-k. geol. Reichsanstalt Jahrb., vol. 64, p. 672, 1914 [1915].

Clodius, Ver. Freunde Naturges. Mecklenburg Archiv, 75. Jahr., p. 144, pl. 1, fig. 19, 1914 [1915].

Nonionina punctata D'Orbigny, Foraminifères fossiles du bassin tertiaire de Vienne, p. 111, pl. 5, figs. 21, 22, 1846.

Seguenza, Accad. gioenia sci. nat. Atti, ser. 2, vol. 18, p. 14, 1862; Akad. Wiss. Wien Sitzungsber., vol. 50, pt. 1, p. 479, 1864.

Terrigi, Pont. accad. sci. Nuovi Lincei Atti, vol. 35, p. 206, pl. 4, fig. 53, 1883.

Hosius, Naturwiss. Ver. Osnabrück Jahrb., 1893-94, p. $179,1895$.

Fornasini, Accad. sci. Ist. Bologna Mem., ser. 5, vol. 7, p. $16(652), 1899$.

Liebus, K.-k. geol. Reichsanstalt Jahrb., vol. 56, p. 361, 1960.

Test involute, compressed, umbilical region depressed and filled with a few small rounded bosses, periphery bro adly rounded; chambers distinct, slightly inflated, of rather uniform shape and size, 9 or 10 in the adult coil; sutures distinct, slightly depressed, curved, not limbate; wall smooth, coarsely perforate; aperture a low opening at the base of the apertural face. Diameter $0.50 \mathrm{~mm}$; thickness $0.20-0.25 \mathrm{~mm}$.
The types are from the Miocene of Nussdorf in the Vienna Basin. Our figure shows a topotype specimen.

A comparison of material seems to show that the two species described by D'Orbigny are apparently the same. There are numerous records from the upper Oligocene to the Pliocene of central and southern Europe, but as very few of the records are accompanied by figures it is difficult to be at all certain that they all represent this species.

\section{Nonion boueanum (D'Orbigny) Hada}

\section{Plate 3 , figures 7,8}

Nonionina boueana D'Orbigny, Foraminifères fossiles du bassin tertiaire de Vienne, p. 108, pl. 5, figs. 11, 12, 1846.

Reuss, Deutsche geol. Gesell. Zeitschr., vol. 3, p. 155, 1851; Akad. Wiss. Wien Sitzungsber., vol. 39, p. 210, 1860; vol. 42, pp. 357, 366, 1860; Acad. royale sci. Belgique Bull., sér. 2 , vol. 15 , p. 156 , pl. 3, figs. 47, 48, 1863; Akad. Wiss. Wien Sitzungsber., vol. 50, pt. 1, p. 479, 1864; Akad. Wiss. Wien Denkschr., vol. 25, p. 164, 1865.

Mariani, Soc. italiana sci. nat. Atti, vol. 31, p. 128, 1888.

Malagoli, Soc. nat. Modena Atti, ser. 3, vol. 8, p. 183, 1889.

Terrigi, Com. geol. italiana Mem., vol. 4, pt. 1, p. 110, pl. 4, fig. 17, 1891; R. accad. Lincei Atti, ser. 4, Mem., vol. 6, p. 119 , pl. 10, fig. $5,1893$.

Hosius, Naturh. Ver. preuss. Rheinlande u. Westfalens Verh., vol. 50, p. 133, 1893; Naturwiss. Ver. Osnabrück Jahrb., 1893-94, p. 179, 1895.

Silvestri, Pont. accad. sci. Nuovi Lincei Mem., vol. 15, p. $335,1899$.

Schubert, Deutscher naturwiss.- med. Ver. Böhmen "Lotos" Sitzungsber., no. 6, p. 26, 1899.

Fornasini, Accad. sci. Ist. Bologna Mem., ser. 5, vol. 7, p. 7 (643), 1899.

Schubert, Deutscher naturwiss.- med. Ver. Böhmen "Lotos" Sitzungsber. 1900, p. 98.

Toula, K.-k. geol. Reichsanstalt Jahrb., vol. 64, pp. 645, 660,1914 [1915].

Martinotti, Soc. geol. italiana Boll., vol. 34, p. 250, 1915.

Krumpholtz, Naturf. Ver. Brünn Verh., vol. 54, p. 138, 1916.

Liebus, Deutscher naturwiss.- med. Ver. Bohmen "Lotos" in Prag, vol. 72, p. 129, 1924.

Macfadyen, Egypt Geol. Survey, 1930, p. 104, pl. 4, figs. $16 \mathrm{a}, \mathrm{b}, 1931$.

? Nonion boueana Hada, Tohoku Imp. Univ. Sci. Rept., 4th ser., Biol., vol. 6, p. 117, text fig. 76, 1931.

Test much compressed, umbilical areas depressed and filled with granular or papillate secondary shell material, periphery subacute; chambers distinct, elongate, of rather uniform shape, but more elongate in the later portion, 15 or more in the adult coil, slightly inflated; sutures distinct, slightly depressed, strongly curved, limbate; wall smooth except for the umbilical area; aperture small, arched, at the base of the apertural face.

The types of this species came from the Miocene of Nussdorf, in the Vienna Basin. Our figured specimen is a topotype. The above references are fossil records for this species, and there are many more records for its occurrence in the present oceans. Some of the figures given are evidently not this species. There is considerable variation in the species, as shown in our figures. There are records for central and southern Europe from 
the upper Oligocene to the Pliocene which may represent this species, but those from other regions evidently do not, as may be seen from the figures given and comparison with specimens from these localities.

In our collections there are specimens referable to this species from the following localities: Miocene of Austria, Nussdorf, Vosslau, Gainfarm, Rausnitz, Niederleis, Perchtoldsdorf, Mollendorf, Nickolsburg, Holuluea, Loos, Baden; Miocene of Hungary, Kostej and Varpolata; Miocene of Egypt, Wadi Sudr, Wadi el Bir, near Gebel Gentoul; Pliocene of Italy, Castel Arquato, Paggiarone, near Siena.

\section{Nonion soldanii (D'Orbigny) Cushman}

Plate 3, figures 10,11 ; plate 4 , figure 23

Nonionina soldanii D'Orbigny, Foraminifères fossiles du bassin tertiaire de Vienne, p. 109, pl. 5, figs. 15, 16, 1846.

Reuss, Deutsche geol. Gesell. Zeitschr., vol. 3, p. 155, 1851.

Costa, Accad. pontaniana Atti, vol. 8, pt. 2, p. 201, pl. 17, fig. 11, 1856.

Reuss, Akad. Wiss. Wien Sitzungsber., vol. 39, p. 210, 1860; vol. 42 , p. 366,1860 .

Seguenza, Accad. gioenia sci. nat. Atti, ser. 2, vol. 18, p. 13, 1862.

Reuss, Akad. Wiss. Wien Sitzungsber., vol. 50, pt. 1, p. 479; 1864; Akad. Wiss. Wien Denkschr., vol. 55, pt. 1, p. 105, 1867.

Karrer, Akad. Wiss. Wien Sitzungsber., vol. 58, pt. 1, p. 189, 1868.

Terquem, Soc. géol. France Mém., sér. 3, vol. 1, p. 15, 1878.

Egger, Naturh. Ver. Passau Jahresber. 16, p. 40, pl. 3, figs. 16a, b, 18a, b, 1895 .

Fornasini, Accad. sci. Ist. Bologna Mem., ser. 5, vol. 7, p. 17 (653), 1899.

Liebus, K.-k. geol. Reichsanstalt Jahrb., vol. 52, p. 85, 1903.

Nonionina falx Czjzek, Haidinger's Naturwiss. Abh., vol. 2, p. 6 , pl. 12 , figs. $30,31,1848$.

Hosius, Naturh. Ver. preuss. Rheinlande u. Westfalens. Verh, vol. 50, p. 135, 1893.

Fornasini, Accad. sci. Ist. Bologna Mem., ser. 5, vol. 7, p. 11 (647), 1899.

Test close-coiled, biumbilicate, the umbilical area deeply excavated, periphery very broadly rounded, almost truncate; chambers distinct, not inflated, of uniform size and shape, increasing very slightly in size; sutures distinct, not depressed, slightly limbate, very slightly curved; wall smooth, usually rather coarsely perforate; aperture a low, broad opening at the base of the apertural face. Diameter $0.50 \cdots 0.60 \mathrm{~mm}$; thickness $0.30-0.35 \mathrm{~mm}$.

The types of this species came from the Miocene of Nussdorf, in the Vienna Basin. Our figured specimen is a topotype. D'Orbigny also recorded it from the Pliocene of Coroncina, near Siena, Italy. Czjzek's species $N$. falx is apparently the same.

The generic position of these forms with very deep umbilicus and coarsely perforate test is open to some doubt. They seem to be related to similar larger forms which probably should be included under Anomalina and are bilaterally symmetrical in the adult, derived from a trochoid ancestry. The whole group needs detailed study with sections and large series of specimens in all stages of development.

There are various records of the species in central and southern Europe from the upper Oligocene to the Pliocene.

Our collections contain specimens which seem to be this species from the following localities: Miocene of Austria, Nussdorf, Mollendorf (near Baden), Niederleis, Mollersdorf, Baden, Loos (near Baden), Brünn, Vosslau, Perchtoldsdorf, Rausnitz; from Hungary at Kostej and Varpolata. There are specimens also from Czjzek's localities at Paremba and Dombrard; from Egypt at Wadi Rieina and from a well near Ras el Ush; from near Zuffana, Sardinia. In the Pliocene there are specimens from Coroncina and Paggiarone, near Siena, Italy.

On plate 4 , figure 23 , are copies of the early figures given by Fornasini ${ }^{3}$ of D'Orbigny's 1826 unpublished plates of Nonionina melo. Whether this species is the same as that of the Vienna Basin monograph is very questionable. So far as the figure shows it is not umbilicate, and the number and shape of the chambers are very different.

\section{Nonion tuberculatum (D'Orbigny) Cushman}

Plate 3, figures 12, 16, 17

Nonionina tuberculata D'Orbigny, Foraminifères fossiles du bassin tertiaire de Vienne, p. 108, pl. 5, figs. 13, 14, 1846.

Reuss, Akad. Wiss. Wien Sitzungsber., vol. 50, pt. 1, p. 479, 1864.

Terrigi, Pont. accad. sci. Nuovi Lincei Atti, vol. 35, p. 207, 1883.

Malagoli, Soc. nat. Modena Atti, ser. 3, vol. 8, p. 183, 1889.

Fornasini, Accad. sci. Ist. Bologna Mem., ser. 5, vol. 7, p. 20 (656), 1899 .

Nonionina subgranosa Egger, Neues Jahrb., 1857, p. 299, pl. 14, figs. 16-18.

Test close-coiled, compressed, periphery broadly rounded, umbilical regions slightly depressed and filled with secondary shell material, the surface of which has numerous small rounded bosses; chambers distinct, slightly inflated, of rather uniform shape, increasing very gradually in size, 9 to 12 in the adult coil; sutures distinct, slightly depressed, curved; wall smooth except for the umbilical regions, coarsely perforate; aperture a small, low opening at the base of the apertural face. Diameter $0.35-0.40 \mathrm{~mm}$; thickness $0.15 \mathrm{~mm}$.

The types of this species came from the Miocene of Nussdorf, in the Vienna Basin. Our figured specimens are topotypes. The specimens figured from Ortenburg (figs. 16, 17) are practically topotypes of Egger's species, which seems to be a synonym.

The species has been recorded from the upper Oligocene, Miocene, and Pliocene of central and southern Europe.

Fornasini, C., Le Polistomelline fossili d'Italia: Accad sci. Ist. Bologna Mem., ser. 5, vol. 7, p. 14 (650), text fig. 3, 1899. 
Nonion dense-punctatum (Egger) Cushman

Plate 3, figure 15

Nonionina dense-punctata Egger, Neues Jahrb., 1857, p. 299, pl. 14, figs. 22, 23.

Nonion dense-punctatus Cushman, Soc. sci. Seine-et-Oise Bull., sér. 2 , vol. 9 , p. 50 , pl. 1, figs. $8 \mathrm{a}$, b, 1928 ,

Test nearly circular in side view, somewhat compressed, periphery broadly rounded, umbilical regions distinctly depressed; chambers distinct, somewhat inflated, about eight in the adult coil, of rather uniform size and shape; sutures distinct, somewhat depressed, slightly curved; wall very coarsely perforate, otherwise smooth; aperture a low opening at the base of the apertural face. Diameter up to $0.35 \mathrm{~mm}$; thickness 0.15 $\mathrm{mm}$.

The types of this species were described by Egger from the Miocene of Hausbach, in Bavaria. Our figured specimen is practically a topotype coming from Egger's locality of Ortenburg. I have also recorded the species from the upper Oligocene of Morigny, near Paris.

\section{Nonion pauper (Egger) Cushman \\ Plate 3, figure 13}

Nonionina pauper Egger, Neues Jahrb., 1857, p. 300, pl. 14, figs. $26,27$.

Nonionina testa suborbiculata angulata laevigata, compressa; loculis 5 convexis, marginem versus attenuatis; suturis parum profundis; apertura? Diam. $1 / 2 \mathrm{~mm}$.

Egger.

The above is a copy of the original description by

A copy of the original figure is given here. No specimens were found in our material from Ortenburg. The type locality is given by Egger as Miocene of Habühl, Bavaria.

\section{Nonion simplex (Karrer) Cushman}

Plate 4, figure 1

Nonionina simplex Karrer, Novara-Exped., Geol. Theil, vol. 1. pt. 2 , p. 83 , pl. 16 , fig. 17,1865 .

$N$. testa discoidali, convexa, subumbilicata, laevigata, margine rotundata, loculis 10-12 angustatis, ultimo supra semilunari sicut apertura. Diam. 1 millim., rarissima.

The above is the description given by Karrer, and the figure here given is copied from his original. It does not give a very clear idea of the species. The types came from the Miocene of New Zealand.

\section{Nonion leo (Karrer) Cushman}

Plate 4, figure 2

Nonionina leo Karrer, Akad. Wiss. Wien Sitzungsber., vol. 58, pt. 1, p. 190, pl. 5, fig. 8, 1868.

On plate 4 is a copy of the type figure given by Karrer. As the surface is largely eroded it is difficult to get a very clear idea of the species. The types came from the Miocene of Kostej, in the Banat region of Hungary. I have failed to find specimens in material examined from the type locality.

\section{Nonion inflatum (Schubert) Cushman}

Plate 4, figure 3

Nonionina turgida Williamson var. inflata Schubert, Deutschen naturwiss.-med. Ver. Böhmen "Lotos" Sitzungsber., 1900, p. 97 , pl. 2, fig. $6 \mathrm{a}, \mathrm{b}$.

This species, according to the figures, has the chambers increasing very rapidly as added, the last-formed one making up the entire surface in apertural view. The types are from the Miocene of central Europe. I have not had any material referable to it.

\section{Nonion extensum (Cushman) Cushman}

Plate 4, figure 4

Nonionina extensa Cushman, U. S. Geol. Survey Bull. 676, p. 69, pl. 25, figs. 4a, b, 1918.

Test longer than broad, compressed, periphery rounded, umbilical regions slightly depressed; chambers fairly distinct, about eight in the adult coil, rapidly increasing in size as added in the adult, not inflated; sutures fairly distinct, little if at all depressed, slightly curved; wall smooth, distinctly perforate; aperture a low curved opening at the base of the apertural face. Length $0.60 \mathrm{~mm}$; breadth $0.40 \mathrm{~mm}$; thickness $0.20 \mathrm{~mm}$.

The type of this species is from the Miocene Duplin marl of Mayesville, S. C.

It has been found in our material only from the type locality.

\section{Nonion glabrellum Cushman \\ Plate 3, figure 14}

Nonion glabrella Cushman, Florida Geol. Survey Bull. 4, p. 38, pl. 6, figs. 6a, b, 1930.

Cole, Florida Geol. Survey Bull. 6, p. 31, 1931.

Cushman and Ponton, Florida Geol. Survey Bull. 9, p. 69, 1932.

Cushman and Cahill, U. S. Geol. Survey Prof. Paper 175-A, p. 20, pl. 7, figs. 3a, b, 1933.

Test somewhat longer than broad, much compressed, umbilical regions slightly depressed, tending slightly to uncoil in the adult, periphery rounded; chambers distinct, inflated, six or seven in the adult coil, increasing rather rapidly in size as added; sutures distinct, depressed, somewhat limbate, nearly radial, very slightly curved; wall smooth, finely perforate; aperture a low curved opening at the base of the apertural face with sometimes a supplementary, rounded opening in the apertural face connected with the base. Length 0.30 $\mathrm{mm}$; breadth $0.20 \mathrm{~mm}$; thickness $0.10 \mathrm{~mm}$.

The types are from the Miocene Choctawhatchee formation of old Coes Mill, about 11/2 miles northwest of Hosford, Liberty County, Fla., in the Cancellaria zone of the Choctawhatchee. In the Alum Bluff group (lower and middle Miocene) it has occurred in the Cardium beds and middle zone of the Shoal River formation, in the Oak Grove sand, and in the Chipola formation. Cole has recorded it from the Pliocene of Florida. 
It is a very small but rather distinctive species of the Florida region but has not been recorded in the Miocene to the north.

\section{Nonion costiferum (Cushman) Cushman}

Plate 4, figure 5

Nonionina costifera Cushman, Cushman Lab. Foram. Research Contr., vol. 1, pt. 4, p. 90, pl. 13, figs. 2a-c, 1926; vol. 2, pt. 3 , p. $65,1926$.

Nonion costifera Cushman, Stewart, and Stewart, San Diego Soc. Nat. History Trans., vol. 6, p. 60, pl. 3, figs. 13a, b, 1930.

Cushman and Parker, Cushman Lab. Foram. Research Contr., vol. 7, p. 7, pl. 1, figs. 27a, b, 1931.

Cushman and Laiming, Jour. Paleontology, vol. 5, p. 104, pl. 11, figs. 9a, b, 1931.

Nonionina boueana Chapman [not D'Orbigny], California Acad. Sci. Proc., ser. 3 (Geology), vol. 1, p. 255, pl. 30, figs. 14, $14 a, 1900$.

Test somewhat longer than broad, compressed, periphery acute, almost keeled, umbilical regions depressed, apertural face heart-shaped or broadly triangular, flattened or slightly concave; chambers distinct, numerous, as many as 20 in the adult coil, of rather uniform size and shape, not inflated; sutures distinct, limbate, slightly raised, increasing in thickness and height toward the umbilicus, strongly curved; wall smooth except for the raised sutures, finely perforate; aperture a small, low, curved opening at the base of the apertural face. Length up to $1 \mathrm{~mm}$; breadth $0.60 \mathrm{~mm}$; thickness $0.35-0.40 \mathrm{~mm}$.

The types of this species came from the Miocene Monterey shale of San Luis Obispo County, Calif. It has also been recorded from the Miocene of Humboldt County; from the east side of San Joaquin Valley; and from Los Sauces Creek, Ventura County, Calif.

\section{Nonion incisum (Cushman) Cushman}

Plate 4, figure 6

Nonionina incisa Cushman, Cushman Lab. Foram. Research Contr., vol. 1, pt. 4, p. 90, pl. 13, figs. 13a-c, 1926; vol. 2, pt. 3, p. 65, 1926.

Nonion incisa Cushman, Stewart, and Stewart, San Diego Soc. Nat. History Trans., vol. 6, p. 60, 1930.

Cushman and Laiming, Jour. Paleontology, vol. 5, p. 104, pl. 11, figs. 10a, b, 1931.

Cushman and Parker, Cushman Lab. Foram. Research Contr., vol. 7, p. 7, pl. 1, figs. 26a, b, 1931.

Cushman and Cabill, U. S. Geol. Survey Prof. Paper 175-A, p. 20, pl. 7, figs. 4a, b, 1933.

Test longer than broad, periphery acute, somewhat compressed, umbilical regions depressed, apertural face generally heart-shaped, slightly convex; chambers distinct, later ones very slightly inflated, of rather uniform size and shape, increasing slightly in size in the adult, about 15 in the final coil; sutures distinct, slightly depressed, strongly curved; wall smooth, very finely perforate; aperture a low, curved opening at the base of the apertural face. Length $0.60-0.70 \mathrm{~mm}$; breadth $0.45-0.50 \mathrm{~mm}$; thickness $0.30-0.35 \mathrm{~mm}$.

$$
\text { 1819-39-2 }
$$

This species was originally described from the Miocene Monterey shale of San Luis Obispo County, Calif. It has also been recorded from the Miocene of Los Sauces Creek, Ventura County, and the east side of San Joaquin Valley, Calif.; and from the Pliocene of Humboldt County, Calif. It occurs also in the Miocene St. Marys formation of Virginia and in the Choptank formation of Maryland.

\section{Nonion medio-costatum (Cushman) Cushman}

Plate 4, figures 7, 8

Nonionina medio-costata Cushman, Cushman Lab. Foram. Research Contr., vol. 1, pt. 4, p. 89, pl. 13, figs. 1a-c, 1926; vol. 2, pt. 3, p. 65, 1926.

Test slightly longer than broad, periphery rounded to subacute, compressed, umbilical regions depressed, apertural face generally heart-shaped to oval; chambers distinct, numerous, 15 or more in the adult coil, very slightly if at all inflated, of rather uniform shape, increasing gradually in size in the last part of the adult coil; sutures distinct, slightly limbate, often slightly depressed, somewhat curved; wall with the areas between the sutures toward the umbilical region raised, otherwise smooth; aperture a low, curved opening at the base of the apertural face. Length $0.65 \mathrm{~mm}$; breadth $0.40 \mathrm{~mm}$; thickness $0.20-0.25 \mathrm{~mm}$.

The types of this species came from the Miocene Monterey shale of San Luis Obispo County, Calif. It has not been recorded elsewhere. The distinguishing character is the raised area between the sutures near the umbilical area.

\section{Nonion dollfusi Cushman}

Plate 4, figure 13

Nonion dollfusi Cushman, Cushman Lab. Foram. Research Contr., vol. 12, p. 65, pl. 12, figs. 4 a, b, 1936.

Test much compressed, with a large, flat, slightly raised umbo, periphery with a distinct, rounded keel, sharply set off from the rest of the test; chambers very distinct, numerous, 15 to 18 in the adult coil, of uniform shape, increasing very gradually in size; sutures very distinct, deeply depressed, slightly sigmoid in the adult; wall smooth except for the depressions of the sutures; aperture consisting of a few small pores at the base of the inner margin of the last-formed chamber. Length $1.00-1.15 \mathrm{~mm}$; breadth $0.90-1.00 \mathrm{~mm}$; thickness 0.40 $\mathrm{mm}$.

The types of this species came from the Miocene Burdigalien supérieur of Merignac, Gironde, France. In our collections it also occurs in material collected by Dr. Dollfus at the following localities: Burdigalien supérieur, Point Gourguet, Saucats, Gironde, France. Burdigalien moyen, Le Coquillat, Leognan, France. Aquitanien supérieur, Saint Arit, near Mont de Marsan, France. Aquitanien inférieur, railroad cut, La Bréde, Larriey, France. A single specimen very similar to this was found in Miocene material from "Pecten bank, near Loretto, Italy." 


\section{Nonion montereyanum Cushman and Galliher}

Plate 4, figure 9

Nonion montereyanum Cushman and Galliher, Cushman Lab. Foram. Research Contr., vol. 10, p. 24, pl. 4, figs. 6a, b, 1934.

Test somewhat asymmetrical, variable, slightly evolute, umbilical regions slightly depressed, periphery rounded, becoming more broadly so in the adult; chambers distinct, numerous, 12 to 14 in the adult coil, of rather uniform shape, increasing gradually in size and breadth as added, later ones usually much thickened laterally and becoming nearly circular in section; sutures distinct, very slightly depressed, strongly curved; aperture a low opening at the base of the apertural face. Diameter $0.55 \mathrm{~mm}$; thickness $0.25 \mathrm{~mm}$.

The types of this species came from the Miocene Monterey shale, on the East Fork of Canyon Segundo, 50 feet stratigraphically below a point $2 \mathrm{~mm}$ (on map) west and $3 \mathrm{~mm}$ (on map) north of intersection of longitude $121^{\circ} 50^{\prime}$ and north line of James Meadows tract, Monterey quadrangle, Calif.

This species is variable in the amount of asymmetry developed. On the ventral side the chambers often end in distinct points.

Nonion montereyanum Cushman and Galliher var. carmeloense Cushman and $G$ alliher

Plate 4, figure 10

Nonion montereyanum Cushman and Galliher var. carmeloensis Cushman and Galliher, Cushman Lab. Foram. Research Contr., vol. 10, p. 24, pl. 4, figs. 7a, b, 1934.

Variety differing from the typical in the much more compressed test, lack of inflation in the later portion of the whorl, and somewhat fewer and slightly higher chambers.

The types of the variety came from the same locality as the typical form.

Nonion pizarrense W. Berry var. multicameratum Cushman and Kleinpell

Plate 4, figure 11

Nonion pizarrensis W. Berry var. multicameratum Cushman and Kleinpell, Cushman Lab. Foram. Research Contr., vol. 10, p. 4, pl. 1, figs. 10a, b, 1934.

Variety differing from the typical form in the greater number of chambers and the more open umbilical region.

The types of the variety are from the Miocene Monterey shale 35 feet stratigraphically above the contact with quartz diorite as exposed in Coyote Canyon, on the north side of Carmel Valley, Calif.

Similar forms also occur with the typical species in the Miocene of Florida.

\section{Nonion dingdeni Cushman}

Plate 4, figure 12

Nonion dingdeni Cushman, Cushman Lab. Foram. Research Contr., vol. 12, p. 65, pl. 12, figs. 5a, b, 1936.

Test slightly longer than broad, somewhat compressed, periphery in early stages subacute or slightly keeled, later rounded, umbilical region slightly depressed; chambers distinct, about 10 in the last-formed coil, distinctly inflated toward the inner end, increasing rather rapidly in height in the last portion; sutures distinct, deeply depressed toward the umbilicus, curved; wall smooth except for the umbilical region, which is filled with granular secondary shell material; aperture very low, narrow, at the base of the inner margin of the last-formed chamber. Length $0.60 \mathrm{~mm}$; breadth $0.50 \mathrm{~mm}$; thickness $0.35 \mathrm{~mm}$.

The types of this species came from the Miocene of Dingden, Germany.

\section{Nonion novo-zealandicum Cushman}

Plate 3, figure 19

Nonion novo-zealandicum Cushman, Cushman Lab. Foram. Research Contr., vol. 12, p. 66, pl. 12, figs. 6a, b, 1936.

Test compressed, umbilical region deeply excavated, periphery broadly rounded; chambers distinct, very slightly inflated, of uniform shape, increasing very gradually in size as added; sutures distinct, strongly limbate, thickening strongly toward the umbilicus, slightly curved; wall smooth, coarsely perforate; aperture an elongate, low opening at the base of the inner margin of the last-formed chamber. Length 0.90 $\mathrm{mm}$; breadth $0.80 \mathrm{~mm}$; thickness $0.45 \mathrm{~mm}$.

The types of this species came from the Miocene of Motatura, New Zealand.

\section{Nonion stachei Cushman}

Plate 3, figure 18

Nonion stachei Cushman, Cushman Lab. Foram. Research Contr., vol. 12 , p. 66, pl. 12, figs. 7a, b, 1936.

Test slightly longer than broad, compressed, periphery subacute, umbilical region with an umbonate mass of granular secondary shell material; chambers distinct, numerous, 15 to 18 in the adult coil, slightly if at all inflated; sutures distinct, limbate, slightly curved, expanded and raised toward the umbilicus; wall smooth except for the central umbonate mass and slightly raised sutures; aperture small, low, at the base of the last-formed chamber. Length $0.80 \mathrm{~mm}$; breadth 0.70 $\mathrm{mm}$; thickness $0.30 \mathrm{~mm}$.

The types of this species came from the Miocene Shell bed, Target Gully, Oamaru, New Zealand. 


\section{Nonion victoriense Cushman}

Plate 4, figure 14

Nonion victoriense Cushman, Cushman Lab. Foram. Research Contr., vol. 12, p. 67, pl. 12, figs. 10a, b, 1936.

Test slightly longer than broad, strongly compressed, particularly toward the subacute periphery, umbilical region not depressed; chambers distinct, curved, of rather uniform shape, not inflated; sutures distinct, strongly curved, limbate, not depressed; wall smooth except for the umbilical region, which has numerous small, raised beads that also run across the base of the apertural face; aperture a series of small, rounded openings at the base of the inner margin of the lastformed chamber. Length $0.70 \mathrm{~mm}$; breadth $0.50 \mathrm{~mm}$; thickness $0.30 \mathrm{~mm}$.

The types of this species came from the lower Pliocene near Lake Bunga, eastern Victoria, Australia.

\section{Nonion nicobarense Cushman}

Plate 4, figure 16

Nonion nicobarensis Cushman, Cushman Lab. Foram. Research Contr., vol. 12, p. 67, pl. 12, figs. 9a, b, 1936.

Test slightly longer than broad, slightly umbilicate, periphery rounded; chambers distinct, 10 to 12 in the adult coil, of rather uniform shape, not inflated; sutures distinct, curved, strongly limbate, fusing in a ring about the umbilicus, not depressed; wall smooth, coarsely perforate; aperture a low, broad opening with a distinct lip, at the base of the inner margin of the last-formed chamber. Length $0.35 \mathrm{~mm}$; breadth $0.28 \mathrm{~mm}$; thickness $0.15 \mathrm{~mm}$.

The types of this species came from the Pliocene of Kar Nicobar.

\section{Nonion ibericum Cushman \\ Plate 4, figures 17,18}

Nonion ibericum Cushman, Cushman Lab. Foram. Research Contr., vol. 12, p. 68, pl. 12, figs. 12, 13, 1936.

Test small, slightly longer than broad, periphery rounded; umbilical area slightly depressed but filled with granular secondary shell material; chambers distinct, about 10 in the adult coil, of uniform shape, increasing slightly in size as added; sutures distinct, limbate, curved, sigmoid in the adult, slightly depressed; wall smooth, except for the granulation of the umbilical region; aperture a low, broad opening at the base of the inner margin of the last-formed chamber. Length $0.20 \mathrm{~mm}$; breadth $0.15 \mathrm{~mm}$; thickness $0.08 \mathrm{~mm}$.

The types of this species came from the Pleistocene of Malaga, Spain.

\section{Nonion schwageri Cushman}

Plate 4, figure 22

Nonion schwageri Cushman, Cushman Lab. Foram. Research Contr., vol. 12, p. 67, pl. 12, figs. 8a, b, 1936.
Test slightly compressed, umbilical region slightly depressed, periphery broadly rounded; chambers few, about eight in the adult coil, of uniform shape, increasing very slightly in size, very slightly if at all inflated, sutures distinct, slightly curved or irregularly sigmoid, slightly if at all depressed; wall smooth; aperture consisting of a row of small rounded openings at the base of the inner margin of the last-formed chamber. Length $0.25 \mathrm{~mm}$; breadth $0.22 \mathrm{~mm}$; thickness $0.17 \mathrm{~mm}$.

The types of this species came from the Pliocene of Kar Nicobar.

\section{Nonion angustum Cushman}

Plate 4, figure 25

Nonion angustum Cushman, Cushman Lab. Foram. Research Contr., vol. 12, p. 68, pl. 12, figs. 11a, b, 1936.

Test about as long as broad, umbilical region slightly depressed, periphery rounded; chambers distinct, about 12 in the adult coil, of uniform shape and increasing very gradually in size, slightly inflated; sutures distinct, slightly depressed, gently curved, slightly sigmoid in the last portion; wall smooth, distinctly perforate; aperture low, elongate, at the base of the inner margin of the last-formed chamber. Length $0.50 \mathrm{~mm}$; breadth $0.45 \mathrm{~mm}$; thickness $0.20 \mathrm{~mm}$.

The types of this species came from the Pliocene of Lanarka, Island of Cyprus.

\section{Nonion attenuatum (Costa) Cushman}

$$
\text { Plate 4, figure } 19
$$

Nonionina attenuata Costa, Accad. pontaniana Atti, vol. 7, pt. 2, p. 202, pl. 17, figs. 10a, b, 1856.

Fornasini, Accad. sci. Ist. Bologna Mem., ser. 5, vol. 7, p. 6 (642), 1899.

Costa described and figured this species from the Pliocene of Italy. The two references given seem to be all for this species. The figure that is copied on plate 4 shows a test which has many chambers, somewhat umbilicate, and the apertural face broadly elliptical. I have been unable to find in my material any specimens that could be identified with this species.

\section{Nonion nautiloideum (Costa) Cushman}

Plate 4, figure 20

Nonionina nautiloidea Costa, Accad. pontaniana Atti, vol. 7, p. 2, pl. 20, fig. 1, 1856.

Fornasini, Accad. sci. Ist. Bologna Mem., ser. 5, vol. 7, p. 14 (650), 1899.

A copy of Costa's figure is given on plate 4, but I have been unable to find the species in our Italian Pliocene material from which Costa described this species. 
Nonion polystoma (Costa) Cushman

Plate 4, figure 15

Nonionina polystoma Costa, Accad. pontaniana Atti, vol. 7, pt. 2, p. 206, pl. 14, figs. 10a, A, B, 1856.

Fornasini, Accad. sci. Ist. Bologna Mem., ser. 5, vol. 7, p. 15 (651), 1899.

As in the preceding species the original figure of Costa is here given, and no material has been found. Costa described this species from the Pliocene of Italy, and Fornasini records it also from the Miocene.

Nonion rude (Costa) Cushman

Plate 4, figure 21

Nonionina rudis Costa, Accad. pontaniana Atti, vol. 7, pt. 2, p. 205, pl. 20, figs 2a, b, 1856.

Fornasini, Accad. sci. Ist. Bologna Mem., ser. 5, vol. 7, p. $16(652), 1899$.

Costa described this species from the Pliocene of Italy, and Fornasini records it as common in the Pliocene of Terra d'Otranto and as rare in the Pliocene of Calabria and also in the Pleistocene of Catania. I have had material from the last two localities but have not been able to find the species.

\section{Nonion striolatum (Costa) Cushman \\ Plate 4, figure 24}

Nonionina striolata Costa, Accad. pontaniana Atti, vol. 7, pt. 2, p. 203, pl. 17, figs. 12a, b, 1856.

Fornasini, Accad. sci. Ist. Bologna Mem., ser. 5, vol. 7, p. 19 (655), 1899.

The only records for this species are from the Pliocene of Italy. From the name and figure the characteristic ornamentation of the test is that shown on our figure, which is copied from Costa. No material of the species have been available for study.

\section{Nonion buxovillanum (Andreae) Cushman}

Plate 5, figure 2

Nonionina buxovillana Andreae, Abh. geol. Specialkarte ElsassLothringen, vol. 2, pt. 3, p. 162, pl. 11, figs. 3a, b, 1884.

The figure here given is copied from the originals of Andreae. I have seen no material that might be referred to this species. The types came from the Oligocene of Alsace.

\section{Nonion belridgense Barbat and Johnson}

Plate 5, figure 1

Nonion belridgensis Barbat and Johnson, Jour. Paleontology, vol. 8, p. 11, pl. 1, figs. 8, 9, 1934.

Hedberg, Jour. Paleontology, vol. 11, p. 674, pl. 91, figs. $11 a, b, 1937$.

Test involute, bilaterally symmetrical, longer than broad, very slightly umbilicate, periphery acute; chambers numerous, 12 to 14 in last-formed coil; sutures slightly limbate in early portion, flush with surface near periphery, slightly depressed near umbilicus, curved, forming an acute angle with periphery; wall smooth, calcareous, finely perforate; apertural face heartshaped. Length $0.47 \mathrm{~mm}$, breadth $0.32 \mathrm{~mm}$, thickness $0.24 \mathrm{~mm}$.
The species differs from Nonion costiferum (Cushman) in the absence of limbate and costate sutures and fewer chambers. It has less depressed sutures and umbilici, a more acute periphery, and a broader apertural face than N. pizarrensis (W. Berry).

The types came from the upper part of the Reef Ridge shale (upper Miocene) of the Ohio Oil Co.'s well Bearstate No. 23, Belridge field, Kern County, Calif.

\section{Nonion formosum (Seguenza) Cushman}

Plate 5, figure 3

Nonionina formosa Seguenza, R. accad. Lincei Atti, ser. 3, vol. 6, p. 63, pl. 7, figs. 6, 6a, 1880.

Fornasini, Accad. sci. Ist. Bologna Mem., ser. 5, vol. 7, p. 12 (648), 1899.

The type figure is copied on plate 5 . The species is recorded from the late Tertiary of Italy, but no specimens that could be definitely identified with it have been available.

\section{Nonion? excavatum (Seguenza) Cushman}

Plate 5, figure 5

Nonionina excavata Seguenza, Accad. gioenia sci. nat. Atti, ser. 2, vol. 18, p. 14, pl. 1, figs. 4, 4a, 1862 .

Copies of the original figures of Seguenza are given on plate 5. His material came from the Pleistocene of Catania, Italy. Although the figures are evidently somewhat conventionalized, they suggest that the form may possibly belong to Elphidium. I have had no material referable to this species.

\section{Nonion subcarinatum (Seguenza) Cushman}

Plate 5, figure 4

Nonionina subcarinata Seguenza, Accad. gioenia sci. nat. Atti, ser. 2, vol. 18, p. 15, pl. 1, figs. 3, 3a, 1862.

Fornasini, Accad. sci. Ist. Bologna Mem., ser. 5, vol. 7, p. 19 (655), 1899.

Seguenza described and figured this species from the Pleistocene of Catania, Sicily, and Fornasini later recorded it as rare at the same locality and in the Pliocene of Calabria. The test is strongly umbonate, with limbate sutures and coarsely perforate. The original figures of Seguenza are copied on plate 5 .

This is not the same as D'Orbigny's "Nonionina subcarinata", described in 1839 , but not having seen the species I hesitate to give it a new name, as it may possibly be a synonym of some already described species.

Nonion? perfossum (Clodius) Cushman

Plate 5, figure 8

Nonionina perfossa Clodius, Ver. Freunde Naturges. Mecklenburg Archiv, 75. Jahr., p. 144, pl. 1, fig. 19, 1922.

The figure given for this species is reproduced here. It shows very little in the way of essential details. The species was described from the upper Miocene of Mecklenburg, Germany. 


\section{Nonion limbum (D'Orbigny) Cushman}

Plate 5, figure 6

Nonionina limba D'Orbigny, Annales sci. nat., vol. 7, p. 294, no. 14, Modèles, no. 11, 1826.

Parker, Jones, and H. B. Brady, Annals and Mag. Nat. History, ser. 3, vol. 16, p. 20, pl. 3, fig. 99, 1865.

Basset, Soc. sci. Charente-Inférieure Annales, 1884, pl. 163, fig., 1885.

Fornasini, Accad. sci. Ist. Bologna Mem., ser. 5, vol. 7 , p 13 (649), text fig. 2, 1899.

On plate 5 will be found a photograph of the 1826 model of D'Orbigny. The type came from the Pliocene of Castel Arquato, Italy, where it is recorded as rare. I have not been abis to find it in a considerable amount of material looked over from the type locality.

\section{Nonion galeatum Cushman}

Plate 5, figure 7

Nonion galeata Cushman, Cushman Lab. Foram. Research Contr., vol. 7, p. 28, pl. 4, figs. 7a, b, 1931; Bernice P. Bishop Mus. Bull. 119, p. 120, pl. 14, figs. 8a, b, 1934.

Test close-coiled, bilaterally symmetrical, somewhat compressed, the periphery very broadly rounded, sides deeply umbilicate; chambers 10 to 12 in number, distinct, slightly inflated, the inner end projecting into the central depression; sutures distinct, slightly depressed, very slightly curved; wall smooth except about the umbilical depression, where there are, in the early chambers, roughened areas at the inner part of each chamber; aperture broad and low, extending completely along the base of the final chamber, and with a slight lip, the sides of the chamber extending somewhat outward over the umbilical depression. Length 0.65 $\mathrm{mm}$; breadth $0.35 \mathrm{~mm}$.

This species is known only from the Pliocene of Fiji.

\section{Elphidium ezoense Asano}

Plate 20, figures 5, 6

Elphidium ezoense Asano, Geol. Soc. Japan Jour., vol. 44, no. 527 , p. 787 , pl. 24 (12), figs. 1, 2, text figs. 1, 2, 1937.

Test comparatively large, compressed, diameter about 4 times thickness, periphery rounded, usually lobulated, umbilical region strongly umbonate, much raised with a large boss of clear shell material; chambers as many as 20 in last-formed coil; later chambers slightly inflated with wavy periphery, earlier ones not inflated and entire along periphery; sutures gently curved, depressed, retral processes numerous and short, somewhat indistinct in the earlier ones; wall thick; aperture consisting of a low broad opening at base of apertural face, occasionally with circular pores on central portion of apertural face. Length up to 2.2 $\mathrm{mm}$; breadth ca. $0.6 \mathrm{~mm}$.

The types are from the Pliocene of Zarigawa, Numata, Uryû-gun, Hokkaidô. The species occurs at other Japanese Pliocene localities. It is closely allied to $E$. oregonense Cushman and Grant.

\footnotetext{
3a The description of Elphidium ezoense Asano should stand on page 65 of this report, just before the description of Elphidium translucens Natland.
}

\section{Nonion pompilioides (Fichtel and Moll) Cushman}

Plate 5, figures 9-12

"Nautilus melo" Soldani, Testaceographica, p. 38, pl. 8, figs. zz, A, B, C, 1798.

Nautilus pompilioides Fichtel and Moll, Testacea microscopica, p. 31, pl. 2, figs. a-c, 1798 .

Nonionina pompilioides D'Orbigny, Annales sci. nat., vol. 7, p. 294, no. $15,1826$.

Terrigi, Pont. accad. sci. Nuovi Lincei Atti, vol. 35, p. 204, pl. 4, fig. 49, 1883.

H. B. Brady, Challenger Rept., Zoology, vol. 9, p. 727, pl. 109, figs. 10, 11, 1884.

Cushman, U. S. Nat. Mus. Bull. 71, pt. 4, p. 25, pl. 17, figs. 2a, b, 1914; Bull. 100, vol. 4, p. 366, 1921.

Nonion pompilioides Cushman, U. S. Nat. Mus. Bull. 104, pt. 7, p. 4, pl. 1, figs. 7-11; pl. 2, figs. 1, 2, 1929.

Galloway and Morrey, Bull. Am. Paleontology, vol. 15, p. 43, pl. 6, figs. 15a, b, 1929.

Cushman, Cushman Lab. Foram. Research Contr., vol. 5, p. 89, pl. 13, figs. 25a, b, 1929.

Cushman and Cole, Cushman Lab. Foram. Research Contr., vol. 6 , p. 95 , pl. 13 , figs. $4 a, b, 1930$.

Cole, Florida Geol. Survey Bull. 6, p. 32, pl. 6, fig. 2, 1931.

Hadley, Bull. Am. Paleontology, vol. 20, no. 70-A, p. 14, pl. 2, figs. 1, 2, 1934.

Melonis etruscus Montfort, Conchyliologie systématique, vol. 1, p. $67,17^{\mathrm{e}}$ genre, 1808 .

Polystomclla etrusca Defrance, Dictionnaire des sciences naturelles, vol. 32 , p. $183,1824$.

Nonionina umbilicatula D'Orbigny, Annales sci. nat., vol. 7, p. 293, pl. 15, figs. 10-12, Modèles, no. 86, 1826.

Test planispiral, bilaterally symmetrical, entirely involute, umbilici deeply excavated, periphery very broadly rounded, not lobulate; chambers 8 to 10 in the adult coil, of uniform shape, increasing slowly in size as added, not inflated; sutures not depressed, limbate, fusing along the umbilicus to form a slightly thickened ring, but not raised; wall smooth, coarsely perforate; aperture low, at the base of the broad, low apertural face. Diameter $0.35-0.50 \mathrm{~mm}$; thickness $0.25-0.40 \mathrm{~mm}$.

Fichtel and Moll described this species from recent material from the Mediterranean and also recorded it from the Pliocene of Coroncina, near Siena, Italy. It has been recorded from many parts of the ocean and as fossil in the later Tertiary of southern Europe and of the Atlantic and Pacific coasts of America.

The sutures are more limbate than in $N$. soldanii. Both species are subject to considerable variation in the relative thickness of the test.

\section{Nonion incrassatum (Fichtel and Moll) Montfort}

\section{Plate 5, figure 13}

Nautilus incrassatus Fichtel and Moll, Testacea microscopica, p. 38, pl. 4, figs. a-c, 1798.

Nonion incrassatus Montfort, Conchyliologie systématique, vol. 1, p. $211,53^{\mathrm{e}}$ genre, 1808.

Heron-Allen and Earland, Discovery Repts., vol. 4, p. 434, pl. 16, figs. 5, 6, 1932 .

Nonionina incrassata D'Orbigny, Annales sci. nat., vol. 7, p. 293, no. 6, 1826.

Terrigi, Pont. accad. sci. Nuovi Lincei Atti, vol. 35, p. 205, pl. 4, fig. 52, 1883. 
Fornasini, Accad. sci. Ist. Bologna Mem., ser. 5, vol. 7, p. $12(648), 1899$.

Test close-coiled, somewhat compressed, with large and prominent umbones, periphery rounded, slightly lobulated; chambers distinct, somewhat inflated, 10 to 12 in the adult coil, increasing very gradually in size as added; sutures distinct, depressed, slightly curved; wall smooth; aperture in the median line at the base of the apertural face, arched.

Fichtel and Moll had this species from "Portus Ferrarius", in the island of Elba. It has been recorded from the Pliocene of Rome by Terrigi and Fornasini, and Heron-Allen and Earland record it from off the Falkland Islands. The original figures of Fichtel and Moll are copied here.

\section{Nonion asterizans (Fichtel and MolI) Cushman}

\section{Plate 5, figures 14-17}

Nautilus asterizans Fichtel and Moll, Testacea microscopica, p. 37, pl. 3, figs. e-h, 1798.

Nonionina asterizans Terrigi, Pont. accad. sci. Nuovi Lincei Atti, vol. 33, p. 95, pl. 4, fig. 78, 1880.

Nonion asterizans Cushman, U. S. Nat. Mus. Bull. 104, pt. 7, p. 6, pl. 2, figs. $5-7,1930$.

Nonionina communis Terrigi [not D'Orbigny], Pont. accad. sci. Nuovi Lincei Atti, vol. 35, p. 205, pl. 4, fig. 51, 1883.

Test planispiral, bilaterally symmetrical, completely involute or very slightly evolute, periphery angular, umbilici depressed, often with a few very small beads; chambers numerous, usually about 12 in the lastformed coil, broad and low, of uniform shape throughout; sutures distinct, depressed, usually somewhat limbate, the broadest part toward the inner end, thence thinning toward the periphery, evenly curved; wall smooth except for the umbilical region, which occasionally has a few small beads, finely perforate; apertural face convex, in peripheral view with the sides convex, aperture itself at the base of the face next to the previous coil, short and narrow or sometimes rounded.

The types of this species came from Rimini, on the Adriatic. I collected material at this locality, and the specimen on plate 5 , figure 17 , is a topotype. There are a few small beads near the umbilicus, but the inner ends of the chambers are somewhat raised, and the sutures there are broader and depressed. This gives the stellate appearance to that part of the test which is apparently the source of the appearance in Fichtel and Moll's figure and also the basis for their specific name.

The species is close to $N$. boueanum (D'Orbigny) but does not have as definitely limbate sutures nor so large an umbonate mass of secondary shell material. The figures in the Challenger report referred by Brady to this species represent a very different species. As many later authors have followed the Challenger figures it is difficult to place their material without seeing the original.
The species has a much sharper periphery than $N$. scapha (Fichtel and Moll). N. asterizans occurs mainly in the Mediterranean and in the Indo-Pacific.

\section{Nonion scapha (Fichtel and Moll) Cushman}

Plate 5, figures 18-21

Nautilus scapha Fichtel and Moll, Testacea microscopica, p. 105, pl. 19, figs. d-f, 1798.

Nonionina scapha H. B. Brady, Nat. History Trans. Northumberland and Durham, vol. 1, p. 106, pl. 12, figs. 10a, b, 1865 [1867].

Terrigi, Pont. accad. sci. Nuovi Lincei Atti, vol. 35, p. 202, pl. 4, fig. 47, 1883.

H. B. Brady, Challenger Rept., Zoology, vol. 9, p. 730, pl. 109, figs. 14, 15, 16(?), 1884.

Terrigi, R. accad. Lincei Atti, ser. 4, Mem., vol. 6, p. 120, pl. 10, fig. 7, 1893.

Goës. K. svenska vetensk akad. Handl., vol. 25, no. 9 p.104, pl. 17, fig. 830 (part) (?), 1894.

Cushman, Carnegie Inst. Washington Pub. 342, p. 47, pl. 16, fig. 1, 1924.

Nonion scaphum Cushman, U. S. Nat. Mus. Bull. 104, pt. 7, p. 5 , pl. 2, figs. 3, 4, 1930 .

Nautilus faba Fichtel and Moll, Testacea microscopica, p. 103, pl. 19, figs. a-c, 1798.

Test planispiral, bilaterally symmetrical, somewhat evolute, periphery rounded, whole test compressed, umbilici depressed, unornamented; chambers numerous, averaging about 12 in the last-formed coil, later ones, as they tend to become evolute, broadening on the proximal end, the outline of the periphery somewhat less curved, and the chambers slightly more inflated; sutures distinct, depressed, not limbate; wall smooth, finely perforate; aperture a small opening at the base of the apertural face next to the preceding coil.

The two forms described by Fichtel and Moll as Nautilus scapha and $N$. faba seem to represent the same species. The types were from the Adriatic at Rimini and recorded as fossil in the Siena region, etc.

There are many records for this species, most of which are without figures. Until these records can be checked with actual material they must be left in some uncertainty. This is true also of many of the fossil records.

\section{Nonion depressulum (Walker and Jacob) Cushman}

Plate 5, figures 22-25

"Nautilus spiralis utrinque subumbilicatulus . . ." Walker and Boys, Testacea mineralogica, p. 19, pl. 3, fig. 68, 1784.

Nautilus depressulus Walker and Jacob, in Adams' Essays, Kanmacher's ed., p. 641, pl. 14, fig. 33, 1798.

Nonionina depressula Heron-Allen and Earland, Linnean Soc. London Trans., ser. 2, vol. 11, p. 279, pl. 43, figs. 4-7, 1916.

Nonion depressulum (Walker and Jacob), Cushman, U. S. Nat. Mus. Bull. 104, pt. 7, p. 3, pl. 1, figs. 3-6, 1930.

The following notes were given in the last reference (1930):

There are a great many records given for this species. It was described from Reculver, on the north coast of Kent, England. 
The type figure, which is copied here [pl. 5, fig. 22], shows a form with many low, elongate, curved chambers with a small, central umbilical area. There are very few figures indeed of this species although the number of references is large. Brady's Challenger figures do not at all fit this form but seem near to $N$. umbilicatulum. Of the figures given, those of Heron-Allen and Earland quoted above and copied here [pl. 5, figs. 23-25] seem to come the nearest to the originals, but these have fewer and broader chambers. Such forms are certainly abundant about the British Isles and the adjacent coast of Europe, and it seems that the name should be restricted to this form. The periphery is rounded, the sides slightly concave, sutures slightly limbate and much curved, chambers about 10 in number, which is several fewer than in the type figure.

\section{Nonion depressulum (Walker and Jacob) var. matagordanum Kornfeld}

Plate 5, figure 26

Nonion depressulum (Walker and Jacob) var. matagordanum Kornfeld, Stanford Univ., Dept. Geology, Contr., vol. 1, no. 3, p. 87, pl. 13, figs. $2 \mathrm{a}, \mathrm{b}, 1931$.

Test nearly circular in side view, 8 to 9 chambers in the lastformed whorl, in apertural view with parallel sides and broadly rounded angles, narrow, slightly longer than wide; very slightly if at all depressed at the umbilicus; chambers somewhat inflated and the sutures correspondingly depressed, forming a lobulated periphery; umbilical regions with a slight tendency toward filling in of shell tissue and a slight trace of stellate extension of this material along the sutures; wall smooth, finely punctate; aperture a narrow arched slit at the base of the apertural face. Diameter, 0.23 to $0.27 \mathrm{~mm}$.; thickness, $0.11 \mathrm{~mm}$.

The types of this species are Recent, from Matagorda County, Tex., south of the Gulf (Big Hill) salt dome. It is also recorded from the Miocene and later formations in wells in Texas and Louisiana.

\section{Nonion? umbilicatulum (Walker and Jacob) Cushman}

Plate 5, figure 27

"Nautilus spiralis umbilicatus sulcatis" Walker and Boys, Testacea mineralogica, p. 19, pl. 3, fig. 69, 1784 .

Nautilus umbilicatulus Walker and Jacob, Adams' Essays, Kanmacher's ed., p. 641, pl. 14, fig. 34, 1798.

Nonion? umbilicatulum Cushman, U. S. Nat. Mus. Bull. 104, pt. 7, p. 2, pl. 1, figs. 1a, b, 1930.

In the last reference cited above the following notes were given in regard to this species:

A reproduction of the original figure is given here. There is much uncertainty regarding this species. As will be seen by the figures, the two sides are evidently not the same. Parker and Jones commented on this figure as follows: "Figure 69 is a common form of Truncatulina lobatula, having the outline of the cells uniform or flush; the septal lines being merely 'furrowed.' According to Walker, it was from Sandwich-not common."

Montagu (Test. Brit. Suppl., p. 78) refers to this figure when describing a little Nonionina; and Williamson (Monogr., p. 42), makes it a Polystomella. We believe that they must both be wrong, because in the specimen figured by Walker the two faces are decidedly unsymmetrical.

If the Boys specimens are preserved, it would be a simple matter to straighten out this tangle, but until such time as this is done there is much uncertainty as to the species. In this connection it is enlightening to note Montagu's comments on the Walker and Jacob figures (copied from Boys), as he had at that time both the original specimens and drawings. "Indeed, we perceive so considerable a difference between the original drawings *** and the engravings taken from them that we would scarce have known them to be the same, had they not been marked with the same numbers."

The numerous references to this species accompanied by figures will be found in the synonymy under other names.

\section{Nonion? crassulum (Walker and Jacob) Cushman}

Plate 5, figure 29

"Nautilus spiralis crassus utrinque umbilicatus geniculis lineatis" Walker and Boys, Testacea mineralogica, p. 20, pl. 3, fig. 70, 1784.

Nautilus crassulus Walker and Jacob, in Adams' Essays, Kanmacher's ed., p. 641, pl. 14, fig. 35, 1798.

Nonion? crassulum Cushman, U. S. Nat. Mus. Bull. 104, pt. 7, p. 3, pl. 1, figs. 2a, b, 1930 .

This species described from Reculver, on the north coast of Kent, England, has been little referred to, and the original figure leaves much to be desired. If the types are extant, it may be possible to establish this species on a firm basis. Williamson has referred a form to it which is evidently not at all the same. The original figure is copied here.

The above notes cannot be much expanded until the types of this species are studied.

\section{Nonion elypticum (D'Orbigny) Cushman}

Plate 5, figure 28

Nonionina elyptica D'Orbigny, Annales sci. nat., vol. 7, p. 294, no. $16,1826$.

Nonionina elliptica Fornasini, Accad. sci. Ist. Bologna Mem., ser. 6a, vol. 1, p. 11, pl. 3, figs. 2, 2a, 1904.

The figures from D'Orbigny's "Planches inédites" as given by Fornasini are copied on plate 5. D'Orbigny gave no description of this species, simply the locality, Madagascar.

\section{Nonion grateloupi (D'Orbigny) Cushman}

\section{Plate 6, figures 1-7}

Nonionina grateloupi D'Orbigny, Annales sci. nat., vol. 7, p. 294, no. 19, 1826; in De la Sagra, Historia fisica, política y natural de la isla de Cuba, Foraminifères, p. 46, pl. 6, figs. $6,7,1839$.

Fornasini, Accad. sci. Ist. Bologna Mem., ser. 6, vol. 1, p. 12, pl. 3, fig. 5, 1904 .

Cushman, Carnegie Inst. Washington Pub. 291, p. 48, 1919; U. S. Nat. Mus. Proc., vol. 59, p. 61, pl. 14, figs. 9-11, 1921; Carnegie Inst. Washington Pub. 311, p. 55, pl. 9, figs. 7, 8, 1922; Pub. 344, p. 79, 1926.

Nonion grateloupi Cushman, U. S. Nat. Mus. Bull. 104, pt. 7, p. 10, pl. 3, figs. 9-11; pl. 4, figs. 1-4, 1930; Florida Geol. Survey Bull. 4, p. 36, pl. 6, figs. 1-3, 1930.

Cushman and Valentine, Stanford Univ., Dept. Geology, Contr., vol. 1, no. 1, p. 20, pl. 5, figs. 9a, b, 1930.

Cushman and Parker, U. S. Nat. Mus. Proc., vol. 80, art. 3, p. 10, pl. 2, figs. $6 a, b, 1931$.

Cole, Florida Geol. Survey Bull. 6, p. 32, pl. 7, figs. 7, 8, 1931.

Cushman and Ponton, Florida Geol. Survey Bull. 9, p. 68, 1932. 
Heron-Allen and Earland, Discovery Repts., vol. 4, p. 437, pl. 16, figs. 9, 10, 1932.

Earland, Discovery Repts., vol. 7, p. 131, 1933.

Cushman, U. S. Nat. Mus. Bull. 161, pt. 2, p. 43, pl. 10, figs. 8a-c, 1933 .

Cushman and Cahill, U. S. Geol. Survey Prof. Paper 175-A, p. 20, pl. 7, figs. 1a, b, 1933.

Bermúdez, Soc. cubana historia nat. Mem., vol. 9, p. 185, 1935.

Hadley, Elisha Mitchell Sci. Soc. Jour., vol. 52, no. 1, p. $35,1936$.

Nonionina punctulata D'Orbigny, Voyage dans l'Amérique méridionale, vol. 5, p. 28, pl. 5, figs. 21, 22, 1839.

Test planispiral, bilaterally symmetrical, mostly involute, in peripheral view the sides nearly parallel, periphery rounded; chambers numerous, usually 10 to 12 in the last-formed coil in adults, chambers increasing rapidly in length, especially in the last few chambers; sutures distinct, slightly depressed; wall smooth, finely perforate; aperture small, at the base of the lastformed chamber, narrow. Length, up to $0.60 \mathrm{~mm}$; breadth, $0.35 \mathrm{~mm}$; thickness, $0.22 \mathrm{~mm}$.

D'Orbigny originally noted this species from the Miocene of Dax, France. Later he described and figured a species under the same name from shore sands of Cuba, Jamaica, and Martinique. I have recorded it from Montego Bay, on the north coast of Jamaica, from numerous stations about the Tortugas, and from San Juan Harbor, Puerto Rico. It also occurred at a few Albatross stations in the Gulf of Mexico. Bermúdez records it from the coast of Cuba. It also occurs off the coast of California, the coast of Brazil, and southward to the Falkland Islands.

As a fossil it occurs in the Pleistocene and Pliocene of Florida. In the Miocene it occurs in Cuba, Santo Domingo, and Panama. Along the eastern Atlantic Coastal Plain it occurs in the Miocene Choctawhatchee, Shoal River, Oak Grove, and Chipola formations of Florida, the Choptank and Calvert formations of Maryland, and the Yorktown formation of Virginia.

\section{Nonion politum (D'Orbigny) Cushman}

Plate 5, figure 30

Nonionina polita D'Orbigny, Annales sci. nat., vol. 7, p. 294, no. $12,1826$.

Fornasini, Accad. sci. Ist. Bologna Mem., ser. 5a, vol. 10, p. 5, fig. 1 (in text), 1902.

D'Orbigny gave no description of this species, in 1826 simply giving the locality, Rimini on the Adriatic. It was figured in 1902 in the publication of the "Planches inédites." A copy of D'Orbigny's figure is given on plate 5, a drawing of a specimen I obtained at Rimini which almost exactly fits the figure. It is possible that this may be a definite species in the Mediterranean.

\section{Nonion laevigatum (D'Orbigny) Cushman}

Plate 6, figure 8

Nonionina laevigata D'Orbigny, Annales sci. nat., vol. 7, p. 293 , no. 3,1826 .
Guérin-Menéville's Cuvier, Iconographie, Mollusques, p. 9, pl. 2, fig. 7, 1829-43.

Fornasini, Accad. sci. Ist. Bologna Mem., ser. 5a, vol. 7, p. 13 (649), text fig. 1, 1899; vol. 8, p. 43, fig. 47 (in text), 1900 ; vol. 10 , p. $65,1902$.

No description of this species was given by D'Orbigny, but the locality was given as Rimini, on the Adriatic. The figure given by Fornasini shows that the earlier figure in Cuvier was also undoubtedly from D'Orbigny's original unpublished plate. I found no material referable to this in my collections from that locality. The figure on plate 6 is copied from Fornasini.

\section{Nonion germanicum (Ehrenberg) Cushman}

Plate 5, figures 31, 32

Nonionina germanica Ehrenberg, K. preuss. Akad. Wiss. Abh., p. 133, pl. 2, figs. 1a-g, 1839; Taylor's Sci. Mem., vol. 3, p. 357 , pl. 6, figs. 1a-g, 1843.

Nonion germanicum Cushman, U. S. Nat. Mus. Bull. 104, pt. 7, p. 8, pl. 3, figs. 4, 5, 1930.

Nonionina crassula Williamson [not Walker and Jacob], Recent Foraminifera of Great Britain, p. 33, pl. 3, figs. 70, 71, 1858.

Test close-coiled, completely involute, planispiral, bilaterally symmetrical, periphery rounded; about nine chambers in the last-formed coil, distinct, of uniform size and shape; sutures very slightly if at all depressed, slightly limbate and thickened toward the umbilical region, which is filled; wall smooth, distinctly but finely perforate; aperture a narrow slit at the base of the apertural face. Diameter usually less than $0.50 \mathrm{~mm}$; thickness about $0.18 \mathrm{~mm}$.

This is a very common species in the North Sea and about the British Isles, well figured by Williamson. It is somewhat difficult to place earlier records without figures, but the species has probably been recorded from this area. It is very close to the species of Elphidium from the same area, such as is referred to by HeronAllen and Earland in their report from the west of Scotland as Polystomella faba. It is apparently not found on the west side of the Atlantic.

\section{Nonion sloanii (D’Orbigny) Cushman}

Plate 6, figures 9, 10

Nonionina sloanii D'Orbigny, in De la Sagra, Historia física, política y natural de la isla de Cuba, Foraminifères, p. 68, pl. 6, figs. 18, 18 bis, 1839 .

Cushman, Carnegie Inst. Washington Pub. 291, p. 48, 1919; Pub. 344, p. 79, 1926.

Nonion sloanii Cushman, U. S. Nat. Mus. Bull. 104, pt. 7, p. 9, pl. 3, figs. 6-8, 1930.

Cushman and Cole, Cushman Lab. Foram. Research Contr., vol. 6, p. 96, pl. 13, figs. 5a, b, 1930.

Heron-Allen and Earland, Discovery Repts., vol. 4, p. 436, pl. 16, figs. 7, 8, 1932 .

Earland, Discovery Repts., vol. 7, p. 131, 1933.

Test elongate, about one and one-half times as long as broad, moderately compressed, periphery rounded, becoming more angled in later portion, umbilical regions 
somewhat depressed; chambers distinct, slightly inflated, 8 to 10 in the final coil, increasing rather rapidly in length in the final development; sutures distinct, slightly depressed, gently curved; wall smooth, the umbilical region sometimes with a slight roughening; aperture low, at the base of the apertural face. Length $0.25-0.30 \mathrm{~mm}$; breadth $0.15-0.18 \mathrm{~mm}$; thickness 0.12 $\mathrm{mm}$.

D'Orbigny described this species from shore sands of Jamaica. It occurs in the West Indian region and apparently southward to the Falkland Islands. As a fossil it occurs in the late Tertiary from the gorge of the Yumuri River, Matanzas, Cuba, and from Bluff 2, Cercado de Mao, Santo Domingo. A very similar form also occurs in the Pleistocene (Talbot formation) of Wailes Bluff, Md.

The species that occurs with $N$. grateloupi has fewer chambers, is less compressed, and tends to be somewhat angled.

\section{Nonion barleeanum (Williamson) Cushman}

Plate 6, figure 11

Nonionina barleeana Williamson, Recent Foraminifera of Great Britain, p. 32, pl. 3, figs. 68, 69, 1858.

Nonion barleeanum Cushman, U. S. Nat. Mus. Bull. 104, pt. 7, p. 11, pl. 4, fig. 5, 1930.

Test planispiral, bilaterally symmetrical, much compressed; periphery rounded, umbilici depressed and open; chambers numerous, 12 or more in the last-formed coil, of rather uniform shape and size; sutures curved, slightly limbate, not depressed; wall smooth, coarsely perforate; aperture semicircular, at the base of the apertural face. Diameter slightly less than $0.65 \mathrm{~mm}$; thickness, $0.18 \mathrm{~mm}$.

Williamson's specimens came from Skye, Stornoway, Shetlands, and Scarborough. Such forms have been recorded from about the British Isles as Nonionina umbilicatula, but with the great uncertainty existing in regard to that species, it seems best to use Williamson's name for this cold-water form.

As will be seen by the figure, this species is very close to the form described by D'Orbigny and figured here as N. politum.

\section{Nonion subcarinatum (D'Orbigny) Cushman}

\section{Plate 6, figure 12}

Nonionina subcarinata D'Orbigny, Voyage dans l'Amérique méridionale, vol. 5, Foraminifères, p. 28, pl. 5, figs. 23, 24, 1839.

D'Orbigny's figures are copied on plate 6 . The specimens came from the Falkland Islands. There seem to be no further records for this species.

\section{Nonion labradoricum (Dawson) Cushman}

Plate 6, figures 13-16

Nonionina labradorica Dawson, Canadian Naturalist, vol. 5, p. 191, fig. 4, 1860 .
Jones, Parker, and H. B. Brady, Crag Foraminifera, Palaeont. Soc., Pub., vol. 19, pl. 2, figs. 44, 45, 1866.

Woodward, The Observer, vol. 4, p. 201, 1893.

Nonionina scapha (Fichtel and Moll) var. labradorica Dawson, Canadian Naturalist, new ser., vol. 5, p. 177, fig. 5, 1870; Am. Jour. Sci., 3d ser., vol. 1, p. 206, fig. 5, 1871; Annals and Mag. Nat. History, ser. 4, vol. 7, p. 86, fig. 5, 1871; Canadian Naturalist, vol. 6, p. 255, pl. 3, fig. 4, 1872.

Nonion labradorica Cushman, Scripps Inst. Oceanography Bull., Tech. ser., vol. 1, p. 148, pl. 2, figs. 7, 8, 1927; U. S. Nat. Mus. Bull. 104, pt. 7, p. 11, pl. 4, figs. 6-12, 1930; Cushman Lab. Foram. Research Special Pub. 5, pl. 23, figs. 2a, b, 1933.

Blake, Biological survey of the Mount Desert region, pt. 5, p. 76, 1933.

Cushman and Kleinpell, Cushman Lab. Foram. Research Contr., vol. 10, p. 4, pl. 1, figs. 8a, b, 1934.

Cushman, Geol. Soc. America Bull., vol. 47, p. 431, 1936. Nonionina scapha Morton [not Fichtel and Moll], Portland Soc. Nat. History Proc., vol. 2, p. 121, pl. 1, figs. 23a, b, 1897.

Test small, planispiral, completely involute, bilaterally symmetrical, periphery bluntly angled, apertural face very broadly triangular, the sides convex; chambers few, rapidly increasing in size as added; sutures distinct, curved, very slightly if at all depressed, not limbate; wall thin, finely perforate; aperture a narrow slit at the base of the apertural face. Length, $0.50 \mathrm{~mm}$; breadth, $0.30 \mathrm{~mm}$; thickness, $0.30 \mathrm{~mm}$.

The range of this form shows it to be a decidedly Arctic species. Dawson's types came from the Gulf of St. Lawrence. It is recorded by Woodward from Labrador; Bank of Newfoundland; Murray Bay, Gulf of St. Lawrence; St. Pierre; Scatari; Cape Camille, northeast Anticosti; Cape St. Nicholas; and Gaspé Bay. Blake records it from Mount Desert. I have had specimens from the coast of New England and the deep cold water south of Cape Cod. It occurs in the late Tertiary clays of Georges Bank, and very similar specimens were found in the late Tertiary of the California region.

\section{Nonion orbiculare (H. B. Brady) Cushman}

Plate 6, figures 17-19

Nonionina orbicularis H. B. Brady, Annals and Mag. Nat. History, ser. 5, vol. 8, p. 415, pl. 21, figs. 5a, b, 1881; Akad. Wiss. Wien, Denkschr., vol. 43, p. 17, pl. 2, figs. 5a, b, 1881; Challenger Rept., Zoology, vol. 9, p. 727, pl. 109 , figs. 20, 21, 1884 .

Heron-Allen and Earland, Linnean Soc. London Trans., ser. 2, vol. 11, p. 280, 1916.

Cushman, Canadian Biology Contr., p. 13, 1921 [1922].

Pratje, Wiss. Meeresuntersuch., Abt. Helgoland, vol. 18, no. 6, p. 103 (list), 1931.

Nonion orbiculare Cushman, U. S. Nat. Mus. Bull. 104, pt. 7, p. 12, pl. 5, figs. 1-3, 1930.

Earland, Discovery Repts., vol. 7, p. 130, 1933.

Macfadyen, Geol. Mag., vol. 69, pl. 34, figs. 14a, b, 1932.

Test planispiral, bilaterally symmetrical, completely involute, periphery very broadly rounded; chambers 10 to 12 in the last-formed coil, distinct, not inflated, of uniform shape; sutures distinct, slightly depressed, slightly limbate toward the proximal end, 
wall very finely perforate, smooth; aperture a long, very narrow slit at the base of the apertural face, sometimes divided into several openings. Diameter, $0.75 \mathrm{~mm}$; thickness, $0.50 \mathrm{~mm}$.

This species, described from the Arctic off Nova Zembla, has occurred typically in Hudson Bay and is recorded by Heron-Allen and Earland off the west coast of Scotland. Brady in the Challenger report gives the following localities: West coast of Nova Zembla, 55 fathoms; shores of Spitsbergen, 7 fathoms; Faroe Channel, 632 fathoms; west coast of Scotland, 25 fathoms; and off Valentia, 112 fathoms. He also records it fossil from a post-Tertiary clay on the coast of Fifeshire. Macfadyen records it from the Pleistocene and Pliocene of East Anglia in Great Britain.

There are records from warmer areas that are evidently not this species, which is a characteristic one of cold waters.

The aperture tends toward that of Elphidium, and some specimens show what may be slight traces of retral processes.

\section{Nonion? exponens (H. B. Brady, Parker and Jones) Cushman}

\section{Plate 6, figure 20}

Nonionina exponens H. B. Brady, Parker and Jones, Zool. Soc. London Trans., vol. 12, p. 230, pl. 43, fig. 16, 1888.

Nonion? exponens Cushman, U. S. Nat. Mus. Bull. 104, pt. 7, p. 13, pl. 5, fig. 6, 1930.

Test free, equilateral, planospiral; lateral faces convex or somewhat flattened, peripheral edge rounded; composed of from 2 to 3 convolutions; all more or less visible on both sides of the shell, the final whorl consisting of about 7 or 8 segments; margin entire; septa marked by fine lines, without superficial depressions. Diameter one one-hundredth of an inch $(0.25 \mathrm{~mm})$.

A form somewhat allied to $N$. depressula but differing from the species in its evolute mode of growth, its even sutures and noninflated segments.

This species was described and figured by the authors from a depth of 940 fathoms off the Abrolhos Bank, off Brazil. Its position as a Nonion seems doubtful, but it is included here for the record.

Nonion pauperatum (Balkwill and Wright) Cushman

Plate 6, figures 21-23

Nonionina pauperata Balkwill and Wright, Royal Irish Acad. Trans., vol. 28, Sci., p. 353, pl. 13, figs. 25, 26, 1885.

Halkyard, Manchester Micr. Soc. Trans., p. 71, pl. 2, fig. $13,1889$.

Chaster, Southport Soc. Nat. Sei. First Rept., 1890-91, p. 66, 1892.

Wright, Royal Irish Acad. Proc., ser. 3, vol. 1, p. 493, 1891; Irish Naturalist, vol. 9, p. 55, 1900.

Earland, Quekett Micr. Club Jour., ser. 2, vol. 9, p. 230, 1905.

Millett, Recent Foraminifera of Galway, p. 7, 1908.

Heron-Allen and Earland, Royal Micr. Soc. Jour., p. 342, pl. 11, figs. 16, 17, 1911; Royal Irish Acad. Proc., vol. 31, pt. 64, p. 144, 1913; Linnean Soc. London Trans., ser. 2, vol. 11, p. 281, 1916; British Antarctic Exped., Zoology, vol. 6, p. 228, 1922; Linnean Soc. London Jour., Zoology, vol. 35, p. 640, 1924; Royal Micr. Soc. Jour., vol. 50, p. 192,1930 .
Nonion pauperatum Cushman, U. S. Nat. Mus. Bull. 104, pt. 7, p. 13, pl. 5, figs. 4, 5, 7, 1930 .

Heron-Allen and Earland, Discovery Repts., vol. 4, p. 437, 1932.

Test planispiral, bilaterally symmetrical, involute, periphery angular; chambers about nine in the lastformed coil, of uniform shape and relative size, slightly inflated; sutures distinct, slightly depressed, limbate toward the proximal end, the umbilicus filled and confluent with the sutures; wall distinctly perforate, smooth; aperture a low opening at the base of the apertural face.

There are numerous records for this species about the British Isles, the following among them: Off Dublin coast (Balkwill and Wright); off Jersey (Halkyard); off Southport, England, rare in shore gatherings and shallow water (Chaster); southwest of Ireland, 53 and 345 fathoms; Dogs Bay, very rare (Wright); Bognor, Sussex, rare (Earland); Galway, very rare (Millett); Selsey Bill, Sussex; Clare Island region of Ireland; west of Scotland (Heron-Allen and Earland). Wright also records it from the Pleistocene of the north of Ireland. Heron-Allen and Earland have recorded the species from the Plymouth region, England, from the Antarctic, and from Lord Howe Island, in the Pacific. No figures accompany the records, however. They also record it from the Miocene of Australia.

This is very much like $N$. germanicum and may be only a slightly broader form of the same species.

\section{Nonion pizarrense W. Berry}

Plate 6, figure 27

Nonion pizarrensis W. Berry, Jour. Paleontology, vol. 1, p. 269, text figs. I (1-3), 1928.

Cushman and Kellett, U. S. Nat. Mus. Proc., vol. 75, art. 25 , p. 4, pl. 1, figs. 10a, b; pl. 2, figs. 1a, b, 1929 .

Cushman, Florida Geol. Survey Bull. 4, p. 37, pl. 6, figs. 7, 8, 1930.

Cushman and Ponton, Florida Geol. Survey Bull. 9, p. 69, 1932.

Cushman and Cahill, U. S. Geol. Survey Prof. Paper 175-A, p. 20, pl. 7, figs. 2a, b, 1933.

Cushman and Kleinpell, Cushman Lab. Foram. Research Contr., vol. 10, p. 4, pl. 1, figs. 9a, b, 1934.

Nonionina depressula Cushman [not Walker and Jacob], U. S. Nat. Mus. Bull. 103, p. 72, pl. 25, figs. 5a, b, 1918.

Nonionina boueana Cushman [not D'Orbigny], U. S. Geol. Survey Bull. 676, p. 68, pl. 25, fig. 3, 1918.

Test slightly longer than broad, nearly bilaterally symmetrical, periphery broadly rounded, umbilieal regions depressed but not open; chambers distinct, 12 to 15 in the adult coil, of uniform shape, increasing gradually in size, somewhat inflated; sutures distinct, somewhat depressed, gently curved; wall smooth, polished, except the umbilical region, which is often roughened, very finely perforate; aperture a low opening at the base of the apertural face, often tending to become slightly asymmetrical. Length up to $0.60 \mathrm{~mm}$; breadth $0.45-0.50 \mathrm{~mm}$; thickness $0.22-0.25 \mathrm{~mm}$. 
The types came from 8 fathoms of water at the mouth of the Tumbez River, at Puerto Pizarro, Peru. The species has occurred also in Recent material from Payta and Pimentel, Peru. It has been found in the Miocene of the Gatun formation, in the Miocene of California, and in the Miocene of the Atlantic Coastal Plain in the Choctawhatchee, Shoal River, and Chipola formations of Florida, the St. Marys and Calvert formations of Maryland, and the Yorktown formation of Virginia.

The species shows some variation, particularly in the relative amount of asymmetry, tending toward Nonionella.

\section{Nonion pizarrense W. Berry var. basispinatum Cushman and Moyer}

Plate 6, figure 28

Nonion pizarrensis W. Berry var. basispinata Cushman and Moyer, Cushman Lab. Foram. Research Contr., vol. 6, p. 54, pl. 7, figs. $18 \mathrm{a}, \mathrm{b}, 1930$.

Variety differing from the typical form in the later chambers, which on the outer margin toward the base have a fringe of small spinose processes often very conspicuous also along the sutures.

The types of the variety came from depths of 35 to 50 fathoms off San Pedro, Calif.

\section{Nonion boueanum (D'Orbigny) var. armatum (H. B. Brady) Cushman}

Plate 6, figure 24

Nonionina boueana D'Orbigny var. armala H. B. Brady, Challenger Rept., Zoology, vol. 9, p. 730, pl. 115, figs. 9a, b, 1884.

IIeron-Allen and Earland, Zool. Soc. London Trans., vol. 20, p. $732,1915$.

'The test of this variety has the periphery at the inner end of the adult coil with short, truncated spines, the earlier ones with two spines to a chamber, then a single one, and the later chambers smooth.

The types of the variety came from shore sands on the east coast of Madagascar. Heron-Allen and Earland record it from the Kerimba Archipelago, off the southeastern coast of Africa.

\section{Nonion subturgidum (Cushman) Cushman}

Plate 6, figure 29

Nonionina sublurgida Cushman, Carnegie Inst. Washington Pub. 342, p. 47, pl. 16, fig. 2, 1924.

Nonion subturgidum Cushman, U. S. Nat. Mus. Bull. 161, pt. 2, p. 43 , pl. 10, figs. $4-7,1933$.

Test bilaterally symmetrical, compressed, last-formed coil composed of eight or nine chambers, greatly increasing in length as added, the last-formed one extending the entire length of the test; periphery rounded; sutures very slightly depressed, distinct; apertural face broadly rounded, umbilical area often filled with secondary material; aperture at the base of the last-formed chamber at the median line. Length, up to $0.65 \mathrm{~mm}$; breadth, $0.45-0.5 \mathrm{~mm}$; thickness, $0.16-0.25 \mathrm{~mm}$.

This is a fairly common species in shallow water of the South Pacific.

The types of the species came from Samoa. Specimens have been recorded from off Nairai, Fiji, in 12 fathoms; from Viva Anchorage, Fiji, in 3 fathoms; and from off Rotonga.

The relative width of the apertural face and the amount of involution of the last-formed chambers are somewhat variable.

\section{Nonion pacificum (Cushman) Cushman}

Plate 6, figure 25

Nonionina umbilicatula (Montagu) var. pacifica Cushman, Carnegie Inst. Washington Pub. 342, p. 48, pl. 16, fig. 3, 1924.

Nonion umbilicatulum (Montagu) var. pacificum Cushman, Scripps Inst. Oceanography Bull,, Tech. ser., vol. 1, no. 10 , p. 49 , pl. 2 , fig. $5,1927$.

Nonion pacificum Cushman, U. S. Nat. Mus. Bull. 161, pt. 2, p. 44, pl. 10, figs. 9a, b, 1933; Bernice P. Bishop Mus. Bull. 119, p. 120, pl. 14, figs. 7a, b, 1934.

Test much compressed, entirely involute, slightly umbilicate, periphery rounded; chambers distinct, usually about eight in the last-formed coil, not inflated; sutures distinct, not limbate, very slightly curved; wall smooth, finely and evenly perforate; aperture an elongate, narrow slit, at the base of the apertural face. Length, $0.6 \mathrm{~mm}$; breadth, $0.5 \mathrm{~mm}$; thickness, $0.3 \mathrm{~mm}$.

Our figure shows the holotype from Samoa. The species is common in deeper water in the South Pacific. A table of 17 stations is given in Bulletin 161, part 2, with a range in depth from 189 to 2,776 fathoms. There is some variation in the degree of compression of the test, in the depth of the umbilici, and in the fineness of the perforations of the test.

The following species were originally described as Nonionina but are not given on the preceding pages:

Nonionina bulloides D'Orbigny, Annales sci. nat., vol. 7, no. 2, p. 293, 1826 (=Pullenia).

N. sphaeroides D'Orbigny, idem, no. 1, p. 293; Modèles, no. 33 (=Pullenia).

N. umbilicata D'Orbigny, idem, no. 5, p. 293; Modèles, no. 86 (=Planorbulina).

N. erythraea Ehrenberg, K. preuss. Akad. Wiss. Abh., p. 132, 1838 (=?).

N. brownii D'Orbigny, in De la Sagra, Historia física, política y natural de la isla de Cuba, Foraminifères, p. 45, pl. 7, figs. 22, 23, 1839. (See Cushmanella brownii (D'Orbigny).)

$N$. canariensis D'Orbigny, in Barker-Webb and Berthelot, Histoire naturelle des îles Canaries, vol. 2, pt. 2, Foraminifères, p. 128, pl. 2, figs. 33, 34, 1839 (=Haplophragmoides).

N. pelagica D'Orbigny, Voyage dans l'Amérique méridionale, vol. 5, pt. 5, Foraminifères, p. 27, pl. 3, figs. 13, 14, 1839 (=Hastigerina).

$N$. arctica Ehrenberg, K. preuss. Akad. Wiss. Abh., p. 427, 1841 $(=?)$.

$N$. integra Ehrenberg, idem, p. $427(=?)$.

N. millepora Ehrenberg, idem, p. 427, pl. 3, figs, vii, 50 (=?). 
N. globosa Von Hagenow, Neues Jahrb., 1842, p. 574 (=Discorbis?).

N. acervata Ehrenberg, K. preuss. Akad. Wiss. Ber., p. 167, $1843(=?)$.

$N$. gravinensis Nicolucci, Nuovi annali sci. nat. Bologna, ser. 2 vol. 6, p. 200, 1846 (=?).

N. striatula Nicolucci, idem, p. $200(==$ ?).

N. splendida Boll, Geogn. deutsch. Ostseeländer, p. 177, pl. 2, fig. 15,1846 (=?).

$N$. heteropora Ehrenberg, K. preuss. Akad. Wiss. Ber., p. 485, 1847 (=?).

N. neglecta Michelotti, Natuurk. Verh. holland. Maatsch. Wetensch. Haarlem, ser. 2, vol. 3, pt. 2, p. 15, 1847 (=?).

$N$. inflata Alth, Haidinger's Naturwiss. Abh., vol. 3, pt. 2, p. 266, pl. 13, fig. 22, 1850 (=?).

N. magdenburgica Philippi, Palaeontographica, vol. 1, p. 81, pl. $\mathrm{x} a$, fig. 21a, 1851 (=?).

N. placenta Reuss, Deutsche geol. Gesell. Zeitschr., vol. 3, p. 72, pl. 15, fig. 33, 1851 (=Haplophragmoides?).

N. quaternaria Reuss, Haidinger's Naturwiss. Abh., vol. 4, pt. 1, p. 34, pl. 2, fig. 13, 1851 (=Pullenia).

N. quinqueloba Reuss, Deutsche geol. Gesell. Zeitschr., vol. 3, p. 71, pl. 5, fig. 31, 1851 (=Pullenia).

N. astreae Ehrenberg, Mikrogeologie, pl. 25, figs. ii, B. 8, 1854 $(=?)$.

N. hemprichii Ehrenberg, idem, pl. 23, fig. 37 (=?).

N. ocellata Ehrenberg, idem, pl. 27, fig. 37 (=Robulus?).

N. spira Ehrenberg, idem, pl. 30, fig. 32 (=Robulus?).

N. bavarica Ehrenberg, K. preuss. Akad. Wiss. Abh., p. 163, pl. 3, figs. i-iv, 1855 (=?).

N. helicina Costa, Accad. sci. Napoli Mem., vol. 2, p. 123, pl. 1, figs. $18 \mathrm{~A}-\mathrm{C}, 1855[1857](=$ ?).

N. latidorsata Bornemann, Deutsche geol. Gesell. Zeitschr., vol. 7, p. 339, pl. 16, fig. 4, 1855 (=Haplophragmoides).

N. obliqua Costa, Accad. pontaniana Atti, vol. 7, pt. 2, p. 204, $1856(=?)$.

$N$. ornata Costa, idem, p. 203, pl. 17, figs. ii, $17 \mathrm{~A}-\mathrm{C}$ (=Cibicides).

N. silicea Schultze, in Müllers Archiv, 1856, p. 171, pl. 6B, figs. 4-7 (= Haplophragmoides?).

N. archetypus Ehrenberg, K. preuss. Akad. Wiss. Monatsber., 1858 , pp. 310 , 337 , pl. 1 , fig. $13(=?)$.

$N$. fusca Ehrenberg, idem, p. 23 (=?).

$N$. graeca Ehrenberg, idem, p. $23(=?)$.

$N$. jeffreysii Williamson, On the Recent Foraminifera of Great Britain, p. 34, pl. 3, figs. 72, 73, Royal Soc. London, 1858 (= Haplophragmoides?)

N. globulus Eichwald, Lethaea rossica, vol. 1, p. 350, pl. 22, figs. $17 \mathrm{a}-\mathrm{c}, 1860$ (=Endothyra?).

$N$. rotula Eichwald, idem, p. 349, pl. 22, figs. 18a-c (=Endothyra?).

$N$. borealis Ehrenberg, K. preuss. Akad. Wiss. Monatsber., p. 306, 1861 (= ?).

N. bathyomphala Reuss, Akad. Wiss. Wien Sitzungsber., vol. 46, pt. 1, p. 95, pl. 13, figs. 1a, b, 1862 [1863] (= Anomalina?).

$N$. escheri Kaufmann, ìn Heer, Urwelt Schweiz, p. 198, fig. 110, 1865 (= Globigerina?).

N. globulosa Ehrenberg, op. cit., 1862, p. 198, fig. 111 (= ?).

$N$. jaccardi De Loriol, Soc. phys. et histoire nat. Genève Mém., vol. 18 , pt. 1, p. 106, pl. 3, fig. 19, $1865(=$ ?)

$N$. villeroensis De Loriol, idem, p. 107, pl. 3, fig. 20 ( $=$ ?).

$N$. compacta Kübler and Zwingli, Neujahrsblatt Burgersbibl. Winterthur, p. 18, pl. 3, fig. 17, 1866 (= Planorbulina?).

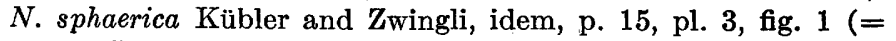
Globigerina?).

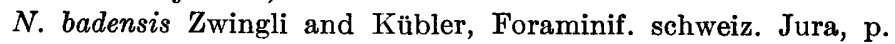
37, pl. 4, pt. 2, fig. 3, 1870 (= Planorbulina?).

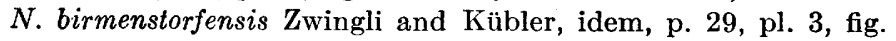
39 (= Planorbulina?).
N. oblonga Kübler and Zwingli, idem, p. 21, pl. 1, pt. 4, fig. 14 (= Planorbulina?).

$N$. turgida Williamson. (See Nonionella turgida (Williamson). N. aglajae Ehrenberg, K. preuss. Akad. Wiss. Abh. 1872, pl. 4, fig. $3,1873(=$ ?).

$N$. floridana Ehrenberg, idem, pl. 5, fig. 1 (= ?).

N. crisiae Ehrenberg, K. preuss. Akad. Wiss. Monatsber., 1872, p. 285 (= ?).

N. crystallina Ehrenberg, idem, p. 285 (=?).

N. fiustrella Ehrenberg, idem, p. $286(=$ ?).

N. hyalina Ehrenberg, idem, p. 286 (= ?).

$N$. koldeweyi Ehrenberg, idem, p. 286 (=?).

N. nympharum Ehrenberg, idem, p. 286 (=?).

N. spirillina Ehrenberg, idem, p. 286 (=?).

N. quatriloba Seguenza, R. accad. Lincei Atti, ser. 3, vol. 6, pl. 17, fig. 15, 1880 (= ?).

$N$. boueana var. janiformis Jones. (See Nonionella janiformis (Jones).)

N. cretacea Schlumberger, Soc. géol. France Bull., sér. 3, vol. 27 , p. 460 , pl. 8 , fig. 1 ; pl. 11 , figs. $21,22,1899$ (= Camerina?).

N. scapha var. bradii Chapman, Rept. British Antarctic Exped., Geology, vol. 2 (1916), p. 71, pl. 5, fig. 42, 1917 (= Nonionella?).

N. turgida var. arenacea Heron-Allen and Earland, British Antarctic Exped., Zoology, vol. 6, no. 2, p. 228, pl. 7, figs. 36-38, 1922 (= Trochammina?).

N. clarki Hanna, California Univ., Dept. Geol. Sci., Bull., vol. 14, p. 324, pl. 59, fig. 2, 1923 (= Cyclammina?).

\section{Genus NONIONELLA Cushman, 1926}

Nonionella Cushman, Cushman Lab. Foram. Research Contr., vol. 2, p. 64, 1926; Cushman Lab. Foram. Research Special Pub. 1, p. 205, 1928; U. S. Nat. Mus. Bull. 104 pt. 7, p. 14, 1930; Cushman Lab. Foram. Research Special Pub. 4, p. 193, 1933; U. S. Nat. Mus. Bull. 161, pt. 2, p. 45,1933 .

Nonionina (part) of authors.

Genoholotype, Nonionella miocenica Cushman.

Test subtrochoid, the dorsal side only partly involute, ventral side completely so, close-coiled; chambers, especially in the adult, inequilateral, the ventral side developing a distinct, elongate lobe at the umbilical end, which covers the umbilicus itself; wall calcareous, finely perforate; aperture at the base of the apertural face of the chamber low and elongate, extending from the peripheral border toward the ventral side. Cretaceous to Recent.

The subtrochoid forms belonging to this genus are close to Nonion, and the microspheric form may be very close to it in many species. In the megalospheric form there is a tendency to adopt the adult character at an earlier stage, and it is in this form that the trochoid character usually becomes most marked. The genus is known as far back as the Cretaceous. Some of the older fossil species are as trochoid as Recent ones. The genus seems to be most at home in fairly cool waters and in the temperate zones, although there are a few species in warmer waters.

Some of the species show but little of the trochoid development; others are very strongly trochoid. The earliest species are distinctly trochoid. 
Since this manuscript was completed a new generic name, Pseudononion, has been proposed by Asano ${ }^{4}$ with the new species $P$. japonicum Asano as the genoholotype. Apparently it is to include those species which on the ventral side do not have the elongate lobe at the umbilicus. I have not seen the type species and have here placed it under Nonionella until further study is possible.

\section{Nonionella austinana Cushman \\ Plate 7, figures 1, 2}

Nonionella austinana Cushman, Cushman Lab. Foram. Research Contr., vol. 9, p. 57, pl. 7, figs. 2a-c, 1933.

Test small, nearly as broad as long, dorsal side flattened or slightly concave in the center, ventral side convex, periphery broadly rounded; chambers distinct, few, six in the last-formed whorl, increasing regularly in size as added; sutures distinct, slightly curved, very slightly depressed; wall smooth, finely perforate; aperture a low elongate slit, at the base of the inner margin of the last-formed chamber on the ventral side. Length $0.25 \mathrm{~mm}$; breadth $0.18 \mathrm{~mm}$; thickness $0.12 \mathrm{~mm}$.

This is a small but distinctive species distinguished from Nonionella cretacea by the much more rounded form, very highly rounded periphery, and fewer chambers, of which there are only six in a whorl. N. cretacea has as many as 10 chambers in a whorl, is much more elongate, and has the periphery narrow. From Nonionella robusta Plummer, characteristic of the Navarro group, $N$. austinana is distinguished by the more broadly rounded periphery and the fewer chambers in a whorl, $N$. robusta having typically about eight chambers and $N$. austinana only six.

This species is most abundant in the Austin chalk but occurs also in the basal Taylor and in the Selma chalk.

Taylor marl: Southeast of Del Valle, Travis County, Tex.; Honey Grove-Landonia Highway, 10.8 miles south of Honey Grove, Fannin County, Tex.; 5.3 miles west of intersection of Medina Lake road and Zarzamore Avenue, San Antonio, Bexar County, Tex.; Castroville road 0.35 mile east of Medio Creek Bridge, Bexar County, Tex.; Greenville road 3.9 miles east of Farmersville, Collin County, Tex.

Selma chalk: Sardis-Henderson road $1 \frac{11}{2}$ miles west of Sardis, Henderson County, Tenn.

Austin chalk: Ditch 1.4 miles north of Melissa Tex., on Sherman-McKinney Highway; road cut between two railroad underpasses at north edge of Howe, Grayson County, Tex., 2.8 miles west of High, Tex. (in Gober tongue); on Paris-Bonham Highway; 0.8 mile west of High, Tex. (in Gober tongue), Paris-Bonham Highway; 2.3 miles north of Dallas, Tex., on DallasSherman Highway; 30 yards west of Hillsboro-Corsicana road, 7.75 miles east of Hillsboro, Tex.; 3.4 miles

4 Asano, Kiyosi, Pseudononion, a new genus of Foraminifera found in Muraokamura, Kamakura-gori, Kanagawa Prefecture: Geol. Soc. Japan Jour., vol, 43, no. 512 , pp. $50,51,1956$. toward Farmersville from McKinney Courthouse, Collin County, Tex.; ditch south of highway leading west from McKinney, 3.1 miles west of McKinney, Tex.

Brownstown marl: Ditch south of Greenville-Paris Highway, 3.9 miles south of Paris, Lamar County, Tex.; ditch east of Commerce-Paris Highway, 2.9 miles south of Paris, Lamar County, Tex.; Paris-Clarksville Highway 1.85 miles southeast of Bagwell, Tex.

\section{Nonionella robusta Plummer}

Plate 7, figure 3

Nonionella robusta Plummer, Texas Univ. Bull. 3101, p. 175, pl. 14, fig. 12, 1931.

Nonionina scapha Carsey [not Fichtel and Moll], Texas Univ. Bull. 2612, p. 49, pl. 1, fig. 2, 1926.

Test very small, moderately compressed, about equally biconvex but unsymmetrically developed; periphery narrowly rounded and bluntly angular in maturity, only slightly lobate in later portion of some tests but an even curve on most tests; chambers about eight in the final convolution, rapidly lengthening, gently inflated on most specimens, distinctly but not coarsely punctate; sutures slightly depressed or flush with the contour of the test, somewhat curved; umbilicus on dorsal side small, narrow, depressed, shallow, showing minute chambers of inner whorl; on ventral side umbilical depression filled, with the successive short extensions of the chambers filling the depression irregularly; aperture a low slit on the periphery at base of final chamber.

Length $0.20-0.35 \mathrm{~mm}$; breadth $0.12-0.25 \mathrm{~mm}$; thickness $0.10-0.16 \mathrm{~mm}$.

This seems to be an excellent index fossil for the Navarro group. Some of the specimens of Nonionella cretacea from the Taylor resemble it in some respects, but the number of chambers in $N$. robusta is smaller, and in peripheral view the test is much broader in $N$. robusta than in $N$. cretacea. The whole test is also shorter and thicker.

Navarro group: Bluff on Colorado River at Webberville (Kemp clay), Travis County, Tex.; bank of Colorado River below old ferry at Webberville (Kemp clay), Travis County, Tex.; Tom Thrasher's well, threefourths of a mile from Old Garfield (Kemp clay), Travis County, Tex.; one-fourth of a mile west of Kimbro (Corsicana marl), 2 miles south of Manda, Travis County, Tex.; 2, 18, 23, 30, and 40 feet above base of bluff on Onion Creek (Corsicana marl), $2 \frac{1}{2}$ miles west of Old Garfield, Travis County, Tex.; Black Bluff, Brazos River (Kemp clay), 2 miles above falls, Falls County, Tex.; about 2 miles southwest of Quinlan, Hunt County (Kemp clay?), Tex.; Bankhead Highway (Neylandville marl), 4.3 miles (air line) northeast of public square at Greenville, Hunt County, Tex.; Corsicana clay pit (Corsicana marl), Navarro County, Tex.; 2.1 miles southeast of Drane, Navarro County, Tex. (Neylandville marl); San Marcos River, left bank half a mile below Martindale (Corsicana marl), Caldwell County, Tex.; Jones Crossing on Onion Creek (Corsicana marl), southeast of Austin, Tex. 


\section{Nonionella cretacea Cushman}

Plate 7, figure 5

Nonionella cretacea Cushman, Tennessee Geol. Survey Bull. 41, p. 42, pl. 7, figs. 2a-c, 1931; Geol. Soc. America Bull., vol. 47, p. $418,1936$.

Test much compressed, periphery rounded, dorsal side showing the earliest coils, ventral side involute; chambers numerous, about 10 in the adult whorl, rather rapidly increasing in length in the adult; sutures distinct, slightly depressed, very slightly curved; wall smooth; aperture at the periphery and extending over onto the ventral side, at the base of the final chamber. Length $0.25 \mathrm{~mm}$; breadth $0.18 \mathrm{~mm}$.

This is a small species but rather widely distributed in the Taylor and its equivalents of northern Mexico and the Gulf Coastal Plain region of the United States.

Taylor marl: Medio Creek Valley, a quarter of a mile north of Castroville road (upper part of Taylor), Bexar County, Tex.; Potranca Creek, 0.75 mile south of Castroville road (upper part of Taylor), Bexar County, Tex.; 1.4 miles north of Emhouse (upper part of Taylor), Navarro County, Tex., on road toward Ennis.

Annona chalk: 0.75 mile north toward White Rock, 6.95 miles east of Clarksville, Red River County, Tex.

Selma chalk: Half a mile west of Guys, MeNairy County, Tenn.; New Corinth Highway $13 \frac{1}{2}$ miles south of Selmer, McNairy County, Tenn.

Velasco shale: Hacienda El Limón, Vera Cruz, Mexico.

\section{Nonionella warburgi Brotzen}

Plate 7, figure 4

Nonionella warburgi Brotzen, Sveriges geol. undersökning, ser. C, no. 396, p. 117, pl. 8, figs. 11a-c, 1936.

Test slightly longer than broad, periphery rounded, sides nearly parallel, dorsal side completely evolute, ventrally involute; chambers seven or eight in the lastformed whorl, increasing rather regularly in size as added, the last-formed chamber occupying but a small portion of the ventral side; sutures distinct, strongly curved in the later part, less so in the early part, slightly depressed; wall smooth; aperture a small slit at the base of the last-formed chamber. Length of holotype, $0.27 \mathrm{~mm}$; breadth $0.19 \mathrm{~mm}$; thickness 0.09 $\mathrm{mm}$.

The types came from the Cretaceous lower Senonian of Eriksdal, Sweden.

\section{Nonionella extensa Brotzen}

Plate 7, figure 7

Nonionella extensa Brotzen, Sveriges geol. undersökning, ser. C, no. 396, p. 116, pl. 10, figs. 8a-c, 1936.

Test about one and a half times as long as broad, periphery rounded, ventral side with the umbilical area covered, strongly convex, in apertural view with the sides nearly parallel; chambers about nine in the adult coil, rapidly increasing in length as added, the final one greatly enlarged and tumid, extending nearly to the periphery at the base on both sides but broader and more tumid on the ventral side and making up more than half the area of the test ventrally; sutures slightly curved, little if at all depressed; wall smooth; aperture very small. Length of holotype, $0.34 \mathrm{~mm}$; breadth $0.20 \mathrm{~mm}$; thickness $0.14 \mathrm{~mm}$.

The types came from the Cretaceous lower Senonian of Eriksdal, Sweden.

\section{Nonionella reussana Cushman, n. sp.}

Plate 7, figure 6

Test somewhat compressed, periphery rounded, dorsal side showing a small amount of the previous coil, ventral side completely involute; chambers distinct, slightly inflated, few, about seven in the adult whorl, increasing rather rapidly in size in the final whorl; sutures distinct, slightly depressed, slightly curved dorsally, strongly so ventrally, the last ones sigmoid; wall smooth; aperture a low opening at the base of the last-formed chamber, extending slightly into the ventral side. Length $0.30 \mathrm{~mm}$; breadth $0.25 \mathrm{~mm}$; thickness $0.15 \mathrm{~mm}$.

Holotype (Cushman Coll., no. 23619) from Upper Cretaceous, Mersch bei Hamm, Germany.

This is a broader species than the other Cretaceous ones from America.

\section{Nonionella alabamensis Cushman and Ponton}

Plate 7, figure 12

Nonionella alabamensis Cushman and Ponton, Cushman Lab. Foram. Research Contr., vol. 8, p. 65, pl. 8, figs. 15a-c, 1932.

Test slightly longer than broad, periphery rounded, the last-formed chamber covering the umbilical area on one side, the opposite side showing the earlier coils; chambers distinct, slightly inflated, 8 to 10 in the lastformed coil, the last-formed chamber covering the umbilicus and often showing a stellate form, increasing gradually in size and length as added; sutures distinct, slightly depressed, often somewhat limbate, particularly on the side with the open umbilicus; wall smooth, finely perforate; aperture extending from the periphery under the stellate projection of the last-formed chamber. Length $0.50 \mathrm{~mm}$; breadth $0.35 \mathrm{~mm}$; thickness $0.20 \mathrm{~mm}$.

The types of this species came from the Wilcox Eocene (Tuscahoma sand), from a railroad cut 1 mile north of Ozark, Ala.

This species somewhat resembles forms found in the late Tertiary of the Pacific coast, but the sutures are usually distinctly limbate in the young stages at least, and the form in the peripheral view is broader. 


\section{Nonionella wilcoxensis Cushman and Ponton}

Plate 7, figure 13

Nonionella wilcoxensis Cushman and Ponton, Cushman Lab. Foram. Research Contr., vol. 8, p. 65, pl. 8, figs. 12a, b, 1932.

Test very much compressed, periphery rounded, somewhat unequal on the two sides; chambers distinct, 10 to 12 in the last-formed coil, increasing regularly in size and length as added, slightly inflated; sutures distinct, strongly curved, very slightly if at all depressed except at the inner end; wall smooth, very finely perforate; aperture an elongate slit at the base of the apertural face in the median line. Length $0.45 \mathrm{~mm}$; breadth $0.30 \mathrm{~mm}$; thickness $0.15 \mathrm{~mm}$.

The types of this species came from the Wilcox Eocene (Tuscahoma sand), from a railroad cut 1 mile north of Ozark, Ala.

This species is distinctly umbilicate on one side, showing the early coils and the spiral suture; on the other side the early coils are covered. There is a tendency for the wall to be slightly papillate at the base of the chambers.

\section{Nonionella insecta (Schwager) Cushman and Ponton}

Plate 8, figure 1

Anomalina insecta Schwager, Palaeontographica, vol. 30, Pal. Theil, p. 128, pl. 28 (5), figs. 1a-d, 2a-e, 1883.

Nonionella insecta Cushman and Ponton, Cushman Lab. Foram. Research Contr., vol. 8, p. 65, pl. 8, figs. 13, 14, 1932.

Test much compressed, only slightly higher than broad, sides flattened, periphery rounded to subacute, dorsal side showing the earlier whorls, ventral side almost completely involute; chambers distinct, slightly if at all inflated, increasing rapidly in length in the final whorl; sutures distinct, slightly depressed, nearly straight, very oblique in the adult; wall smooth; aperture low, at the base of the last-formed chamber extending over slightly on the ventral side. Length $0.25 \mathrm{~mm}$; breadth $0.20 \mathrm{~mm}$; thickness $0.08 \mathrm{~mm}$.

This species was originally described from the middle Eocene of northern Africa. The same form evidently occurs in the Wilcox Eocene (Tuscahoma sand), railroad cut 1 mile north of Ozark, Ala. The specimen here figured is from the latter locality.

\section{Nonionella gardnerae Cushman}

Plate 7, figure 8

Nonionella gardnerae Cushman, Cushman Lab. Foram. Research Contr., vol. 12, p. 88, pl. 15, figs. 9a-c, 1936.

Test slightly trochoid, moderately compressed, dorsal side slightly evolute, showing a slight trace of the earlier whorl, ventral side completely involute; chambers distinct, slightly inflated, about 10 in the final whorl, increasing gradually in size as added, slightly overlapping, last-formed one with a ventral lobe extending over the umbilicus; sutures distinct, slightly de- pressed, gently curved; wall smooth, finely perforate; aperture a low arched opening at the base of the periphery of the last-formed chamber, extending slightly on the ventral side. Length $0.35 \mathrm{~mm}$; breadth $0.25 \mathrm{~mm}$; thickness $0.17 \mathrm{~mm}$.

The types of this species came from the Eocene Claiborne (Cook Mountain), bluff on San Antonio River 4 miles southwest of Floresville, Tex.

\section{Nonionella cockfieldensis Cushman and Ellisor}

Plate 7, figures $9-11$

Nonionella cockfieldensis Cushman and Ellisor, Cushman Lab. Foram. Research Contr., vol. 9, p. 95, pl. 10, fig. 11, 1933.

Test nearly bilaterally symmetrical, almost completely involute, later chambers on the ventral side extending below the umbilicus in a broad curve, periphery rounded; chambers very distinct, not inflated, about 10 in the adult coil; sutures distinct, not depressed, gently curved; wall smooth; aperture extending over onto the ventral side beneath the extension of the chamber. Length $0.40 \mathrm{~mm}$; breadth $0.35 \mathrm{~mm}$; thickness $0.18 \mathrm{~mm}$.

The types of this species came from the Claiborne Eocene, Yegua formation, a quarter of a mile below Robertson's Ferry on the Sabine River, Sabine County, Tex. The species also occurs in our collections from the Ocala limestone, second bed above the Gosport sand, Claiborne, Monroe County, Ala., and from the Cook Mountain formation, bluff on San Antonio River 4 miles south-southeast of Floresville, Wilson County, Tex.

\section{Nonionella jacksonensis Cushman}

Plate 8, figure 2

Nonionella jacksonensis Cushman, Cushman Lab. Foram. Research Contr., vol. 9, p. 10, pl. 1, figs. 23a-c, 1933; U. S. Geol. Survey Prof. Paper 181, p. 31, pl. 12, figs. 3, 4, 1935.

Test longer" than broad, periphery rounded, ventral side involute and the chambers extending over the umbilical region, dorsal side with the chambers ending at the umbilical region; chambers distinct, about 8 in the final whorl, becoming increasingly elongate in the adult, the inner end of the final chamber extending across the umbilical area nearly to the periphery on the ventral side, inflated; sutures distinct, slightly if at all depressed; wall smooth, finely perforate; aperture peripheral at the base of the apertural face, low. Length $0.35 \mathrm{~mm}$; breadth $0.20 \mathrm{~mm}$; thickness $0.10 \mathrm{~mm}$.

This species has resemblances to $N$. turgida (Williamson), but the chambers are broader and usually fewer.

The species is known from the Cooper marl of Charleston, S. C.; and from the Ocala limestone at Claiborne, Ala.; $6 \frac{1}{2}$ miles north of Brooklyn, Ala.; and 31/2 miles northeast of Brooklyn, Ala. 


\section{Nonionella danvillensis Howe and Wallace}

Plate 8, figure 3

Nonionella danvillensis Howe and Wallace. Louisiana Dept. Cons. Geol. Bull. 2, p. 52, pl. 9, figs. 5a-c, 1932.

Test trochoid, asymmetrical, low spired, periphery broadly rounded; chambers numerous, about eight being visible on the ventral side, all visible on the dorsal side, the last two chambers forming a shield over the umbilical area on the ventral side; sutures distinct, very slightly depressed if at all, slightly curved; wall smooth, calcareous, fineiy perforate; aperture at the base of the last-formed chamber extending from the periphery ventrally. Greatest diameter $0.3 \mathrm{~mm}$; thickness $0.13 \mathrm{~mm}$.

This species is from the Jackson Eocene at Danville Landing, Ouachita River, Catahoula Parish, La. The figured specimen is a paratype kindly furnished by the authors.

\section{Nonionella hantkeni (Cushman and Applin) Ellisor}

Plate 8 , figure 4

Nonionina hantkeni Cushman and Applin, Am. Assoc. Petroleum Geologists Bull., vol. 10, p. 182, pl. 10, figs. 10, 11, 1926. Nonionella hantkeni Ellisor, Am. Assoc. Petroleum Geologists Bull., vol. 17, no. 11, pl. 2, fig. 9, 1933.

Cushman, U. S. Geol. Survey Prof. Paper 181, p. 31, pl. 12, figs. 1, 2, 1935.

Pullenia elongata Hantken, Magyar kir. földt. int. Evkönyve, 1875 , p. 50, pl. 10, fig. 10, 1876; K. ungar. geol. Anstalt Mitt. Jahrb., vol. 4, p. 59, pl. 10, fig. 10, 1881.

Test somewhat longer than broad, consisting of numerous chambers, as many as 12 in the last-formed coil, periphery broadly rounded, the umbilical region slightly exposed, showing the inner ends of the earlier chambers; sutures distinct, very slightly and evenly curved; wall smooth; aperture arched in the base of the apertural face of the last-formed chamber. Maximum length $0.60 \mathrm{~mm}$.

The types of this species are from the Jackson Eocene of the Ohio and Red River well no. 2, Tyler County, Tex., at a depth of 2,330 feet.

East of Texas, in the Eocene of the Gulf Coastal Plain, the species is apparently replaced by var. spissa Cushman.

Besides the types our collections contain specimens from the Jackson Eocene of Stovall Creek, east of Diboll, Angelina County, Tex.; Tar Kiln Creek half a mile above Neches River, Tex., and numerous well samples from the Eocene. The same species occurs in the upper Eocene along the Río Tuxpan, Vera Cruz, Mexico.

\section{Nonionella hantkeni (Cushman and Applin) var. spissa Cushman}

\section{Plate 8, figure 5}

Nonionella hantkeni (Cushman and Applin) var. spissa Cushman, Cushman Lab. Foram. Research Contr., vol. 7, pt. 3, p. 58, pl. 7, figs. 13a-c, 1931 .

Ellisor, Am. Assoc. Petroleum Geologists Bull., vol. 17, no. 11, pl. 2, figs. 10-12, 1933.
Cushman, U. S. Geol. Survey Prof. Paper 181, p. 31, pl. 12, figs. $6 a-c, 1935$.

Variety differing from the typical form in the much thicker test, usually smaller number of chambers, and less limbate sutures.

The types of the variety came from the Jackson Eocene Cooper marl at the end of a fill on the west side of the Santee Canal on U. S. Highway 17 three-quarters of a mile west of old Biggin Church, Berkeley County, S. C. The variety also occurs in the Cooper marl at other localities in South Carolina, in the Ocala limestone of Alabama, and in the Jackson formation of Mississippi.

\section{Nonionella hantkeni (Cushman and Applin) var. fayettei (Cushman and Ellisor) Ellisor}

Plate 8, figure 6

Nonion hantkeni (Cushman and Applin) var. fayettei Cushman and Ellisor, Cushman Lab. Foram. Research Contr., vol. 8, p. 41, pl. 6, figs. 3a, b, 1932.

Nonionella hantkeni (Cushman and Applin) var. fayettei Ellisor, Am. Assoc. Petroleum Geologists Bull., vol. 17, pl. 7, figs. 9a, b, 1933.

Test elongate, much compressed, slightly umbilicate, periphery rounded; chambers distinct, numerous, 10 to 12 in the last-formed whorl in the adult, increasing somewhat in length as added but changing very little in height; sutures distinct, slightly curved, those of the early portion limbate and often slightly raised, later ones becoming flush with the surface and the limbate character disappearing; wall smooth except for the slightly raised limbate sutures in the earlier portion, very finely perforate; aperture a narrow slit at the base of the apertural face of the last-formed chamber, between it and the preceding coil. Length $0.50 \mathrm{~mm}$ : breadth $0.35 \mathrm{~mm}$; thickness $0.15 \mathrm{~mm}$.

The types of this species came from the Jackson Eocene on the east bank of Toro Bayou in the SE $1 / 4 \mathrm{NW}^{1 / 4}$ sec. 6 , T. 3 N., R. 11 W., Vernon Parish, La.

This variety seems to be a definite marker for the Fayette sandstone of the upper Eocene. The limbate suture lines and the very considerable compression, with the sides almost parallel, will distinguish the variety. The last-formed chamber seems to be very delicate and is usually broken away, leaving a sharp line about the peripheral face, as shown in the figure.

\section{Nonionella frankei Cushman}

Plate 8, figure 7

Nonionella frankei Cushman, Cushman Lab. Foram. Research Contr., vol. 12, p. 88, pl. 15, figs. 10a-c, 1936.

Test slightly trochoid, slightly compressed, dorsal side somewhat evolute, showing the earlier whorls, ventral side involute, deeply umbilicate; chambers distinct, slightly inflated, about 10 in the final whorl, increasing rather rapidly in size as added, final chamber extending slightly more onto the ventral side, without 
a definite lobe; sutures distinct, slightly depressed, nearly straight; wall smooth; aperture a low arched opening at the base of the apertural face. Length $0.35 \mathrm{~mm}$; breadth $0.25 \mathrm{~mm}$; thickness $0.22 \mathrm{~mm}$.

The types came from the middle Oligocene Rupelton of Dusseldorf, Ratigen, Germany.

\section{Nonionella tatumi Howe}

Plate 8 , figure 8

Nonionella tatumi Howe, Jour. Paleontology, vol. 4, p. 330, pl. 27, figs. $6 a-c, 1930$.

Ellisor, Am. Assoc. Petroleum Geologists Bull., vol. 17, pl. 2, fig. 11, 1933.

Test subtrochoid, small, periphery broadly rounded, usually nine chambers in the last-formed coil, distinct, dorsal side not completely involute. Sutures nearly straight. Ventral side involute, with the last-formed chamber having an extension the end of which is generally divided into 3 or more small lobes, which completely cover the umbilical area. Aperture low, arched, at the base of the last-formed chamber. Length 0.30 $\mathrm{mm}$; breadth $0.25 \mathrm{~mm}$; thickness $0.10 \mathrm{~mm}$.

The types of this species came from the Oligocene Mint Spring marl member of the Marianna limestone, 50 yards below the waterfalls in Mint Spring Bayou, Vicksburg, Miss. It also is recorded from the Byram marl at Byram, Miss., and from the Red Bluff clay at Hiwannee, Miss. The figured specimen is a paratype, kindly sent to me by Dr. Howe.

\section{Nonionella miocenica Cushman}

Plate 8, figure 9

Nonionella miocenica Cushman, Cushman Lab. Foram. Research Contr., vol. 2, pt. 3, p. 64, 1926; Scripps Inst. Oceanography Bull., Tech. ser., vol. 1, p. 149, 1927.

Cushman, Stewart, and Stewart, San Diego Soc. Nat. History Trans., vol. 6, p. 61, pl. 8, figs. 6a-c, 1930.

Cushman and Parker, Cushman Lab. Foram. Research Contr., vol. 7, p. 8, 1931.

Cushman, Cushman Lab. Foram. Research Special Pub. 5, pl. 23, figs. 3a-c, 1933.

Barbat and Johnson, Jour. Paleontology, vol. 8, p. 11, pl. 1, figs. 1-4, 1934.

Nonionina auris Cushman [not D'Orbigny], Cushman Lab. Foram. Research Contr., vol. 1, pt. 4, p. 91, pl. 13, figs. $4 a-c, 1926$.

Test subtrochoid, small, periphery broadly rounded, 8 to 10 chambers in the last-formed coil, distinct, dorsal side not completely involute, the sutures obliquely curved, the last chambers with the umbilical end forming a distinct rounded lobe; wall smooth; aperture low, elongate. Length $0.45 \mathrm{~mm}$; breadth $0.35 \mathrm{~mm}$; thickness $0.25 \mathrm{~mm}$.

This species occurs in the Miocene of California, in the Monterey shale of San Luis Obispo and Humboldt Counties, in the Temblor of the east side of San Joaquin Valley, and in the Reef Ridge shale of the west side of San Joaquin Valley. It also occurs off the western coast of Mexico as a living form.

1819-39-3

\section{Nonionella novo-zealandica Cushman}

Plate 8, figure 10

Nonionella novo-zealandica Cushman, Cushman Lab. Foram. Research Contr., vol. 12, p. 88, pl. 13, figs. 16a-c, 1936.

Test trochoid, biconvex, dorsal side somewhat flattened, the spire slightly sunken, slightly evolute, ventral side involute, the central area with irregular raised masses, rounded and elongate, periphery rounded; chambers distinct, 12 to 14 in the adult whorl, increasing rapidly in size as added, slightly inflated; sutures distinct, very slightly depressed, earlier ones more strongly curved than the later ones; wall smooth except for the ornamentation of the ventral umbilical region; aperture a low opening at the base of the apertural face. Length $0.50 \mathrm{~mm}$; breadth $0.40 \mathrm{~mm}$; thickness $0.20 \mathrm{~mm}$.

The types came from the Miocene Shell bed in Target Gully, Oamaru, New Zealand.

\section{Nonionella pseudo-auris Cole \\ Plate 8, figures 11, 12}

Nonionella pseudo-auris Cole, Florida Geol. Survey Bull. 6, p. 32 , pl. 5, figs. 4, 5, 1931.

Test small, subtrochoid, the final volution composed of 7 or 8 chambers; periphery rounded; sutures rather indistinct between the initial chambers of the final whorl, becoming more pronounced between the final chambers in this whorl, very slightly recurved, the last chamber produced into a distinct lobe on the ventral side, which completely fills the umbilicus; wall finely perforate; aperture low, elongate. Length, $0.32 \mathrm{~mm}$; width, $0.22 \mathrm{~mm}$

This species was described from the Pliocene Caloosahatchee marl of the City marl pit, Orange County, Fla.

It is close to $N$. miocenica Cushman but has fewer chambers and less distinct sutures.

\section{Nonionella clavata Cushman}

Plate 8, figure 15

Nonionella clavata Cushman, Cushman Lab. Foram. Research Contr., vol. 7, pt. 2, p. 30, pl. 4, figs. 9a-c, 1931; Bernice P. Bishop Mus. Bull. 119, p. 121, pl. 14, figs. 11a-c, 1934.

Test elongate, broadest near the outer end, making the shape in peripheral view clavate, periphery very broadly rounded; chambers 8 to 10 in the last-formed coil, distinct, the later ones very much elongated; sutures distinct, limbate, slightly curved; wall smooth, finely perforate; aperture a very narrow slit at the base of the apertural face. Length $0.55 \mathrm{~mm}$; breadth 0.30 $\mathrm{mm}$; thickness $0.18 \mathrm{~mm}$.

The types of this species came from the Pliocene of Fiji. It is a very peculiar shaped species, the last chambers being very greatly extended and swollen at the outer end. The test is almost bilaterally symmetrical but not entirely so. 


\section{Nonionella limbato-striata Cushman}

Plate 8, figures 13, 14

Nonionella limbato-striata Cushman, Cushman Lab. Foram. Research Contr., vol. 7, pt. 2, p. 30, pl. 4, figs. 8a-c, 1931; Bernice P. Bishop Mus. Bull. 119, p. 121, pl. 14, figs. 10a-c, 1934.

Test much longer than broad, trochoid, completely involute on the ventral side, whole test compressed, very narrow in peripheral view, the periphery rounded; chambers distinct, 8 to 10 in the last-formed coil, gradually increasing in length, especially in the last few chambers, not inflated; sutures distinct, curved, limbate, very broad on the ventral side; wall smooth, finely perforate; aperture a narrow slit at the base of the apertural face. Length $0.30 \mathrm{~mm}$; breadth 0.15 $\mathrm{mm}$; thickness $0.06 \mathrm{~mm}$.

The types of this species came from the Pliocene of Fiji. It is a small but very distinct species, and the broad sutures, being of peculiar type, will at once distinguish it from other species of the genus. On plate 8 are figures of a Recent form from Vavau Anchorage, Tonga Islands, which seem to be this species. It was previously referred to as "Nonionella auris (D'Orbigny) var."

\section{Nonionella tredeca (Asano) Cushman}

Plate 8, figure 16

Pseudononion tredecum Asano, Geol. Soc. Japan Jour., vol. 43, no. 515 , p. 622 , pl. 33 , figs. $7 \mathrm{a}-\mathrm{c}, 1936$.

Test depressed, bilaterally asymmetrical, ventral side completely involute, dorsal side somewhat evolute, periphery subacute, umbilicus of ventral side distinct, filled with granular shell substance; chambers numerous, usually 13 or 14 in lastformed coil in adult; sutures distinct, slightly depressed; wall smooth, finely perforate; aperture small, at base of last chamber. Length about 0.4 , breadth 0.3 , and thickness $0.1 \mathrm{~mm}$.

The types came from the Neogene of Kaigarasawa, Kuromatunaimura, Suttu-gun, Hokkaidô, Japan.

\section{Nonionella japonica (Asano) Cushman}

Plate 9, figure 1

Pseudononion japonicum Asano, Geol. Soc. Japan Jour., vol. 43, no. 512, p. 347, text figs. A-C, 1936.

Test asymmetrical, depressed, dorsal side slightly convex with all coils visible, ventral side with only the last-formed coil visible, periphery subacute; chambers distinct, 10 to 12 in adult, having no elongate lobe extending over the umbilicus on the ventral side; sutures distinct, slightly depressed, gently curved; wall finely perforate; aperture a narrow slit at the base of the apertural face. Length $0.40 \mathrm{~mm}$; breadth $0.25 \mathrm{~mm}$; thickness $0.1 \mathrm{~mm}$.

The types of this species came from the late Tertiary of Muraoka-mura, Kamakura-gôri, Kanagawa Prefecture, Japan.

\footnotetext{
5 Cushman, J. A., The foraminifera of the tropical Pacific collections of the Albatross 1899-1900, U. S. Nat. Mus. Bull. 161, pt. 2, Lagenidae to Alveolinellidae, pl. 10, figs. $11 \mathrm{a}-\mathrm{c}, 1933$.
}

Nonionella janiformis (Jones) Cushman

Plate 8, figure 17

Nonionina boueana D'Orbigny var. janiformis Jones, Foraminifera of the Crag, pt. 4, p. 343, text figs. 28a-c, 1897.

The varietal form under notice has a nearly circular outline and subacute peripheral edge; it is stoutly made, and the chambers, which are numerous, narrow, falciform, and slightly inflated, increase rather rapidly in size toward the end. Some specimens are rather more oval than others. One umbilicus is exposed, and on this side the sutures are visible from the periphery to the umbilicus, but the other umbilicus is covered with granular shell substance. Thus the variety under notice has at once the two characters that divide the Nonioninae into two series. Hence it may be called janiformis.

Numerous specimens in good condition were found by $\mathrm{Mr}$. Millett in the Coralline Crag at Gomer, or Gomer Field (now ploughed over), between the ferry on the River Butley and Gedgrave, Suffolk.

The specimen here figured is evidently the same as Millett's species. It came from the Pliocene Coralline Crag of Sutton, England.

\section{Nonionella turgida (Williamson) Cushman}

Plate 9, figures 2, 3

Rotalina turgida Williamson, On the Recent Foraminifera of Great Britain, p. 50, pl. 4, figs. 95-97, Royal Soc. London, 1858.

Nonionina asterizans var. turgida Parker and Jones, Introduction to study of Foraminifera, appendix, p. 311, 1862.

Nonionina turgida H. B. Brady, Linnean Soc. London Trans., vol. 24, p. 474, 1864; Challenger Rept., Zoology, vol. 9, p. 731, pl. 109, figs. 17-19, 1884.

Balkwill and Wright, Royal Irish Acad. Trans., vol. 28, Sci., p. 352, 1885.

Terquem and Terquem, Soc. zool. France Bull., vol. 11, p. 331 , pl. 11, figs. 7, 8, 1886 .

Siddall, Lit. Philos. Soc. Liverpool Proc., 1886, p. 71 (list).

Wright, Annals and Mag. Nat. History, ser. 6, vol. 4, p. 449, 1889.

Halkyard, Manchester Micr. Soc. Trans., p. 71, 1889.

Robertson, Nat. History Soc. Glasgow Trans., vol. 3, pt. 3, p. 242, 1892.

Chaster, Southport Soc. Nat. Sci. 1st Rept., 1890-91, p. 66, 1892.

Wright, Royal Irish Acad. Proc., ser. 3, vol. 1, p. 493, 1891.

?Egger, K. bayer. Akad. Wiss. Abh., Cl. 2, vol. 18, p. 425, pl. 19, figs. 45, 46, 1893.

Goës, K. svenska vetensk. akad. Handl., vol. 25, no. 9, p. 105, pl. 17, fig. 832, 1894.

Wright, Irish Naturalist, vol. 9, p. 55, 1900.

Kiaer, Rept. Norwegian Fish. and Mar. Invest., vol. 1, no. 7 , p. 50, 1900; in Duc d'Orléans, Croisière océanographique accomplie à bord de la Belgica dans la Mer du Grönland, 1905, p. 526, 1907.

Millett, Recent Foraminifera of Galway, p. 7, 1908.

Heron-Allen and Earland, Royal Irish Acad. Proc., vol. 31, pt. 64, p. 145, 1913; Linnean Soc. London Trans., ser. 2, vol. 11, p. 281, 1916.

Nonionella turgida Cushman, U. S. Nat. Mus. Bull. 104, pt. 7, p. 15, pl. 6, figs. 1-4, 1930 .

Howe and Wallace, Louisiana Dept. Cons. Geol. Bull. 2, p. 53, pl. 9, figs. $2 x-c, 1932$.

Earland, Discovery Repts., vol. 7. p. 131, 1933; vol. 10, p. 190, 1934. 
T'est longer than broad, much compressed, irregularly heart-shaped, periphery rounded, the dorsal side slightly evolute, ventral side involute; chambers distinct, increasing rapidly in size and length as added, slightly if at all inflated, except on the ventral side, where the last-formed one has an enlarged portion over the umbilical area; sutures distinct, not depressed, inner portion nearly straight and radial, toward the periphery more strongly curved; wall smooth; aperture below the bulbous portion of the last chamber at the ventral side. Length $0.25-0.30 \mathrm{~mm}$; breadth $0.15-0.18 \mathrm{~mm}$; thickness $0.10-0.12 \mathrm{~mm}$.

This is a common species about the British Isles and adjacent areas. There are many records without figures from other regions, which need to be checked from the original sources. It occurs in fairly deep water off the coast of New England. Some of the European records follow: Skye, Arran, Shetland, abundant; Whitehaven, rare (Williamson); off the Dublin coast (Balkwill and Wright); south of Norway (Terquem and Terquem); Liverpool Bay, rare (Siddall); southwest of Ireland, 1,000 fathoms, frequent (Wright); Isle of Jersey (Halkyard); Portree Bay, Scotland, frequent (Robertson); off Southport, England, rather rare (Chaster); West Africa (Egger); Scandinavian coast (Goës); Dogs Bay, very rare (Wright); south coast of Norway from Brevik Fiord to the Bukn Fiord, 90 to 350 meters, and Svolvaer, Lofoten, 200 meters; Vesteraalseggen, 1,187 meters (Kiaer); off Galway (Millett); Clare Island region of Ireland at 16 stations; 20 stations west of Scotland (Heron-Allen and Earland). There are records of it in the Pleistocene beds of Norway, Scotland, and Ireland.

\section{Nonionella auris (D'Orbigny) Cushman and Kellett}

\section{Plate 9, figure 4}

Valvulina auris D'Orbigny, Voyage dans l'Amérique méridionale, vol. 5 , pt. 5 , Foraminifères, p. 47, pl. 2, figs. 15-17, 1839 .

Nonionina auris Cushman, Cushman Lab. Foram. Research Contr., vol. 1, pt. 2, p. 44, pl. 7, figs. 3a-c, 1925.

Hada, Sapporo Nat. History Soc. Trans., vol. 11, pt. 1, p. $14,1929$.

Nonionella auris Cushman and Kellett, U. S. Nat. Mus. Proc., vol. 75, art. 25, p. 5, pl. 1, figs. 9a-c; pl. 2, figs. 2, 3, 1929.

Cushman, Florida Geol. Survey Bull. 4, p. 38, pl. 7, figs. 1a-c, 1930.

Cushman and Ponton, Florida Geol. Survey Bull. 9, p. 69, 1932.

Heron-Allen and Earland, Discovery Repts., vol. 4, p. 438, pl. 16, figs. 17-19, 1932.

Cushman and Cahill, U. S. Geol. Survey Prof. Paper 175-A, p. 21, pl. 7, figs. 6a, b, 1933.

Cushman, Cushman Lab. Foram. Research Special Pub. 4, pl. 19, figs. 2a-c, 1933; U. S. Nat. Mus. Bull. 161, pt. 2, p. 45, pl. 10, fig. 10 [not 11]; pl. 11, figs. 1a-c, 1933.

Palmer and Bermúdez, Soc. cubana historia nat. Mem., vol. 9, p. 245, 1935.

Cushman, Geol. Soc. America Bull., vol. 47, pl. 5, figs. 1a-c, 1936 .
Test asymmetrical, slightly trochoid, the spire not raised, periphery in the adult broadly rounded; chambers 9 to 11 in the adult, low and broad, very distinct, slightly inflated, in the adult with the last-formed chamber having an enlarged portion extending over the umbilicus on the ventral side; sutures distinct, depressed, gently curved; wall smooth, polished, very finely perforate; aperture at the last-formed chamber, extending from the periphery ventrally, low and broad. Length $0.35 \mathrm{~mm}$; breadth $0.25 \mathrm{~mm}$; thickness $0.10 \mathrm{~mm}$.

D'Orbigny's types came from the west coast of South America, where the species is recorded as often abundant from Chile to Ecuador. I have had material from Payta, Pimentel, and Eten, Peru; from Corral and Lota, Chile; from the tropical Pacific; and from off British Columbia. It is also recorded from off Hokkaido, Japan (Hada); and off the Falkland Islands (HeronAllen and Earland). As a fossil it is known from the Miocene Choctawhatchee, Shoal River, Oak Grove, and Chipola of Florida, from the Miocene St. Marys and Calvert formations of Maryland, from the late Tertiary of the Matanzas Bay region, Cuba, and from the submarine late Tertiary clays of Georges Bank.

\section{Nonionella chiliensis Cushman and Kellett}

Plate 9, figure 6

Nonionella chiliensis Cushman and Kellett, U. S. Nat. Mus. Proc., vol. 75, art. 25, p. 6, pl. 2, figs. 4a-c, 1929.

Heron-Allen and Earland, Discovery Repts., vol. 4, p. 438, pl. 16, figs. 11-13, 1932.

Test asymmetrical, trochoid, the spire very much flattened, consisting of about $2 \frac{1}{2}$ whorls, periphery subacute, umbilicus depressed; chambers numerous, 10 to 12 in the last-iormed whorl, low and broad, not inflated; sutures distinct, not depressed, strongly limbate, on the dorsal side oblique, ventrally strongly curved; wall smooth, polished, very finely perforate; aperture low, elongate, at the margin of the chamber extending from the periphery ventrally. Maximum height $0.40 \mathrm{~mm}$; breadth 0.35 $\mathrm{mm}$; thickness $0.18 \mathrm{~mm}$.

The types of this species are from off Corral, Chile, and it also occurred in material from Lota, Chile. Heron-Allen and Earland record it from off the Falkland Islands.

This is an extreme form of the genus, more asymmetrical than most species.

\section{Nonionella auricula Heron-Allen and Earland}

\section{Plate 9, figures 7-9}

Nonionella auricula Heron-Allen and Earland, Royal Micr. Soc. Jour., vol. 50, p. 192, pl. 5, figs. 68-70, 1930.

Test longer than broad, strongly compressed, periphery rounded, ventrally umbilicate and involute, dorsally with the earlier coils visible; chambers distinct, about nine in the adult whorl, inflated, increasing rapidly in size and height in the adult whorl; sutures distinct, depressed in later portion, slightly curved; wall thin, hyaline, smooth; aperture at the base of the ventral face 
extending over slightly onto the ventral side. Length $0.18-0.25 \mathrm{~mm}$; breadth $0.14-0.16 \mathrm{~mm}$; thickness 0.12 $\mathrm{mm}$.

The types of this species came from a depth of 30 to $31 \frac{1}{2}$ fathoms off Plymouth, England.

\section{Nonionella iridea Heron-Allen and Earland}

\section{Plate 9, figure 5}

Nonionella iridea Heron-Allen and Earland, Discovery Repts., vol. 4, p. 438, pl. 16, figs. 14-16, 1932.

Earland, idem, vol. 10, p. 190, 1935; vol. 13, p. 58, 1936.

Test minute, hyaline, consisting of about 12 to 14 chambers, arranged inequilaterally in an evolute spiral. Six or seven of the chambers are exposed on one side of the test, the whole of the series more or less visible on the other. The primordial chamber often appears as a central boss. Sutures depressed, and chambers more or less inflated. Peripheral edge broad, slightly Jobulate. Color glassy to white, often iridescent owing to diffraction spectra caused by the thinness of the shell.

Length $0.20 \mathrm{~mm}$; breadth $0.15 \mathrm{~mm}$; thickness 0.11 $\mathrm{mm}$.

This species is recorded by the authors from several stations in the general region of the Falkland Islands and more abundant in the South Georgia areas. Earland records it from the Weddell Sea.

\section{Nonionella miocenica Cushman var. stella Cushman and} Moyer

Plate 9, figure 10

Nonionella miocenica Cushman var. stella Cushman and Moyer, Cushman Lab. Foram. Research Contr., vol. 6, p. 56, pl. 7 , figs. $17 \mathrm{a}-\mathrm{c}, 1930$.

Variety differing from the typical form in the stellate character of the inner end of the last-formed chamber on the ventral side which develops short fingerlike processes over the previous sutures.

The types of this variety came from depths of 35 to 50 fathoms off San Pedro, Calif. This is very close to $N$. pulchella Hada, from Japan, but the California form has fewer and broader chambers, and the test is more rounded.

\section{Nonionella pulchella Hada}

\section{Plate 9, figure 11}

Nonionella pulchella Hada, Tohoku Imp. Univ. Sci. Rept., ser. 4, Biology, vol. 6, p. 120, fig. 79 (in text), 1931.

Test oval, compressed, composed of about two convolutions, peripheral margin rounded; chambers narrow, curved, increasing rapidly in size as added, all chambers in the outer whorl visible, umbilical end of the chamber growing in peculiar manner and covering over the umbilicus in the ventral side; sutures distinct, depressed slightly; wall smooth, somewhat translucent or opaque, finely perforate; aperture forming a narrow, arched slit. Iength $0.45 \mathrm{~mm}$; breadth $0.30 \mathrm{~mm}$; thickness $0.18 \mathrm{~mm}$.

This species was described from Mutsu Bay, Japan, where it is recorded at depths ranging from 4 to 33 fathoms.

\section{Nonionella parri Cushman}

Plate 9, figure 12

Nonionella parri Cushman, Cushman Lab. Foram. Research Contr., vol. 12, p. 89, pl. 13, figs. 17a-c, 1936.

Test slightly longer than broad, strongly compressed, periphery in the earlier portion rounded, becoming subacute in the later portion, dorsal side with the earlier whorls visible, ventrally nearly involute; chambers distinct, numerous, 16 to 18 in the adult whorl, increasing rather gradually in size and height, not inflated; sutures distinct, somewhat limbate, little if at all depressed, earlier ones slightly curved, later ones sigmoid; wall smooth except for the umbilicate region on the ventral side, which has a few short costae and the inner ends of the chambers with a small, blunt spine; aperture low, at the ventral side of the periphery. Length $0.75 \mathrm{~mm}$; breadth $0.50-0.60 \mathrm{~mm}$; thickness $0.30 \mathrm{~mm}$.

The types of this species came from shore sand, Caroline Bay, Timaru, New Zealand.

The species is named in honor of Mr. W. J. Parr, who has furnished us with much interesting material.

\section{Nonionella translucens Cushman \\ Plate 9, figure 13}

Nonionella translucens Cushman, U. S. Nat. Mus. Bull. 161, pt. 2, p. 45, pl. 11, figs. 2a-c, 1933.

Test small, elongate, dorsal side flattened or slightly convex, with all the coils visible, ventral side with only the last-formed coil visible, the inner side of the lastformed chambers projecting toward the umbilicus, periphery rounded; chambers distinct, slightly inflated, especially on the ventral side, 9 or 10 in the last-formed coil, of rather uniform shape and increasing only slightly in size as added; sutures distinct, strongly limbate; wall thin, translucent, very finely perforate, shining; aperture at the ventral margin of the last-formed chamber, slightly ventral to the periphery. Length of holotype, $0.32 \mathrm{~mm}$; breadth, $0.2 \mathrm{~mm}$; thickness, $0.12 \mathrm{~mm}$.

The types of this species came from a depth of 12 fathoms off Levuka, Fiji. It also occurs at Rongelab Atoll; 21 fathoms, Guam Anchorage, Ladrone Islands; Port Lotten, Kersail, Caroline Islands; Mokaujar Anchorage, Fiji; and a few Albatross stations in the same general area.

\section{Nonionella lata Cushman and Valentine}

Plate 9, figure 14

Nonionella lata Cushman and Valentine, Stanford Univ., Dept. Geology, Contr., vol. 1, no. 1, p. 20, pl. 7, figs. 5a-c, 1930.

Test trochoid, becoming very broad at the periphery, in peripheral view triangular, thickness nearly equaling the diameter in the adult; chambers 11 to 13 in the adult whorl, low, becoming very thick at the periphery in the adult; sutures distinct, slightly depressed, curved; wall smooth except at the inner portion of 
the sutures, which are finely beaded; aperture at the base of the chamber at the periphery. Length $0.60 \mathrm{~mm}$; breadth $0.60 \mathrm{~mm}$; thickness $0.50 \mathrm{~mm}$.

The types of this species were found off the Channel Islands, Calif. The species is very much inflated in the adult.

\section{Genus CUShMANELLA Palmer and Bermúdez, 1936}

Cushmanella Palmer and Bermúdez, Soc. cubana historia nat. Mem., vol. 9, no. 4, p. 252; 1936.

Nonionina (part) D'Orbigny, in De la Sagra, Historia física, política y natural de la isla de Cuba, Foraminifères, p. $67,1839$.

Test free, hyaline, involute, bilaterally symmetrical; comprising two series of chambers - a large, conspicuous series and a series of small, paired chambers alternating with the large chambers at the umbilical margin. Apertures two, one a narrow opening at the base of the primary chamber and the second a conspicuous oval opening in the septal face approximately two-thirds the distance from the periphery to the base of the chamber.

Within the primary chamber a flattened tube extends from the conspicuous septal aperture diagonally across the chamber to the aperture at the base of the preceding chamber; at the inner end this tube spreads funnel-like, and the enlarged part is attached to the preceding septal face below the septal aperture and extends to the lateral walls of the test. The supplementary partition is very thin and glassy and bears numerous conspicuous perforations, giving it a sievelike appearance. The chamber thus formed by the funnel-like partition communicates with the main chamber cavity only by the sievelike pores, except in some cases in which it appears that the tubular part of the funnel is not entirely closed on the ventral side. The area of the septum included within this supplementary chamber is usually opaque, while the remainder of the septum is transparent.

The secondary series of chambers does not communicate with the exterior but with the primary chambers by a very inconspicuous pore on the outer margin, opening into the supplementary chamber within the primary chamber.

Tertiary and Recent.

The genotype has been subjected to considerable study by Palmer and Bermúdez. The test in this group seems to be bilaterally symmetrical, and the supplementary chambers are equally developed on the two sides. The type species is living off Cuba and is possibly to be found in the Tertiary of that region. Its relationships seem to be with Nonion rather than with the Cassidulinidae.

\section{Cushmanella brownii (D’Orbigny) PaImer and Bermúdez}

\section{Plate 9, figures $15-18$}

Nonionina brownii D'Orbigny, in De la Sagra, Historia física, política y natural de la isla de Cuba, Foraminifères, p. 67, pl. 7, figs. 22, 23, 1839.

Nonion brownii Bermúdez, Soc. cubana historia nat. Mem., vol. 9, no. 3, p. 135, pl. 14, figs. 8, 9, 1935.

Cushmanella brownii Palmer and Bermúdez, Soc. cubana historia nat. Mem., vol. 9, no. 4, p. 253, pl. 22, figs. 1-3, 5, 1936.

Test bilaterally symmetrical, compressed, close-coiled, periphery rounded; chambers distinct, umbilical region on both sides occupied by a series of small supplemen- tary chambers alternating with the primary ones, which increase rapidly in size as added; sutures distinct, slightly depressed and somewhat limbate, slightly sigmoid; wall smooth, translucent, finely perforate; apertures consisting of a low arched opening at the base of the apertural face in the median line and a second narrow, slightly curved opening in the middle of the apertural face, connecting with the aperture of the previous chamber by a funnel-shaped internal tube, the supplementary chambers with a small opening at the periphery connecting with the interior larger chamber adjacent to it. Length up to $1.00 \mathrm{~mm}$; breadth $0.55-0.65 \mathrm{~mm}$; thickness $0.35-0.45 \mathrm{~mm}$.

D'Orbigny's species came from shore sands of Cuba. Through the kindness of Dr. Bermúdez I have had a fine series of Recent specimens of this species for study from the north coast of Cuba and from the late Tertiary on the east bank of the Canimar River 800 meters from its mouth, Matanzas, Cuba.

The development is through such forms as Nonion glabrellum Cushman of the Miocene of Florida. The appearance of the test in the two species is very similar indeed, but in $N$. glabrellum the supplementary chambers are not developed, and the supplementary aperture in the middle of the apertural face often still connects with the base by a narrow curved slit.

\section{Genus ASTRONONION Cushman and Edwards, 1937}

Astrononion Cushman and Edwards, Cushman Lab. Foram. Research Contr., vol. 13, p. 30, 1937.

Nonionina (part) of authors.

Nonion (part) of authors.

Genoholotype Nonionina stelligera D'Orbigny.

Test bilaterally symmetrical, close-coiled in a single plane; chambers consisting of two kinds-large primary ones in the median plane and two other supplementary sets in the umbilical region of either side and alternating with the primary ones, forming a stellate pattern in the center of each side; wall calcareous, finely to coarsely perforate; aperture of the primary chambers at the base of the apertural face of the last-formed chamber, in the supplementary chambers on the periphery of the chamber, elongate, narrow.

Oligocene to Recent.

In some respects this genus resembles Cushmanella, but the supplementary chambers are more strongly developed, with definite exterior apertures. There is no aperture in the middle of the outer wall of the apertural face in Astrononion.

There are evidently other species than those given below, from the published records and figures. The genus so far as known starts in the Oligocene of Australia, but specimens have been recorded by Halkyard from the upper Eocene Blue Marl of Biarritz, France, which may possibly belong here. 
Astrononion stelligerum (D'Orbigny) Cushman and Edwards

Plate 10, figure 1

Nonionina stelligera D'Orbigny, in Barker-Webb and Berthelot, Histoire naturelle des iles Canaries, vol. 2, pt. 2, Foraminifères, p. 128, pl. 3, figs. 1, 2, 1839.

Astrononion stelligerum Cushman and Edwards, Cushman Lab. Foram. Research Contr., vol. 13, p. 31, pl. 3, figs. 7a, b, 1937 .

Test strongly compressed, umbilical region slightly depressed, periphery rounded; chambers of the primary coil distinct, of rather uniform shape, increasing regularly in size as added, slightly if at all inflated, apertural face much higher than broad, supplementary chambers elongate, narrow, very irregularly rhomboid, with a very sharp, distinct angle toward the umbilical end, pointing posteriorly; sutures distinct, rather strongly curved, little if at all depressed, those between the supplementary chambers very distinct; wall smooth, finely perforate; aperture low, arched, opening at the base of the apertural face at the median line. Diameter $0.35-0.50 \mathrm{~mm}$; thickness $0.15-0.20 \mathrm{~mm}$.

The types of this species came from shallow water off the island of Teneriffe, Canary Islands, where D'Orbigny recorded it as very rare. There have been many records referred to this species, both fossil and Recent, by many authors from various parts of the world. A study of these figures seems to show that none of them are identical with the species figured and described by D'Orbigny.

\section{Astrononion sidebottomi Cushman and Edwards}

Plate 10, figure 2

Nonionina stelligera Sidebottom [not D'Orbigny], Manchester Lit. Philos. Soc. Mem. and Proc., vol. 53, no. 21, p. 13, pl. 4, fig. 9, 1909:

Astrononion sidebottomi Cushman and Edwards, Cushman Lab. Foram. Research Contr., vol. 13, p. 31, pl. 3, figs. 8a, b, 1937.

Test somewhat compressed, umbilical region very slightly depressed, periphery rounded, lobulate, apertural face about as high as broad, usually somewhat oblique; chambers 9 or 10 in the primary coil, distinct, much inflated, supplementary chambers elongate, the later ones triangular rather than rhomboid, earlier ones rhomboid; sutures distinct, slightly curved, depressed; wall smooth, distinctly perforate; aperture a low, arched opening at the base of the apertural face, apertures of supplementary chambers at the posterior side, in the earlier ones toward the periphery, in the adult running all the way from the umbilicus to the outer point. Diameter $1.25 \mathrm{~mm}$; thickness $0.55 \mathrm{~mm}$.

The types came from the Bay of Naples.

This species differs from $A$. stelligerum (D'Orbigny) in the much thicker test, broader and triangular supplementary chambers, and lobulate periphery. The species is evidently that recorded by Sidebottom from off the island of Delos and from the bay of Palermo.
It has occurred in material kindly sent to me by $\mathrm{Mr}$. Sidebottom from Delos, and I have specimens also from off Ville Franche, France, and from the bay of Naples.

\section{Astrononion stellatum Cushman and Edwards}

Plate 10, figures 3-5

Astrononion stellatum Cushman and Edwards, Cushman Lab. Foram. Research Contr., vol. 13, p. 32, pl. 3, figs. 9-11, 1937.

Test somewhat compressed, umbilical region slightly depressed, periphery broadly rounded, lobulate, apertural face about as high as broad; chambers 7 or 8 in the adult, strongly inflated, supplementary chambers strongly rhomboid, the outer end in adult very tapering; sutures depressed, strongly curved; wall smooth, distinctly but finely perforate; aperture a low, arched slit at the base of the last-formed chamber, sometimes slightly subdivided, in the supplementary chambers a long, low opening at the posterior peripheral margin.

Diameter $0.60-0.95 \mathrm{~mm}$; thickness $0.25-0.45 \mathrm{~mm}$.

The types of this species were obtained off southern Iceland.

This species differs from $A$. stelligerum (D'Orbigny) in the very rounded apertural face, less compressed test, fewer chambers, and broader supplementary chambers. It is apparently well distributed in the northern portion of the North Atlantic, from around the British Isles northward, where it has probably been recorded as Nonionina stelligera. It differs from the Mediterranean species in the more definitely rhomboid supplementary chambers and fewer primary chambers.

\section{Astrononion viragoense Cushman and Edwards}

Plate 10, figure 6

Astrononion viragoense Cushman and Edwards, Cushman Lab. Foram. Research Contr., vol. 13, p. 32, p]. 3, figs. 12a, b, 1937.

Test somewhat compressed, strongly umbilicate, periphery very broadly rounded, apertural face broader than high, periphery somewhat lobulate; chambers about 7 in the adult, increasing rather rapidly in size as added, very strongly inflated, supplementary chambers very broadly rhomboid, somewhat fused; sutures depressed, strongly curved in the earlier stages, slightly so in the adult, strongly depressed; wall smooth, finely perforate; aperture at the base of the apertural face, subdivided into numerous small openings, those of the supplementary chambers low, at the posterior peripheral side. Diameter $0.60 \mathrm{~mm}$; thickness $0.30 \mathrm{~mm}$.

The types came from Virago Sound, British Columbia.

This species differs from $A$. stelligerum (D'Orbigny) in the fewer chambers, which are strongly inflated, the very broad supplementary chambers, and the subdivided aperture. It differs from the two species previously described in the fewer chambers, very broad apertural face, and subdivided aperture. 


\section{Astrononion fijiense Cushman and Edwards}

Plate 10, figures 9, 10

Nonionina asterizans H. B. Brady [not Fichtel and Moll], Challenger Rept., Zoology, vol. 9, pl. 109, figs. 1, 2, 1884.

Astrononion fijiense Cushman and Edwards, Cushman Lab. Foram. Research Contr., vol. 13, p. 35, pl. 3, figs. 15, 16, 1937.

Test much compressed, umbilical regions flattened or slightly depressed, periphery rounded; chambers of the primary coil numerous, about 12 in the adult coil, of uniform shape, increasing very gradually in size as added, supplementary chambers small, roughly rhomboid, alternating with the primary ones; sutures distinct, slightly curved in the primary coil, slightly depressed and somewhat limbate, those of the supplementary chambers less distinct; wall coarsely perforate; aperture a low opening in the median line at the base of the apertural face, in the supplementary chambers at the posterior peripheral side. Diameter $0.80 \mathrm{~mm}$; thickness $0.35 \mathrm{~mm}$.

This species differs from $A$. stelligerum (D'Orbigny) in the greater number of chambers, very short and somewhat fused supplementary chambers, and very coarsely perforate wall. Brady's Challenger specimens were found off Fiji.

\section{Astrononion tumidum Cushman and Edwards}

Plate 10, figure 11

Nonionina stelligera (part) H. B. Brady [not D'Orbigny], Challenger Rept., Zoology, vol. 9, p. 728, pl. 109, fig. 5, 1884. Astrononion tumidum Cushman and Edwards, Cushman Lab. Foram. Research Contr., vol. 13, p. 33, pl. 3, fig. 17, 1937.

Test somewhat depressed, periphery broadly rounded, lobulate, umbilical regions depressed; chambers of the primary coil 6 or 7 , inflated, of uniform shape, increasing gradually in size as added, supplementary chambers elongate, rhomboid, the outer ends elongate, tapering; sutures distinct, depressed, slightly curved; wall smooth, finely perforate; aperture of the supplementary chan:bers along the posterior peripheral margin. Diameter $0.60 \mathrm{~mm}$.

Brady's figured specimen came from Challenger station 344, in 420 fathoms, off Ascension Island, in the South Atlantic.

This species has fewer and more tumid chambers than $A$. stelligerum (D'Orbigny), and its supplementary chambers are much more regularly rhomboid and larger. It differs from $A$. viragoense, which it most closely resembles, in the much more tapering supplementary chambers.

\section{Astrononion novo-zealandicum Cushman and Edwards}

\section{Plate 10, figure 12}

Astrononion novo-zealandicum Cushman and Edwards, Cushman Lab. Foram. Research Contr., vol. 13, p. 35, pl. 3, figs. $18 \mathrm{a}, \mathrm{b}, 1937$.
Test slightly compressed, umbilicate, periphery nearly entire, very slightly umbilicate, in later portion broadly rounded, apertural face somewhat broader than high; chambers distinct, about 10 in the adult coil, slightly if at all inflated, increasing very gradually in size as added, supplementary chambers elongate, tubular, of rather uniform diameter throughout; sutures very slightly if at all depressed; wall smooth, coarsely perforate; aperture at the base of the apertural face, low, arched, those of the supplementary chambers semicircular at the outer end. Diameter $1.10 \mathrm{~mm}$; thickness $0.60 \mathrm{~mm}$.

The types were collected off New Zealand.

\section{Astrononion italicum Cushman and Edwards}

Plate 10, figures 13, 14

Astrononion italicum Cushman and Edwards, Cushman Lab. Foram. Research Contr., vol. 13, p. 35, pl. 3, figs. 19, 20, 1937.

Test somewhat compressed, umbilicate, periphery somewhat lobulate, broadly rounded, apertural face about as broad as high; chambers distinct, 10 to 12 , increasing very gradually in size as added, slightly if at all inflated, supplementary chambers elongate, generally tubular but more or less tapering toward the outer end; sutures distinct, slightly limbate, very slightly depressed, gently curved; wall thick, coarsely perforate; aperture at the base of the apertural face, low, sometimes slightly divided, in the supplementary chambers elongate, very oblique, at the posterior side at the peripheral end. Diameter up to $1.25 \mathrm{~mm}$; thickness $0.60 \mathrm{~mm}$.

The types came from the Pliocene clays of Coroncina, near Siena, Italy.

This species differs from $A$. stelligerum (D'Orbigny) in the larger number of chambers and very narrow, tubular supplementary chambers, with oblique apertures.

In some of the specimens of this species there are apparently supplementary apertures in the face of the primary chambers, connecting with the supplementary chambers by a tubular canal. Somewhat similar features were noted in A. australe Cushman and Edwards.

\section{Astrononion australe Cushman and Edwards}

Plate 10, figures 7, 8

Astrononion australe Cushman and Edwards, Cushman Lab. Foram. Research Contr., vol. 13, p. 33, pl. 3, figs. 13, 14, 1937.

Test compressed, periphery broadly rounded, slightly lobulate, the apertural face slightly higher than broad, umbilical region slightly depressed; chambers distinct, usually arched in the adult, somewhat inflated, increasing rather regularly in size as added, supplementary chambers in the adult irregularly rhomboid, in early stages somewhat tubular; wall smooth, distinctly perforate; aperture a low opening at the base of the 
apertural face, in the supplementary chambers forming a narrow, semielliptical opening, placed obliquely at the posterior side, near the periphery. Diameter $0.90-$ $1.10 \mathrm{~mm}$; thickness $0.25-0.40 \mathrm{~mm}$.

The types came from the Oligocene Balcombian of Muddy Creek, Victoria, Australia.

This species differs from $A$. stelligerum (D'Orbigny) in the more lobulate periphery, broader apertural face, and completely covered umbilical region. It differs from most of the other species above described in the more tubular supplementary chambers of the earlier stages and the more arched aperture. This species occurs also in the Miocene of Filter Quarries, Victoria, Australia, and in the lower Pliocene of Beaumaris, near Melbourne, Victoria. In some respects it resembles D'Orbigny's figure of $A$. stelligerum more than most of the other forms that had been referred to that species, but there are many points of difference between the two.

\section{Genus ELPHIDIUM Montfort, 1808}

Elphidium Montfort, Conchyliologie systématique, vol. 1, p. 15, 1808.

Meek and Hayden, Smithsonian Contr., no. 172, p. 13, 1864.

Cushman, Cushman Lab. Foram. Research Contr., vol. 3, pp. 49, 169, 1927.

Cushman and Grant, San Diego Soc. Nat. History Trans., vol. 15, no. 6, pp. 71-73, 1927.

Cushman, Cushman Lab. Foram. Research Special Pub. 1, p. 205, 1928; U. S. Nat. Mus. Bull. 104, pt. 7, p. 17, 1930; Cushman Lab. Foram. Research Special Pub. 4, p. 193, 1933; U. S. Nat. Mus. Bull. 161, pt. 2, p. 46, 1933.

Geophonus Montfort, Conchyliologie systématique, vol. 1, p. 19, 1808 (genoholotype, Nautilus macellus Fichtel and Moll (part)).

Pelorus Montfort, Conchyliologie systématique, vol. 1, p. 23, 1808 (genoholotype, Nautilus ambiguus Fichtel and Moll (part)).

Andromedes Montfort, Conchyliologie systématique, vol. 1, p. 39, 1808 (genoholotype, Nautilus strigillatus Fichtel and Moll (part)).

Sorilus Montfort, Conchyliologie systématique, vol. 1, p. 43, 1808 (genoholotype, Nautilus strigillatus Fichtel and Moll (part)).

Themeon Montfort, Conchyliologie systématique, vol. 1, p. 203, 1808 (genoholotype, Themeon rigatus Montfort?= Nautilus crispus Linnaeus).

Cellanthus Montfort, Conchyliologie systématique, vol. 1, p. 207, 1808 (genoholotype, Nautilus craticulatus Fichtel and Moll).

Vorticialis Lamarck, Extrait du cours de zoologie, p. 122, 1812 (genotype, by designation, Nautilus craticulatus Fichtel and Moll).

Polystomella Lamarck, Histoire des animaux sans vertèbres, vol. 7, p. 625, 1822 (genotype by designation, Nautilus crispus Linnaeus).

Robulina (part), Münster, 1838.

Geoponus Ehrenberg, K. preuss. Akad. Wiss. Abh. 1839, p. 132, 1841 (genoholotype, Geoponus stella-borealis Ehrenberg). Nonionina (part), Boll, 1846.

Helicozoa Moebius, Beitr. Meeresfauna Insel Mauritius, p. 103, 1880 (genoholotype, Nautilus craticulatus Fichtel and Moll).

Genotype, Nautilus macellus Fichtel and Moll.

Test typically planispiral, bilaterally symmetrical, mostly involute; chambers numerous, with distinct sutures, either depressed, or raised and limbate, with septal bridges and depressions; wall calcareous, perforate; apertures one or more at the base of the apertural face. Eocene to Recent.

The pre-Tertiary records for this genus are considered below. It seems evident from a study of a large amount of material that the genus Elphidium developed directly from Nonion in early Eocene time. In the early species the retral processes are very short and the pores along the sutures small. If we discard Terquem's one species from the middle Eocene, which may be from contaminated material, all the Eocene and most of the Oligocene species show these characters.

There is a progressive development of larger openings over the sutures and more highly developed retral processes until such specialized species as Elphidium craticulatum and true $E$. striato-punctatum are found in warm, shallow waters of tropical seas in the IndoPacific. Such species have large umbilical bosses with pores leading to the interior. Most species have rather definite ranges, and few of them are long-lived, so that they should make good index fossils for the Tertiary.

\section{Pre-Tertiary records for "Polystomella"}

There are several records for "Polystomella" from Triassic, Jurassic, and Cretaceous rocks, but probably none of these really represent material from those formations. The figures given would seem to indicate that possibly there was a contamination of material and that the Polystomellas came from other sources. The oldest records are those given by Vadász, who records "Polystomella crispa" from the Triassic (?) of Bakony, Austria, ${ }^{6}$ and he records "Polystomella" macella (Fichtel and Moll) from the same locality. ${ }^{7}$ The figures in both cases evidently are of Elphidium, but it is exceedingly doubtful if these came from the Triassic. Other forms recorded from this same material rather confirm this view. From the middle Jurassic of Callovien, Austria, Uhlig ${ }^{8}$ records "Polystomella" fichteli D'Orbigny. In this case, also, the figured specimen is very definitely an Elphidium. Terquem describes a species, "Polystomella" metensis, from the Liassic of St.-Julien-les-Metz, France. ${ }^{9}$ Again the figure is definitely an Elphidium, but the records should be questioned from what is known of Jurassic material. Gümbel ${ }^{10}$ describes a species, "Polystomella" (?) polypora, from the upper Jurassic of Germany, but his specimen is evidently a Marginulina. These complete the records for the pre-Cretaceous, and as none of the material that I have been able to ex-

6 Vadász, Elemér, Resultät der wissenschaftlich en Erforschung des Balaton-Sees, vol. 1, pt. 1, Anhang Pal., vol. 1, no. 1, p. 35, pl. 2, fig. 15, 1911.

7 Idem, fig. 16

\& Uhlig, Victor, Ueber Foraminiferen aus dem rjäsan'schen Ornatenthone, K.-k. geol. Reichsanstalt Jahrb., vol. 33, p. 773, pl. 8, g. 7, 1883.

Q Terquem, Olry, Mémoire sur les Foraminifères du Lias du Département de la Moselle: Acad. imp. Metz Mém., vol. 39, p. 628, pl. 4, figs. 7a, b, 1858.

10 Gumbel, C. W., Die Streitberger Schwammlager und ihre Foraminiferen-Einschliusse: Ver. vaterl. Naturkunde Wïrttemberg. Jahresheft, Jahrg. 18, p. 231, pl. 4, fig. 6,1862 . 
amine shows any sign of the genus, it would seem probable that all these records are based upon material which has somehow been wrongly identified as to age or upon collections in which erratic specimens appear through contamination.

From the Cretaceous, there are also a few records. Three species are recorded by Michelotti from the upper Cretaceous of Italy. None of the figures accompanying these records, however, are very definitely Elphidium, and some of them are very clearly not that genus. The records are as follows: "Polystomella" crispa Linnaeus, "Polystomella" laevigata Michelotti, ${ }^{12}$ "Polystomella" rotula Michelotti, ${ }^{13}$ "Polystomella" savii Michelotti. ${ }^{14}$ Burrows, Sherborn, and Bailey ${ }^{15}$ record "Polystomella" macella (Fichtel and Moll) from England. Their figure is rather indefinite but has somewhat the appearance of Elphidium. The one very definitely known Elphidium from the Cretaceous is that figured by Olszewski, "Polystomella" karreri Olszewski ${ }^{16}$ from the Cretaceous of Hungary. It is to be suspected that this species, also, may have gotten into Olszewski's material from contamination. There are a few other references for the genus from the Cretaceous, but they are not accompanied by figures.

Owing to the fact that none of our material has yielded any specimens of true Elphidium older than the middle Eocene, it seems probable that all the foregoing records should be viewed with suspicion, and they certainly need confirmation before the occurrence of Elphidium earlier than the Tertiary can be accepted.

\section{Elphidium costiferum (Terquem) Cushman}

Plate 10, figure 15

Polystomella costifera Terquem, Soc. géol. France Mém., sér. 3, vol. 2, p. 47 , pl. 2 (10), figs. $26 \mathrm{a}, \mathrm{b}, 1882$.

Terquem described this species from the Eocene of the Paris Basin at Vaudancourt as very rare. I have failed to find any specimens in a fairly large sample from the type locality. A copy of the type figure is given on plate 10 . It shows a species with heavy, thickened, raised sutures, strongly curved, the retra] processes elongate, periphery keeled, and the test biumbilicate. There seem to be no further records for the species.

The figures of this species show that it is unlike any of the other Eocene species, all of which are primitive, with very short retral processes. It therefore should perhaps be suspected that the record is open to some question, and the possibility of a mixing of material should be considered.

\footnotetext{
11 Michellotti, Giovanni, Saggio storico dei Rizopodi caratteristici dei Terren sopracretacei: Soc. italiana sci. nat. Atti, vol. 22, p. 287, pl. 1, fig. 8, 1841

12 Idem, p. 288, pl. 2, fig. 7.

13 Idem, p. 288, pl. 2, fig. 8 .

14 Idem, p. 287, pl. 1, fig. 7

15 Burrows, W. H., Sherborn, C. D., and Bailey, George, The foraminifera of the Red chalk of Yorkshire, Norfolk, and Lincolnshire: Royal Micr. Soc. Jour., 1890, p. 563 , pl. 11, figs, $26 \mathrm{a}$, b.

16 Olszewski, Stanislaus, Zapiski paleontologiczne: Akad. umiej. Krakowie, Sprawozd. Kom. Fizyj., vol. 9, p. 128, pl. 2, fig. 4, 1875.
}

\section{Elphidium latidorsatum (Reuss) Cushman}

Plate 10, figure 16

Polystomella latidorsata Reuss, Akad. Wiss. Wien Denkschr., vol. 23, p. 10, pl. 1, fig. 16, 1864; Akad. Wiss. Wien Sitzungsber., vol. 59 , pt. 1 , p. $465,1869$.

Reuss described this species from the upper Eocene of Oberburg, Steiermark, and later recorded it from the Oligocene of Gaas. I have had no material that could be referred to it, although I have examined material from Gaas and upper Eocene material similar in age to that from which Reuss' type came.

A copy of the original type figure is given on plate 10 for reference. As in most other Eocene species of the genus, the retral processes are short and the pores very small.

\section{Elphidium texanum (Cushman and Applin) Cushman}

$$
\text { Plate 10, figure } 17
$$

Polystomella texana Cushman and Applin, Am. Assoc. Petroleum Geologists Bull., vol. 10, p. 184, pl. 10, figs. 7-9, 1926. Elphidium texanum Cushman, U. S. Geol. Survey Prof. Paper 181, p. 32, pl. 12, figs. 5a-c, 1935.

Test nearly circular in outline, the periphery broadly rounded, slightly umbonate; chambers distinct, usually 11 in the adult coil, of nearly uniform size; sutures distinct, slightly depressed, strongly curved, retral processes only slightly developed; wall smooth; aperture a low arched slit at the base of the ventral face of the last-formed chamber. Diameter $0.45 \mathrm{~mm}$; thickness $0.20 \mathrm{~mm}$.

The type specimens of this species came from the Jackson Eocene in Ohio and Red River well 2, Tyler County, Tex., at a depth of 537 feet.

The retral processes are not highly developed, and young specimens are difficult to distinguish from Nonion. It has not been recorded from the area east of Texas. Specimens were collected by Alexander Deussen in outcrop material of the Jackson in a bluff on Atascosa Creek near the old Whitsett ranch house, in Atascosa County, Tex., U. S. G. S. station 6148.

\section{Elphidium eocenicum Cushman and Ellisor}

\section{Plate 10, figure 18}

Elphidium eocenicum Cushman and Ellisor, Cushman Lab. Foram. Research Contr., vol. 7, p. 53, pl. 7, figs. 6a, b, 1931.

Ellisor, Am. Assoc. Petroleum Geologists Bull., vol. 17. pl. 2, figs. 13a, b, 1933.

Test small, biconvex, periphery broadly rounded, the umbilical region slightly depressed; chambers distinct, somewhat inflated, typically 8 in the lastformed coil, of rather uniform size and shape; sutures distinct, depressed, very slightly curved, retral processes distinct, usually 9 or 10 visible along each suture in side view; wall smooth, finely perforate; aperture consisting of several small pores along the base of the 
apertural face. Diameter $0.30 \mathrm{~mm}$; thickness 0.10 $0.12 \mathrm{~mm}$.

The types of this species came from the upper Eocene Jackson, in the northeast corner of survey 27, jurisdiction of Mier, Starr County, Tex.

The species is in some respects close to Elphidium minutum (Reuss), from the Oligocene of Europe, but it has more depressed sutures and the pores are smaller.

\section{Elphidium smithi Cushman and Dusenbury}

Plate 10, figure 19

Elphidium smithi Cushman and Dusenbury, Cushman Lab. Foram. Research Contr., vol. 10, p. 61, pl. 8, figs. 7a, b, 1934.

Test of medium size, completely involute, slightly umbonate, the diameter about twice as great as the thickness, periphery. narrowly rounded to subacute; chambers numerous, 16 to 18 in the last-formed coil; sutures distinctly curved and depressed, retral processes very numerous, usually appearing as a double line of minute, irregularly spaced pores; wall smooth, polished, and very finely perforate. Diameter $1.00 \mathrm{~mm}$; thickness $0.50 \mathrm{~mm}$.

The types of this species came from the Eocene Poway conglomerate of Murray Canyon, La Jolla quadrangle, San Diego County, Calif.

This is a somewhat larger species than $E$. schencki and has more chambers to a coil. The more strongly curved sutures and the retral processes with their series of double pores make it distinct from any of the known early Tertiary forms. In addition to its occurrence at the type locality it is abundant and reaches greater size in material collected by C. C. Church from the type Tejon of Live Oak Creek, Kern County, Calif.

\section{Elphidium schencki Cushman and Dusenbury}

\section{Plate 10, figure 20}

Elphidium schencki Cushman and Dusenbury, Cushman Lab. Foram. Research Contr., vol. 10, p. 60, pl. 8, figs. 8a, b, 1934.

Test small, close-coiled, thick, the thickness about two-thirds the diameter, periphery broadly rounded; chambers comparatively few, 6 or 7 in the adult coil, very slightly inflated; sutures in the adult very slightly depressed, slightly curved, retral processes single, numerous; wall finely perforate. Diameter $0.55 \mathrm{~mm}$; thickness $0.40 \mathrm{~mm}$.

The types of this species came from the Eocene Poway conglomerate of Murray Canyon, La Jolla quadrangle, San Diego County, Calif.

The species somewhat resembles $E$. eocenicum Cushman and Ellisor but is completely involute, much thicker, and with sutures very slightly if at all depressed, while in $E$. eocenicum the sutures are very distinctly depressed and the chambers are somewhat inflated.
Elphidium sp. (?)

Plate 10, figure 21

Elphidium sp. Howe and Wallace, Louisiana Dept. Cons. Geol. Bull. 2, p. 50, pl. 9, fig. 6, 1932.

Several broken specimens of Elphidium were found in the upper horizon [Jackson Eocene] at Danville [La.]. The test is subcircular in outline, periphery broadly rounded; chambers numerous, about 18 in the last-formed whorl; sutures more or less distinct, bridged by septal ridges; umbilical area with a large, prominent boss; wall calcareous, perforate. Diameter $0.56 \mathrm{~mm}$.

The above description is copied from Howe and Wallace, and a copy of their figure is given on plate 10 . The species should be looked for in the general Jackson Eocene of the Coastal Plain region, and the characters more fully described.

\section{Elphidium minutum (Reuss) Cushman}

Plate 10, figures 22-25

Polystomella minuta Reuss, Akad. Wiss. Wien Sitzungsber., vol. 50, pt. 1, p. 478, pl. 4, figs. 6a, b, 1864 [1865].

Hosius, Naturwiss. Ver. Osnabrück Jahrb., 1893-94, p. 179, 1895.

Polystomella discrepans Reuss, op. cit., p. 478, pl. 4, figs. 7a, b.

Test compressed, periphery rounded, umbilical areas slightly depressed; chambers distinct, slightly inflated, of uniform shape, increasing very slightly in size as added, 10 to 14 chambers in the adult coil; sutures slightly depressed, curved, retral processes very slightly developed, pores very small, 6 to 8 visible along the suture in side view; aperture consisting of small rounded openings along the base of the apertural face. Diameter $0.40-0.50 \mathrm{~mm}$; thickness $0.18-0.25 \mathrm{~mm}$.

The types of this species came from the upper Oligocene of Germany. The figured specimens were collected near Dickholzen, near Hildesheim, Province of Hannover, Germany. The differences in thickness and number of chambers between the two species described by Reuss are bridged over in our series of specimens, and the two are here considered a single species.

\section{Elphidium subnodosum (Münster) Cushman}

Plate 11, figure 2

Robulina subnodosa Münster, in Roemer, Neues Jahrb., 1838, p. 391, pl. 3, fig. 61 .

Polystomella subnodosa Reuss, Akad. Wiss. Wien Sitzungsber., vol. 18, p. 240, pl. 4, figs. 51a, b, 1855 [1856]; vol. 50, pt. 1, p. 478, 1864; Akad. Wiss. Wien Denkschr., vol. 25, p. 164, 1865.

Hosius, Naturwiss. Ver. Osnabruck Jahrb., 1893-94, p. 179, 1895.

Franke, Mus. Natur- und Heimatkunde und Naturwiss. Ver. Magdeburg Abh. und Ber., Band 4, Heft 2, p. 189, pl. 6, figs. 72a, b, 1925.

Test much compressed, biumbonate, rhomboid in peripheral view, periphery subacute, slightly keeled, later portion lobulate; chambers distinct, about 15 in the adult coil, of rather uniform shape, increasing slightly in size as added; sutures distinct, sharply incised, 
slightly curved, retral processes short and somewhat indistinct, about 10 to a chamber in the adult; wall smooth and polished, the umbones with large, scattered pores; aperture consisting of numerous small, rounded openings at the base of the apertural face. Diameter $1.25-1.50 \mathrm{~mm}$; thickness $0.60-0.70 \mathrm{~mm}$.

This is a fine, large species of the middle and upper Oligocene of central Europe. The specimen figured came from Astrupp, near Osnabrück, Germany. The above references evidently represent typical material.

There are many other records, most of which are based on Brady's Challenger figures, which are not the same as the Oligocene form.

\section{Elphidium crespinae Cushman}

Plate 11, figure 1

Elphidium crespinae Cushman, Cushman Lab. Foram. Research Contr., vol. 12, p. 78, pl. 14, figs. $1 \mathrm{a}, \mathrm{b}, 1936$.

Test much compressed, sides flattened, nearly parallel, umbilical regions flattened, not excavated, periphery acute but not keeled; chambers distinct, numerous, 16 to 18 in the final coil, narrow, curved; sutures distinct, strongly curved, sharply elevated, retral processes distinct, extending nearly across the chamber, 12 to 15 in the adult chamber; wall almost completely covered by the raised sutures and retral processes; aperture consisting of a few small, rounded openings at the base of the apertural face, which is elongate and narrowly triangular. Diameter $0.50 \mathrm{~mm}$; thickness $0.10 \mathrm{~mm}$.

The types came from Oligocene Brown marl, lower beds of Muddy Creek, near Hamilton, Victoria, Australia.

\section{Elphidium crassatum Cushman}

Plate 11, figure 3

Elphidium crassatum Cushman, Cushman Lab. Foram. Research Contr., vol. 12, p. 81, pl. 14, figs. 8 a, b, 1936.

Test strongly compressed, very slightly umbonate, sides flattened in the middle and umbo not projecting, periphery acute, slightly keeled; chambers distinct, numerous, about 20 in the adult coil, of uniform shape, increasing very gradually in size, not inflated; sutures distinct, raised, strongly sigmoid, retral processes sharply raised, running clear across the chambers, about 15 in the adult chamber; wall covered by a raised reticulation of sutures and retral processes; aperture consisting of several small, rounded openings at the base of the sharply triangular apertural face. Diameter $0.70 \mathrm{~mm}$; thickness $0.20 \mathrm{~mm}$.

The types came from the Oligocene Brown marl, lower beds, Muddy Creek, Victoria, Australia.

\section{Elphidium howchini Cushman}

Plate 11, figure 4

Elphidium howchini Cushman, Cushman Lab. Foram. Research Contr., vol. 12, p. 79, pl. 14, figs. 2a, b, 1936.
Test compressed, sides flattened, sides nearly parallel, umbilical regions somewhat raised, periphery rounded; chambers distinct, 12 to 15 in the adult coil, curved; sutures distinct, very thin and highly elevated, strongly curved, retral processes distinct, high, 6 to 8 in the adult chamber; wall ornamented with a deep reticulation made by the highly elevated sutures connected by the platelike retral processes; aperture obscure. Diameter $0.85 \mathrm{~mm}$; thickness $0.25 \mathrm{~mm}$.

The types of this species came from the Oligocene Balcombian of Clifton bank, Muddy Creek, near Hamilton, Victoria, Australia.

\section{Elphidium panamense Cushman}

Plate 11, figure 5

Elphidium panamense Cushman, Cushman Lab. Foram. Research Contr., vol. 12, p. 79, pl. 14, figs. 3a, b, 1936.

Test somewhat compressed, rhomboid in peripheral view, greatest thickness near the umbilicus, thence tapering to the acute periphery, which is slightly keeled, umbilici very slightly depressed, not excavated; chambers distinct, comparatively few, 7 or 8 in the adult coil, curved, increasing very slightly in height; sutures distinct, curved, raised and thickened, retral processes short and low, about 10 in the adult chamber; aperture obscure. Diameter $0.40 \mathrm{~mm}$; thickness $0.20 \mathrm{~mm}$.

The type specimens came from the Oligocene upper part of the Culebra, 200 yards south of south end of switch at Bohio Ridge station, relocated line of Panama Railroad, Panama Canal Zone.

\section{Elphidium culebrense Cushman}

Plate 11, figure 6

Elphidium culebrense Cushman, Cushman Lab. Foram. Research Contr., vol. 12, p. 80, pl. 14, figs. 4a, b, 1936.

Test compressed, elongate, elliptical in peripheral view, periphery rounded, umbilical regions umbonate; chambers fairly distinct, not inflated, slightly curved, 14 to 16 in the adult whorl, increasing very slightly in height as added; sutures distinct, slightly depressed, retral processes very short, not raised, 7 or 8 in the adult chamber; wall smooth; aperture consisting of several rounded openings at the base of the semielliptical apertural face. Diameter $0.65 \mathrm{~mm}$; thickness $0.25 \mathrm{~mm}$.

The types came from the Oligocene upper part of the Culebra, 200 yards south of south end of switch at Bohio Ridge station, relocated line of Panama Railroad, Panama Canal Zone.

\section{Elphidium pseudoinflatum Cushman}

\section{Plate 11, figure 8}

Elphidium pseudoinflatum Cushman, Cushman Lab. Foram. Research Contr., vol. 12, p. 80, pl. 14, figs. 5a, b, 1936.

Test somewhat compressed, rhomboid in peripheral view, periphery acute, slightly keeled, somewhat 
umbilicate; chambers fairly distinct, few, 7 or 8 in the adult coil, rapidly increasing in height and size, not inflated; sutures of early portion indistinct, later becoming more distinct and slightly raised, curved, retral processes of earlier portion extending across the whole chamber and raised, later shorter and less raised; wall ornamented with a reticulate raised network except the final chambers, which are nearly smooth; aperture a series of small, rounded openings at the base of the broadly triangular apertural face. Diameter $0.65-0.75 \mathrm{~mm}$; thickness $0.45 \mathrm{~mm}$.

The types came from the Oligocene Lepidocyclina limestone, Batesford, Victoria, Australia.

\section{Elphidium subplanatum Cushman}

Plate 11, figure 7

Elphidium subplanatum Cushman, Cushman Lab. Foram. Research Contr., vol. 12, p. 82, pl. 14, figs. 11a, b, 1936.

Test strongly depressed, sides in peripheral view nearly parallel, central area with a large circular area with numerous papillae of uniform size, periphery subacute, not definitely keeled; chambers distinct, numerous, 20 to 22 in the adult coil, of rather uniform shape and size; sutures distinct, limbate, slightly raised, curved, retral processes extending across the chamber, 8 to 10 in the adult chamber, slightly raised; wall in the center papillate, the remainder with a low reticulation; aperture consisting of a series of small openings at the base of the triangular apertural face. Diameter $0.70 \mathrm{~mm}$; thickness $0.20 \mathrm{~mm}$.

The types came from the upper Oligocene near Dickholzen, Hildesheimer Wald, Province of Hannover, Germany.

\section{Elphidium hauerinum (D'Orbigny) Cushman}

Plate 11, figure 9

Polystomella hauerina D'Orbigny, Foraminifères fossiles du bassin tertiaire de Vienne, p. 122, pl. 6, figs. 1, 2, 1846.

Test somewhat compressed, periphery broadly rounded, slightly lobulate, sides flattened or slightly depressed at the umbilici; chambers distinct, slightly inflated, of rather uniform shape and size, about 11 in the adult coil; sutures distinct, slightly depressed, nearly radial or slightly curved, retral processes extending about one-third across the diameter, 6 or 7 in the adult chamber; wall smooth except for the retral processes; aperture a series of small rounded openings at the base of the apertural face. Diameter $0.50 \mathrm{~mm}$; thickness $0.22 \mathrm{~mm}$.

The types of this species are from the Miocene of Nussdorf, near Vienna, Austria. Our figured specimen is a topotype. This seems to be a distinctive species in the Vienna Basin but is so far as known restricted to that area. I have specimens also from WienerNeustadt and Heiligenstadt, both near Vienna.

\section{Elphidium rugosum (D'Orbigny) Cushman}

Plate 11, figures 10, 11

Polystomella rugosa D'Orbigny, Foraminifères fossiles du bassin tertiaire de Vienne, p. 123, pl. 6, figs. 3, 4, 1846.

Fornasini, Accad. sci. Ist. Bologna Mem., ser. 5, vol. 7, p. 17 (653), 1899

Polystomella obtusa D’Orbigny, op. cit., p. 124, pl. 6, figs. 5, 6.

Karrer, Akad. Wiss. Wien Sitzungsber., vol. 58, pt. 1, p. 191, 1868.

Fornasini, op. cit., p. 15 (651).

Test much compressed, usually slightly umbilicate, periphery rounded, little if at all lobulate; chambers numerous, 16 to 20 in the adult coil, of rather uniform shape, increasing very slowly in size as added; sutures distinct, slightly curved, retral processes very distinct, covering one-half or more of the width of the chamber, numerous, 12 or more in the adult chamber; wall smooth except for the retral processes; aperture a series of minute openings along the base of the apertural face. Diameter $0.60-0.75 \mathrm{~mm}$; thickness $0.25-0.40 \mathrm{~mm}$.

The types of this species came from Baden, near Vienna, Austria. A topotype is here figured. In addition I have material from Heiligenstadt, near Vienna. Karrer records the species from Kostej, in the Banat region of Hungary, and Fornasini from the Miocene of Calabria, Italy.

I have been unable to distinguish between $E$. rugosum and $E$. obtusum of D'Orbigny, and our series of specimens seem to cover both forms with intermediates.

\section{EIphidium fichtellianum (D'Orbigny) Cushman}

Plate 11, figure 12

Polystomella fichtelliana D'Orbigny. Foraminifères fossiles du bassin tertiaire de Vienne, p. 125, pl. 6, figs. 7, 8, 1846.

Reuss, Deutsche geol. Gesell. Zeitschr., vol. 3, p. 155, 1851; Akad. Wiss. Wien Sitzungsber., vol. 39, p. 211, 1860.

Karrer, Novara-Exped., Geol. Theil, vol. 1, pt. 2, p. 83, pl. 16, fig. 15, 1865 .

Reuss, Akad. Wiss. Wien Sitzungsber., vol. 55, pt. 1, p. 106, 1867.

Karrer, Akad. Wiss. Wien Sitzungsber., vol. 58, pt. 1, p. 191, 1868.

Terquem, Soc. géol. France Mém., sér. 3, vol. 1, p. 15, 1878.

Walther, Zool. Sta. Neapel Mitt., vol. 8, pt. 2, p. 384, pl. 20 , figs. $9 a, b, 1888$.

Fornasini, Accad. sci. Ist. Bologna Mem., ser. 5, vol. 7, p. 11 (647), 1899.

Toula, K.-k. geol. Reichsanstalt Jahrb., vol. 64, p. 642, 1914 [1915].

Polystomella tenuissima Karrer, Novara-Exped., Geol. Theil, p. 83, pl. 16, fig. 16, 1864.

Test strongly compressed, slightly depressed at the umbilici, periphery acute but not keeled, not lobulate; chambers distinct, numerous, about 18 in the adult coil, of uniform shape, increasing very slightly in size as added; sutures distinct, strongly curved, retral processes numerous, extending nearly across the chambers, 12 to 15 in the adult chamber; wall strongly reticulate, owing to the costae and retral processes; aperture low at the base of the apertural face, usually divided into small 
openings. Diameter $0.60-0.75 \mathrm{~mm}$; thickness $0.10 \mathrm{~mm}$.

The types of this species were found in the Miocene of Nussdorf, near Vienna, Austria. The specimen here figured is a topotype. The species is widely distributed in the Miocene, particularly of central Europe, occurs in the Pliocene of southern Europe, and is apparently now living in the Mediterranean.

Our collections include the following localities for this species: Miocene, Nussdorf, Vöslau, Kalksburg, Holuluca, Rausnitz, Gainfarm, Baden, Imendorf, Perchtoldsdorf, and Kattowitz, all in Austria; Ortenburg, Germany; near Loretto, Italy. Burdigalien supérieur, Point Gourguet, Saucats, France. Aquitanien supérieur, St. Arit, near Mont de Marsan, and La Bréde, Larriey, France; Wadi Riena, Egypt. Pliocene, Castel Arquato; Girgenti; Zankleano Gravitelli, near Messina, Italy; Kar Nicobar.

\section{Elphidium flexuosum (D'Orbigny) Cushman}

Plate 11, figure 13

Polystomella flexuosa D'Orbigny, Foraminifères fossiles du bassin tertiaire de Vienne, p. 127, pl. 6, figs. 15, 16, 1846.

Reuss, Akad. Wiss. Wien Denkschr., vol. 1, p. 370, pl. 48 , fig. 3, 1850.

Test somewhat compressed, biumbonate, periphery entire, with a thick, blunt keel; chambers distinct, numerous, about 18 in the adult coil, of uniform shape, increasing very gradually in size as added; sutures distinct, slightly curved, retral processes short but distinct, about 10 in the adult chamber, extending onethird or one-half the distance across the adult chamber; wall smooth except for the retral processes; aperture a series of elliptical openings at the base of the apertural face. Diameter $0.90 \mathrm{~mm}$; thickness $0.35 \mathrm{~mm}$.

The types of this species came from the Miocene of the Vienna Basin, where D'Orbigny records it from both Nussdorf and Baden. There are records for the species from the Miocene of central Europe, Pliocene of Italy, and living off Naples. Not all the figures given resemble the typical form, however.

In our collections the species is represented from the following localities: Miocene, Nussdorf, Vöslau, Holuluca, Gainfarm, Loos, and Kalksburg, Austria. Burdigalien supérieur, Merignac, Gironde, France; Gebel Murr, Egypt. Pliocene, Monte Mario, near Rome, Italy.

The species is thick walled and highly polished and has a very distinctive appearance.

\section{Elphidium antoninum (D'Orbigny) Cushman}

Plate 11, figure 14

Polystomella antonina D'Orbigny, Foraminifères fossiles du bassin tertiaire de Vienne, p. 128, pl. 6, figs. 17, 18, 1846.

Polystomella listeri D'Orbigny, idem, p. 128, pl. 6, figs. 19-22.

Test somewhat compressed, umbilical regions depressed, sometimes with small bosses, periphery broadly rounded, slightly lobulate, chambers distinct, slightly inflated, of uniform shape and with little increase in size as added, about 12 in the adult coil; sutures distinct, slightly depressed, slightly curved, retral processes rather short, about 10 in the adult chamber; wall smooth except for the retral processes and polished; aperture a low opening at the base of the lastformed chamber, often subdivided. Diameter $0.60-0.70$ $\mathrm{mm}$; thickness $0.30 \mathrm{~mm}$.

The types are from the Miocene of the Vienna Basin, at Nussdorf, where it is noted as rare. Our figured specimen is a topotype. It is in our collection also from Vöslau and Heiligenstadt, in the Vienna Basin, and from Holuluca, in Silesia. Chapman records it from the Miocene of Australia, but his figure shows a very different form, very umbonate. Terquem records it from the Eocene of Vaudancourt, in the Paris Basin, but his figure seems to have been copied from D'Orbigny. I have failed to find it in the material I have had from Vaudancourt.

The two forms figured by D'Orbigny seem to be variations of one species, so far as his figures and our material show.

Elphidium josephinum (D'Orbigny) Bogdanowicz and Fedorov

Plate 11, figure 15

Polystomella josephina D'Orbigny, Foraminifères fossiles du bassin tertiaire de Vienne, p. 130, pl. 6, figs. 25, 26, 1846.

Egger, Neues Jahrb., 1857, p. 303, pl. 15, figs. 10, 11.

Fornasini, Accad. sci. Ist. Bologna Mem., ser. 5, vol. 7, p. $13(649), 1899$.

Ephidium josephina Bogdanowicz and Fedorov, On some representatives of the genus Elphidium of the Sarmatian deposits of the lower Kuban River course, pp. 17, 49, pl. 1, figs. 8-10, text figs. 21, 22, 1932.

Test much compressed, sides flattened, periphery acute, strongly serrate; chambers distinct, somewhat inflated, each with a projecting peripheral angle and short spine, increasing only slightly in size as added; sutures distinct, depressed, slightly curved, retral processes very distinct, extending across the depressed area above the sutures, about 8 in the adult chambers; wall of the chambers smooth except for the retral processes; aperture consisting of several rather widely spaced small openings at the base of the apertural face. Diameter $0.65 \mathrm{~mm}$; thickness $0.20 \mathrm{~mm}$.

The types of the species came from the Miocene of the Vienna Basin at Baden. The specimen here figured is a topotype. It occurs in our collection also from the Miocene of Pätzleinsdorf, Austria, and Acsa, Hungary. Egger records it from the Miocene of Mairhof in Bavaria, and Fornasini records it as very rare at Pozzuoli and in Calabria, Italy.

I have found no specimens with as elongate spines as are shown in D'Orbigny's figure. 
Elphidium aculeatum (D'Orbigny) Bogdanowicz and Fedorov Plate 11, figure 16

Polystomella aculeata D'Orbigny, Foraminifères fossiles du bassin tertiaire de Vienne, p. 131, pl. 6, figs. 27, 28, 1846.

Egger, Neues Jahrb., 1857, p. 303, pl. 15, figs. 3, 4.

Seguenza, Accad. gioenia sci. nat. Atti, ser. 2, vol. 18, p. 17, 1862.

Karrer, Akad. Wiss. Wien Sitzungsber., vol. 58, pt. 1, p. 192 1868.

Terquem, Soc. géol. France Mém., sér. 3, vol. 1, p. 15, 1878

Malagoli, Soc. nat. Modena Atti, ser. 3, vol. 8, p. 183, 1889

Fornasini, Accad. sci. Ist. Bologna Mem., ser. 5, vol. 7, p. 6 (642), 1899.

Schubert, Deutschennaturwiss.-med. Ver. Böhmen "Lotos" Sitzungsber., p. 99, 1900.

Toula, K.-k. geol. Reichsanstalt Jahrb., vol. 64, p. 640, 1914 [1915].

Martinotti, Soc. italiana sci. nat. Atti, vol. 59, p. 334, 1920. Elphidium aculeatum Bogdanowicz and Fedorov, On some representatives of the genus Elphidium of the Sarmatian deposits of the lower Kuban River course, pp. 14, 48, pl. 1 , figs. 4-7, text figs. 13-20, 1932.

Test strongly compressed, umbilical region slightly umbonate, periphery sharply keeled, with small spines, usually one to a chamber but somewhat irregularly scattered; chambers distinct, numerous, 15 to 20 in the final coil of rather uniform shape, increasing very slightly in size as added; sutures distinct, very slightly depressed, gently curved, retral processes numerous, 12 to 15 in the adult chamber, extending about halfway across the chamber; aperture a low opening at the base of the narrow apertural face, usually subdivided into numerous small openings. Diameter $0.85-1.00 \mathrm{~mm}$; thickness $0.20 \mathrm{~mm}$.

D'Orbigny records the species from the Miocene of Baden, near Vienna, Austria, as rare. The specimen here figured is a topotype. The species is recorded from the Miocene of central Europe, Mairhof, Bavaria, Germany (Egger); Kostej, Banat region of Hungary (Karrer); Hungary (Toula); lower Kuban River, Russia (Bogdanowicz and Fedorov); from the Pliocene of southern Europe, Isle of Rhodes (Terquem); Moden, Monte Mario, and Pozzuoli, Italy (Malagoli, Fornasini); and from the Pleistocene of Catania, Sicily (Seguenza, Fornasini).

In our own collections it is represented from the Miocene of Baden, Vöslau, Gaudenzdorf, Kostej, and Holuluca, Austria; Loretto, Italy; and Ortenburg, Germany; and from the Pliocene of Castel Arquato, Calabria, and Zankleano Gravitelli, near Messina, Italy, and Garrobo, Spain.

Our series of specimens show that D'Orbigny's type figure is much conventionalized.

\section{Elphidium reginum (D'Orbigny) Cushman}

Plate 11, figure 19

Polystomella regina D'Orbigny, Foraminifères fossiles du bassin tertiaire de Vienne, p. 129, pl. 6, figs. 23, 24, 1846.

Test compressed, biumbonate, periphery subacute, with 4 to 6 long acicular spines, independent of the chambers, in length equal to the radius of the test; chambers distinct, numerous, usually 18 to 20 in the adult coil, increasing gradually in size as added; sutures distinct, very slightly if at all curved, nearly radiate, retral processes distinct, 10 to 12 in the adult chamber; wall distinctly perforate; aperture with several small openings at the base of the apertural face. Diameter exclusive of spines $1.15-1.25 \mathrm{~mm}$; thickness $0.40 \mathrm{~mm}$.

The types of this beautiful species came from the Miocene of Baden, in the Vienna Basin. There are typical specimens in our collections from Baden, Nussdorf, Vöslau, and Ottakring, all near Vienna. It is strange that this distinctive species should not have been recorded since D'Orbigny's original record. D'Orbigny's figure of this, like those of the other species of the Vienna Basin paper, is much conventionalized.

\section{Elphidium reginum (D'Orbigny) var. caucasicum Bogdanowicz}

\section{Plate 11, figure 17}

Elphidium regina (D'Orbigny) var. caucasicum Bogdanowicz, in Bogdanowicz and Fedorov, On some representatives of the genus Elphidium of the Sarmatian deposits of the lower Kuban River course, pp. 18, 49, pl. 1, figs. 11-14, text figs. 23-26, 1932.

Test convex; spines thick, rounded at the ends, usually in number of 4 , more rarely 3 or 5 ; their surface is longitudinally costate; keel thick, more or less rounded, rather often very indistinct. Umbilical region usually slightly convex; the surface of the test covered with small glassy outgrowths; apertural wall with convex edges; outer part of the convolution made up of 14 to 22 chambers; septal bridges are 11 to 16 in number. Chambers narrow and curved; septal bridges occupying almost all their breadth. Diameter 0.65-1.5 mm; thickness 0.25-0.60 mm.

The types of this variety came from the Miocene of the lower Kuban River, Russia.

A copy of the type figure is given on plate 11.

\section{Elphidium ungeri (Reuss) Cushman}

Plate 11, figure 20

Polystomella ungeri Reuss, Akad. Wiss. Wien Denkschr., vol. 1, p. 369, pl. 48, fig. 2, 1850; Deutsche geol. Gesell. Zeitschr., vol. 3, p. 156, 1851.

Liebus, K.-k. geol. Reichsanstalt Jahrb., vol. 52, p. 100,1903.

Test compressed, elliptical in peripheral view, umbilical region flattened or slightly depressed, periphery subacute, slightly keeled; chambers distinct, somewhat inflated, about 12 in the adult coil, of rather uniform shape, increasing very slightly in size as added; sutures distinct, depressed, somewhat curved, retral processes about 10 in the adult chamber, extending across the sutural depression; wall smootb except for the sutures; aperture consisting of several small openings at the base of the broadly triangular apertural face. Diameter $0.45 \mathrm{~mm}$; thickness $0.25 \mathrm{~mm}$.

The types came from the Miocene of Austria. Reuss records it from the Bernstein-führender sand of Lemberg and from the Leithakalk of Wurzing, St. Nikolai, and Enzersdorf. Liebus records it from the upper Oligocene of upper Bavaria. 
The specimen here figured came from Niederlies, Austria. There are somewhat similar specimens in our collections from the Miocene of San Miniato, near Florence, Italy.

This species in some respects resembles $E$. antoninum (D'Orbigny).

\section{Elphidium subumbilicatum (Czjzek) Cushman}

Plate 11, figure 18

Polystomella subumbilicata Czjzek, Haidinger's Naturwiss. Abh. 2, p. 143, pl. 12, figs. 32, 33, 1848.

Karrer, Akad. Wiss. Wien Sitzungsber., vol. 58, pt. 1, p. 192, 1868; in Von Drasche, Fragmente zu einer Geologie der Insel Luzon, p. 99, 1878.

Fornasini, Accad. sci. Ist. Bologna Mem., ser. 5, vol. 7, p. 19 (655), 1899.

I have had no material to refer to this species. The type figure is copied on plate 11. Czjzek described it from the Miocene of the Vienna Basin. It is also recorded from the Miocene of Kostej, Banat region of Hungary (Karrer); the Tertiary of Luzon, Philippines (Karrer); the Miocene and Pliocene of Calabria, and the Pliocene of Siena, Italy (Fornasini).

Elphidium subumbilicatum (Czjzek) var. centronondepressum (Beutler) Cushman

\section{Plate 11, figure 21}

Polystomella subumbilicata Czjzek var. centronondepressa Beutler, Neues Jahrb., 1909, pt. 2, p. 158, pl. 18, fig. 19.

This variety evidently differs from the typical form in not having the umbilical region depressed. A copy of the figure is here given from the Miocene Globigerina marl of Bahna, Rumanian Carpathians.

\section{Elphidium cryptostomum (Egger) Cushman}

Plate 11, figure 22

Polystomella cryptostoma Egger, Neues Jahrb., 1857, p. 301, pl. 9, figs. 19, 20.

Steuer, Ver. geol. Landesanstalt Darmstadt Notiz., ser. 4, vol. 25, p. 26, pl. 8, figs. 7-9, 1904 [1905].

Test compressed, sides in peripheral view nearly parallel, central portion with a distinct flattened umbo, periphery rounded to subacute, slightly keeled in earlier stages, more rounded in adult; chambers distinct, about 12 in the adult coil, increasing rather rapidly in size in the later portion, slightly inflated; sutures depressed, strongly curved, in some specimens somewhat sigmoid; wall smooth; aperture a low opening at the base of the apertural face, usually partially subdivided. Diameter $0.40-0.70 \mathrm{~mm}$; thickness 0.15 $0.25 \mathrm{~mm}$.

This species was described by Egger from the Miocene of Ortenburg, Bavaria, Germany. Steuer records it from a boring of Oligocene age at Heppenheim, Germany. There are numerous topotypes from Ortenburg in our collection, one of which is here figured.
Elphidium ortenburgense (Egger) Cushman

Plate 12, figure 1

Polystomella ortenburgensis Egger, Neues Jahrb., 1857, p. 302. pl. 15, figs. 7-9.

Test strongly compressed, sides in peripheral view straight, nearly parallel, depressed at the umbilici, periphery acute, slightly keeled; chambers distinct, slightly inflated, numerous, about 15 in the adult coil, increasing gradually in size in the adult: sutures distinct, slightly depressed, strongly curved, retral processes numerous, as many as 15 in the adult chamber, occupying about half the width of the chamber; wall smooth except for the retral processes and the umbilical regions, which are papillate; aperture consisting of numerous small rounded openings at the base of the triangular apertural face. Diameter $0.50 \mathrm{~mm}$; thickness $0.20 \mathrm{~mm}$.

The types came from the Miocene of Ortenburg, Germany. The figure on plate 12 shows a topotype. The species resembles $E$. ungeri Reuss, but the chambers are less inflated, the sides more nearly parallel, and the depressed umbilical regions papillate.

\section{Elphidium subcarinatum (Egger) Cushman}

Plate 12, figure 2

Polystomella subcarinata Egger, Neues Jahrb., 1857, p. 301, pl. 14, figs. 24, 25.

On plate 12 is a copy of the type figure. The specimens were collected from the Miocene of Hausbach, Bavaria, Germany. There seem to be no other records, and I have failed to find the species in any of my material. In side view this species is much like $E$. angulatum (Egger), from the same locality, but the peripheral views are very different.

\section{Elphidium angulatum (Egger) Cushman}

Plate 12, figure 3

Polystomella angulata Egger, Neues Jahrb., 1857, p. 302, pl. 15, figs. 5,6 .

The types of this species came from the Miocene of Hausbach, Bavaria, Germany. I have been unable to find any specimens that seem identical with this. The type figures are copied on plate 12 .

Elphidium nobile (Karrer) Cushman

Plate 12, figure 4

Polystomella nobilis Karrer, Akad. Wiss. Wien Sitzungsber., vol. 50, pt. 1, p. 710 , pl. 2, fig. 15, 1864 [1865].

Our figure shows a topotype specimen of this species from the Miocene Leythakalk of Mölding, near Vienna, Austria. It is distinctly eroded. The type figure also leaves much to be desired as to the complete details. There are evidently many chambers and a distinct umbo, the periphery lobulate and acute. 


\section{EIphidium falunicum (Allix) Cushman}

Plate 12, figures 5, 6

Polystomella falunica Allix, Feuille des jeunes naturalistes, vol. 43, p. 45 , text fig. $9,1913$.

Test somewhat compressed, elliptical in peripheral view, periphery rounded, umbilical region with a flattened or slightly depressed area; chambers distinct, little if at all inflated, 10 to 12 in the adult coil, of uniform shape, increasing very slightly in size in the adult coil; sutures distinct, very slightly depressed, gently curved, retral processes very short, about 10 in the adult chamber; wall smooth and polished; aperture a low opening at the base of the apertural face. Diameter 0.50-0.55 mm; thickness $0.25 \mathrm{~mm}$.

The types came from the Miocene of southern France. I have material from the Miocene, Helvetien, Pontlevoy Touraine; and Salles, Moulin du Minoy; Burdigalien inférieur, Moulin de l'Église, Saucats, Gironde; Le Coquillat, Léognan; Aquitanien supérieur, La Bréde, Larriey; and St. Arit, near Mont de Marsan, France.

It is a very distinct species in this region.

Elphidium inflatum (Reuss) Cushman

Plate 12, figure 7

Polystomella inflata Reuss, Akad. Wiss. Wien Sitzungsber., vol. 42, p. 358, pl. 1, fig. 10a, b, 1860 [1861]; Acad. royale sci. Belgique Bull., ser. 2, vol. 15, p. 157, 1863.

Hosius, Naturh. Ver. preuss. Rheinlande u. Westfalens Verh., vol. 50, p. 129, pl. 2, figs. 15, 16, 1893.

Clodius, Ver. Freunde Naturges. Mecklenburg Archiv 75. Jahr., p. 145, 1922

Test little compressed, very slightly so in the later portion, periphery very broadly rounded, entire, in the early part of the adult coil with a slight keel, later becoming obsolescent, umbilici slightly depressed; chambers fairly distinct, not inflated, comparatively few, about 10 in the final coil, of rather uniform size and shape; sutures slightly if at all depressed, marked only by the retral processes, which are numerous, about 15 in the adult chamber, flush with the surface and marked largely by the slitlike openings; wall otherwise smooth; aperture consisting of numerous small, rounded openings at the base of the broadly arched apertural face. Diameter $0.45-0.55 \mathrm{~mm}$; thickness $0.40 \mathrm{~mm}$.

The types of this species came from the Miocene of Dingden, near Bocholt, Westphalia, Germany. Our figured specimen is a topotype. The species is very common at this locality. It is recorded from Mecklenburg, Germany, by Clodius. Reuss also records this species from the Pliocene Crag of Antwerp, Belgium, but I have found no specimens in the Antwerp material I have examined.
Elphidium strattoni (Applin, Ellisor, and Kniker) Cushman

Plate 12, figures 8,9

Polystomella strattoni Applin, Ellisor, and Kniker, Am. Assoc. Petroleum Geologists Bull., vol. 9, no. 1, p. 100, pl. 3, figs. 9, 10, 1925.

Test equally biconvex, about twelve to fourteen chambers in the last-formed coil, periphery narrowly rounded but not keeled, slightly lobulated, umbilical region flattened to slightly depressed. filled with clear shell material. Septal lines slightly depressed, evenly and narrowly bridged by small retral processes. Aperture a narrow slit at the base of the apertural face of the chamber.

The types came from the upper Miocene, from well samples taken at Stratton Ridge, Brazoria County, Tex. It is reported as one of the most common species of the marine Miocene of Texas.

\section{Elphidium tricostatum (Protescu) Cushman}

Plate 12, figure 10

Polystomella tricostata Protescu, Inst. geol. Romaniei Anuar., vol. 9, 1915-20, p. 348, pl. 4, figs. 4, 5, 1922.

The original figures of this species are so dark that much of the detail is lost. They have been photographed and appear on plate 12 to show some of the details. The chambers are numerous, low, and have the retral processes raised into a more or less continuous reticulation covering the entire test.

The types are from the Tertiary of Rumania.

Elphidium macellum (Fichtel and Moll) var. tumidocamerale Bogdanowicz

Plate 12, figure 11

Elphidium macellum (Fichtel and Moll) var. tumidocamerale Bogdanowicz, in Bogdanowicz and Fedorov, On some representatives of the genus Elphidium of the Sarmatian deposits of the lower Kuban River course, pp. 11, 48, pl. 1, fig. 2, text figs. 9, 10, 1932.

In the adult the test is more convex and has some broad, inflated chambers at the end of the convolution; septal bridges of the chambers occupy only the first one third part of their surface. Chambers of the remainder of the test can't be distinguished from those of the $E$. macellum. Keeled margin is more or less often supplied with several minute spines.

Keel is very slightly expressed in the inflated chambers at the end of the convolution. Septal bridges are 12 in number.

Diam. $0.5 \mathrm{~mm}$; thickness $0.15 \mathrm{~mm}$.; thickness of the last chamber $0.25 \mathrm{~mm}$. Scarce.

The above is an exact copy of the descriptive notes given by Bogdanowicz. A copy of his figure is given on plate 12. The specimen came from the Miocene Sarmatian of the lower Kuban River, Russia.

\section{Elphidium chipolense (Cushman) Cushman}

Plate 12, figure 12

Polystomella chipolensis Cushman, U. S. Geol. Survey Prof Paper 128-B, p. 72, pl. 11, fig. 23, 1921.

Elphidium chipolensis Cushman and Ponton, Florida Geol. Survey Bull. 9, p. 70, pl. 11, figs. 3a, b, 1932. 
Test with the periphery rounded, composed of 10 to 12 chambers in the last-formed coil; chambers fairly distinct, but not inflated; sutures more or less indistinct, owing to the surface costae, which occupy the whole area between the sutures, and in the earlier portions becoming fused and nearly continuous. Diameter 1.25 $\mathrm{mm}$.

This species has been recorded from the Miocene of Florida at many stations in the Chipola, Oak Grove, Shoal River, and Hawthorne formations.

The early portion has very long retral processes.

\section{Elphidium fimbriatulum (Cushman) Cushman}

Plate 12, figure 13

Polystomella fimbriatula Cushman, U. S. Geol. Survey Bull. 676 , p. 20, pl. 8, fig. 5, 1918.

Elphidium fimbriatulum Cole, Florida Geol. Survey Bull. 6, p. 33, pl. 4, fig. 7, 1932.

Cushman and Ponton, Florida Geol. Survey Bull. 9, p. 70, pl. 11, figs. 2a, b, 1932.

Test much compressed, periphery acute, slightly keeled, biumbonate; chambers distinct, central portion of each raised into a high ridge, of rather uniform shape, increasing regularly in size as added; sutures indistinct, marked by the retral processes, which are narrow but extend across the depressed area, about 10 in the adult chamber; wall with definite raised ridges and intermediate depressions; aperture a low opening at the base of the apertural face, sometimes subdivided. Diameter $0.75-0.85 \mathrm{~mm}$; thickness $0.22-0.25 \mathrm{~mm}$.

This species was originally described from the Pliocene Caloosahatchee marl on the Caloosahatchee River, Fla., and Waccamaw formation on the Waccamaw River, S. C. It also occurs in the upper portion of the Miocene Choctawhatchee formation in the bed of the Econfina River, sec. 28, T. 2 N., R. 12 W., Bay County, Fla. The central portions of the chambers are raised and give the appearance rather of raised sutures.

\section{Elphidium subsphaericum Cushman and Hedberg}

\section{Plate 12, figures 14, 15}

Elphidium subsphaericum Cushman and Hedberg, Cushman Lab. Foram. Research Contr., vol. 6, p. 64, pl. 9, figs. 1, 2, 1930.

Test subspherical, the periphery very broadly rounded and the axis of coiling often broader than the height of the test; chambers distinct, slightly inflated, typically 8 or 9 ; sutures slightly depressed, marked by the retral processes, which number 12 to 16 ; wall smooth, coarsely perforate; aperture represented by numerous circular openings at the base of the apertural face of the lastformed chamber. Height $0.30-0.40 \mathrm{~mm}$; diameter $0.30-0.40 \mathrm{~mm}$.

The types came from the middle Miocene Urumaco formation of the District of Democracia, State of Falcón, Venezuela.

$1819-39-4$
This is a very thick, rounded species with its nearest relative typical Elphidium striato-punctatum of the Red Sea, but it differs from that species in the much smaller size, much fewer chambers, and greater inflation of the chambers. This species apparently has a rather limited stratigraphic range in the Urumaco formation (middle Miocene) of northern Falcón. The specimens described were obtained from well samples, which to the extent of present knowledge show the occurrences of this species to be limited to a zone only a few hundred feet thick. Other species of Elphidium are fairly common throughout the formation, which is several thousand feet thick.

Elphidium glabratum Cushman, n. sp.

Plate 12, figure 16

Test compressed, narrowly elliptical in peripheral view, slightly umbonate, periphery rounded; chambers distinct, numerous, 20 or more in the adult coil, of rather uniform shape, increasing very gradually in size as added, not inflated; sutures distinct, slightly depressed, distinctly curved, or slightly sigmoid, retral processes covering about two-thirds of the width of the chamber, about 12 in the adult chamber; wall, except for the depressions along the sutures, smooth, polished; aperture a low opening at the base of the apertural face. Diameter $0.65-0.75 \mathrm{~mm}$; thickness $0.30 \mathrm{~mm}$.

Holotype (Cushman coll., no. 22690) from the Miocene Aquitanien supérieur of St. Arit, near Mont de Marsan, France.

This species differs from $E$. falunica (Allix) in the greater number of chambers and much longer retral processes.

\section{Elphidium chapmani Cushman}

Plate 12, figure 17

Elphidium chapmani Cushman, Cushman Lab. Foram. Research Contr., vol. 12, p. 80, pl. 14, figs. 6a, b, 1936.

Test distinctly rhomboid in peripheral view, strongly umbonate, periphery acute but not keeled; chambers distinct, very numerous, 25 to 30 in the adult coil, of about uniform height throughout, low and curved, very slightly inflated; sutures distinct, slightly depressed, curved, retral processes numerous, 20 or more in the adult chamber, short; wall smooth and polished, the umbo with numerous irregular pits; aperture consisting of numerous small pores at the base of the sharply triangular apertural face. Diameter $1.25 \mathrm{~mm}$; thickness $0.65-0.70 \mathrm{~mm}$.

The types came from the Miocene of Neumerella, Victoria, Australia.

\section{Elphidium parri Cushman}

Plate 12, figure 18

Elphidium parri Cushman, Cushman Lab. Foram. Research Contr., vol. 12, p. 81, pl. 14, figs. 7a, b, 1936.

Test somewhat compressed, slightly umbonate, the faces nearly parallel in the middle, thence sharply 
sloping to the subacute periphery; chambers distinct, numerous, 20 to 25 in the adult coil, slightly inflated, of nearly uniform height throughout; sutures depressed, very slightly curved, retral processes about half the width of the chamber, 7 or 8 in the adult chamber; wall smooth except over the sutures, umbo with numerous rounded pits; aperture consisting of a series of small, obscure, rounded openings at the base of the narrow, chevron-shaped apertural face. Diameter $0.70-0.80$ $\mathrm{mm}$; thickness $0.35-0.40 \mathrm{~mm}$.

The types came from the Miocene of Neumerella, Victoria, Australia.

\section{Elphidium subinflatum Cushman \\ Plate 12, figure 20}

Elphidium subinflatum Cushman, Cushman Lab. Foram. Research Contr., vol. 12, p. 84, pl. 15, figs. 1a, b, 1936.

Test somewhat compressed, biumbilicate, periphery subacute, slightly keeled; chambers fairly distinct, comparatively few, increasing rather rapidly in size as added, little if at all inflated; sutures distinct, strongly curved, retral processes very elongate, extending clear across the earlier chambers, 12 or more in the adult chamber; wall coarsely reticulate; aperture composed of several small openings at the base of the somewhat heart-shaped apertural face. Diameter $0.60 \mathrm{~mm}$; thickness $0.35 \mathrm{~mm}$.

The types came from the Miocene Filter Quarries, Batesford, Victoria, Australia.

\section{Elphidium semistriatum (D'Orbigny) Cushman}

Plate 12, figure 21

Polystomella semistriata D'Orbigny, Annales sci. nat., vol. 7, p. 284, no. 7, 1826.

Fornasini, Accad. sci. Ist. Bologna, Mem., ser. 5, vol. 7, p. 17 (653), text fig. 4, 1899.

Test much compressed, biumbilicate, periphery broadly rounded, sides concave toward the middle; chambers distinct, slightly inflated, 9 or 10 in the adult coil, of uniform shape, increasing very slightly in size as added; sutures distinct, slightly depressed, earlier ones strongly curved, later ones progressively less so, retral processes very short, about 12 in the adult chamber; wall smooth, distinctly perforate; aperture consisting of a series of small rounded openings at the base of the apertural chambers. Diameter $0.60 \mathrm{~mm}$; thickness $0.22 \mathrm{~mm}$.

The types of this species came from the Pliocene of Castel Arquato, Italy. The specimen here figured is a topotype.

\section{Elphidium decipiens (Costa) Cushman}

Plate 12, figures 19, 22

Polystomella decipiens Costa, Accad. pontaniana Atti, vol. 7, fasc. 2 , p. 220, pl. 19, figs. 13a, b, 1856 .

There are several interpretations of the characters of this species, to judge from the figures given by later authors and referred to decipiens. The original figures given by Costa are reproduced on plate 12. There is evidently a distinct, beaded boss in the umbilical region, a somewhat lobulate periphery, and a longitudinally costate surface. The figures given by Fornasini are somewhat similar but lack the striate character and the rhomboidal peripheral view. Heron-Allen and Earland, ${ }^{17}$ give figures that are referred here, but they show a form distinctly biumbilicate and with a very different peripheral view.

On plate 12 is figured a specimen that agrees in many respects with the figures and description given by Costa. It is from the Pliocene of Monte Mario, near Rome, Italy.

\section{Elphidium salentinum (Costa) Cushman}

Plate 13, figure 1

Polystomella salentina Costa, Accad. pontaniana Atti, vol. 7, fasc. 2, p. 218, pl. 19, figs. 12A, B, C, 1856.

Fornasini, Accad. sci. Ist. Bologna Mem., ser. 5, vol. 7, p. 17 (653), 1899.

Like other figures given by Costa this has a very much conventionalized appearance. Copies of the original figures are given on our plate. The specimens are from the Pliocene of Italy. It is possibly a synonym of E. macellum (Fichtel and Moll).

\section{Elphidium exoletum (Costa) Cushman}

Plate 13, figure 2

Polystomella exoleta Costa, Accad. pontaniana Atti, vol. 7, fasc. 2, pl. 19, fig. 10, 1856.

Fornasini, Accad. sci. Ist. Bologna Mem., ser. 5, vol. 7, p. 11 (647), 1899.

The type figures are copied on plate 13. They are evidently somewhat conventionalized, and I have been unable to find any specimens in the Italian Tertiary that fit this.

\section{Elphidium spinulosum (Costa) Cushman}

Plate 13, figure 3

Polystomella spinulosa Costa, Accad. pontaniana Atti, vol. 7, fasc. 2 , pl. 19, fig. 14, 1856.

Fornasini, Accad. sci. Ist. Bologna Mem., ser. 5, vol. 7, p. 18 (654), 1899.

The original figure given by Costa and copied on plate 13 is very evidently much conventionalized. It may possibly belong to $E$. crispum (Linné). It is from the Pliocene of Italy.

\section{Elphidium teretiusculum (Terquem) Cushman}

\section{Plate 13, figure 4}

Polystomella teretiuscula Terquem, Soc. géol. France Mém., sér. 3 , vol. 1, p. 16, pl. 1 (6), figs. 9, 10, 1878.

The original figures are copied on plate 13 . I have not found this form in the material examined from the Isle of Rhodes, from which Terquem described the species.

17 Heron-Allen, Edward, and Earland, Arthur, The Foraminifera of the West of Scotland: Linnean Soc. London Trans., ser. 2, vol. 11, p. 282, pl. 43, figs. 20-22, 1916. 
Elphidium punctatum (Terquem) Cushman

Plate 13, figure 5

Polystomella punctatum Terquem, Soc. géol. France Mém., sér. 3, vol. 1, p. 16, pl. 1 (6), figs. 7a, b, 1878.

Copies of Terquem's type figures from the Pliocene of the Isle of Rhodes are given on plate 13. I have been unable to find any specimens resembling this in the Pliocene material I have examined from that locality.

\section{Elphidium laminatum (Terquem) Cushman}

Plate 13, figure 6

Polystomella laminata Terquem, Soc. géol. France Mém., sér. 3, vol. 1, p. 16, pl. 1 (6), figs. 8a, b, 1878.

According to the type figures, which are reproduced on plate 13 , this species is very strongly compressed and depressed at the umbilici, strongly keeled, and with a complete reticulation due to the elongate retral processes. The types came from the Pliocene of the Isle of Rhodes.

It may be noted that Terquem later ${ }^{18}$ recorded the species from the Eocene of Vaudancourt, in the Paris Basin, but the figures show the two to be different. I failed to find any such form in the material I have had from Vaudancourt or from the Isle of Rhodes.

\section{Elphidium hughesi Cushman and Grant}

\section{Plate 13, figure 7}

Elphidium hughesi Cushman and Grant, San Diego Soc. Nat. History Trans., vol. 5, no. 6, p. 75, pl. 7, fig. 1, 1927.

Cushman, Stewart, and Stewart, San Diego Soc. Nat. History Trans., vol. 6, p. 61, pl. 3, fig. 15, 1930.

Test rather small, periphery broadly rounded throughout, increasingly so in the last chambers, the diameter about two and one-half times the thickness; umbilical region slightly depressed, typically with a series of irregular flattened areas formed by the cut-off ends of the pointed inner ends of the chambers with depressions between; chambers as many as 14 in the last-formed coil, usually less than 12, the last few inflated and the periphery lobulate, earlier ones not inflated and the periphery entire; sutures very distinct, the later ones strongly depressed, slightly curving toward the periphery, retral processes few and short; wall fairly thick, very finely perforate; aperture a series of small rounded openings at the base of the apertural face, none in the face itself. Diameter $0.60-0.70 \mathrm{~mm}$; thickness $0.25-$ $0.30 \mathrm{~mm}$.

The types of this species came from the $\mathrm{N} \frac{1}{2}$ sec. 12 , T. 21 S., R. 10 E., Mount Diablo base and meridian, Pine Valley, Monterey County, Calif., from R. D. Reed's Poncho Rico formation, of lower Pliocene or possibly upper Miocene age. The species also occurs in the Pliocene of Humboldt County, Calif.

18 Terquem, Olry, Les foraminifères de l'Eocène des environs de Paris: Soc: gêol. France Mém., sér. 3, vol. 2, p. 47, pl. 2 (10), figs, 24a, b, 1882.
This species has probably been referred to in the literature as Polystomella striato-punctata, but without checking original material it is difficult to determine this.

Elphidium hughesi Cushman and Grant var. foraminosum Cushman, n. var.

Plate 13, figure 8

Elphidium hughesi Cushman and Grant var., San Diego Soc. Nat. History Trans., vol. 15, no. 6, p. 76, pl. 7, figs. 5a, b, 1927.

Variety differing from the typical form in having the last-formed chambers less inflated, test thinner, perforations more conspicuous, and umbilici with a few large irregular bosses.

Holotype (California Academy of Science coll.) from the Pliocene Etchegoin formation of the San Joaquin Valley, Calif. Similar forms occur in the Pliocene Fernando group of Schumanns Cut on the Southern Pacific Railroad, 21/2 miles northeast of Casmalia, Casmalia Hills, Santa Barbara County, Calif., and in the Pliocene Merced formation at Sevenmile Beach, 1 1/4 miles north of Mussel Rock, San Mateo County, Calif.

\section{Elphidium hughesi Cushman and Grant var. obesum Cush-} man, n. var.

Plate 13, figure 9

Elphidium hughesi Cushman and Grant var., San Diego Soc Nat. History Trans., vol. 5, no. 6, p. 75, pl. 7, figs. 4a, b, 1927.

Variety differing from the typical form in being smaller and thicker, with a more rounded periphery and the wall thin and conspicuously perforate.

Holotype (California Academy of Science Coll.) from the Pliocene Purisima formation on Purisima Creek, San Mateo County, Calif.

\section{Elphidium gunteri Cole}

Plate 13, figure 10

Elphidium gunteri Cole, Florida Geol. Survey Bull. 6, p. 34, pl. 4, figs. 9, 10, 1931.

Hadley, Elisha Mitchell Sci. Soc. Jour., vol. 52, no. 1, p. $35,1936$.

Elphidium craticulata (Fichtel and Moll) var. Cushman, U. S. Geol. Survey Bull. 676, p. 20, 1918.

Test of medium size for the genus, margin entire, broadly rounded, sides slightly convex in peripheral view, umbilical region with a group of irregular, slightly raised areas of clear shell material; chambers distinct, not inflated, averaging about 14 in the last volution; sutures not depressed, marked by slightly raised, rectangular-shaped retral processes, which at the base of the chambers tend to fuse together; wall smooth, shiny, distinctly and rather coarsely perforate; aperture composed of several rounded openings at the base of the apertural face. Diameter $0.44 \mathrm{~mm}$; thickness $0.26 \mathrm{~mm}$.

The types came from the Pliocene Caloosahatchee marl in the Orange City marl pit, Orange County, Fla. It also occurs in the same formation in the city marl 
pit, just south of De Land and at Deleon Springs, Volusia County, Fla., and in the Waccamaw formation on the Cape Fear River at Neil Eddy Landing, 28 miles above Wilmington, N. C. Hadley records it as a living form off Beaufort, N. C.

\section{Elphidium ibericum (Schrodt) Cushman}

Plate 13, figure 11

Polystomella iberica Schrodt, Deutsche geol. Gesell. Zeitschr., vol. 42, p. 417, pl. 22, fig. 9, 1890.

The type figure shows a test with large umbones, with scattered depressions, the chambers very numerous and low. The figure is very evidently much conventionalized. The types came from the Pliocene of southern Spain. The specimen shown on plate 13 came from the Pliocene of Monte Mario, near Rome, Italy, and in its characters seems to be identical with that of Schrodt.

\section{Elphidium pseudonodosum Cushman}

Plate 13, figure 12

Elphidium pseudonodosum Cushman, Cushman Lab. Foram. Research Contr., vol. 12, p. 82, pl. 14, figs. 9a, b, 1936.

Test compressed, slightly if at all umbonate, middle part of sides nearly parallel in peripheral view, thence rapidly narrowing to the periphery, which has a broad, rounded keel; chambers distinct, the anterior portion raised, depressed toward the suture, numerous, about 20 in the adult coil, of rather uniform shape and height; sutures distinct, strongly curved, retral processes short, about 15 in the adult chamber; wall smooth and polished except for the retral processes and depressions; aperture consisting of numerous rounded parts at the base of the low, chevron-shaped apertural face. Diameter $1.25 \mathrm{~mm}$; thickness $0.50 \mathrm{~mm}$.

The types of this species came from the lower Pliocene at Forsyth's Grange Burn, Hamilton, Victoria, Australia.

\section{Elphidium georgianum Cushman}

Plate 13, figure 13

Elphidium georgianum Cushman, Cushman Lab. Foram. Research Contr., vol. 11, p. 79, pl. 12, figs. 5a, b, 1935; Geol. Soc. America Bull., vol. 47, p. 428, pl. 3, figs. 12a, b, 1936.

Test close-coiled throughout, completely involute, strongly umbonate, periphery subacute, slightly lobulate; chambers fairly distinct, about 12 in the lastformed coil, the later ones very slightly inflated; sutures fairly distinct, covered, particularly toward the periphery, with about 10 retral processes in the adult; walls fairly thick, distinctly perforate; aperture consisting of a series of small pores at the base of the apertural face. Diameter $0.70 \mathrm{~mm}$; thickness $0.30 \mathrm{~mm}$.

The types are from a late Tertiary green clay of Canyon III, Georges Bank. It should be found as a living form in this same region.

\section{Elphidium oregonense Cushman and Grant}

Plate 13, figures 14-16

Elphidium oregonense Cushman and Grant, San Diego Soc. Nat. History Trans., vcl. 5, no. 6, p. 79, pl. 8, fig. 3, 1927.

Cushman, Stewart, and Stewart, San Diego Soc. Nat. History Trans., vol. 6, no. 2, p. 62, pl. 4, figs. 1, 2, 1930.

Test comparatively large, complanate, compressed, periphery rounded, umbilical region strongly umbonate, with a rounded boss of clear shell material with severai large pores; chambers numerous, 20 or more in the adult, slightly inflated; sutures curved, depressed except toward the periphery, where they are indistinct, pores numerous, rounded except toward the periphery, where they become elongate; wall thick; aperture consisting of a low, broad opening at the base of the apertural face with circular pores on the middle portion of the lower half of the flattened wall of the apertural face. Length up to $1.8 \mathrm{~mm}$; breadth $0.60 \mathrm{~mm}$.

The types of this species came from the Pleistocene upper portion of a sea cliff near the mouth of the Elk River, 3 miles southeast of Cape Blanco, Curry County, Oreg. It also occurs in the Pliocene of Humboldt County, Calif.

This is a very large, well-characterized species.

\section{Elphidium crispum (Linné) Cushman and Grant}

Plate 13, figures 17-21

"Cornu Hammonis orbiculatum" Plancus (Bianchi), Conchyliologia mineralogica, p. 10, pl. 1, fig. 2, 1739.

"Nautilus minimus" Gualteri, Index Testaceorum Conchyliologiae, pl. 19, figs. A, D, 1742.

Nautilus crispus Linné, Systema naturae, ed. 10, p. 709, 1758; ed. 13 (Gmelin's), p. 3370, 1788.

Fichtel and Moll, Testacea microscopica, p. 40, pl. 4, figs. $\mathrm{d}-\mathrm{f}, 1798$.

Polystomella crispa Lamarck, Histoire des animaux sans vertèbres, vol. 7, p. 625, 1822 .

D'Orbigny, Annales sci. nat., vol. 7, p. 283, no. 1; Modèles, no. 45,1826 ; Foraminifères fossiles du bassin tertiaire de Vienne, p. 125, pl. 6, figs. 9-14, 1846.

Parker, Jones, and H. B. Brady, Annals and Mag. Nat. History, ser. 3, vol. 16, p. 26, pl. 3, fig. 96, 1865.

H. B. Brady, Challenger Rept., Zoology, vol. 9, p. 736, pl. 110, figs. 6, 7, 1884.

Elphidium crispum Cushman and Grant, San Diego Soc. Nat. History Trans., vol. 5, no. 6, p. 73, pl. 7, figs. 3a, b, 1927.

Cushman and Leavitt, Cushman Lab. Foram. Research Contr., vol. 5, pl. 20, p. 4, figs. 3, 4, 1929.

Cushman, U. S. Nat. Mus. Bull. 104, pt. 7, p. 20, 1930.

Cushman and Valentine, Stanford Univ., Dept. Geol., Contr., vol. 1, no. 1, p. 21, pl. 5, figs. 12a, b, 1930.

Dolgopolskaja and Pauli, Sta. Biol. Karadagh Travaux, vol. 4, p. 34, pl. 3, figs. 13a-c, text figs. 1-3, 1931 .

Hada, Tohoku Imp. Univ. Sci. Repts., ser. 4, Biol., vol. VI, p. 123, 1931.

Bogdanowicz and Fedorov, On some representatives of the genus Elphidium of the Sarmatian deposits of the lower Kuban River course, pp. 12, 48, pl. 1, fig. 3, text figs. 11, $12,1932$.

Macfadyen, Geol. Mag., vol. 69, pl. 35, figs. 18a, b, 1932.

Cushman, U. S. Nat. Mus. Bull. 161, pt. 2, p. 47, pl. 11, figs. 4a, b, 1933.

Tolmachoff, Carnegie Mus. Annals, vol. 23, p. 304, pl. 40, figs. 26, 27, 1934. 
Themeon rigatus Montfort, Conchyliologie systématique, vol. 1, p. 203, 51 ${ }^{\circ}$ genre, 1808 .

?Polystomella granulata Costa, Accad. pontaniana Atti, vol. 7, pt. 2, p. 214, pl. 10, figs. 7a, A, B, C, 1856.

Test of large size for the genus, about two and onehalf times longer than wide in peripheral view, lenticular, completely involute, the umbilical regions with a medium-sized, slightly projecting, rounded boss of clear shell material, the surface of which is set with 10 to 12 small, shallow, rounded pits, periphery sharply angular but not sharply keeled, sometimes becoming slightly lobulate and blunter in the last portion of the adult coil; chambers very numerous, 20 to 40 , long, narrow, the last few often inflated, forward part slightly raised, giving a radially ribbed appearance; sutures somewhat sigmoid, the middle portion of each nearly radial, partially obscured by the retral processes, set with pores, those of the earlier ones indistinct but later ones with large and deep pores; wall finely perforate with about 12 relatively long retral processses extending well up onto the side of the next added chamber, appearing as fairly widely spaced, low elevations of the wall in the earlier chambers but as thicker and more rodlike structures in the later chambers; aperture a row of small openings between the retral processes at the base of the apertural face, which is low, sagittate, the sides often slightly concave, the ends pointed. Diameter up to $3 \mathrm{~mm}$; thickness 0.40$1.00 \mathrm{~mm}$.

Linné did not figure this species, but in the thirteenth (Gmelin's) edition he refers among others to Plancus and Gualtieri in the references cited above. Both these authors had most of their material from Rimini, on the Adriatic, and Linné simply says "Mediterranean." One of the specimens figured on plate $13 \mathrm{I}$ collected at Rimini. The figures given by Plancus show an umbonate form but little more except the many, somewhat curved chambers. Gualtieri in his figure A gives a form that is undoubtedly an Elphidium, with a thin keel and distinctly umbonate. Linné in his description says "umbilicata", but the figures mentioned above are distinctly umbonate. Fichtel and Moll's figures are copied on plate 13 and show a distinctly umbonate form, rhomboid in peripheral view and acute. D'Orbigny's model, a photograph of which is given on plate 13 , also has these same characters very clearly. The figure given in the Challenger report, also copied on plate 13 , shows a very similar form. With all these figures the characters of Linné's species seem rather clear. The distribution of this species is difficult to determine exactly, but it apparently is found in the Miocene and Pliocene of south-central and southern Europe, living in the Mediterranean and possibly in the Indo-Pacific. The material from the late Tertiary of the California region and the form now living on the west coast of America, as well as that from Japan, also seem identical.
It is evident from a study of the figures given by various authors under this name that many of them do not belong here, and some of these that are most definite will be found in the synonymy under other species.

There are specimens in our collection referable to this species from the following localities: Miocene, Nussdorf, Steinabrunn, Rausnitz, Imendorf, Holuluca, Niederleis, Loos, Wiener-Neustadt; Perchtoldsdorf, and Kalksburg, Austria; Pecten Bank, near Loretto, Italy; Kostej, Hungary; Point Gourguet and Moulin de l'Église, Saucats, France. Pliocene, Paggiarone and Coroncina, near Siena, Castel Arquato, Calabria, and Monte Mario, near Rome, Italy; Lanarka, Island of Cyprus; and New Corinth, near Kalamaki, Greece. Pleistocene, Santa Barbara, Calif. Recent specimens apparently identical came from Rimini; Lido, Venice; and Bay of Naples, Italy; Tripoli; Red Sea; Karachi, India; Philippines; Japan; Fiji; Caroline Islands; Ladrone Islands; off the west coast of America; Monterey Bay; and off the Channel Islands, Calif.

\section{Elphidium macellum (Fichtel and Moll) Montfort}

Plate 14, figures 1-3; plate 15, figures 9, 10

Nautilus macellus Fichtel and Moll, Testacea microscopica, p. 66, var. $\beta$, pl. 10, figs. $\mathrm{h}-\mathrm{k}, 1798$.

Elphidium macellum Montfort, Conchyliologie systématique, vol. 1, p. 15, 4 $4^{\text {e genre, } 1808 .}$

Cushman and Leavitt, Cushman Lab. Foram. Research Contr., vol. 5, p. 18, pl. 4, figs. 1, 2, 1929.

Test of medium size for the genus, about three and one-half times longer than wide in peripheral view, lenticular, planispiral, completely involute, umbilical regions flat, periphery angular, slightly more rounded in the last-formed chambers, slightly keeled, somewhat lobulate; chambers numerous, averaging 17 in adults in the last-formed coil, slightly arched, giving a ribbed appearance to the test; sutures slightly depressed, those of the last-formed chambers slightly more so, partially obscured by the retral processes, curved backward strongly toward the periphery, the proximal half nearly radial, set with indistinct pores; wall thin, finely perforate, usually with less than 12 relatively long retral processes, more widely spread than in E. crispum and extending from well up on the side of the chamber to the front of the preceding and appearing as narrow, fairly widely spaced, low elevations of the wall; aperture a row of small openings between the retral processes at the base of the apertural face, which is convex, sagittate, with the sides slightly convex, the lobes sharply angled, saddling the preceding coil. Diameter typically less than $1 \mathrm{~mm}$; thickness $0.25 \mathrm{~mm}$.

The types of this species came from the Mediterranean. It is apparently present in the Miocene and Pliocene of south-central and southern Europe, living in the Mediterranean and probably in the Indo-Pacific. It has a very small umbo, which is, however, not 
projecting and does not have the same rhomboid form nor as many chambers as E. crispum.

Material referred to this species is in our collection from the following localities: Miocene, Vöslau, Hölles, Nikolsburg, Kalksburg, Loos, Niederleis, Imendorf, Rausnitz, and Gainfarm, Austria; Varpolata, Hungary; Loretto and San Miniato, near Florence, Italy; Oran, Africa; Shallufa, Wadi Rieina, Wadi El Bir, and Gebel Murr, Egypt; Burdigalien inférieur, Moulin de l'Église, Saucats, Gironde, and St. Paul de Dax, Landes, France; Burdigalien supérieur, Point Gourguet, Saucats, Aquitanien supérieur, La Bréde, Larriey, and St. Arit, near Mont de Marsan, France. Pliocene, Monte Mario, near Rome, Italy. There are Recent specimens from Sebenico, on the Adriatic, from off the island of Delos, Mediterranean, and from beach sand at Karachi, India.

The form figured by Fichtel and Moll as Nautilus strigillatus var. $\alpha^{19}$ is difficult to distinguish from E. macellum (Fichtel and Moll) in Mediterranean material. The original figures show a difference, especially in the umbilical region. Figures $1-3$ on plate 14 show the original of Fichtel and Moll and also European specimens that may be referred to it.

The form from the Pliocene of Italy figured by Costa as Polystomella striolata ${ }^{20}$ without descriptions may belong here.

\section{Elphidium macellum (Fichtel and Moll) var. granulosum}

(Sidebottom) Cushman

Plate 14, figure 4

Polystomella macella (Fichtel and Moll) var. granulosa Sidebottom, Manchester Lit. Philos. Soc. Mem. and Proc., vol. 53, no. 21, p. 16, pl. 5, fig. 5, 1909.

Heron-Allen and Earland, Soc. sci. hist. nat. Corse Bull., p. 141, 1922.

In this variety the whole test is covered with minute granules or tubercles. The types were found off the island of Delos, in the Mediterranean, at Palermo, and off the island of Corsica.

Elphidium macellum (Fichtel and Moll) var. limbatum (Chapman) Cushman

Plate 14, figure 5

Polystomella macella (Fichtel and Moll) var. limbata Chapman, Quekett Micr. Club Jour., ser. 2, vol. 10, p. 142, pl. 10, figs. 9a, b, 1902.

Elphidium macellum (Fichtel and Moll) var. limbatum Cushman, U. S. Nat. Mus. Bull. 161, pt. 2, p. 50, pl. 11, figs. 9a, b, 1933.

This variety has the umbilical regions depressed, the periphery subacute, and the whole test smaller than the typical form.

Chapman described the variety from off Port Phillip, Victoria, Australia. I have had a similar form from a depth of 12 fathoms off Levuka, Fiji, and off Niau.

\footnotetext{
18 Fichtel, Leopold von, and Moll, J. P. C. von, Testacea microscopica aliaque minuta ex generibus Argonauta et Nautilus ad naturam delineata et descripta, Testacea microscopica, p. 49, pl. 5, figs. c-e, 1798.

${ }^{20}$ Accad pontaniana Atti, vol. 7, pt. 2, pl. 19, figs. 15, 18, 1856.
}

Elphidium macellum (Fichtel and Moll) var. aculeatum (Silvestri) Cushman

Plate 15, figures 11-13

Polystomella macella (Fichtel and Moll) var. aculeata Silvestri, Accad. gioenia sci. nat. Boll. sed., 1900, fasc. 64, pp. 19-29, 2 figs. in text.

It is probable that this is the same as the form referred to by Fichtel and Moll as Nautilus strigillata, var. $\beta$, which had a very spinose periphery. Similar forms occur in the late Tertiary of southern Europe and on the coast of France and England. Their relationships are probably with $E$. macellum.

\section{Elphidium striato-punctatum (Fichtel and Moll) Cushman and Leavitt}

Plate 14, figures 6, 7

Nautilus striato-punctatus Fichtel and Moll, Testacea microscopica, p. 61, pl. 9, figs. a-c, 1798.

Elphidium striato-punctatum Cushman and Leavitt, Cushman

- Lab. Foram. Research Contr., vol. 5, p. 19, pl. 4, figs. $5,6,1929$.

Test of moderately large size for the genus, about twice as long as wide in peripheral view, the periphery broadly rounded, completely involute, umbilical regions flat or very slightly concave; chambers numerous, averaging 25 in the adult, later ones becoming somewhat wider than the earlier ones, last few chambers becoming inflated, forward part slightly raised, giving a radially ribbed appearance; sutures partly obscured by the retral processes, slightly depressed and indistinct in the earlier two-thirds of the coil, rather deeply depressed and distinct in the last part, earlier sutures nearly radial, later ones slightly and nearly symmetrically bowed forward, set with pores which are rather indistinct in the earlier part but large and deep on the last few sutures; wall finely perforate, with usually 12 relatively short, closely spaced retral processes, which appear to extend across the radial lines so that the processes form a more or less continuous line in the direction of coiling, appearing as low elevations in the earlier chambers, but in the last ones as relatively thick rodlike structures; aperture a row of small openings at the base of the apertural face (not a narrow slit as figured by Fichtel and Moll), apertural face slightly convex, crescentic, the sides ending in blunt points. Diameter of largest specimens $1 \mathrm{~mm}$; thickness 0.40 $\mathrm{mm}$.

The types of Fichtel and Moll are said to have come from the Arabian Gulf. The specimen figured here came from the Red Sea, where the typical form with broadly rounded periphery, a broad test in side view, and many chambers is often very abundant. This species does not seem to occur in the Mediterranean, and its distribution will probably be found to be confined to very warm, shallow waters of the Red Sea and adjacent parts of the Indian Ocean. Very many of the forms referred to this species certainly do not belong to it. As in other species, the last-formed 
chamber is very thin and probably broken by the formation of the young. For this reason the broader, more typical specimens were not chosen for figuring.

Although this species name has been used many times in the literature for both fossil and Recent species, until recently it has not been used correctly since the form was described by Fichtel and Moll. It seems to be a relatively local species. Some of the references to this species where the figures can be identified with certainty will be found in the synonymy of the species to which they apparently belong.

\section{Elphidium angulare (D'Orbigny) Cushman}

\section{Plate 14, figure 8}

Polystomella angularis D'Orbigny, Annales sci. nat., vol. 7, p. 284, no. 2, 1826.

Fornasini, Accad. sci. Ist. Bologna Mem., ser. 6, vol. 1, p. 12, pl. 3, figs. 7, 7a, 1904.

The first localities mentioned for this species by D'Orbigny in 1826 are Rawack and the Marianna Islands. No figures were published until the somewhat simplified copies of D'Orbigny's figures given by Fornasini. Copies of these figures are given on plate 14 . It is somewhat uncertain just what this species may be, but the figures are given here for reference.

\section{Elphidium owenianum (D'Orbigny) Cushman}

Plate 14, figures 9-12

Polystomella oweniana D'Orbigny, Voyage dans l'Amérique méridionale, vol. 5 , pt. 5, Foraminifères, p. 30, pl. 3, figs. $3,4,1839$.

Elphidium owenianum Cushman, U. S. Nat. Mus. Bull. 104, pt. 7, p. 21, pl. 8, figs. 10-12, 1929.

Cushman and Parker, U. S. Nat. Mus. Proc., vol. 80, art. 3, p. 11, 1931.

Heron-Allen and Earland, Discovery Repts., vol. 4, p. 441, pl. 16, figs. 31, 32, 1932.

Earland, Discovery Repts., vol. 7, p. 132, 1933.

Test of medium size for the genus, somewhat compressed, periphery subacute, margin entire, greatest thickness in peripheral view at the umbilical regions, which are not distinctly umbonate; chambers numerous, distinct, not inflated, averaging about 15 in the lastformed coil; sutures distinct, limbate, the retral processes elongate, rodlike, occupying almost the entire height of the chamber; aperture a series of rounded openings at the base of the apertural face. Diameter $0.75 \mathrm{~mm}$; thickness $0.30 \mathrm{~mm}$.

D'Orbigny described this species from the "coast of Patagonia, to the south of the Rio Negro." It is distinct from the other species of this region in its thickening at the umbilical region in peripheral view and the subacute margin and distinct sutures.

It has been recorded from the Falkland Islands at Port Howard and Port William and off Puerto Deseado, Argentina (Cushman and Parker); off the Falkland Islands (Heron-Allen and Earland); and off South Georgia (Earland).

\section{Elphidium lessonii (D'Orbigny) Cushman}

Plate 14, figures 13-16

Polystomella lessonii D’Orbigny, Annales sci. nat., vol. 7, no. 6, p. 284, 1826; Voyage dans l'Amérique méridionale, vol. 5, pt. 5, Foraminifères, p. 29, pl. 3, figs. 1, 2, 1839.

Fornasini, Accad. sci. Ist. Bologna Mem., ser. 6, vol. 1, p. 13, pl. 3, figs. 9, 9a, 1904.

Elphidium lessonii Cushman, U. S. Nat. Mus. Bull. 104, pt. 7, p. 22, pl. 9, figs. 1-4, 1930 .

Cushman and Parker, U. S. Nat. Mus. Proc., vol. 80, art. 3, p. 11, 1931.

Heron-Allen and Earland, Discovery Repts., vol. 4, p. 440, pl. 16, figs. 29, 30, 1932.

Earland, Discovery Repts., vol. 7, p. 132, 1933.

Cushman, Cushman Lab. Foram. Research Special Pub. 5, pl. 23, fig. 5, 1933.

Polystomella macella H. B. Brady (part) [not Fichtel and Moll], Challenger Rept., Zoology, vol. 9, pl. 110, fig. 9 [not figs. $8,10,111,1884$.

Test of large size for the genus, compressed, periphery rounded, margin very slightly lobulate, sides nearly parallel in peripheral view, umbilical regions not umbonate but occupied by a group of irregular raised areas; chambers numerous, 20 to 22 in the last-formed whorl, slightly inflated; sutures sigmoid, indistinct except as marked by the retral processes, which are prominent, elongate, rodlike, usually 15 or more, extending nearly the whole width of the chamber, the interspaces deep; aperture a series of rounded openings at the base of the apertural face. Diameter $1.20 \mathrm{~mm}$; thickness $0.35 \mathrm{~mm}$.

D'Orbigny's type locality for this species is given as "coast of Patagonia, to the south of Rio Negro." The type figure seems to show a young, immature specimen. It has been recorded from off the Falkland Islands (Brady, Cushman, Heron-Allen, and Earland) and from Puerto Deseado, Argentina (Cushman and Parker).

This is one of the most beautifully sculptured species that we have and very distinctive in its characters. It is probably limited in its distribution to the South Atlantic.

\section{Elphidium articulatum (D'Orbigny) Cushman}

Plate 14, figures 17-19

Polystomella articulata D'Orbigny, Voyage dans l'Amérique méridionale, vol. 5, pt. 5, Foraminifères, p. 30, pl. 3, figs. 9, 10, 1939.

Elphidium articulatum Cushman, U. S. Nat. Mus. Bull. 104, pt. 7, p. 26, pl. 10, figs. 6-8, 1930.

Cushman and Valentine, Stanford Univ., Dept. Geology, Contr., vol. 1, no. 1, p. 21, pl. 5, figs. 10 a, b, 1930.

Cushman and Parker, U. S. Nat. Mus. Proc., vol. 80, art. 3, p. 10, 1931.

Heron-Allen and Earland, Discovery Repts., vol. 4, p. 439, 1932.

Earland, Discovery Repts., vol. 7, p. 132, 1933.

Bermúdez, Soc. cubana historia nat. Mem., vol. 9, p. 188, 1935.

Elphidium incertum Heron-Allen and Earland [not Williamson], Discovery Repts., vol. 4, p. 439, pl. 16, figs. 20, 21, 1932.

Test small, somewhat compressed, periphery rounded, margin slightly lobulate, sides nearly parallel in pe- 
ripheral view, umbilical regions slightly depressed; chambers averaging 10 in the last-formed coil, slightly inflated; sutures slightly depressed, marked also by the retral processes, which are very short and broad, averaging 10 in number; aperture composed of several rounded openings at the base of the apertural face. Diameter $0.50 \mathrm{~mm}$; thickness $0.22 \mathrm{~mm}$.

D'Orbigny's types came from "the coast of Patagonia near the Rio Negro, and also from the Falklands." It is a smooth, polished species with a fairly thick wall which may be distinguished from $E$. poeyanum (D'Orbigny), of the West Indian region, which somewhat resembles it. Both of these species have been included under the name "Polystomella striato-punctata" but they are very different from that species, as has been noted.

In addition to the region of the Falkland Islands the species has been collected off St. Julian and off Puerto Deseado, Argentina (Cushman and Parker), South Georgia (Earland), and off Cuba (Bermúdez), and a very similar form seemingly identical has been found off California (Cushman and Valentine).

Elphidium articulatum (D'Orbigny), var. rugulosum Cushman and Wickenden

Plate 14, figure 20

Elphidium articulatum (D'Orbigny) var. rugulosum Cushman and Wickenden, U. S. Nat. Mus. Proc., vol. 75, art. 8, p. 7, pl. 3, figs. 8a, b, 1929.

Test bilaterally symmetrical, umbilicate, somewhat compressed, periphery rounded; about 9 chambers in the last-formed coil, slightly inflated; sutures slightly depressed, gently curved, somewhat filled with a rugose secondary growth which, over the umbilical region, fills that area; wall otherwise smooth, finely perforate; aperture consisting of an arched opening in the median line and a few smaller supplementary openings at either side. Diameter $0.30 \mathrm{~mm}$; thickness $0.12 \mathrm{~mm}$.

The types of this variety were found off Juan Fernandez.

This variety differs from the species described by D'Orbigny in the peculiar ornamentation of the sutures and the umbilical regions, and also in the aperture. In general shape and number of chambers it is very similar to D'Orbigny's species.

Elphidium alvarezianum (D'Orbigny) Cushman and Kellett

Plate 14, figures 21-23

Polystomella alvareziana D'Orbigny, Voyage dans l'Amérique méridionale, vol. 5 , pt. 5, Foraminifères, p. 31 , pl. 3, figs. $11,12,1839$.

Elphidium alvarezianum Cushman and Kellett, U. S. Nat. Mus. Proc., vol. 75, art. 25, p. 6, pl. 2, figs. 5a, b, 1929.

Cushman, U. S. Nat. Mus. Bull. 104, pt. 7, p. 18, pl. 7, figs. 1-3, 1930.

Cushman and Parker, U. S. Nat. Mus. Proc., vol. 80, art. 3, p. 12, 1931.

Heron-Allen and Earland, Discovery Repts., vol. 4, p. 440, pl. 16, figs. 24, 25, 1932.

Earland, Discovery Repts., vol. 7, p. 132, 1933.
Test much compressed, periphery subacute, not carinate, margin entire, even, sides nearly parallel in peripheral view, umbilical regions not umbonate; chambers not inflated, 10 to 12 or more in the last-formed coil; sutures not depressed, marked by the retral processes, which are short and broad, 7 to 8 in number; aperture composed of several rounded openings at the base of the apertural face. Diameter $0.60 \mathrm{~mm}$; thickness $0.20 \mathrm{~mm}$.

D'Orbigny's types came from "Patagonia, not far from the Rio Negro and in sands from the Falklands." Specimens of this same general form found as far north as the West Indies may also be placed in this species. It occurs only in this general region of the South Atlantic, so far as known.

\section{Elphidium alvarezianum (D'Orbigny) var. serrulatum Cushman and Parker}

Plate 14, figure 24

Elphidium alvarezianum (D'Orbigny) var. serrulatum Cushman and Parker, U. S. Nat. Mus. Proc., vol. 80, art. 3, p. 12, pl. 2, figs. 9a, b, 1931.

Variety differing from the typical form in the character of the periphery, which has definite toothlike projections, in the extreme form having each projection opposite the chambers divided into numerous serrations. Specimens in which the spinose projections are simple, connect this variety with the typical form.

The types of this variety were found off Port William, Falkland Islands.

In fully developed specimens this is a rather beautiful form that is very definitely related to D'Orbigny's species.

\section{Elphidium poeyanum (D'Orbigny) Cushman}

Plate 14, figures 25, 26

Polystomella poeyana D'Orbigny, in De la Sagra, Historia física, política y natural de la isla de Cuba, Foraminifères, p. 55, pl. 6, figs. 25, 26, 1839.

Cushman, Carnegie Inst. Washington Pub. 311, p. 55, pl. 9, figs. 9, 10, 1922; Pub. 344, p. 79, 1926.

Elphidium poeyanum Cushman, U. S. Nat. Mus. Bull. 104, pt. 7, p. 25, pl. 10, figs. 4, 5, 1930; Florida Geol. Survey Bull. 4, p. 39, pl. 7, figs. 3, 4, 1930.

Cole, Florida Geol. Survey Bull. 6, p. 36, 1931.

Cushman and Parker, U. S. Nat. Mus. Proc., vol. 80, art. 3, p. 10, 1931

Cushman and Ponton, Florida Geol. Survey Bull. 9, p. 69, 1932.

Cushman and Cahill, U. S. Geol. Survey Prof. Paper 175-A, p. 21, pl. 7, figs. 7a, b, 1933.

Bermúdez, Soc. cubana historia nat. Mem., vol. 9, p. 187, 1935.

Hadley, Elisha Mitchell Sci. Soc. Jour., vol. 52, no. 1, p. $35,1936$.

Test of small size for the genus, strongly compressed, periphery broadly rounded, margin slightly lobulate, sides nearly parallel in peripheral view, umbilical regions slightly depressed; chambers averaging 10 to 12 in the last-formed coil but variable, very slightly inflated, very distinct; sutures slightly depressed, 
marked by the very short, broad retral processes, averaging about 15 in number; wall thin, translucent, smooth, conspicuously but finely perforate; aperture composed of a series of small, rounded openings at the base of the apertural face. Diameter $0.50 \mathrm{~mm}$; thickness $0.20 \mathrm{~mm}$.

D'Orbigny described and figured this species from shore sands of Cuba and Jamaica. It has proved to be the most common species of the genus in the general West Indian region. It has been included under Polystomella striato-punctata but is very different from that species.

There is a considerable amount of variation in the specimens of this species, in the shape, which is often somewhat longer than broad, and especially in the number of the chambers. In its general characters, however, it is distinct from any other in the region.

Specimens from this region have undoubtedly been included by other authors under different names, but without figures or access to the original specimens it is difficult to place them with any certainty.

In our collections the species is represented as a Recent form from shallow water of San Juan Harbor and Ponce, Puerto Rico; Montego Bay, Jamaica; Biscayne Bay, Key West, and Dry Tortugas, Florida; off Tobago; St. Johns, Antigua ; and Rio de Janeiro Harbor, Brazil. The species is recorded from the Pleistocene and Pliocene of Florida by Cole and is very common in the Miocene of Florida and northward to Maryland.

\section{Elphidium sagrum (D'Orbigny) Cushman}

Plate 15, figures 1-3

Polystomella sagra D'Orbigny, in De la Sagra, Historia física, política y natural de la isla de Cuba, Foraminifères, p. 55, pl. 6, figs. 19, 20, 1839 .

Cushman, U. S. Nat. Mus. Bull. 103, p. 75, pl. 26, figs. 5a, b, 1918. Carnegie Inst. Washington Pub. 291, p. 49, 1919; U. S. Geol. Survey Prof. Paper 128-B, p. 71, pl. 11, figs. 20, 21, 1920.

Elphidium sagrum Cushman, U. S. Nat. Mus. Bull. 104, pt. 7, p. 24, pl. 9, figs. 5, 6, 1930.

Cole and Gillespie, Bull. Am. Paleontology, vol. 15, no. $57 \mathrm{~b}$, p. $10,1930$.

Cushman, Florida Geol. Survey Bull. 4, p. 40, pl. 7, figs. $6 a, b, 1930$.

Cushman and Parker, U. S. Nat. Mus. Proc., vol. 80, art. 3, p. 10, 1931.

Cole, Florida Geol. Survey Bull. 6, p. 37, pl. 4, fig. 5, 1931.

Cushman and Ponton, Florida Geol. Survey Bull. 9, p. 70, 1932.

Cushman and Cahill, U. S. Geol. Survey Prof. Paper 175-A, p. 22, pl. 7, figs. $9 \mathrm{a}, \mathrm{b}, 1933$.

Bermúdez, Soc. cubana historia nat. Mem., vol. 9, p. 188, 1935.

Polystomella lanieri Cushman [not D’Orbigny], U. S. Geol. Survey Prof. Paper 128-B, p. 72, pl. 11, fig. 22, 1920; U. S. Nat. Mus. Proc., vol. 59, p. 61, pl. 14, figs. 12, 13, 1921; Carnegie Inst. Washington Pub. 344, p. 80, 1926.

Test of small size for the genus, periphery broadly rounded, margin entire, not lobulate, sides convex in peripheral view, the last-formed portion wider than the earlier portions, umbilical regions depressed; chambers in the last portion slightly inflated, fairly distinct, 12 to 15 in the last-formed coil; sutures not depressed, except between the last few chambers, marked by the retral processes, about 10 in number, short and broad, continuous over the earlier portion of the test to form ridges slightly oblique to the periphery; wall fairly thick, perforate; aperture composed of a series of small, rounded openings at the base of the apertural face. Diameter $0.55 \mathrm{~mm}$; thickness $0.33 \mathrm{~mm}$.

The types came from shore sands of Cuba, recorded by D'Orbigny as rare. It is not nearly as common as a Recent species as some of the others of the West Indian region. There are specimens in our collection from off the Dry Tortugas, Florida, where it is rare; Habana Harbor and off Matanzas, Cuba; San Juan Harbor and Ponce, Puerto Rico; Runaway Bay and Montego Bay, Jamaica; off Somerset, Bermuda; and Rio de Janeiro Harbor, Brazil. It occurs in the Miocene of the gorge of Yumuri River, Matanzas, Cuba, in the Choctawhatchee, Chipola, and Oak Grove formations of Florida; and in the Duplin marl of North Carolina.

\section{Elphidium lanieri (D’Orbigny) Cushman}

\section{Plate 15, figure 4}

Polystomella lanieri D'Orbigny, in De la Sagra, Historia física, política y natural de la isla de Cuba, Foraminifères, p. 54, pl. 7, figs. 12, 13, 1839.

Cushman, Carnegie Inst. Washington Pub. 291, p. 49, 1919; U. S. Geol. Survey Prof. Paper 128-B, p. 72, pl. 11, fig. 22, 1920.

Elphidium lanieri Cushman, U. S. Nat. Mus. Bull. 104, pt. 7, p. 23 , pl. 9, fig. 7,1930 .

Bermúdez, Soc. cubana historia nat. Mem., vol. 9, p. 187, 1935.

Test of medium size for the genus, periphery subacute, margin entire, not lobulate; sides convex in peripheral view, giving a rhomboid outline to the test, umbilical regions each with a large rounded boss in peripheral view, forming the greatest width of the test but continuous with the sides; chambers not inflated, distinct, numerous, averaging 18 to 20 in the lastformed coil ; sutures not depressed, marked by the retral processes, which are short, 10 to 12 in number, and slightly oblique, those of the earlier portion tending to merge into oblique lines; wall smooth, distinctly perforate, translucent, the bosses of clear material with numerous tubular perforations; aperture composed of several small, rounded openings at the base of the apertural face. Diameter $0.60 \mathrm{~mm}$; thickness $0.40 \mathrm{~mm}$.

The types of D'Orbigny came from shore sands of Cuba. It is represented in our collections off the Dry Tortugas, Fla.; Runaway Bay and Montego Bay, Jamaica; Habana Harbor, Cuba, and from the Miocene of the gorge of the Yumuri River, Matanzas, Cuba.

In some of the earlier records I have combined this species with $E$. sagrum, but the two are really distinct. 
Elphidium discoidale (D'Orbigny) Cushman

Plate 15, figures 5-7

Polystomella discoidalis D'Orbigny, in De la Sagra, Historia física, política y natural de la isla de Cuba, Foraminifères, p. 56, pl. 6, figs. 23, 24, 1839.

Cushman, Carnegie Inst. Washington Pub. 311, p. 56, pl. 10, figs. 3, 1922; Pub. 344, p. 80, 1926.

Elphidium discoidale Cushman, U. S. Nat. Mus. Bull. 104, pt. 7, p. 22, pl. 8, figs. 8, 9, 1930.

Cushman and Cole, Cushman Lab. Foram. Research Contr., vol. 6, p. 97, pl. 13, figs. 10a, b, 1930.

Kornfeld, Stanford Univ., Dept. Geology, Contr., vol. 1, p. 88, pl. 16, figs. 3a, b, 1931.

Cole, Florida Geol. Survey Bull. 6, p. 34, 1931.

Bermúdez, Soc. cubana historia nat. Mem., vol. 9, p. 187, 1935.

Test of medium size for the genus, somewhat compressed, periphery subacute, margin slightly lobulate, sides convex in peripheral view, umbilical regions each with a large rounded boss, in peripheral view protruding strongly beyond the outline of the test; chambers only slightly inflated, distinct, averaging about 10 in the lastformed coil; sutures slightly depressed, somewhat broadening toward the inner end, marked also by the retral processes, which are short and 10 to 12 in number; wall smooth, very distinctly perforate, umbones of clear shell material, nearly transparent, with numerous coarse tubules; aperture composed of several small, rounded openings at the base of the apertural face. Diameter $0.65 \mathrm{~mm}$; thickness $0.30 \mathrm{~mm}$.

D'Orbigny described this species from shore sands of Cuba and Jamaica. It is particularly a species of shallow warm waters of the general West Indian region and the Gulf of Mexico. As a fossil it appears in the Pleistocene and Pliocene of the southern Atlantic Coastal Plain of the United States and rare in the Miocene Duplin marl of North Carolina and the St. Marys formation of Maryland. There are Recent specimens in our collections from the Dry Tortugas and other localities off southern Florida; Habana Harbor, Cuba; Montego Bay, Jamaica; San Juan Harbor, Puerto Rico; off St. Johns, Antigua; and Great Bahama Bank. All these localities are in relatively shoal water.

Elphidium oceanense (D'Orbigny) Cushman

Plate 15, figure 8

Polystomella oceanensis D'Orbigny, Annales sci. nat., vol. 7, p. 285 , no. $8,1826$.

Fornasini, Accad. sci. Ist. Bologna Mem., ser. 6, vol. 1, p. 13, pl. 3, figs. 10, 10a, 1904.

Fornasini gives a rough copy of the type figures on D'Orbigny's "planches inédites" which are copied on plate 15. The locality as given by D'Orbigny is the Atlantic coast of France.

From the incomplete data it is somewhat difficult to determine exactly what this species really is.

\section{Elphidium craticulatum (Fichtel and Moll) Cushman}

Plate 15, figures 14-17

Nautilus craticulatus Fichtel and Moll, Testacea microscopica, p. 51, pl. 5, figs. h-k, 1798.

Polystomella craticulata D'Orbigny, Annales sci. nat., vol. 7, p. 284, no. 3, 1826.

Carpenter, Introduction to Foraminifera, p. 279, pl. 16, figs. 1, 2, 1862.

H. B. Brady, Challenger Rept., Zoology, vol. 9, p. 739, pl. 110, figs. 16, 17, 1884.

Egger, K. bayer. Akad. Wiss. Abh., Cl. 2, vol. 18, p. 433, pl. 20, figs. 24, 25, 1893.

Millett, Royal Micr. Soc. Jour., 1904, p. 604.

Cushman, U. S. Nat. Mus. Bull. 71, pt. 4, p. 34, pl. 19, fig. 4, 1914.

Elphidium craticulatum Cushman, U. S. Nat. Mus. Bull. 161, pt. 2, p. 48, pl. 11, figs. 5a, b, 1933.

Test subglobose, composed of as many as 50 chambers in the last-formed coil; in face view broadly lenticular, about one and one-half times as long as wide, periphery bluntly rounded; umbilical region umbonate, filled with clear shell material for one-third or more of the diameter of the test, with large pores, rest of surface reticulate; aperture a long, narrow opening subdivided into a number of pores. Diameter up to $1.65 \mathrm{~mm}$; thickness $0.65 \mathrm{~mm}$.

This is typically a Recent species of the Indo-Pacific. The types came from the Arabian Sea. Our Recent collection includes specimens from the following localities: Malacca, India; Hong Kong Harbor and Eldad Reef, China Sea; Tacloban Anchorage, Philippines; off Cairns and off Murray Island, Great Barrier Reef, Port Denison, Queensland, Australia; depth 12 fathoms off Nairai, Fiji; and Vavau Anchorage, Tonga Islands. Rather typical species occur in the Pliocene of Benkoelen, Sumatra.

\section{Elphidium complanatum (D'Orbigny) Cushman}

Plate 15, figures 18, 19

Polystomella complanata D'Orbigny, in Barker-Webb and Berthelot, Histoire naturelle des îles Canaries, vol. 2, pt. 2, Foraminifères, p. 129, pl. 2, figs. 35, 36, 1839.

For this, as for the preceding species, no material has been available, and D'Orbigny's type figures are copied on plate 15. It also is recorded as rare in sands of the island of Teneriffe, in the Canaries. Until the types of this species, or at least topotype material, can be studied, they must be left in a very uncertain state.

\section{Elphidium berthelotianum (D'Orbigny) Cushman}

Plate 15, figure 20

Polystomella berthelotiana D'Orbigny, in Barker-Webb and Berthelot, Histoire naturelle des îles Canaries, vol. 2, pt. 2, Foraminifères, p. 129, pl. 2, figs. 31, 32, 1839.

This is one of the species described and figured by D'Orbigny from sands of Teneriffe, in the Canary Islands. A copy of the type figure is given on plate 
15. The species is recorded as rare. I have not had material from this locality, and there are no further records for it.

\section{Elphidium incertum (Williamson) Cushman}

\section{Plate 15, figures 21-24}

Polystomella umbilicatula var. incerta Williamson, Recent Foraminifera of Great Britain, p. 44, pl. 3, figs. 82, 82a, 1858.

Polystomella striato-punctata var. incerta Kiaer, Rept. Norwegian Fish. Mar. Invest., vol. 1, no. 7, p. 51, 1900.

Cushman, Rept. Canadian Arctic Exped., pt. M, p. 10, 1913.

Elphidium incertum Cushman, U. S. Nat. Mus. Bull. 104, pt. 7, p. 18, pl. 7, figs. 4-9, 1930; Florida Geol. Survey Bull. 4, p. 39, pl. 7, figs. 2a, b, 1930.

Cushman and Cole, Cushman Lab. Foram. Research Contr., vol. 6, p. 96, pl. 13, figs. 6, 7, 1930.

Cole, Florida Geol. Survey Bull. 6, p. 35, pl. 4, fig. 8, 1931.

Dolgopolskaya and Pauli, Station Biologique Karadagh Travaux, vol. 4, p. 37, pl. 3, figs. 15a, b, 1931.

Cushman and Parker, U. S. Nat. Mus. Proc., vol. 80, art. 3 , p. 10, 1931.

Cushman and Ponton, Florida Geol. Survey Bull. 9, p. 70, 1932.

Macfadyen, Geol. Mag., vol. 69, pl. 35, figs. 16a, b, 1932.

Cushman and Cahill, U. S. Geol. Survey Prof. Paper 175-A, p. 21, pl. 7, fig. 8, 1933.

Blake, Biological survey of the Mount Desert region, pt. 5, p. 76, 1933.

Shupack, Am. Mus. Novitates, no. 737, p. 12, pl., figs. 10a, b, 1934 .

Hadley, Elisha Mitchell Sci. Soc. Jour., vol. 52, no. 1, p. $35,1936$.

Polystomella decipiens Heron-Allen and Earland [not Costa], Linnean Soc. London Trans., ser. 2, vol. 11, p. 282, pl. 43, figs. 20-22, 1916.

Elphidium brooklynense Shupack, Am. Mus. Novitates, no. 737, p. 10, pl., figs. 7a, b, 1934 .

Elphidium florentinae Shupack, idem, p. 9, pl., figs. 5a, b.

Test of small size for the genus, compressed, periphery broadly rounded, margin entire or with the last two or three chambers lobulate, umbilical regions slightly depressed, often with a slight knob or irregularly arranged slits at the base of the sutures; chambers few, usually less than 10 in the last-formed whorl, slightly if at all inflated, distinct; sutures distinct, mainly marked by the openings, which are in a single row, retral processes very few, usually not more than 5 or 7 , distinct, the inner ends of the sutures slitlike; wall thick, usually opaque; aperture composed of several small, rounded openings at the base of the apertural face. Diameter $0.50 \mathrm{~mm}$; thickness $0.23 \mathrm{~mm}$.

The types of this species came from Scarborough, England. It is a cold-water species occurring in fairly deep water along the Continental Shelf from Cape Hatteras northward to Cape Cod, and thence it is found in shallower water northward to Iceland and across to Norway and the British Isles. A somewhat similar form is recorded from the Black Sea. Shupack records it from the Pleistocene of western Long Island. It occurs in the Pleistocene of Maryland and Florida, the Pliocene of Florida, and the Miocene of Florida (Choctawhatchee formation), of North Carolina and
South Carolina (Duplin marl), of Virginia (Yorktown and St. Marys formations), and of Maryland (St. Marys, Choptank, and Calvert formations). Macfadyen records it from the Pleistocene and Pliocene of East Anglia.

\section{Elphidium incertum (Williamson) var. clavatum Cushman}

$$
\text { Plate 16, figures, 1, } 2
$$

Elphidium incertum (Williamson) var. clavatum Cushman, U. S. Nat. Mus. Bull. 104, pt. 7, p. 20, pl. 7, figs. 10a, b, 1930. Blake, Biological survey of the Mount Desert region, pt. 5, p. 76, 1933.

Variety differing from the typical form in the ornamentation of the test, the umbilical portions being occupied by several large irregular bosses, very distinct but not forming a definite umbonate mass, test usually yellowish brown.

The types came from Spar Landing, Frenchmans Bay, Maine. Blake records it from the Mount Desert region of Maine. In our collections the variety occurs from Rhode Island northward and also is present on the coast of northern Europe, as follows: Beach sand, Newport, R. I.; Buzzards Bay, Mass.; Nantasket Beach, Hull, Mass.; Hampton Beach, N. H.; Penobscot Bay, Maine; cove between Lubec and Quoddy Head, Maine; off Eastport, Maine; beach sand, Metis Beach, Quebec, Canada; coast of Iceland; Grace Holman Harbor, Norway; and Kiollie Fjord, Norway.

It probably has been recorded from Europe as Polystomella striatopunctata.

Elphidium incertum (Williamson) var. mexicanum Kornfeld Plate 16, figure 3

Elphidium incertum (Williamson) var. mexicanum Kornfeld, Stanford Univ., Dept. Geology, Contr., vol. 1, p. 89, pl. 16 figs. 1, s, 1931.

Test equally biconvex, periphery narrowly rounded, umbilical region multiple or central, depressed or raised; chambers numerous, 10 to 12 in last-formed coil, the periphery varying from even curvature to slightly lobulate in the last-formed chambers; sutures distinct, slightly curved, depressed, each with a single row of numerous small, short, and narrow septal depressions; wall very finely perforate, smoothly finished, vitreous luster; aperture consisting of a row of circular openings at the base of the apertural face. Megalospheric form: Diameter, 0.32-0.38 $\mathrm{mm}$; thickness, $0.18 \mathrm{~mm}$. Microspheric form: Diameter, $0.32-0.39 \mathrm{~mm}$; thickness, $0.18 \mathrm{~mm}$.

The types of this variety came from the east end of Galveston Island, Galveston, Galveston County, Tex. It is common in shallow water of the Gulf coast of Texas and Louisiana.

The author remarks as follows:

The new variety is distinguished from $E$. incertum var. clavatum Cushman ${ }^{21}$ in the more elongate test; more narrowly rounded periphery; umbilical region either multiple or single, 10 to 12 chambers in the last-formed coil, as contrasted with 8 to 10 ;

${ }^{21}$ Cushman, J. A., The foraminifera of the Atlantic Ocean: U. S. Nat. Mus. Bull 104, pt. 7, (Nonionidae, Camerinidae, Peneroplidae, and Alveolinellidae, p. 20, pl. 7, figs. 10a-10b, 1930.) 
sutures more distinct; more finely perforate and more smoothly finished wall; and white vitreous translucent color. E. incertum var. clavatum is found on coasts of temperate regions fringing the Atlantic, while E. incertum var. mexicanum inhabits the more southerly waters of the Gulf of Mexico.

\section{Elphidium gibbum (Schultze) Cushman}

Plate 16, figures 4-6

Polystomella gibba Schultze, Organismus Polythalamiorum, p. 66, pl. 6, figs. 1-4, 1854 .

Under this name Schultze figures an Elphidium from Ancona, on the Adriatic. It is difficult from the figures given to know exactly what this species is. Copies of some of the original figures are given in plate 16 .

\section{Elphidium excavatum (Terquem) Cushman}

Plate 16, figures 7-12

Polystomella excavata Terquem, Essai sur le classement des animaux qui vivent sur la plage et dans les environs de Dunkerque, pt. 1, p. 25, pl. 2, figs. 2a-f, 1875 .

Elphidium excavatum Cushman, U. S. Nat. Mus. Bull. 104, pt. 7, p. 21, pl. 8, figs. 1-7, 1930 .

Earland, Discovery Repts., vol. 13, p. 58, 1936.

Polystomella umbilicatula Williamson [not Walker and Jacob], Recent Foraminifera of Great Britain, p. 42, pl. 3, fig. 81, 1858.

Test of small size for the genus, much compressed, periphery broadly rounded, margin entire or slightly lobulate, umbilical regions usually slightly depressed, sometimes with one or more small, rounded bosses; chambers few, 8 to 10 making up the last-formed coil, slightly if at all inflated; sutures distinct, very slightly depressed, marked by the very short, narrow retral processes with wide openings, between 8 and 10 in number, usually rather even and distinct; wall smooth; aperture composed of a row of small, rounded pores at the base of the apertural face. Diameter $0.40 \mathrm{~mm}$; thickness $0.12 \mathrm{~mm}$.

This species described and figured by Terquem from off the Atlantic coast of France seems to represent well a common species found on the coasts of Belgium and about the British Isles. It is somewhat like $E$. incertum (Williamson) but is more compressed, has the retral processes more even and in larger numbers, and the umbilical region is different. It has passed under the general name Polystomella striatopunctata but is not that species. Williamson's figured specimen referred to above is probably the same as Terquem's species. Earland records the species from the Weddell Sea.

\section{Elphidium venustum (Schultze) Cushman}

Plate 16, figures $13-15$

Polystomella venusta Schultze, Organismus Polythalamiorum, p. 67, pl. 6, figs. 7-9, 1854.

The type figures are here copied on plate 16 . The only record given by Schultze is from Ancona, on the Adriatic. The type figures show retral processes and openings only on the last two chambers of the test.
From these figures it is very difficult to determine this species satisfactorily.

Elphidium stella-boreale (Ehrenberg) Cushman

Plate 16, figures 16, 17

Geoponus stella-borealis Ehrenberg, K. preuss. Akad. Wiss. Abh., 1839, p. 132, pl. 1, figs. a-g.

Polystomella stella-borealis Schultze, Organismus Polythalamiorum, 1854, p. 67, pl. 6, figs. 5, 6.

The types of this species came from Cuxhaven, Germany. From the figures given it is difficult to place the species with any degree of certainty. Copies of Schultze's figures are given on plate 16 .

\section{Elphidium hedleyi (Jensen) Cushman}

Plate 16, figure 19

Polystomella hedleyi Jensen, Linnean Soc. New South Wales Proc., vol. 29, p. 828, pl. 23, fig. 14, 1904.

Has affinities with $P$. crispa and $P$. macella. It resembles the former in possessing a well-developed callus of supplementary skeleton infilling the umbilicus on either side, and the latter in being very thin and flat, $P$. crispa being rather inflated. It is variable in size but is usually considerably much larger than $P$. macella. As the figure shows, it differs from both the abovementioned genera in possessing a set of very minute skeletal bars of a third order which join the secondary. These show as a beautiful striation under the microscope. It often seems to be of a bluish color. The striation and flatness of the form constitute the main specific characteristics. The average diameter is about $1 \mathrm{~mm}$.

The description and figure of this species are not very complete but are quoted here from the author. The type came from beach sands, on Lizard Island, Great Barrier Reef, Queensland, Australia.

\section{Elphidium schmitti Cushman and Wickenden}

Plate 16, figure 18

Elphidium schmitti Cushman and Wickenden, U. S. Nat. Mus. Proc., vol. 75, art. 9, p. 7, pl. 3, figs. 9a-c, 1929.

Test bilaterally symmetrical, slightly compressed; periphery broadly rounded; about 7 chambers in the last-formed coil, inflated; sutures distinct, depressed, slightly curved, marked by a few small retral processes; wall smooth, finely perforate except the umbilical regions, which are covered by a coarsely granular ornamentation; apertures consisting of 3 or more small rounded openings at the base of the last-formed chamber close to the median line. Diameter $0.36 \mathrm{~mm}$; thickness $0.15 \mathrm{~mm}$.

The only record of this species is the type station, off Juan Fernandez.

\section{Elphidium milletti (Heron-Allen and Earland) Cushman}

Plate 16, figures 20-22

Polystomella verriculata Millett [not H. B. Brady], Royal Micr. Soc. Jour., 1904, p. 604, pl. 11, fig. 3.

Polystomella milletti Heron-Allen and Earland, Zool. Soc. London Trans., vol. 20, p. 735, pl. 53, figs. 38-42, 1915. 
Sidebottom, Royal Micr. Soc. Jour., 1918, p. 263.

Cushman, U. S. Nat. Mus. Proc., vol. 56, p. 633, 1919; Carnegie Inst. Washington Pub. 342, p. 48, pl. 16, figs. $7,8,1924$.

Heron-Allen and Earland, Linnean Soc. London Jour., Zoology, vol. 35, p. 640, 1924; Zool. Soc. London Trans., vol. 22 , p. 70 (list), 1926.

Elphidium milletti Cushman, U. S. Nat. Mus. Bull. 161, pt. 2, p. 49, pl. 11, figs. 8a, b, 1933 .

Bermúdez, Soc. cubana historia nat. Mem., vol. 9, p. 188, 1935.

Test compressed, periphery rounded and in side view lobulate; chambers inflated, increasing in size somewhat as added; sutures depressed, distinct; wall ornamented with fine spinose projections along the periphery, the main portion of the sides of the chambers having irregular, raised costae, which tend to form a chevronlike pattern with the angle opening toward the periphery; aperture at the base of the apertural face, indistinct. Length $0.55 \mathrm{~mm}$; breadth $0.45 \mathrm{~mm}$; thickness $0.20 \mathrm{~mm}$.

This species is apparently one of wide distribution in the Indo-Pacific region. Heron-Allen and Earland record it from 15 stations in the Kerimba Archipelago, off southeastern Africa, from Lord Howe Island in the Pacific, and from the Suez Canal. Millett records it from the Malay Archipelago. Sidebottom has recorded it from a depth of 465 fathoms off the east coast of Australia. I have had it from off the Poor Knights Islands, east coast of New Zealand; from Samoa; from 18 fathoms at Vavau Anchorage, Tonga Islands; and 12 fathoms off Nairai, Fiji. Bermúdez has recorded it from off the north coast of Cuba.

\section{Elphidium oceanicum Cushman}

Plate 16, figure 23

Elphidium oceanicum Cushman, U. S. Nat. Mus. Bull. 161, pt. 2, p. 52, pl. 12, figs. 7a, b, 1933.

Polystomella sp. (?) Cushman, Carnegie Inst. Washington Pub. 342 , p. 49, pl. 16, fig. 5, 1924.

Test rather small, nearly circular in side view, periphery broadly rounded, umbilical region depressed, and often with an irregularly raised pattern; chambers distinct, very slightly inflated, of uniform shape and increasing very slightly, depressed, the retral processes very distinct but occupying only a narrow band above the sutures; wall translucent, very finely perforate; aperture consisting of one or more openings at the base of the apertural face. Diameter $0.35-0.45 \mathrm{~mm}$; thickness $0.12-0.15 \mathrm{~mm}$.

The types of this species came from Levuka, Fiji, in 12 fathoms. It was recorded from Samoa without specific name. It is apparently a species of shoal water. It also occurs in 3 fathoms at Viva Anchorage, Fiji; 12 fathoms off Nairai, Fiji; Mokaujar Anchorage, Fiji; and 18 fathoms at Vavau Anchorage, Tonga Islands.

This is a small but distinctive species, apparently widely distributed in the Pacific.

\section{Elphidium reticulosum Cushman}

Plate 16, figure 24

Elphidium reticulosum Cushman, U. S. Nat. Mus. Bull. 161, pt. 2, p. 51, pl. 12, figs. 5a, b, 1933.

Test compressed, umbilical region excavated, periphery broadly rounded, in side view the later portion strongly lobulate, no definite keel developed; chambers increasing in size as added, rather rapidly in the lastformed portion, and becoming much inflated; sutures distinct, depressed, especially in the later portion, retral processes in the early portion occupying a large part of the chamber width, in the later portion very much reduced in relative size on account of the great increase in the width of the chambers; wall ornamented by peculiar depressions of the surface, forming a very fine network or reticulation; aperture formed by numerous small pores at the base of the apertural face. Diameter $0.55 \mathrm{~mm}$; thickness $0.18 \mathrm{~mm}$.

The types of this species came from Vavau Anchorage, Tonga Islands, in 18 fathoms.

The species also occurs in typical form at Rotonga in 7 fathoms. The wall of this species is very peculiar in its ornamentation, being a very fine network of irregular pattern, entirely covering the inflated chambers. This form is hardly to be confused with any other species from the South Pacific.

\section{Elphidium morenoi Bermúdez}

Plate 16, figure 29

Elphidium morenoi Bermúdez, Soc. cubana historia nat. Mem., vol. 9, p. 188, pl. 13, figs. 7-9, 1935.

Test planispiral, involute, much compressed, periphery broadly rounded, almost truncate; chambers numerous, 12 to 15 in the adult coil, somewhat inflated, increasing very slightly in size as added; sutures slightly curved, very slightly depressed; wall with radiating lines of small circular beads from the umbilical region, which is covered with similar beads; aperture consisting of numerous small rounded openings at the base of the apertural face. Diameter $0.70-1.00 \mathrm{~mm}$ or more: thickness $0.30-0.40 \mathrm{~mm}$.

The types of this highly ornate species were found off the north shore of Cuba. The figure on plate 16 shows a cotype. I have a single specimen from Rio de Janeiro Harbor, Brazil. It is very common in collections I made at Key West, Fla., and therefore probably has a fairly wide range in the general West Indian region.

Elphidium selseyense (Heron-Allen and Earland) Cushman

Plate 16, figures 26-28

Polystomella striatopunctata (Fichtel and Moll) var. HeronAllen and Earland, Royal Micr. Soc. Jour., 1909, p. 695, pl. 21, figs. 2a-c. 
Polystomella striatopunctata (Fichtel and Moll) var. selseyensis Heron-Allen and Earland, Royal Micr. Soc. Jour., 1909, p. 448; Zool. Soc. London Trans., vol. 20, p. 733, 1915; Linnean Soc. London Trans., ser. 2, vol. 11, p. 282, 1916; British Antarctic Exped., Zoology, vol. 6, p. 229, 1922; Royal Micr. Soc. Jour., vol. 50, p. 193, 1930.

The original figures are copied on plate 16 . The test is partially evolute, with inflated chambers and depressed sutures, very short retral processes, a rounded periphery, and the umbilical region "more or less filled in with a vesicular extension of the final whorl of chambers, thus presenting as it were a secondary deposit of chamberlets in the middle of the shell." Diameter about $0.60 \mathrm{~mm}$; thickness $0.18-0.20 \mathrm{~mm}$.

This form was figured from Selsey Bill, off the south coast of England, and also recorded from Bognor, in the same region. It has been recorded by the authors from about the British Isles and also without figures from the Kerimba Archipelago, off southeastern Africa, and from the Antarctic. It is evidently not related to Fichtel and Moll's species.

\section{Elphidium gunteri Cole var. galvestonense Kornfeld}

\section{Plate 16, figure 25}

Polystomella galvestonensis Applin [name only], Am. Assoc. Petroleum Geologists Bull., vol. 9, p. 84, 1925.

Elphidium gunteri Cole var. galvestonensis Kornfeld, Stanford Univ., Dept. Geology, Contr., vol. 1, p. 87, pl. 15, figs. 1-3, 1931.

Test of medium size, biconvex, periphery rounded; umbilical region multiple or central, flattened to very slightly convex; chambers numerous, 13 to 18 in the last-formed coil; sutures depressed to limbate, bridged by a double row of small, closely spaced, transverse crenulations, frequently with a regular series of ridges crossing the sutures externally; wall very finely perforate; aperture a series of pores above and along the base of the apertural face. Diameter, microspheric form, $0.35-0.43 \mathrm{~mm}$; thickness $0.18-0.19 \mathrm{~mm}$; diameter, megalospheric form, 0.48-0.57 mm; thickness $0.28 \mathrm{~mm}$.

The types came from the east end of Galveston Island, Galveston, Galveston County, Tex. The species is recorded as common in the shallow, subtropical waters of the Gulf of Mexico from the Rio Grande to the Mississippi River. It is also recorded from well samples of the late Tertiary of Texas and Louisiana.

The variety differs from the typical form in its larger number of chambers, depressed sutures, and very finely perforate wall.

\section{Elphidium australe Cushman and Parker}

Plate 16, figure 30

Elphidium australis Cushman and Parker, U. S. Nat. Mus. Proc., vol. 80, art. 3, p 12, pl. 2, figs. 8a, b, 1931.

Test planispiral, nearly completely involute, the periphery very broadly rounded and in the last-formed portion almost truncate; chambers very distinct, 12 to 15 in the last-formed coil, of nearly uniform shape and increasing only slightly in size as added; sutures deep, very distinct; retral processes very short and often inconspicuous; wall of the main body of the chamber smooth except in the early portion of the last-formed coil, where it is often roughened by small papillae arranged more or less in longitudinal lines in the plane of coiling, umbonal region also strongly papillate; aperture consisting of numerous small circular pores at the base of the apertural face, which is smooth, with a distinct border about its periphery. Diameter 0.50 $0.60 \mathrm{~mm}$; thickness $0.25 \mathrm{~mm}$.

The types of this species were obtained off Port Stanley, Falkland Islands.

Although this species was found to be common at the type station, it was lacking in material from other stations in the region. It is evidently a distinct species of local distribution.

\section{Elphidium advenum (Cushman) Cushman}

Plate 16, figures $31-35$

Polystomella subnodosa H. B. Brady [not Von Münster], Challenger Rept., Zoology, vol. 9, p. 734, pl. 110, figs. 1a, b, 1884.

Chapman, Linnean Soc. London Jour., Zoology, vol. 28, p. 203, 1902.

Millett, Royal Micr. Soc. Jour., 1904, p. 604.

Bagg, U. S. Nat. Mus. Proc., vol. 34, p. 165, 1908.

Heron-Allen and Earland, Zool. Soc. London Trans., vol. 20, p. $733,1915$.

Polystomella advena Cushman, Carnegie Inst. Washington Pub. 311, p. 56, pl. 9, figs. 11, 12, 1922; Pub. 342, p. 48, 1924; Pub. 344, p. 80, 1926.

Elphidium advenum Cushman, U. S. Nat. Mus. Bull. 104, pt. 7, p. 25, pl. 10, figs. 1, 2, 1930; Florida Geol. Survey Bull. 4, p. 40, pl. 7, figs. 7a, b, 1930.

Cushman and Parker, U. S. Nat. Mus. Proc., vol. 80, art. 3, p. 11, 1931.

Chapman, Great Barrier Reef Comm. Repts., vol. 3, pp. 34-41 (lists), 1931.

Cushman and Ponton, Florida Geol. Survey Bull. 9, p. 70, pl. 11, figs. 1a, b, 1932.

Cushman, U. S. Nat. Mus. Bull. 161, pt. 2, p. 50, pl. 12, figs. 1-3, 1933.

Cushman and Cahill, U. S. Geol. Survey Prof. Paper 175-A, p. 22, pl. 7, figs. 10a, b, 1933.

Palmer and Bermúdez, Soc. cubana historia nat. Mem., vol. 9, p. 246, 1935.

Test of medium size for the genus, strongly compressed, periphery acute, with a narrow carina, somewhat lobulate, sides nearly parallel in peripheral view, umbilical regions depressed, often with a small central boss of clear shell material but in peripheral view not projecting beyond the contour of the test; chambers distinct, 10 to 15 in the last-formed coil, slightly inflated, especially in the last-formed portion; sutures depressed, marked by the retral processes which are short, about one-fourth the width of the chamber, 12 to 15 in number; wall smooth, translucent, finely and distinctly perforate; aperture composed of a series of small rounded pores at the base of the apertural face. Diameter up to $0.50 \mathrm{~mm}$; thickness $0.15 \mathrm{~mm}$.

This species was originally described from the Tortugas region of southern Florida. It is widely distrib- 
uted in warm waters of both the western Atlantic andthe Pacific. As a fossil it occurs in the Miocene Choctaw hatchee, Chipola, Oak Grove, and Shoal River formations of Florida and the Duplin marl of South Carolina, and in the Tertiary of the Matanzas Bay region of Cuba. Chapman records it from borings in the Great Barrier Reef of Australia. Recent material is in our collection from the Dry Tortugas and Key West, Fla., San Juan Harbor and Ponce, Puerto Rico ; off Matanzas, Cuba; Rio de Janeiro Harbor, Brazil; off Fiji, Tonga, and Paumotus, in the Pacific.

\section{Elphidium advenum (Cushman) var. depressulum Cushman}

\section{Plate 17, figure 1}

Elphidium advenum (Cushman) var. depressulum Cushman, U. S. Nat. Mus. Bull. 161 , pt. 2 , p. 51 , pl. 12 , figs. $4 a$, b, 1933.

Variety differing from the typical form in the umbilical region, which is depressed and without a definite boss, occupied by a few large pits, the periphery more lobulate and much sharper, with a more distinct keel; chambers fewer, broader, and somewhat more inflated.

The variety is common at the type locality, Vavau Anchorage, Tonga Islands. It is also known from 7 fathoms, Rotonga, and 3 fathoms, Viva Anchorage, Fiji. It is probably widely distributed in shallow water of the Pacific.

Elphidium advenum (Cushman) var. margaritaceum Cushman

\section{Plate 17, figure 2}

Elphidium advenum (Cushman) var. margaritaceum Cushman, U. S. Nat. Mus. Bull. 104, pt. 7, p. 25, pl. 10, fig. 3, 1930.

Cushman and Cole, Cushman Lab. Foram. Research Contr., vol. 6, p. 97, 1930.

?Polystomella striatopunctata Bagg [not Fichtel and Moll], Maryland Geol. Survey, Pliocene and Pleistocene, p. 216, pl. 66, figs. 14, 15, 1906.

Variety differing from the typical form mainly in the character of the wall, which is pearly and coarsely perforate, giving a very distinctive appearance to the test.

The types of the variety came from beach sand at Newport, R. I. It also occurs in the Pleistocene of Wailes Bluff, Md. The variety is apparently a more northern development of the typical form.

\section{Elphidium advenum (Cushman) var. ponticum Dolgopolskaja and Pauli}

Plate 17, figure 3

Elphidium (Polystomella) advenum (Cushman) var. pontica Dolgopolskaja and Pauli, Sta. Biol. Karadagh Travaux, vol. 4, p. 36, pl. 3, figs. 14a, b, 1931.

The types of this species came from the Black Sea. Copies of the figures are given on plate 17, but the description is in Russian.
Elphidium imperatrix (H. B. Brady) Cushman

Plate 17, figures 5-9

Polystomella imperatrix H. B. Brady, Quart. Jour. Micr. Sci.,vol.21, p. 66, 1881; Challenger Rept., Zoology, vol. 9, p. 738, pl. 110, figs. 13-15, 1884.

Pearcey, Royal Soc. Edinburgh Trans., vol. 49, p. 1031, 1914. Sidebottom, Royal Micr. Soc. Jour., 1918, p. 263.

Test very much compressed, sides flattened, periphery subacute, with a few short, acerose spines, usually only 4 or 5 ; chambers distinct, numerous, about 20 in the adult coil, of rather uniform shape, increasing gradually in size as added, outer edge along the apertural face slightly angled; sutures distinct, slightly depressed, curved or slightly sigmoid, retral processes numerous, 15 or more on each side of the adult chamber, slightly oblique, sometimes anastomosing; wall reticulate; aperture a low opening at the base of the apertural face, sometimes partially subdivided. Diameter up to $1.70 \mathrm{~mm}$; thickness $0.35 \mathrm{~mm}$.

Brady records the species from Storm Bay, Tasmania, and from Port Jackson, in 2 to 10 fathoms. Pearcey records it from a depth of $2 \frac{1}{4}$ fathoms, Stanley Harbor, Falkland Islands, and Sidebottom from 465 fathoms off the east coast of Australia. Howchin refers specimens from the Tertiary of Australia to this species but notes that they are "not very characteristic." Protescu ${ }^{22}$ has referred specimens from the Tertiary of Rumania to this species, but they are different in their spines and not so compressed. For future reference copies of the rather poor figures are given on plate 17 .

\section{Elphidium verriculatum (H. B. Brady) Cushman}

Plate 17, figure 13

Polystomella verriculata H. B. Brady, Quart. Jour. Micr. Sci., vol.21, p. 66, 1881; Challenger Rept., Zoology, p. 738, pl. 110, figs. $12 \mathrm{a}, \mathrm{b}, 1884$.

Chapman, Quekett Micr. Club Jour., ser. 2, vol. 10, p. 142, pl. 10, fig. 10, 1907.

Test much compressed, sides flattened, periphery acute, slightly keeled; chambers fairly distinct, 12 to 15 in number, increasing rather rapidly in size as added; sutures raised, strongly curved; retral processes raised, 8 or 9 in the adult chamber, slightly oblique; wall strongly reticulate; aperture simple or slightly notched. Diameter $0.50 \mathrm{~mm}$; thickness $0.12 \mathrm{~mm}$.

Brady's specimens were found in 38 fathoms off East Moncoeur Island, Bass Strait, Australia, and in Curtis Strait, Queensland. Chapman records it from Beaumaris, off Port Phillip, Victoria, Australia, as rare. There are a few other records for the species from other regions, but those accompanied by figures seem not to be the same.

22 Protescu, O., Contribuțiuni la studiul faunei de foraminifere Terţiare din România: Inst. geol. Romaniel Anuar., vol. 9, 1915-20, p. 347, pl. 4, figs. 2, 3, 1922. 


\section{Elphidium simplex Cushman}

Plate 17, figure 10

Elphidium simplex Cushman, U. S. Nat. Mus. Bull. 161, pt. 2, p. 52, pl. 12, figs. $8,9,1933$.

Test nearly circular in side view, periphery rounded, becoming very slightly lobulate in the later portion in side view, umbilical region occupied by a large flat boss; chambers numerous, distinct, 10 to 12 in the last-formed coil, of rather uniform shape, increasing very slightly in size as added, the later ones slightly inflated; sutures distinct, depressed, rather strongly curved, retral processes often indistinct but usually visible, especially in the later chambers; aperture one or more openings at the base of the apertural face. Length up to $0.55 \mathrm{~mm}$; breadth $0.45 \mathrm{~mm}$; thickness $0.15 \mathrm{~mm}$.

The types of this species came from Vavau Anchorage, Tonga Islands, where it occurs abundantly. It also occurs in 12 fathoms at Levuka, Fiji; 12 fathoms off Nairai, Fiji; 3 fathoms at Viva Anchorage, Fiji; and 7 fathoms off Rotonga. It is a rather simple primitive form in which the retral processes are very slightly developed. It is so abundant at some of the stations that it is doubtless a characteristic Indo-Pacific species.

Elphidium minimum (Seguenza) Cushman

Plate 17, figure 4

Polystomella minima Seguenza, R. Accad. Lincei Atti, ser. 3, vol. 6 , p. 333 , pl. 17 , figs. 38,38 a, 1880 .

Although there are no specimens in our collections that seem identical with that described by Seguenza from the Pliocene of Sicily, copies of his figures are given on plate 17 .

\section{Elphidium magellanicum Heron-Allen and Earland}

Plate 17, figures 11, 12

Elphidium (Polystomella) magellanicum Heron-Allen and Earland, Discovery Repts., vol. 4, p. 440, pl. 16, figs. 26-28, 1932.

Test free, hyaline, compressed, exhibiting 5 to 6 chambers in the outer convolution. Sutures strongly depressed, chambers slightly inflated, giving a markedly lobulate peripheral edge. The sutural depressions are filled with very finely granular matter, giving a somewhat snowlike surface, contrasting strongly with the inflated glassy chambers, which are generally quite transparent. Underneath the granular snowlike matter in the sutures, the "fossettes" are concealed, but in young specimens they are plainly visible. Dimensions, breadth up to $0.35 \mathrm{~mm}$; width $0.30 \mathrm{~mm}$; thickness at oral face $0.12 \mathrm{~mm}$.

The types of this species came from depths of 23 and 82 meters at the eastern entrance to the Straits of Magellan. These are the only records for the species. Copies of the type figures are given on plate 17 .

Elphidium jenseni (Cushman) Cushman

Plate 17, figures 14,15

Polystomella macella (Fichtel and Moll) var. Jensen, Linnean Soc. New South Wales Proc., vol. 29, p. 817, pl. 23, fig. 4, 1904 [1905].
Polystomella jenseni Cushman, Carnegie Inst. Washington Pub. 342 , p. 49 , pl. 16, figs. 4 (?), 6, 1924.

Elphidium jenseni Cushman, U. S. Nat. Mus. Bull. 161, pt. 2, p. 48, pl. 11, figs. 6, 7, 1933.

Test very strongly compressed, periphery very slightly keeled; chambers numerous, distinct, not inflated; sutures distinct, somewhat raised, retral processes elongate, thin, bridging almost entirely the area between the sutures with flat depressed areas between, umbilical area finely papillate. Length up to $0.60 \mathrm{~mm}$; breadth $0.45 \mathrm{~mm}$; thickness $0.10 \mathrm{~mm}$.

Jensen originally described this species from a depth of 100 fathoms off Australia. I have recorded it from shallow water off Samoa; from Vavau Anchorage, Tonga Islands, 18 fathoms; Mokaujar Anchorage, Fiji; Levuka, Fiji, 12 fathoms; Nairai, Fiji, 12 fathoms; Rongelab Atoll, Marshall Islands; and Guam Anchorage, Ladrone Islands, 21 fathoms. I found the species in a few Albatross stations in the South Pacific in fairly deep water but close to islands, from which the specimens were carried out by currents.

Elphidium indicum Cushman

Plate 17 , figure 16

Elphidium indicum Cushman, Cushman Lab. Foram. Research Contr., vol. 12, p. 83, pl. 14, figs. 10a, b, 1936.

Test somewhat compressed, distinctly umbonate, rhomboid in peripheral view, periphery rounded; chambers fairly distinct, later ones slightly inflated, about 15 in the adult coil, of rather uniform size and shape; sutures in the earlier portion indistinct, later more distinct and slightly depressed, very slightly curved, retral processes, 12 to 15 in the adult, short; wall highly ornate, early portion with rounded continuous costae parallel to the periphery, in the later chambers becoming somewhat oblique and limited to each chamber; aperture a series of small openings at the base of the high, arched apertural face. Diameter $0.80 \mathrm{~mm}$; thickness $0.40 \mathrm{~mm}$.

The types of this species came from shore sand at Bombay, India.

\section{Elphidium lidoense Cushman}

Plate 17, figure 17

Elphidium lidoense Cushman, Cushman Lab. Foram. Research Contr., vol. 12, p. 86, pl. 15, figs. 6a, b, 1936.

Test moderately compressed, sides flattened, umbilical region with numerous irregular bosses, periphery broadly rounded; chambers very distinct, slightly inflated, about 10 in the adult coil, increasing gradually in size as added; sutures very distinct, slightly depressed, distinctly broadening toward the inner margin, retral processes short, small, indistinct, 10 or more in the adult chamber; wall distinctly perforate, smooth except for the bosses of the umbilical region and a series of small papillae at each side of the earliest 
exposed chambers; aperture a low opening at the base of the semielliptical apertural face. Diameter 0.50$0.60 \mathrm{~mm}$; thickness $0.22 \mathrm{~mm}$.

The types of this species came from beach sand at Lido, Venice, Italy.

\section{Elphidium earlandi Cushman}

Plate 18, figure 1

Elphidium earlandi Cushman, Cushman Lab. Foram. Research Contr., vol. 12, p. 85, pl. 15, figs. 5a, b, 1936.

Test very strongly compressed, sides tlattened or slightly concave, periphery in the earlier portion slightly keeled, in the later portion rounded, very slightly lobulate; chambers distinct, few, 8 or 9 in the adult coil, increasing rapidly in size as added, later ones slightly inflated; sutures distinct, very strongly curved, retral processes distinct, short, covering only one-third of the chamber, 12 to 15 in the adult chamber; wall otherwise smooth. Diameter $0.50 \mathrm{~mm}$; thickness $0.08-$ $0.10 \mathrm{~mm}$.

The types were found in material dredged by the steam trawler Engineer off the southwest coast of Spain.

\section{Elphidium novo-zealandicum Cushman}

Plate 17, figure 18

Elphidium novo-zealandicum Cushman, Cushman Lab. Foram. Research Contr., vol. 12, p. 85, pl. 15, figs. 4a, b, 1936.

Test much compressed, umbilical region depressed, with a reticulate ornamentation, periphery subacute, with a fairly broad rounded keel, not lobulate; chambers distinct, numerous, 20 or more in the adult coil, not inflated, outer rim slightly thickened and slightly raised, thence slightly sloping to the previous suture, of uniform shape, increasing very gradually in size; sutures distinct, slightly depressed, gently curved, retral processes distinct, running entirely across the chamber, about 15 in the adult chamber; aperture consisting of numerous small rounded openings at the base of the narrowly heart-shaped apertural face. Diameter 0.60$0.65 \mathrm{~mm}$; thickness $0.20 \mathrm{~mm}$.

The types of this species came from dredgings in Dusky Sound, New Zealand.

\section{Elphidium nigarense Cushman}

Plate 17, figure 19

Elphidium nigarense Cushman, Cushman Lab. Foram. Research Contr., vol. 12, p. 85, pl. 15, figs. 3a, b, 1936.

Test much compressed, umbilical regions depressed, periphery acute, sharply keeled, slightly lobulate; chambers distinct, 10 to 12 in the adult coil, not inflated, outer rim thickened and sharply raised, thence sloping to the previous suture, of rather uniform shape, increasing gradually in size as added; sutures fairly distinct, depressed, strongly curved, retral processes distinct, running nearly across the chamber, about 8 1819-39-5 or 9 in the adult chamber; aperture consisting of several small rounded openings at the base of the sharply triangular apertural face. Diameter $0.45-0.50 \mathrm{~mm}$; thickness $0.15 \mathrm{~mm}$.

The types came from dredgings off Nigare, Greece.

\section{Elphidium hispidulum Cushmar}

Plate 18, figure 2

Elphidium hispidulum Cushman, Cushman Lab. Foram. Research Contr., vol. 12, p. 83, pl. 14, figs. 13a, b, 1936.

Test somewhat compressed, elliptical in peripheral view, slightly umbonate, periphery rounded; chambers mostly indistinct, the last 2 or 3 slightly inflated, about 10 in the adult coil, of rather uniform size and shape; sutures in the early portion with a row of low papillae, later smoother and slightly depressed, slightly curved; wall finely spinose, umbo with a few raised bosses of irregular size, early portion of test with fine rounded costae parallel to the periphery, later nearly obsolete; aperture consisting of several small openings at the base of the rounded, triangular apertural face. Diameter $0.50 \mathrm{~mm}$; thickness $0.20 \mathrm{~mm}$.

The types came from depths of 4 to 14 fathoms in Albany Passage, Australia.

\section{Elphidium spinatum Cushman and Valentine}

\section{Plate 18, figures 3,4}

Elphidium spinatum Cushman and Valentine, Stanford Univ., Dept. Geology, Contr., vol. 1, no. 1, p. 21, pl. 6, figs. 1, $2,1930$.

Cushman and Moyer, Cushman Lab. Foram. Research Contr., vol. 6, p. 56, 1930.

Test compressed, completely involute, periphery in the adult rounded and set with short spines, especially on the later chambers, extending forward obliquely from the anterior margin of the periphery of the chamber in a somewhat tangential direction; chambers numerous, 11 to 13 in the last-formed coil, distinct, only slightly inflated in the last half coil; sutures slightly if at all depressed, marked by the retral processes, usually 7 or 8 in number, short; wall very finely perforate; aperture very small, at the base of the apertural face. Diameter $0.70-0.80 \mathrm{~mm}$; thickness $0.25 \mathrm{~mm}$.

This is a very beautiful species occurring off the coast of southern California and so far not known elsewhere.

\section{Elphidium subevolutum Cushman}

\section{Plate 18, figure 5}

Elphidium subevolutum Cushman, U. S. Nat. Mus. Bull. 161, pt. 2, p. 52, pl. 12, figs. 6a, b, 1933.

Test very strongly compressed, the early coils not covered as the test becomes evolute, periphery acute and distinctly keeled; chambers numerous, strongly inflated, of nearly uniform shape, and increasing only slightly in size as added, retral processes very narrow, occupying but a narrow band above the sutures, which 
are strongly depressed; wall smooth, finely perforate; aperture consisting of a few pores at the base of the apertural face, indistinct. Length $0.50 \mathrm{~mm}$; breadth $0.45 \mathrm{~mm}$; thickness $0.12 \mathrm{~mm}$.

The species is known only from a depth of 7 fathoms off Rotonga, in the South Pacific, but is abundant there. It is one of the few species that is strongly evolute; most of the others also have a Pacific distribution.

\section{Elphidium papillosum Cushman}

\section{Plate 18, figure 6}

Elphidium papillosum Cushman, Cushman Lab. Foram. Research Contr., vol. 12, p. 83, pl. 14, figs. 12a, b, 1936.

Test compressed, elliptical in peripheral view, periphery rounded in the young, becoming subacute in the adult; chambers and sutures obscured by the ornamentation of the surface, which consists of irregularshaped bosses, more rounded in the earlier portion, on the later chambers fusing and becoming irregularly broken costae; aperture consisting of a few small openings at the base of the curved apertural face. Diameter $0.60 \mathrm{~mm}$; thickness $0.25 \mathrm{~mm}$.

The types of this species were obtained at a depth of 100 fathoms 16 miles east of Wollongong, New South Wales.

\section{Elphidium sculpturatum Cushman}

Plate 18, figure 7

Elphidium sculpturatum Cushman, Cushman Lab. Foram. Research Contr., vol. 12, p. 84, pl. 15, figs. 2a, b, 1936.

Test moderately compressed, rhomboid in peripheral view, slightly umbonate, periphery subacute, slightly keeled; chambers distinct, about 12 in the final coil, not inflated, outer rim raised, thence sloping to the previous sutures, of uniform shape, increasing very gradually in size as added; sutures fairly distinct, slightly depressed, strongly curved, last ones slightly sigmoid, retral processes very distinct, running clear across the chamber, about 8 in the adult chamber; aperture consisting of several small rounded openings at the base of the broadly triangular apertural face. Diameter $0.45-0.50 \mathrm{~mm}$; thickness $0.22-0.25 \mathrm{~mm}$.

The types came from dredgings off Black Rock, near Melbourne, Victoria, Australia.

\section{Elphidium frigidum Cushman}

Plate 18, figure 8

Elphidium frigidum Cushman, Smithsonian Misc. Coll., vol. 89, no. 4, p. 5, pl. 1, figs. 8a, b, 1933.

Test usually completely involute, periphery rounded, sides flattened; chambers distinct, slightly inflated, the last ones distinctly so, final chambers often enlarged and projecting beyond the general contour of the test; sutures distinct, depressed, with very numerous short retral processes; wall thin, very distinctly perforate, the last-formed chambers of ten having distinct elongate markings; aperture consisting of numerous fine pores at the base of the apertural face of the last-formed chamber. Length $0.90 \mathrm{~mm}$; thickness $0.25 \mathrm{~mm}$.

The types were found at depths of 25 fathoms in the center of Fox Basin. Except for one station off Greenland, at 10 to 35 fathoms, near Shannon Island, the species has been found only in the stations in Fox Basin as follows: 34 to 37 fathoms, southeast corner of Fox Basin, latitude $66^{\circ} 46^{\prime}$ N., longitude $69^{\circ} 15^{\prime} \mathrm{W}$.; and Fox Basin, latitude $66^{\circ} 43^{\prime}$ N., longitude $80^{\circ} 07^{\prime} \mathrm{W}$., where it is common. It shows considerable variation in the shape of the last-formed chamber, which is much expanded in the adult and often longer than the others, so that it projects beyond the general outline of the test. The apertural face of the chamber often has a peculiar overlapping border at the base, extending out somewhat beyond the base of the chamber, both along the median line and also toward the umbilical ends. The peculiar arrangement of the pores in the last-formed chambers gives a striate appearance to the basal portion of those chambers.

\section{Elphidium evolutum (Chapman) Cushman}

Plate 18, figure 9

Polystomella striatopunctata (Fichtel and Moll) var. evoluta Chapman, Royal Soc. Victoria Proc., vol. 26, p. 173, pl. 16, fig. 9, 1913.

Test with the earlier whorls visible in the umbilical region, which is depressed; chambers about 10 in the adult coil, increasing slowly in size as added, later ones slightly inflated; sutures distinct, depressed, more so in later portion, with a few short retral processes, about 5 on each side in the adult chamber, the openings between rounded. Diameter $0.466 \mathrm{~mm}$.

Chapman described this as a variety of Polystomella striatopunctata, but it evidently is not related to that species. It came from borings in the Mallee, near Ouhen, County of Weeah, Victoria, Australia.

The evolute character of the test and the very rounded sutural openings suggest that this may be a forerunner of the genus Ozawaia.

\section{Elphidium bartletti Cushman}

Plate 18, figure 10

Elphidium bartletti Cushman, Smithsonian Misc. Coll., vol. 89, no. 9, p. 4, pl. 1, figs. 9a, b, 1933.

Test almost completely umbilicate but leaving a slight uncoiled portion at the umbilical area, periphery broadly rounded; chambers distinct, slightly inflated, especially in the later half of the last-formed coil, 10 to 12 or more in number; sutures distinct, usually depressed, occasionally with a slightly beaded appearance in the early portion, retral processes numerous and very short, often hardly visible; wall smooth, very finely perforate, polished; aperture formed by numerous small pores along the base of the apertural face of the chamber. Length $0.90 \mathrm{~mm}$; thickness $0.35 \mathrm{~mm}$. 
The types of this species were found off Labrador. Other stations are: Off camp Cape David Gray, Shannon Island, northeastern Greenland; 7 fathoms, near glacier, between Clavering Island and Homes Foreland, northeastern Greenland; near Shannon Island, northeastern Greenland; 10 to 35 fathoms, Shannon Island, northeastern Greenland; and Fox Basin, latitude $66^{\circ} 43^{\prime}$ $\mathrm{N}$. It resembles the young stages of $E$. arcticum but seems distinct. It will probably be found widely distributed in the general Arctic region.

\section{Elphidium translucens Natland ${ }^{23}$}

Plate 20, figures 7a, b

Elphidium translucens Natland, Scripps Inst. Oceanography Bull., Tech. ser., vol. 4, p. 144, pl. 5, figs. 3, 4, 1938.

Elphidium granulosum Natland [not Galloway and Wissler], Scripps Inst. Oceanography Bull., Tech. ser., vol. 3, line 28 (table), 1933.

Test compressed, periphery rounded, slightly lobulate, umbilical region roughened; proloculum is visible through small central umbo of clear shell material; chambers, twelve or thirteen in the last formed coil; sutures slightly curved, depressed, distinct, with small, elongate, narrow retral processes; walls translucent, vitreous, perforate, early coils visible through walls of outer coil; aperture composed of a row of small openings at the base of the last formed chamber.

Diameter $0.61 \mathrm{~mm}$; thickness $0.22 \mathrm{~mm}$.

Holotype (U. S. Nat. Mus. Cat. no. 22549). From locality 68 , lat. $33^{\circ} 20^{\prime} 49^{\prime \prime}$ N., long. $118^{\circ} 19^{\prime} 27^{\prime \prime}$ W. This locality is about 250 feet southeast of the Casino on the northwest side of Avalon Bay, Santa Catalina Island. Depth 9.7 meters. Bottom temp. $17^{\circ} 26$ C. November 15,$1931 ; 1: 45$ P. M.; salinity, $33.69 \mathrm{o} / \mathrm{oo}$; water usually very clear. Character of bottom: mostly composed of calcareous algae, Lithothamnion, with a small amount of mollusks and sand; foraminifera very abundant.

This beautiful species, $E$. translucens, was first thought to be E. granulosum (Galloway and Wissler), but was found to differ from the latter species by having much shorter chambers. It more closely resembles $E$. spinatum Cushman and Valentine, but is easily distinguished because its chambers are not ornamented with spines. $E$. translucens is essentially a shallowwater species living at depths of less than 30 meters. It has been observed in many samples off La Jolla and Long Beach, California.

\section{Elphidium tumidum Natland}

Plate 20, figures 8a, b

Elphidium tumidum Natland, Scripps Inst. Oceanography Bull., Tech. ser., vol. 4, p. 144, pl. 5, figs. 5, 6, 1938.

Elphidium hughesi Natland [not Cushman and Grant], Scripps Inst. Oceanography Bull., Tech. ser., vol. 3, line 5 (table), 1933.

Test somewhat depressed, periphery broadly rounded, lobulate, umbilical region depressed, roughened with minute papillae; chambers inflated, ten or eleven usially making up the last formed coil; sutures slightly curved, depressed, marked by rather indistinct, elongate, retral processes; walls rather finely perforate, vitreous, usually of light gray color with a slightly brownish tinge; aperture composed of several small openings at the base of the last chamber.

Diameter $0.50 \mathrm{~mm}$; thickness $0.22 \mathrm{~mm}$.

23 The description of Elphidium ezoense As zno, now on page 19 of this report, should have been inserted above, just preceding the description of Elphidium translucens Natland.
Holotype (U. S. Nat. Mus. Cat. no. 22550). From locality 68 , lat. $33^{\circ} 20^{\prime} 49^{\prime \prime}$ N., long. $118^{\circ} 19^{\prime} 27^{\prime \prime} \mathrm{W}$. This locality is about 250 feet southeast of the Casino on the northwest side of Avalon Bay, Santa Catalina Island. Depth 9.7 meters. Bottom temp. 17:26 C. November 15, 1931; 1:45 P. M.; salinity, 33.69 o/oo; water usually very clear. 'Character of bottom; mostly composed of calcareous algae, Lithothamnion, with a small amount of mollusks and sand; foraminifera very abundant.

This form was figured by Cushman and Valentine, but they did not give it a specific name. In my collection I have a large number of this form and the range of individual variation seems to be well outside that of its closest relative $E$. articulatum (d'Orbigny), which is a much thinner form. E. hughesi Cushman and Grant differs from this species by having more distinct and larger retral processes.

This inflated species is abundant at depths ranging from shore to 122 meters and has been found rare at a depth of 375 meters off Long Beach, California. It also occurs abundantly in the Pleistocene and rarely in the upper and lower Pliocene of southern California.

\section{Genus ELPHIDIELIA Cushman, 1936}

Elphidiella Cushman, Cushman Lab. Foram. Research Contr., vol. 12 , p. 89, 1936.

Elphidium (part) of authors.

Polystomella (part) of authors.

Genotype, Polystomella arctica Parker and Jones.

Test differing from Elphidium in having two rows of openings at the sutures and with a thickened area between, without definite retral processes. Pliocene to Recent.

The species of this genus are almost entirely Arctic and reach fairly large size.

\section{Elphidiella arctica (Parker and Jones) Cushman}

\section{Plate 18, figures 11-14}

Polystomella arctica Parker and Jones, in H. B. Brady, Linnean Soc. London Trans., Zoology, vol. 24, p. 471, pl. 48, fig. 18, 1864.

Dawson, Canadian Naturalist, vol. 5, p. 177, pl., fig. 8, 1870; Am. Jour. Sci., 3d ser., vol. 1, p. 206, fig. 8, 1871; Annals and Mag. Nat. History, ser. 4, vol. 7, p. 86, fig. 8, 1871.

H. B. Brady, Annals and Mag. Nat. History, ser. 5, vol. 1, p. 437 , pl. 21, figs. $13 a-d, 1878$; p. 415, 1881; Akad. Wiss. Wien Denkschr., vol. 43, p. 18, 1881; Challenger Rept., Zoology, vol. 9, p. 735, pl. 110, figs. 2-5, 1884.

Woodward, The Observer, vol. 4, p. 201, 1893.

Goës, K. svenska vetensk. akad. Handl., vol. 25, no. 9, p. 100, pl. 16, fig. 813, 1894.

Awerinzew, Acad. imp. sci. St.-Pétersbourg Mém., sér. 8, vol. 29 , no. 3 , p. $26,1911$.

Heron-Allen and Earland, Royal Irish Acad. Proc., vol. 31, pt. 64, p. 146, 1913.

Cushman, Rept. Canadian Arctic Exped., pt. M, p. 11, 1913.

Heron-Allen and Earland, Linnean Soc. London Trans., ser. 2, vol. 11, p. 283, 1916.

Cushman, Contr. Canadian Biology, p. 14, 1921 [1922].

?Koch, Schweizer. palaeont. Gesell. Ber., vol. 18, p. 357, 1923.

Polystomella crispa Linnaeus var. arctica Parker and Jones, Philos. Trans., vol. 155, p. 401, pl. 14, figs. 25-30, 1865.

Elphidium arcticum Cushman, U. S. Nat. Mus. Bull. 104, pt. 7, p. 27, pl. 11, figs. 1-6, 1930.

Blake, Biological survey of the Mount Desert region, pt. 5, p. 76, 1933. 
Cushman, Cushman Lab. Foram. Research Special Pub. 5, pl. 23, fig. 6, 1933.

Nonionina boueana Balkwill and Wright, Royal Irish Acad. Trans., vol. 28, Sci., p. 353, pl. 13, fig. 27, 1885.

Test of comparatively large size for the genus, compressed, periphery broadly rounded, margin only slightly lobulate, umbilical regions slightly depressed, smooth; chambers comparatively few, 10 to 12 in the last-formed coil, very slightly inflated; sutures distinct, slightly depressed, marked by a double row of rounded pores, no distinct retral processes; wall apparently sometimes double, often slightly rugose; aperture consisting of a row of small rounded pores at the base of the apertural face, with occasionally a second row slightly above it. Diameter $1.25 \mathrm{~mm}$; thickness $0.50 \mathrm{~mm}$.

The above-listed references give the records for the distribution of this species. The types came from the Shetland Islands. The species is known from the upper end of Buzzards Bay (possibly a new southern distribution due to the opening of the Cape Cod Canal) northward along the coast of New England; Gaspé Bay; Iceland; Norway southward to the west coast of Scotland; the Canadian Arctic; Hudson Bay; and the Siberian Arctic. It typically has a double row of pores along the sutures, like other Arctic species.

\section{Elphidiella hannai (Cushman and Grant) Cushman}

Plate 19, figures 1, 2

Elphidium hannai Cushman and Grant, San Diego Soc. Nat. History Trans., vol. 5, no. 6, p. 77, pl. 8, figs. 1, 2, 1927.

Cushman, Stewart, and Stewart, San Diego Soc. Nat. History Trans., vol. 6, p. 62, pl. 3, figs. 16, 17, 1930.

Test of medium size, the diameter about twice the thickness, periphery rounded but not broad, umbilical region flattened or very slightly concave, rarely slightly convex; chambers distinct, about 15 in the last-formed coil, not inflated; sutures very distinct, limbate, flush with the surface, with a line of very fine pores, sometimes irregularly doubled, continuing to the very center of the umbilical region, the sutures appearing as darker curved lines on the lighter mass of the thick but very finely perforate wall; aperture consisting of a series of very fine pores along the base of the apertural face and numerous others scattered irregularly all over the outer wall making up the apertural face. Diameter $1.00 \mathrm{~mm}$; thickness $0.50 \mathrm{~mm}$.

The types of this species were found at depths of 40 fathoms 15 miles south of the Farallon Islands, off California. The species also occurs in Monterey and is probably well distributed along the west coast of America. In the Pleistocene it occurs at Point Año Nuevo, San Mateo County, Calif. There are Pliocene records from a canyon about 2,165 feet north of the intersection of Kalorama and Poli Streets, city of Ventura, Ventura County; from Merced, San Mateo County, and below lighthouse at west end of Table
Bluff, elevation 40 feet, sec. 27 , 'T. 4 N., R. 2 W., Humboldt County, Calif.

The species is related to the Arctic forms in having a double row of openings along the sutures and very slightly developed retral processes.

\section{Elphidiella sibirica (Goës) Cushman}

Plate 19, figure 4

Polystomella sibirica Goës, K. svenska vetensk. akad. Handl., vol. 25, no. 9, p. 100, pl. 17, fig. 814, 1894.

Awerinzew, Acad. imp. sci. St.-Pétersbourg Mém., sér. 8, vol. 29, no. 3, p. 27, 1911.

Cushman, U. S. Nat. Mus. Bull. 71, pt. 4, p. 34, pl. 19, fig. $1,1914$.

Chapman, New Zealand Geol. Survey Paleont. Bull. 11, p. 89, pl. 17, fig. 14(?), 1926.

Hada, Sapporo Nat. History Soc. Trans., vol. 11, pt. 1, p. 14, 1929.

Elphidium sibiricum Cushman, U.S. Nat. Mus. Bull. 104, pt. 7, p. 29, pl. 11, figs. 7a, b, 1930.

Test of very large size for the genus, strongly compressed, periphery rounded, slightly lobulate, umbilical regions slightly depressed and the coils not completely involute, exposing some of the early coils in the central region; chambers numerous, as many as 25 in the lastformed coil, very slightly inflated; sutures distinct, very slightly depressed, marked by a single or double line of pores; wall smooth; aperture consisting of numerous small rounded pores in an inverted $V$-shaped arrangement. Diameter up to $4.00 \mathrm{~mm}$; thickness $0.30 \mathrm{~mm}$.

This species was originally described from shallow water of about 15 fathoms off Nova Zembla. I have had it from Bering Sea, and Awerinzew has had it from the Siberian Arctic. Chapman records it from the Miocene of New Zealand, but his figure does not show the characteristic double row of pores, and it is probably not identical.

\section{Elphidiella groenlandica (Cushman) Cushman}

\section{Plate 19, figure 3}

Elphidium groenlandicum Cushman, Smithsonian Mise. Coll., vol. 89, no. 9, p. 4, pl. 1, figs. 10a, b, 1933.

Test large, close-coiled, completely involute, the periphery subacute; chambers numerous, 15 or more in the final coil in the adult, of uniform shape throughout and increasing only slightly in size, the last chambers occasionally very slightly inflated; sutures distinct, very slightly if at all depressed, with a sigmoid curve and numerous retral processes, often 15 or more along a single suture; wall smooth, very finely perforate, polished, the umbilical region often with a clear area; aperture consisting of numerous pores along the base of the apertural face of the last-formed chamber. Diameter up to $1.00 \mathrm{~mm}$.

The types of this species were found off Bass Rock, northeastern Greenland.

This is a large, fine species, occurring only in the Bartlett collection from Greenland and not appearing 
in the collections from Fox Basin. It has occurred at numerous stations in or off northeastern Greenland and is often common as follows: Off Clavering Island, near glacier; 7 fathoms, Shannon Island; 7 fathoms, fiord between Clavering Island and Homes Foreland; off camp Cape David Gray, Shannon Island; 7 fathoms, near glacier between Clavering Island and Homes Foreland; near Shannon Island; 67 fathoms, off camp Cape David Gray, Shannon Island; Koldenian Sound; 7 fathoms, off Cape Stosch, Gotthaab Island, Hudson Land; and Wollaston Foreland, 5 miles off Cape Borlase Warren. It holds its characters very well throughout the different stations. This may possibly be the species referred by authors to Polystomella subnodosa from Arctic material.

Like several other Arctic species, $E$. groenlandica has double rows of pores along the sutures.

The following species were originally described as Polystomella and are not included under Elphidium or Elphidiella:

Polystomella planulata Lamarck, Histoire des animaux sans vertèbres, vol. 7, p. 625, 1822 (=?).

$P$. etrusca Defrance, Dictionnaire des sciences naturelles, vol. 32, p. 183,1824 (=?).

P. gaimardii D'Orbigny, Annales sci. nat., vol. 7, p. 284, no. 5, 1826 (=Peneroplis?).

P. umbilicata D'Orbigny, idem, p. 285, no. 9 (=?).

P. canariensis Reeve, Conchyliologie systématique, vol. 2, p. 291, pl. 297, fig. 7, 1842 (=Globigerina?).

P. vulgaris Reeve, idem, p. 291, pl. 297, fig. 8 (=Planorbulina?).

$P$. calcar Brown, Illustrated Recent Conchology of Great Britain, ed. 2, p. 1, pl. 1, figs. 1, 2, 1844 (=Robulus).

$P$. depressula Brown, idem, p. 1, pl. 1, fig. 3 (=Robulus).

$P$. burdigalensis D'Orbigny, Prodrome de paléontologie, vol. 3, p. 155 , no. 2885 , 1852 (=)?.

$P$. indigena Eichwald, Lethaea rossica, vol. 3, p. 4, pl. 1, figs. $2 \mathrm{a}-\mathrm{c}, 1853(=$ ?)

P. subaculeata Eichwald, idem, vol. 3, pl. 1, figs. 3a-c, 1855 (=?).

P. aequivoca Costa, Accad. pontaniana Atti, vol. 7, pt. 2, p. 221, pl. 19, figs. 11a, b, 1856 (=?)

P. granulata Costa, idem, p. 214, pl. 10, figs. 7a, A-C (=Elphidium sp.?).

P. ornata Costa, idem, p. 215 , pl. 10, fig. 8 ; pl. 19, figs. 12a-c (=Elphidium macellum?).

l'. striolata Costa, monstrosity, idem, pl. 19, figs. 15, 18 (=Elphidium macellum?).

P. quaterpunctata Abich, Acad. imp. sci. St.-Pétersbourg Mém., sér. 6 , vol. 7 , pl. 9, figs. $8 \mathrm{a}-\mathrm{h}, 1859$ (sections =?).

P. obscura Schwager, Palaeontographica, vol. 30, Pal. Theil, p. 138 , pl. 27 , pt. 4 , figs. $2 \mathrm{a}-\mathrm{c}, 1883$ (=?)

Genus OZAWaIA Cushman, 1931

Polystomella (part) Millett [not Lamarck], Royal Micr. Soc. Jour., p. 603, 1904.

Ozawaia Cushman, Cushman Lab. Foram. Research Contr., vol. 7, p. 80, 1931; U. S. Nat. Mus. Bull. 161, pt. 2, p. 53, 1933; Cushman Lab. Foram. Research Special Pub. 4, p. 193, 1933.

Genoholotype, Ozawaia tongaensis Cushman.

Test free, in the early stages planispiral, compressed, later uncoiling and becoming circular in transverse section, bilaterally symmetrical; sutures marked by retral processes both in the early stages and in the adult, wall calcareous, finely perforate; aperture in the early stages made up of numerous pores at the base of the apertural face, in the adult a series of rounded pores in the terminal face in the last-formed chamber. Recent.

This genus, so far as known, is confined to shallow water of the Pacific. It should be looked for, however, in the general Indo-Pacific region and in the late Tertiary of the same region.

It is an end form developing an uncoiled adult from a coiled early stage, similar to developments seen in many other families of the Foraminifera.

\section{Ozawaia tongaensis Cushman}

Plate 19, figures 5-8

Polystomella crispa Millett [not Linné], Royal Micr. Soc. Jour., p. 603, pl. 11, fig. 2, 1904.

Ozawaia tongaensis Cushman, Cushman Lab. Foram. Research Contr., vol. 7, p. 80, pl. 10, figs. 7-10, 1931; U. S. Nat. Mus. Bull. 161, pt. 2, p. 53, pl. 12, figs. 10-12, 1933; Cushman Lab. Foram. Research Special Pub. 5, pl. 23, figs. 9, 10, 1933 .

Test in the early stages close-coiled, almost completely involute, somewhat keeled and with a distinct boss in the umbilical region; chambers distinct, inflated, in the early portion much compressed, in the uncoiled portion almost circular in transverse section; sutures distinct, depressed, rather strongly curved, retral processes short but numerous and distinct; aperture in the coiled portion at the base of the apertural face, later becoming numerous rounded pores in the terminal face of the chamber in the uncoiled portion. Length up to 0.6 $\mathrm{mm}$; breadth $0.35 \mathrm{~mm}$; thickness $0.15 \mathrm{~mm}$.

This is evidently the same species that Millett figured from the Malay Archipelago in the reference cited above. It is very abundant at Vavau Anchorage, Tonga Islands, from which it was originally described. Specimens less well developed but having the characteristic early stages and showing slight tendencies of becoming uniserial were found at Viva Anchorage in 3 fathoms and at Rotonga in 7 fathoms.

This species is unique, although from the records it is probably to be looked for as widely distributed in the Indo-Pacific region in shallow water. It represents the only attempt of this group, represented typically by Elphidium, to assume an uncoiled form and is evidently a very recent development in the history of this family.

\section{Genus FAUJASINA D'Orbigny, 1839}

Faujasina D'Orbigny, in De la Sagra, Historia física, política y natural de la isla de Cuba, Foraminifères, p. 109, 1839; Foraminifères fossiles $\mathrm{du}$ bassin tertiaire de Vienne, $\mathrm{p}$. 193, 1846.

Millett, Royal Geol. Soc. Cornwall Trans., vol. 12, pt. 3, p. 3, 1898; pt. 8, p. 719, 1902.

Cushman, Cushman Lab. Foram. Research Contr., vol. 3, p. 51, 1927; Cushman Lab. Foram. Research Special 
Pub. 1, p. 208, 1928; U. S. Nat. Mus. Bull. 104, pt. 7, p. 29, 1930; Cushman Lab. Foram. Research Special Pub. 4, p. 194, 1933.

Genoholotype, Faujasina carinata D'Orbigny.

Test similar to Elphidium but trochoid, planoconvex, the dorsal side flattened and showing the earlier whorls, ventral side convex, involute.

The genotype is from the upper chalk of Maestricht, Holland, according to D'Orbigny. I have been. unable to find anything like this form in the Maestricht material I have examined. The genus is a specialized one, and as Elphidium itself did not appear until the simple forms of the Eocene, it is very evident that there is some error in regard to it. There are excellent specimens of Faujasina from the Pliocene of St. Ertb, Cornwall, England, as will be noted.

\section{Faujasina carinata D'Orbigny}

Plate 19, figure 10

Faujasina carinata D'Orbigny, Foraminifères fossiles du bassin tertiaire de Vienne, p. 194, pl. 21, figs. 29-31, 1846.

Millett, Royal Geol. Soc. Cornwall Trans., vol. 12, pt. 8, p. 719, 1902.

Heron-Allen and Earland, Royal Micr. Soc. Jour., 1916, pl. 9 , figs. $6-8$.

Cushman, Cushman Lab. Foram. Research Special Pub. 4, pl. 19, figs. 4a-c, 1933; Special Pub. 5, pl. 23, figs. $8 \mathrm{a}-\mathrm{c}, 1933$.

Copies of D'Orbigny's figures of this species from the Vienna Basin monograph are given on plate 19. The types are said to have come from the Upper Cretaceous Senonian of Maestricht, Holland. I have been unable to find any such form in the material I have examined from this locality, nor does it appear in the literature on the Maestricht material that has been published since D'Orbigny's time. Millett records the species from Pliocene beds of St. Erth, Cornwall, England. I have a slide of this species received from Millett many years ago with very typical specimens. A few years ago I purchased from Ward's Natural Science Establishment, Rochester, N. Y., several small bottles of material of a collection which it had purchased from a dealer in Paris. One of these, supposed to be from the "Devonian of Cornwall", proved to be undoubtedly from St. Erth and contained many specimens of $F$. carinata. D'Orbigny. The other species with it are evidentl: $:$ of late Tertiary age. There is some question as to the source of the St. Erth material, and it is possible that by some strange error D'Orbigny may have had some of this material and it may have been wrongly labeled. Only some such occurrence would seem to explain this strange discrepancy.

The species was recorded by Costa from the late Tertiary of Italy, but Fornasini has shown that none of Costa's material is really Faujasina. The knowledge of the species must therefore rest on D'Orbigny's figure, description, and supposed locality and the actual material from St. Erth.
Heron-Allen and Earland figure a broken specimen under this name in their paper on Foraminifera off South Cornwall cited above. This may be a fossil specimen derived from the St. Erth material.

\section{Faujasina ? orbignyi Terquem}

Plate 19, figure 9

Faujasina orbignyi Terquem, Soc. géol. France Mém., sér. 3, vol. 2, p. 49, pl. 2 (10), figs. 28a-c, 1882.

Copies of Terquem's figures are given on plate 19 . The species is recorded from the middle Eocene of the Paris Basin, at Vaudancourt and Septeuil, as very rare. I have failed to find any specimens in the Vaudancourt material I have examined. It is very difficult to make out from Terquem's figures which are usually not accurate, just where this form should be placed.

Genus Polystomellina Yabe and Hanzawa, 1923

Polystomellina Yabe and Hanzawa, Japanese Jour. Geology and Geography, vol. 2, p. 99, 1923.

Cushman, Cushman Lab. Foram. Research Contr., vol. 3, p. 51, 1927; Cushman Lab. Foram. Research Special Pub. 1, p. 208, 1928; Special Pub. 4, p. 194, 1933.

Genoholotype, Polystomella (Polystomellina) discorbinoides Yabe and Hanzawa.

Test similar to Elphidium in general structure but trochoid, planoconvex, ventral side flattened and involute, dorsal side convex, showing the earlier whorls; aperture on the periphery and extending to the ventral side.

This genus, so far as known, is confined to the IndoPacific region, developing in the Miocene of Australia and Japan and possibly still living in the Indo-Pacific.

\section{Polystomellina discorbinoides Yabe and Hanzawa}

Plate 19, figures 11, 12

Polystomella (Polystomellina) discorbinoides Yabe and Hanzawa, Japanese Jour. Geology and Geography, vol. 2, p. 99, text figs. a-d, 1923.

Cushman, Cushman Lab. Foram. Research Special Pub. 4, pl. 19, figs. 6a-c, 1933; Special Pub. 5, pl. 23, figs. 7a-c, 1933.

Test trochoid, planoconvex, dorsal side with a somewhat raised spire showing the earlier whorls, ventral side flattened, completely involute, periphery subacute, slightly keeled; chambers distinct, not inflated, increasing rather rapidly in size in the final whorl; sutures distinct, slightly curved, not depressed, retral processes short, especially so in the adult, as many as 12 to 15 in the adult chamber on the ventral side, only slightly fewer on the dorsal side; wall generally smooth except for the retral processes; aperture at the periphery end extending slightly to the ventral side.

The species is known from the Natsukawa limestone of the Neogene Tertiary of Kutta, Santo-gori, Province of Echigo, Japan. 
Polystomellina miocenica Cushman

Plate 19, figure 13

Polystomellina miocenica Cushman, Cushman Lab. Foram. Research Contr., vol. 12, p. 87, pl. 15, figs. 8a-c, 1936.

Test trochoid, nearly equally biconvex, dorsal side showing all the coils, ventral side completely involute, periphery subacute, slightly keeled; chambers distinct except the earlier ones of the dorsal side, which are obscured by a growth of secondary shell material forming an umbonate mass, of rather uniform size and shape, outer edge slightly raised; sutures fairly distinct, slightly depressed, curved, becoming slightly sigmoid on the ventral side, retral processes distinct, 5 or 6 on the dorsal side and 8 or 9 on the ventral side in the adult chamber, somewhat oblique; wall strongly reticulate, umbilical region with a distinct umbo; aperture a low opening at the base of the apertural face, slightly extended to the ventral side. Diameter $1.00 \mathrm{~mm}$ or more; thickness $0.40 \mathrm{~mm}$.

The types of this species came from the Miocene Filter Quarries, Batesford, Victoria, Australia.

This species differs from $P$. discorbinoides Yabe and Hanzawa in the sharper periphery, oblique retral processes, strongly umbonate umbilicol region, and secondary shell material of the central part of the dorsal side.

\section{Polystomellina australis Cushman}

Plate 19, figure 14

Polystomellina australis Cushman, Cushman Lab. Foram. Research Contr., vol. 12, p. 87, pl. 15, figs. 7a-c, 1936.

Test trochoid, dorsal side with early coils visible, ventrally completely involute, spire much depressed, flattened, ventral side slightly convex, umbilicus slightly depressed, periphery rounded but with a narrow keel; chambers distinct, about 12 in the adult coil, of uniform shape, increasing very gradually in size as adcied, the outer edge raised, with a distinct ridge; sutures slightly depressed, retral processes few, about 5 on the dorsal and 6 on the ventral side in the adult chamber, nearly as long as the chamber breadth, slightly oblique to the sutures; aperture a low opening at the peripheral margin and extending slightly to the ventral side. Diameter $0.50 \mathrm{~mm}$; thickness $0.20 \mathrm{~mm}$.

The types of this species came from dredgings in 10 fathoms, Van Diemans Inlet, Gulf of Carpentaria, Queensland, Australia.

This species differs from $P$. discorbinoides Yabe and Hanzawa in the lower spire, less distinct keel, fewer chambers, and coarser and more oblique retral processes.

NoтE.-While this paper was in page proof several new species and varieties belonging to the Nonionidae were published by R. M. Kleinpell in Miocene stratigraphy of California, 1938, as follows: Nonion goüdkoffi Kleinpell, n. sp., p. 231, pl. 20, figs. 2, 5; Nonion incisum (Cushman) var. kernensis Kleinpell, n. var., p. 232; Nonion schencki Kleinpell, n. sp., p. 235, pl. 16, figs. 11a, b; Nonion ynezianum Kleinpell, n. sp., p. 237, pl. 2, figs. 1, 2; Elphidium granti Kleinpell, n. sp., p. 238, pl. 19, figs. $1,11$. 


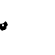




\section{PLATES 1-20}




\section{PLATE 1}

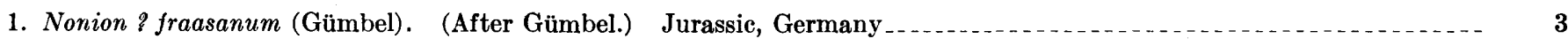

2. N. ? nodulosum (Terquem). (After Terquem.) Jurassic, France

3. $N$. ? subangulosum (Terquem). (After Terquem.) Jurassic, France $\ldots \ldots$

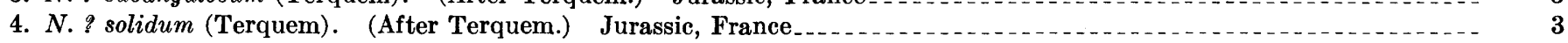

5. N. jarvisi Thalmann. Cretaceous, Trinidad, $\times 45$. Holotype

6. 7. N. laeve (D'Orbigny). 6, Photograph of D'Orbigny's model. 7, Eocene, France, $\times 55 . \quad$ Topotype 5

8. N. rugosum (D’Orbigny). (After Fornasini.) Eocene, France

9-11. N. graniferum (Terquem). 9, 10, after Terquem. 11, Eocene, France, $\times 75$

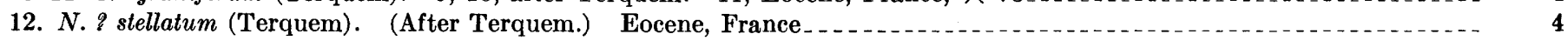

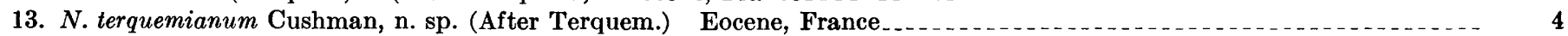

14. N. latescens (Schwager). (After Schwager.) Eocene, Egypt

15. N. planatum Cushman and Thomas. Eocene, Claiborne, Texas, $\times 75$. Holotype...

16. N. wilcoxense Cushman and Ponton. Eocene, Wilcox, Alabama, $X 90$. Holotype

17, 18. N. florinense Cole. Eocene, Guayabal, Mexico, X 90. Topotypes

19. N. danvillense Howe and Wallace. Eocene, Jackson, Louisiana, $X 90$. Topotype

20-22. N. micrum Cole. Upper Eocene, Chapapote, Mexico, $X$ 65. Topotypes

23, 24. N. mexicanum Cole. Eocene, Guayabal, Mexico, X 115. Topotypes

25. N. bonairense Pijpers. (After Pijpers.) Upper Eocene, Bonaire. $a, b$, Opposite sides; $c$, apertural view $\ldots . . . . . .$.

26. N. hummelincki Pijpers. (After Pijpers.) Upper Eocene, Bonaire. $a, b$, Opposite sides; $c$, apertural view..-----

27. N. whitsettense (Cushman and Applin). Upper Eocene, Texas, $X$ 65. Holotype

28. N. samanicum (W. Berry). (After Berry.) Upper Eocene, Lobitos, Peru, $\times$ 55. $a, b$, Opposite sides; $c$, apertural view -29, 30. N. olssoni (W. Berry). 29, after Berry. Upper Eocene, Lobitos, Peru, $\times 55$. $a, b$, Opposite sides; $c$, apertural view. $30 a, b$, Chapapote, Mexico, $\times 90$ 


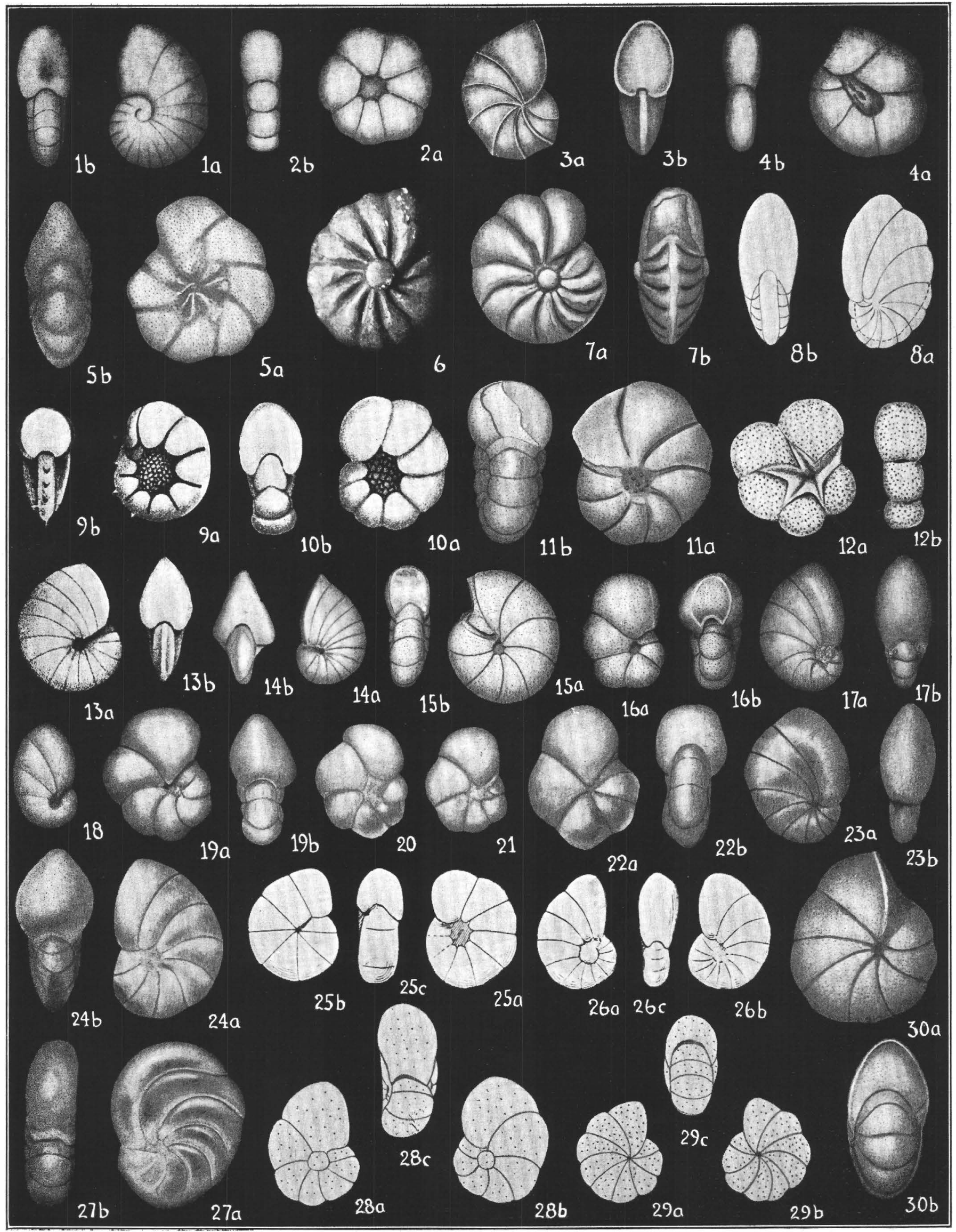

THE FORAMINIFERAL FAMILY NONIONIDAE. 


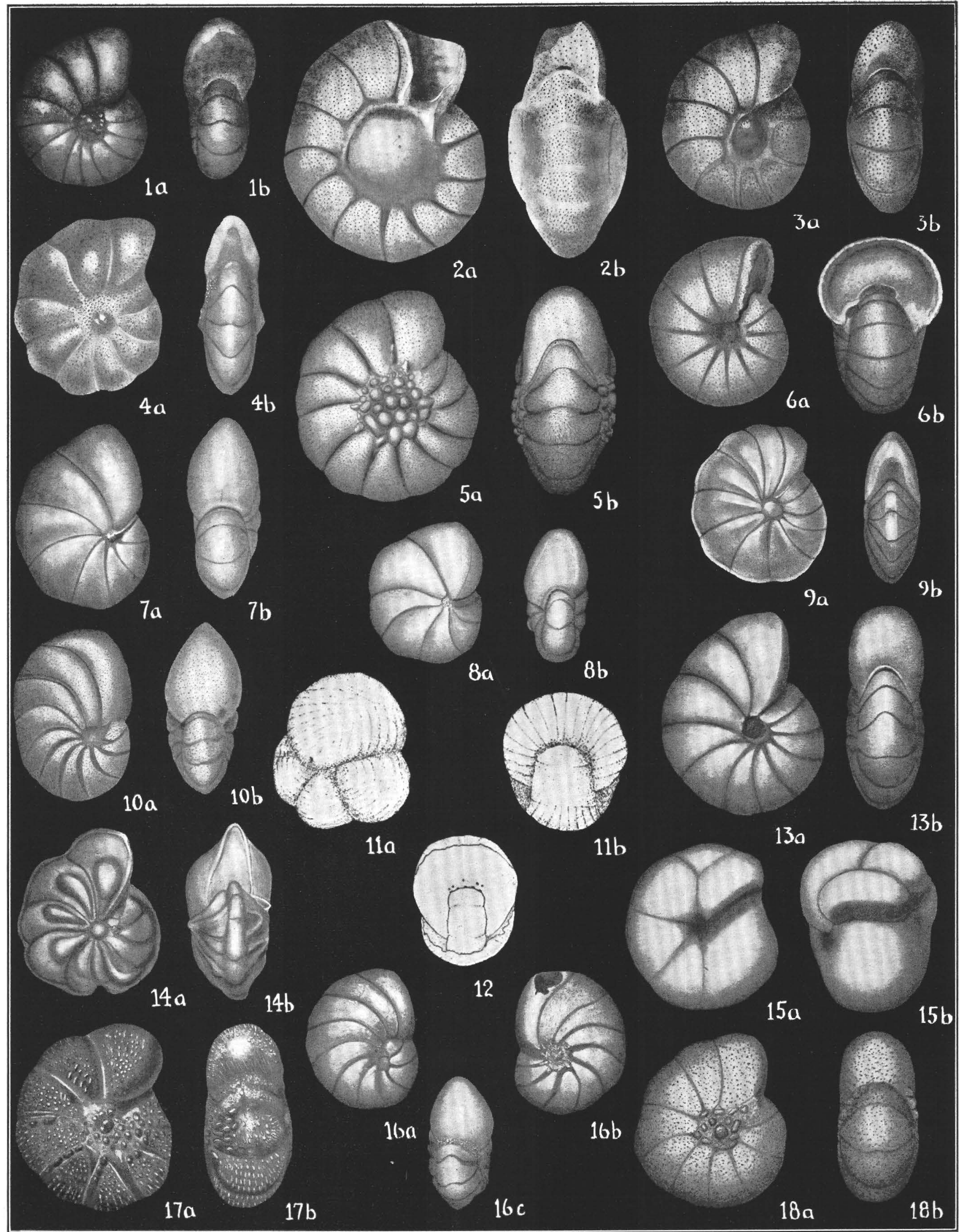

THE FORAMINIFERAL FAMILY NONIONIDAE. 


\section{PLATE 2}

[Unless otherwise designated: a, side view; b, apertural view]

1-3. Nonion chapapotense Cole. 1, Upper Eocene, Chapapote, Mexico, $\times$ 55. Topotype. 2, 3, Upper Eocene, Mississippi, X $115 \ldots$

4. N. inexcavatum (Cushman and Applin). Upper Eocene, Texas, $\times 90$. Holotype

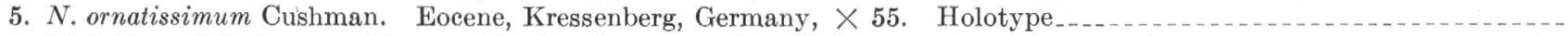

6. N. halkyardi Cushman. Eocene, Biarritz, France, $\times 90$. Holotype

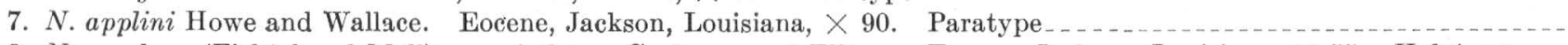

8. N. scaphum (Fichtel and Moll), var. inflatum Cushman and Ellisor. Eocene, Jackson, Louisiana, $\times 55$. Holotype ...-

9. N. laeve (D’Orbigny) var. marginatum Cushman and Ellisor. Eocene, Jackson, Texas, $\times 65$. Holotype .............

10. N. mesonense Cole and Gillespie, Oligocene, Mexico, $\times 90$. Topotype

11, 12. Nonion? marielense Palmer. (After Palmer.) $\times 75.12$, Broken specimen showing porous aperture

13. Nonion affine (Reuss). Oligocene, Hermsdorf, Germany, $\times 90$. Topotype

14. N. turgescens Cushman. Oligocene, Germany, $\times 105$. Holotype

15. N. anomalinum (Cushman). Oligocene, Panama Canal Zone, $X 45$. Holotype

16. N. mesonense Cole and Gillespie. Oligocene, Mexico, $\times 65$. $a, b$, Opposite sides; $c$, apertural view ..............

17, 18. N. granosum (D'Orbigny). Miocene, Nussdorf, near Vienna, $\times 65$. Topotypes 


\section{PLATE 3}

[In all figures: $a$, side view; $b$, apertural view]

1. Nonion roemeri Cushman. Oligocene, Germany, $\times 90$. Holotype

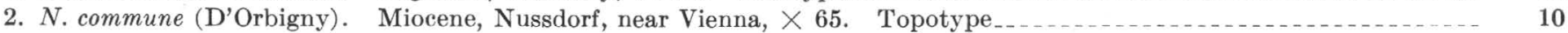

3. N. perforatum (D’Orbigny). Miocene, Nussdorf, near Vienna, $X 65$. Topotype

4-6. N. elongatum (D’Orbigny). 4, 6, Miocene, Dax, France, X 45. Topotypes. 5, after Fornasini, D’Orbigny, 1826 -- $\quad 11$

7, 8. N. boueanum (D'Orbigny). Miocene, Nussdorf, near Vienna. 7, X 45; 8, X 65. Topotypes $\ldots . . . . .$.

9. N. lamarcki (D’Orbigny). Miocene, Bordelais, Salles, France, $\times 55 \ldots 11$

10, 11. N. soldanii (D'Orbigny). Miocene, Nussdorf, near Vienna, 10, X 65; 11, X 55. Topotypes..............

12. N. tuberculatum (D’Orbigny). Miocene, Nussdorf, near Vienna, $\times 90$. Topotype...................... 13

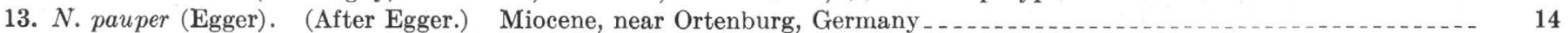

14. N. glabrellum Cushman. Miocene, Florida, $X 90$. Holotype

15. N. dense-punctatum (Egger). Miocene, Ortenburg, Germany, X 115, Topotype ...........................

16, 17. N. tuberculatum (D'Orbigny). Miocene, Ortenburg ("N. subgranosa Egger"), X 115. Topotypes.......... 13

18. N. stachei Cushman. Miocene, New Zealand, $X 45$. Holotype

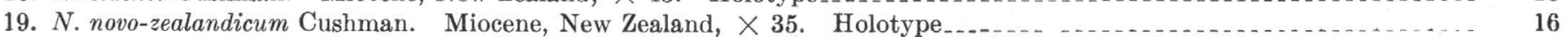




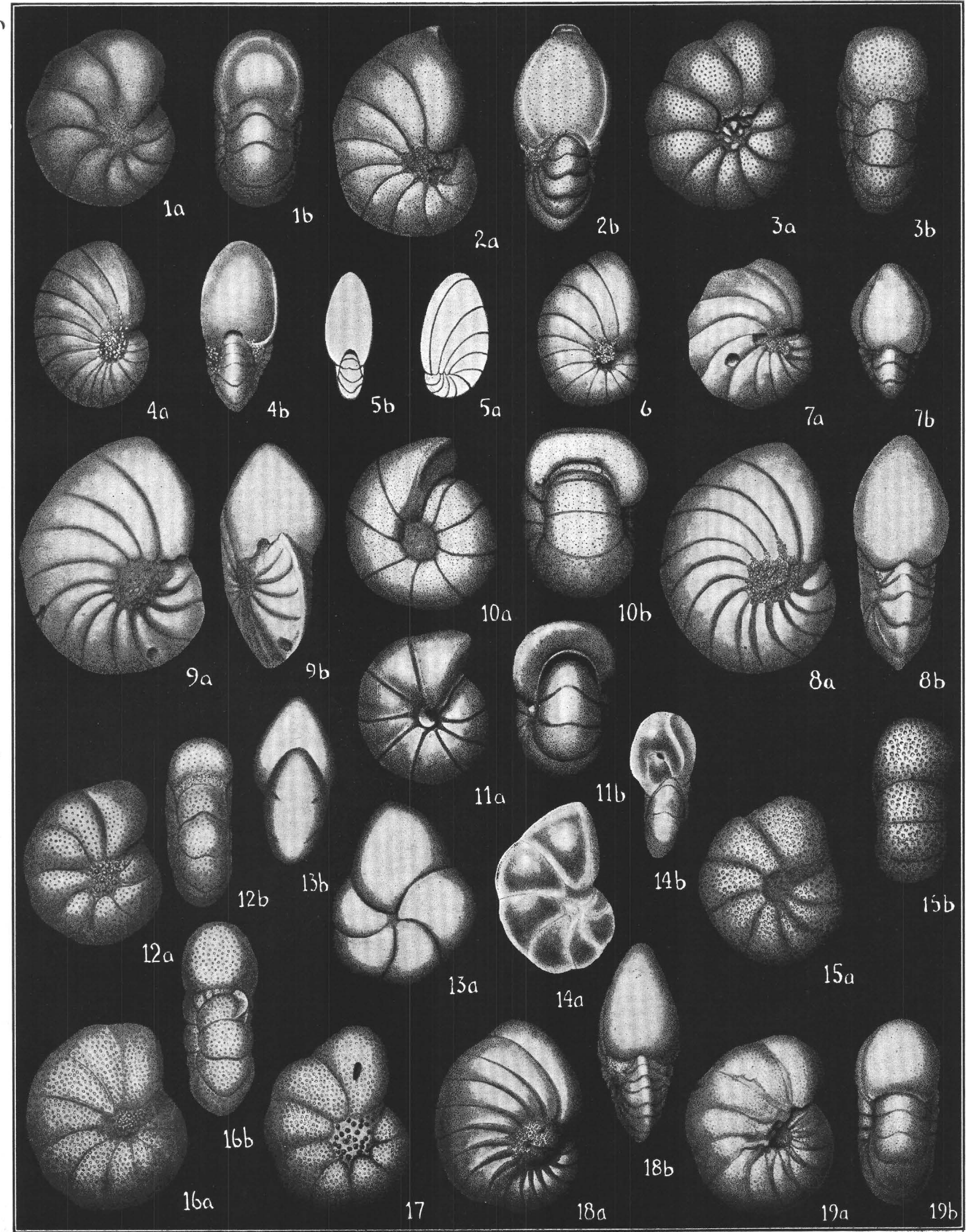




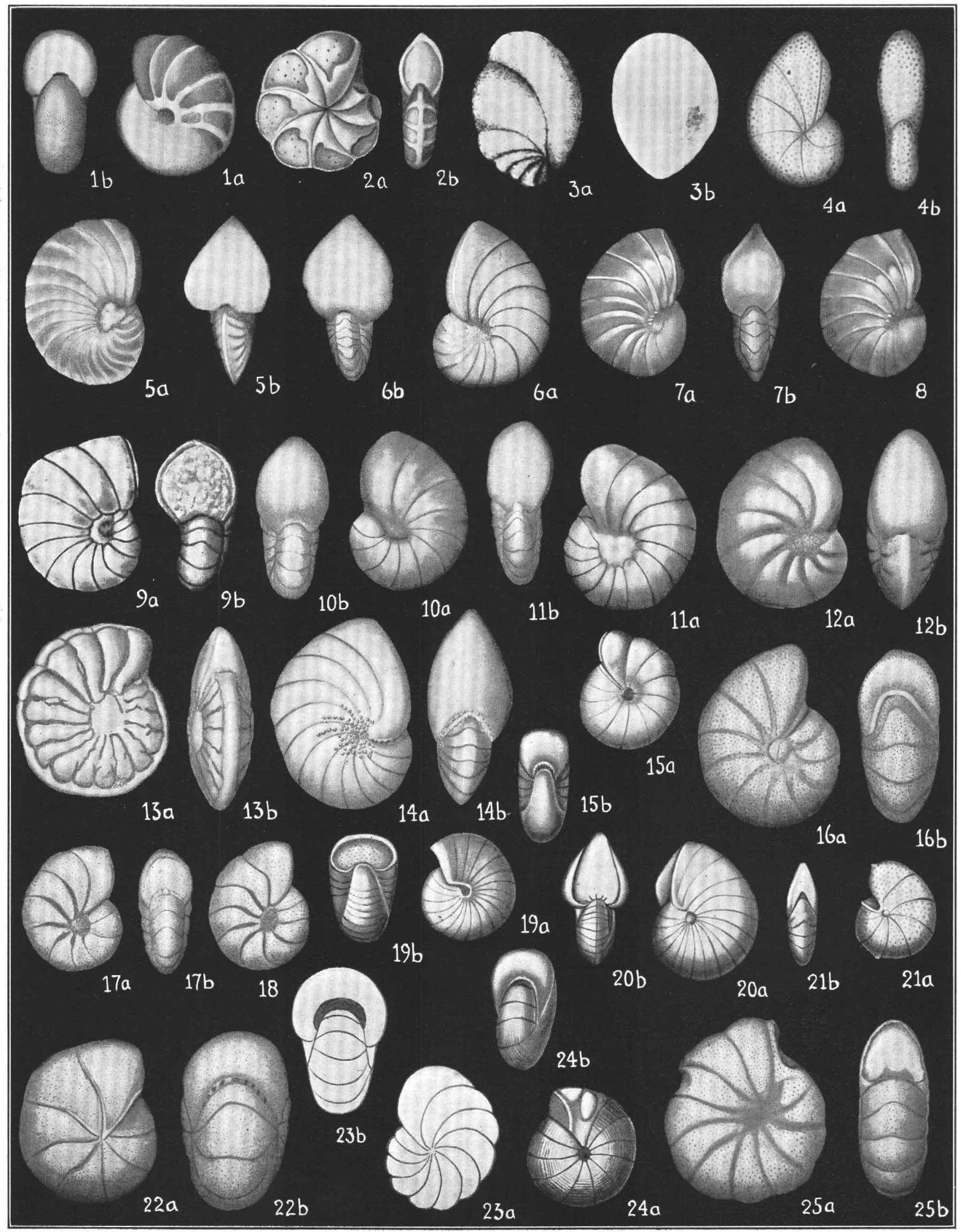

THE FORAMINIFERAL FAMILY NONIONIDAE. 


\section{PLATE 4}

[In all figures: $a$, side view; $b$, apertural view]

2. N leo (Karrer) (After Karer) Mealand.-.

3. N. inflatum (Schubert). (After Schubert.) Miocene, Central Europe $\ldots$

4. N. extensum (Cushman). Miocene, South Carolina, $\times 50$. Holotype

5. N. costiferum (Cushman). Miocene, California, $X$ 40. Holotype

6. N. incisum (Cushman). Miocene, California, $\times 65$. Holotype

7, 8. N. medio-costatum (Cushman). Miocene, California, X 45. 7, Holotype; 8, paratype

9. N. montereyanum Cushman and Galliher. Miocene, California, $\ 55$. Holotype $\ldots$

10. N. montereyanum Cushman and Galliher var. carmeloense Cushman and Galliher. Miocene, California, $\times 65$. Holotype _.

11. N. pizarrense W. Berry var. multicameratum Cushman and Kleinpell. Miocene, California, $\times 55$. Holotype

12. N. dingdeni Cushman. Miocene, Dingden, Germany, $\times 45$. Holotype

13. N. dollfusi Cushman. Miocene, France, $\times 30$. Holotype

14. N. victoriense Cushman. Pliocene, Australia, $\times 55$. Holotype

15. N. polystoma (Costa). (After Costa.) Pliocene, Italy

16. N. nicobarense Cushman. Pliocene, Kar Nicobar, $\times 90$. Holotype

17, 18. N. ibericum Cushman. Pliocene, Malaga, Spain, $X 115$. Holotype

19. N. attenuatum (Costa). (After Costa:) Pliocene, Italy

20. N. nautiloideum (Costa), (After Costa.) Pliocene, Italy

21. N. rude (Costa), (After Costa.) Pliocene, Italy

22. N. schwageri Cushman. Pliocene, Kar Nicobar, $\times 115$. Holotype

23. N. soldanii (D'Orbigny). (After Fornasini, "N. molo D'Orbigny.") Pliocene, Italy

24. N. striolatum (Costa). (After Costa.) Pliocene, Italy

25. N. angustum Cushman. Pliocene, Lanarka, Cyprus, $\ 65$. Holotype 


\section{PLATE 5}

[Unless otherwise designated; a, side view; b, apertural view]

betridgense Barbat and Johnson. (After Barbat and Johnson.) Miocene, California, $\times 60$

2. N. buxovillanum (Andreae). (After Andreae.) Oligocene, Germany $\ldots \ldots \ldots$

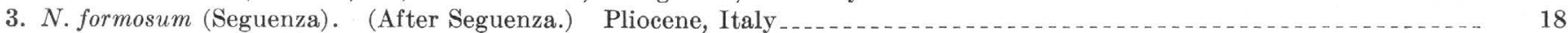

4. N. subcarinatum (Seguenza). (After Seguenza.) Pliocene, Italy

5. N. ? excavatum (Seguenza). (After Seguenza.) Pleistocene, Italy

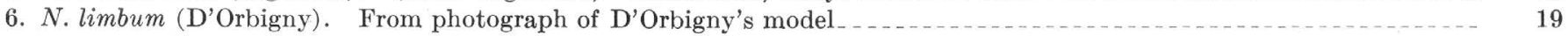

7. N. galeatum Cutshman. Pliocene, Fiji, X 55. Paratype $\ldots \ldots \ldots$

8. N.? perfossum (Clodius). (After Clodius) $\ldots \ldots \ldots$

9-12. N. pompilioides (Fichtel and Moll). 9, After Fichtel and Moll; 10, from photograph of D'Orbigny's 1826 model "N. umbilicatula D'Orbigny"; 11, east coast of United States, $\times 90 ; 12$, from west of Iceland, $\times 65 \ldots . . . . .$.

13. N. incrassatum (Fichtel and Moll). (After Fichtel and Moll) 14-17. N. asterizans (Fichtel and Moll). 14, Pliocene, Castel Arquato, Italy, X 40; 15, after Fichtel and Moll, Recent, Mediterranean, $a, b$, opposite sides; $c$, apertural view; 16, after Goës; 17, Recent, Rimini, Italy ..............-

18-21. N. scapha (Fichtel and Moll). 18, After Fichtel and Moll; 19, after H. B. Brady; 20, after Fichtel and Moll's

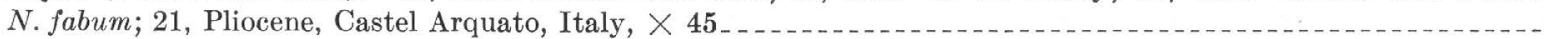

22-25. $N$. depressulum (Walker and Jacob). 22, After Walker and Jacob, $a, b$, opposite sides; 23-25, after Heron-Allen and Earland, west of Scotland, $\times 65$

26. N. depressulum (Walker and Jacob) var. matagordanum Kornfeld. (After Kornfeld.) Recent, Gulf of Mexico. $\times 80$.

27. N. ? umbilicatulum (Walker and Jacob). (After Walker and Jacob.) $a, b$, Opposite sides ...................

28. N. elypticum (D'Orbigny). (After Fornasini, D’Orbigny, 1826.) Recent, Madagascar.....................

29. N. ? crassulum (Walker and Jacob). (After Walker and Jacob.) $a, b$, Opposite sides......................

30. N. politum (D'Orbigny). (After Fornasini, D’Orbigny, 1826.) Recent, Rimini, Italy ........................

31, 32. N. germanicum (Ehrenberg). 31, After Williamson; 32, Bognor, Sussex, England, $\times 100 \ldots \ldots$ 


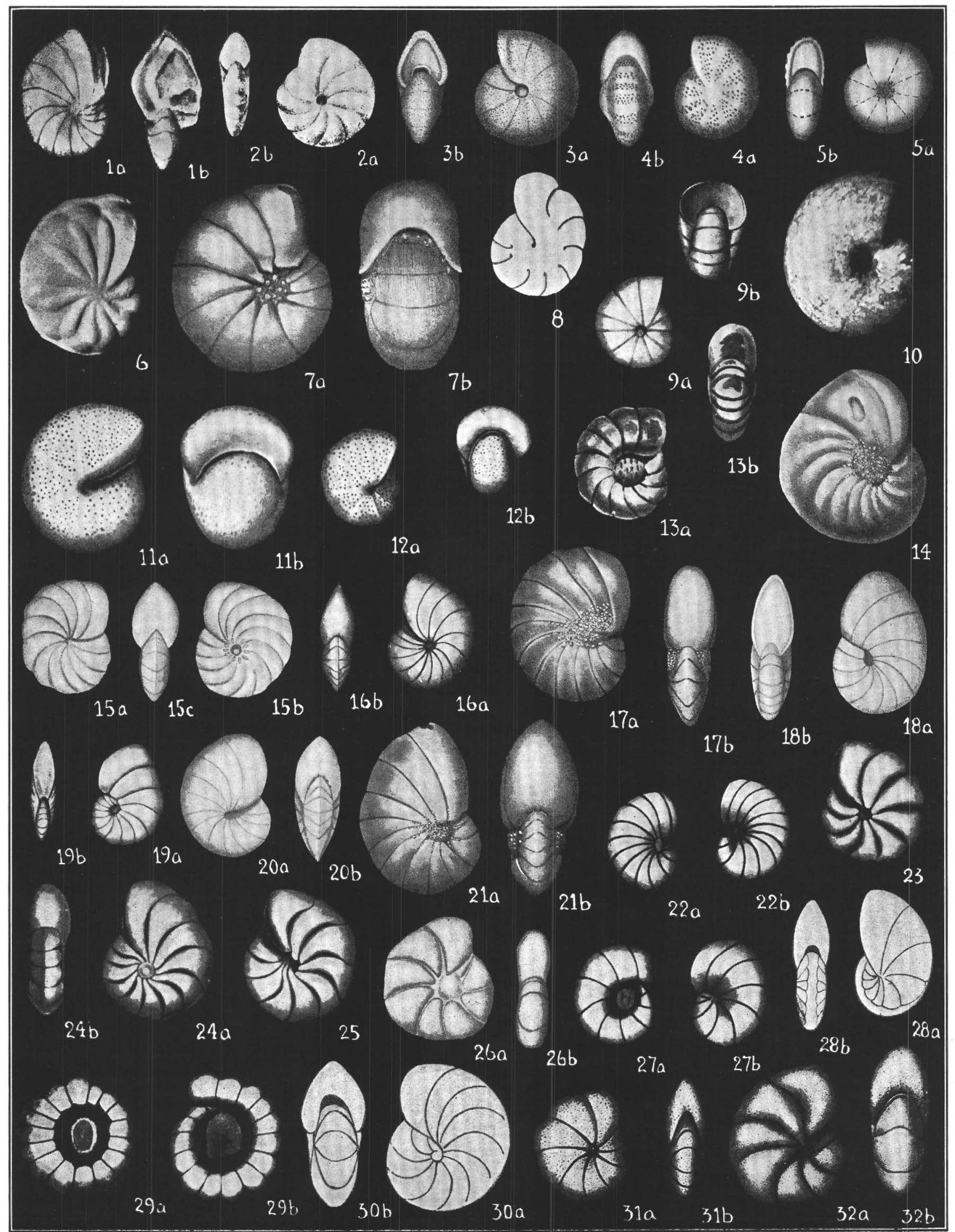




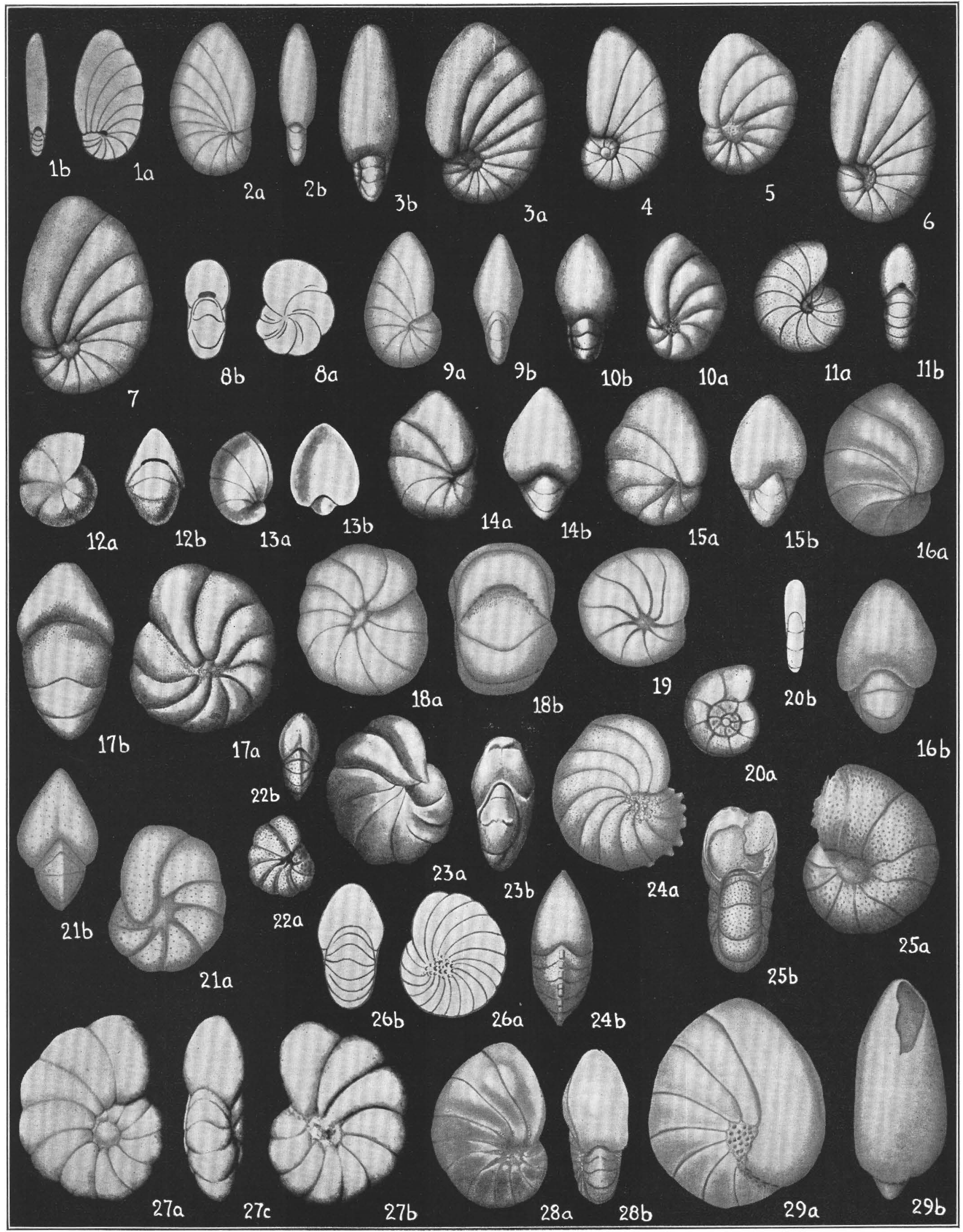

THE FORAMINIFERAL FAMILY NONIONIDAE. 


\section{PLATE 6}

1-7. Nonion grateloupi (D’Orbigny). 1, After Fornasini, D’Orbigny, 1826, Miocene, Dax, France; 2, after D’Orbigny, 1839, Recent, Cuba; $3-7$, from Dry Tortugas, Florida, $\times 90$

8. N. laevigatum (D'Orbigny). (After Fornasini, D'Orbigny, 1826.) Recent, Rimini, Italy

9, 10. N. sloanii (D'Orbigny). 9, After D'Orbigny, 1839, Recent, Cuba; 10, San Juan Harbor, Puerto Rico, X $90 \ldots$

11. N. barleeanum (Williamson). (After Williamson)

12. N. subcarinatum (D'Orbigny). (After D'Orbigny, 1839)

13-16. N. labradoricum (Dawson). 13, After Dawson; 14, Gaspé Bay, $\times 55$; 15, Casco Bay, Maine, $\times 55$. 16, Albatross $\mathrm{D} 2078, \times 55$

17-19. N. orbiculare (H. B. Brady). 17, Hudson Bay, $\times 65 ; 18,19$, after H. B. Brady, $\times 45$ 20. N.? exponens (H. B. Brady, Parker, and Jones). (After H. B. Brady, Parker and Jones.) Recent, Abrolhos Bank..-.21-23. N. pauperatum (Balkwill and Wright). 21, After Balkwill and Wright, coast of Ireland, $\times 115 ; 22$, after Heron-Allen and Earland, off island of Jersey; 23, after Heron-Allen and Earland, off Selsey, England . .................

24. N. boueanum (D'Orbigny) var. armatum (H. B. Brady). (After H. B. Brady.) $\times 45 \ldots$

25. N. pacificum (Cushman). Recent, Samoa. X 65. Holotype

26. N. lamarcki (D’Orbigny). (After Fornasini, D’Orbigny, 1839.) Miocene, Dax, France

27. N. pizarrense W. Berry, Miocene, Florida. $\times 65 . \quad a, b$, Opposite sides; $c$, apertural view

28. N. pizarrense W. Berry var. basispinatum Cushman and Moyer. Recent, off San Pedro, Calif. $\times 45$. Holotype_..-

29. N. subturgidum (Cushman). Recent, Samoa, $\times 65$. Holotype.

Page

21

22

22

23

23

23

23 


\section{PLATE 7}

[Unless otherwise designated: $a$, dorsal view; $b$, ventral view; $c$, apertural view]

1, 2. Nonionella austinana Cushman. Crotaceous, Texas. $\times 150$

3. N. robusta Plummer. Cretaceous, Texas. $\times 95 \ldots$

4. N. warburgi Brotzen. (After Brotzen.) $\times 75 . \quad a$, Dorsal view; $b$, ventral view; $c$, peripheral view _............. 28

5. N. cretacea Cushman. Cretaceous, Tennessee. $\times 150$. Holotype

6. N. reussana Cushman, n. sp. Cretaceous, Germany, $\times 90$. Holotype

7. N. extensa Brotzen. (After Brotzen.) $\times$ 75. $a$, Dorsal view; $b$, ventral view; $c$, peripheral view

8. N. gardnerae Cushman. Eocene, Claiborne, Texas. $\times 90$. Holotype

9-11. N. cockfieldensis Cushman and Ellisor. Eocene, Claiborne, Texas. $\times 90.9$, Holotype: $a$, dorsal view; $b$, apertural view. $10 a$, Ventral view; $b$, apertural view _.

12. N. alabamensis Cushman and Ponton. Eocene, Wilcox, Alabama. $\times 65$. Holotype

13. N. wilcoxensis Cushman and Ponton. Eocene, Wilcox, Alabama. × 75. Holotype 


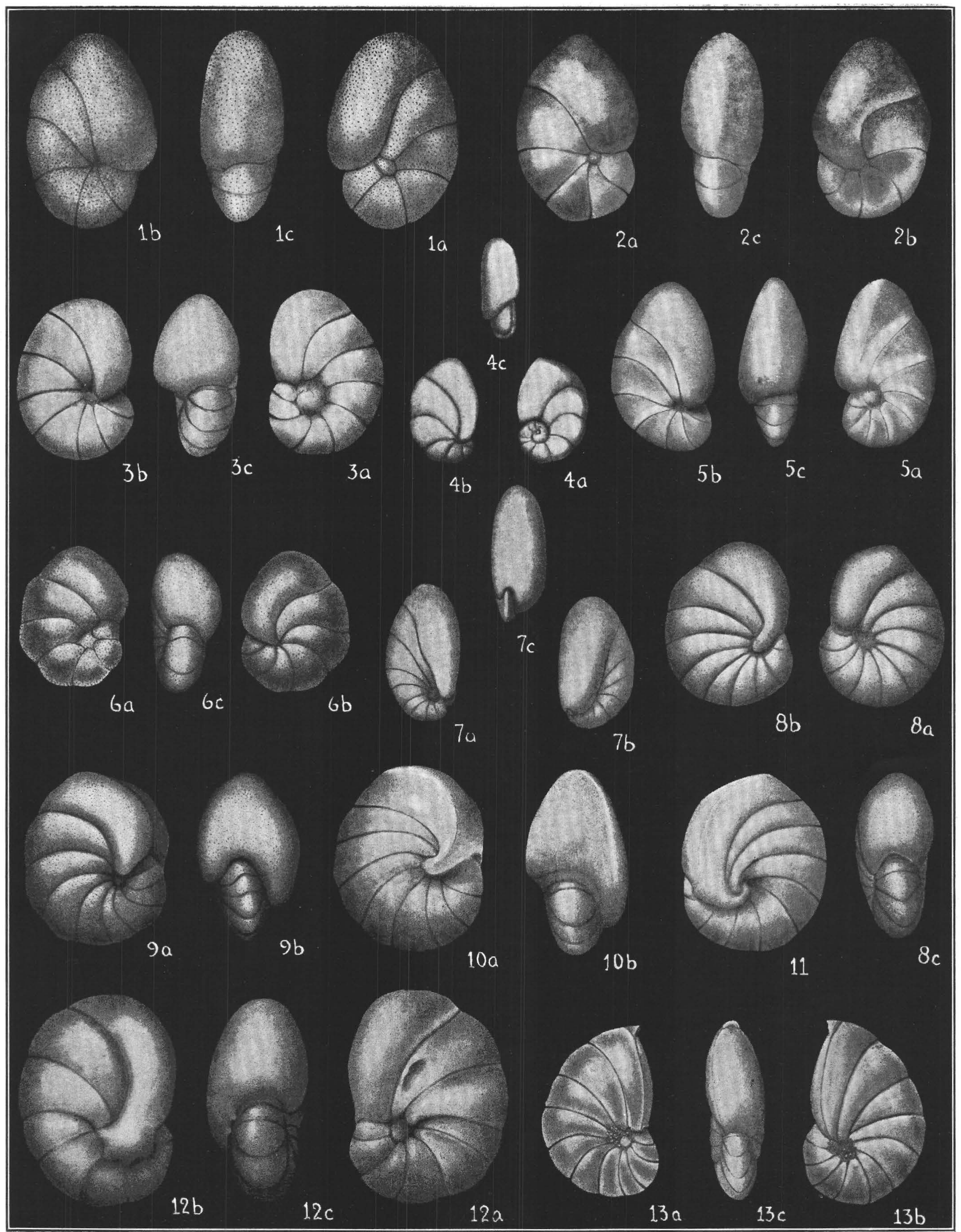




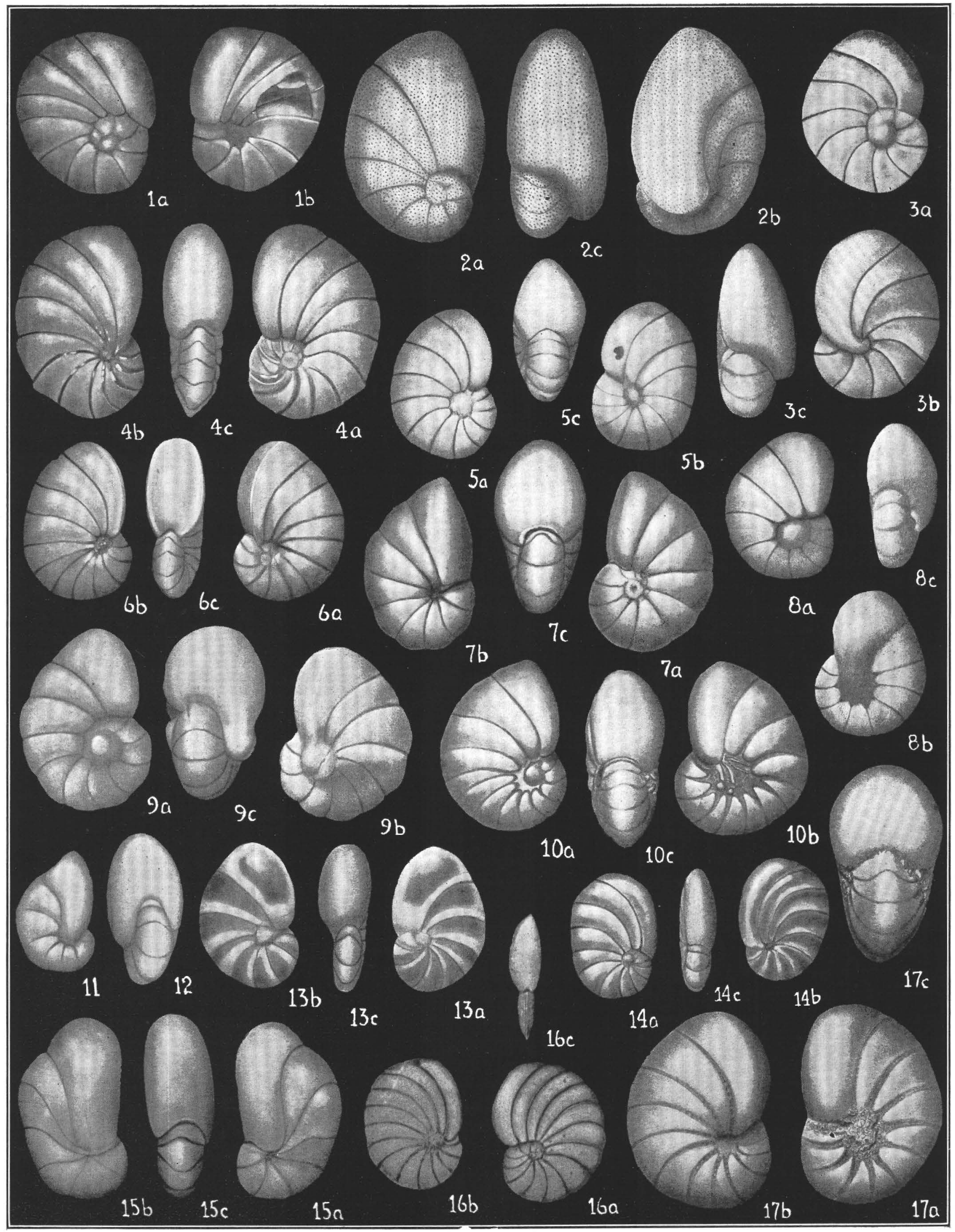

THE FORAMINIFERAL FAMILY NONIONIDAE. 


\section{PLATE 8}

[Unless otherwise designated: a, dorsal view; b, ventral view; c, apertural view]

1. Nonionella insecta (Schwager). Eocene, Wilcox, Alabama. X $115 \ldots$

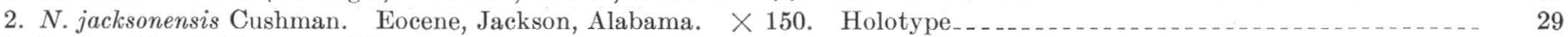

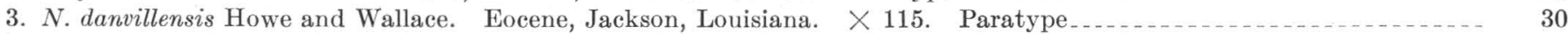

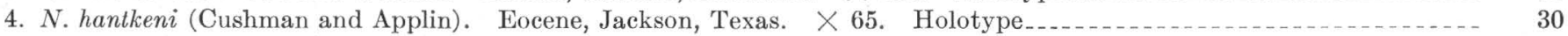

5. N. hantkeni (Cushman and Applin) var. spissa Cushman. Eocene, Jackson, South Carolina. $\times 45$. Holotype_...- 30

6. N. hantkeni (Cushman and Applin) var. fayettei (Cushman and Ellisor). Eocene, Jackson, Louisiana. X $65 . \quad$ Holotype. 30

7. N. frankei Cushman. Oligocene, Germany. X 95. Holotype $\ldots \ldots \ldots$

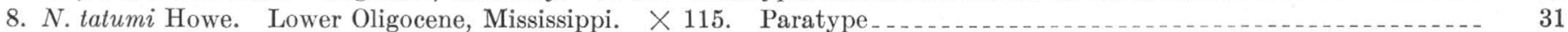

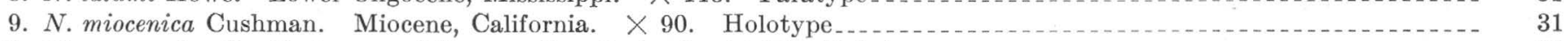

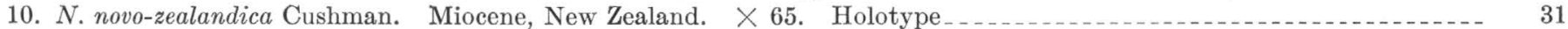

11, 12. N. pseudo-auris Cole. (After Cole.) Pliocene, Florida. $\times 90$. 11, Ventral view; 12, apertural view.......... 31

13, 14. N. limbato-striata Cushman. 13, Pliocene, Fiji, X 150, paratype; 14, Recent, Tonga Islands, $\times 150 \ldots .-. .-\ldots$

15. N. clavata Cushman. Pliocene, Fiji. X 115. Paratype

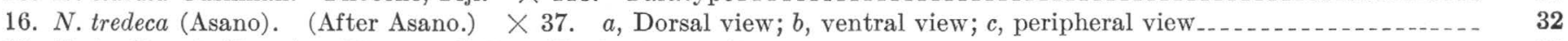

17. N. janiformis (Jones). Pliocene, Sutton, England. X $40 \ldots \ldots$ 


\section{PLATE 9}

1. Nonionella japonica (Asano). (After Asano.) $\times 75$. a, Dorsal view; $b$, ventral view; $c$, peripheral view ..........-

2, 3. N. turgida (Williamson). Recent, southwest Ireland. X 115

4. N. auris (D’Orbigny). Recent, off Payta, Peru. X $90 \ldots$

5. N. iridea Heron-Allen and Earland. (After Heron-Allen and Earland.) Recent, off Falkland Islands. $X$ 115......

6. N. chiliensis Cushman and Kellett. Recent, off Corral, Chile. $\times 90$. Holotype

7-9. N. auricula (Heron-Allen and Earland). (After Heron-Allen and Earland.) Recent, off Plymouth, England.

$\times$ 115. 7, Ventral view; 8, apertural view; 9 , dorsal view

10. N. miocenica Cushman var. stella Cushman and Moyer. Recent, off San Pedro, Calif. X $75 . \quad$ Holotype _...-....

11. N. pulchella Hada. (After Hada.) Recent, Mutsu Bay, Japan. $\times 75$

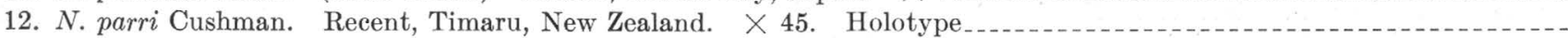

13. N. translucens Cushman. Recent, Levuka, Fiji. $\times 65$. Holotype

14. N. lata Cushman and Valentine. Recent, off Channel Islands, Calif. X 55. Holotype....................

15-18. Cushmanella brownii (D'Orbigny). 15, After D'Orbigny, 1839, a, side view; $b$, apertural view; 16-18, after Palmer and Bermúdez: 16, Recent, Havana, $a$, side view; $b$, apertural view, $\times 28 ; 17$, broken chamber showing supplementary partition connecting the septal aperture with basal portion of preceding chamber, $\times 40 ; 18$, broken chamber, apertural view, showing boundaries of the supplementary partition, $\times 55$ 


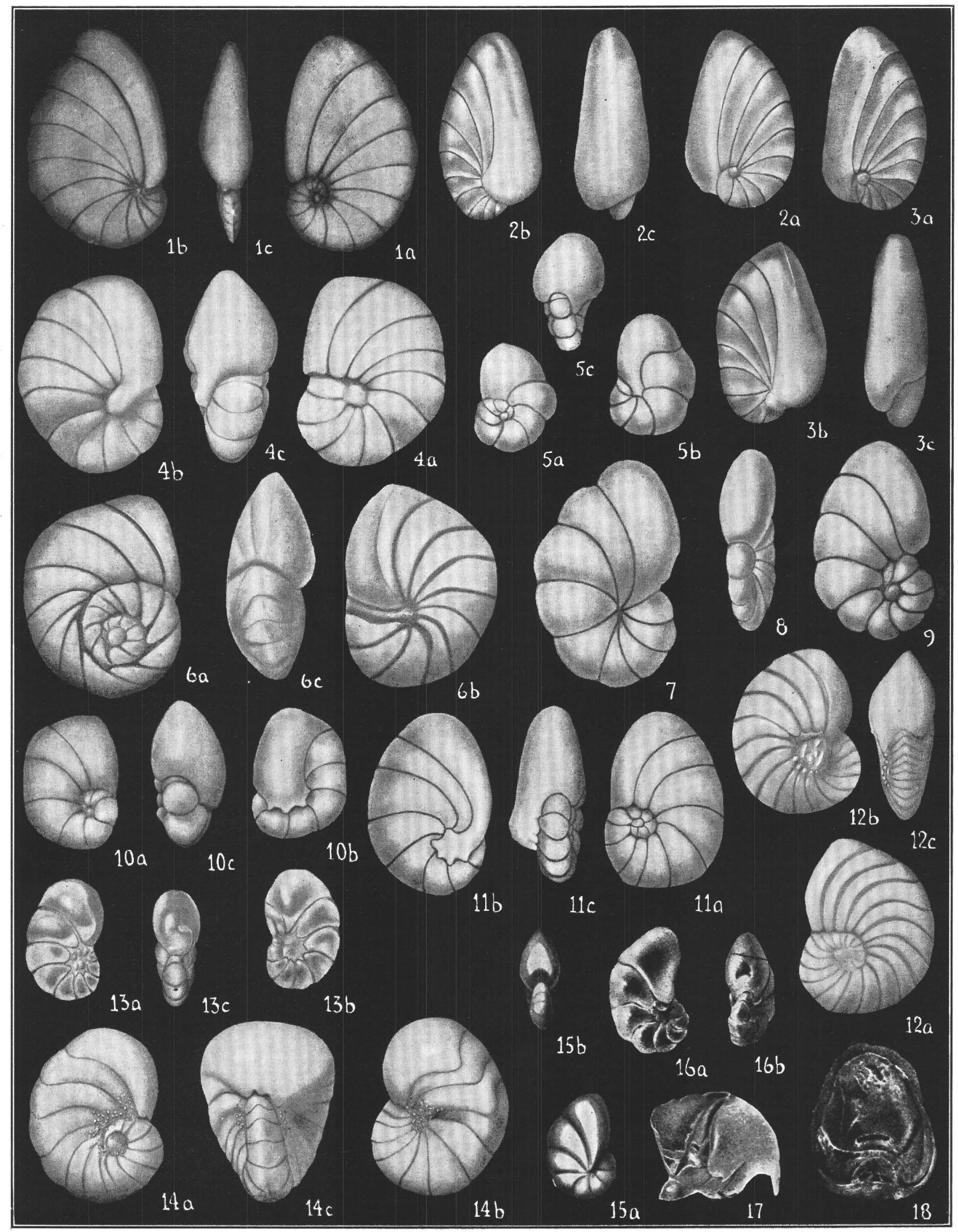

THE FORAMINIFERAL FAMILY NONIONIDAE. 


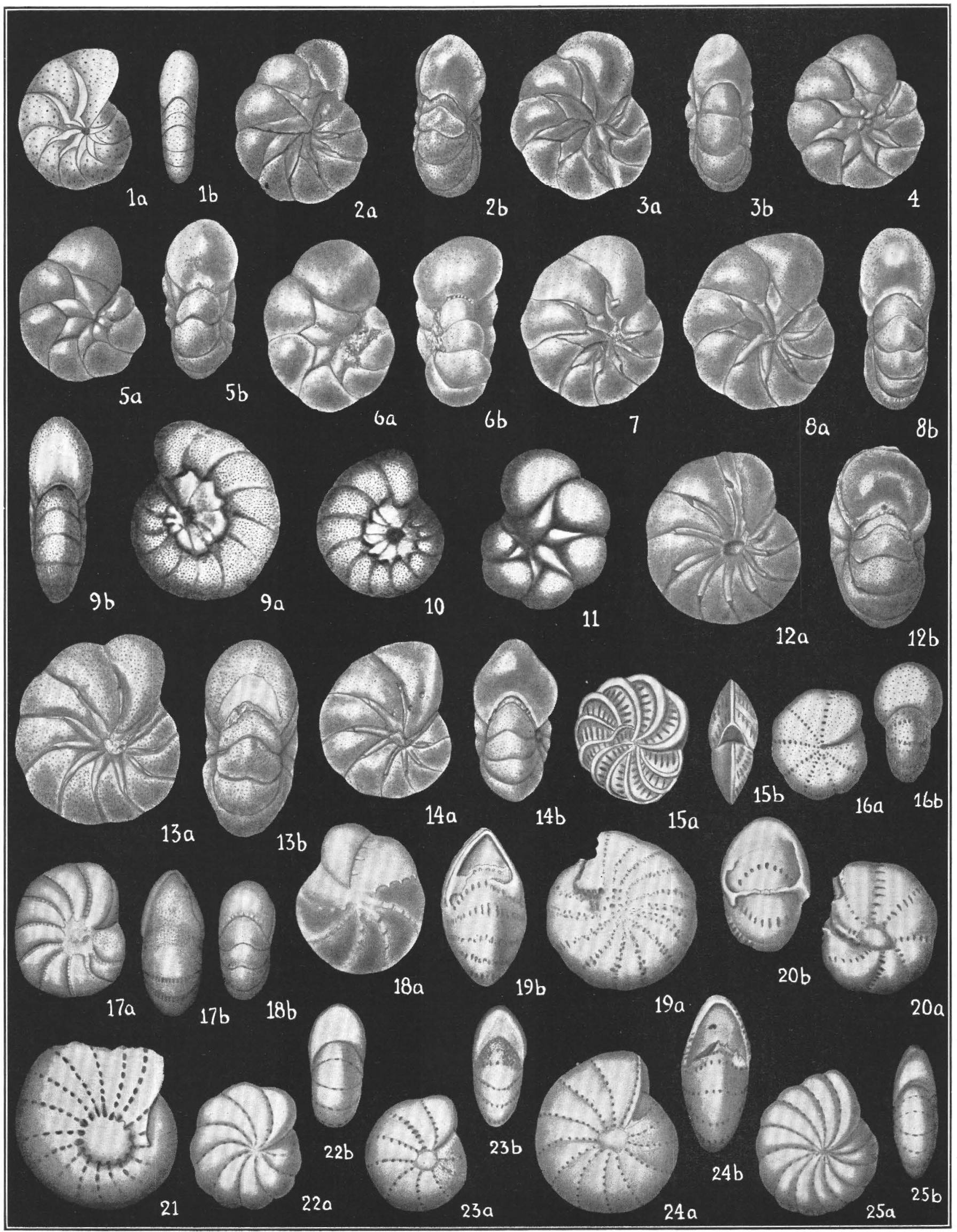

THE FORAMINIFERAL FAMILY NONIONIDAE. 


\section{PLATE 10}

[Unless otherwise designated: $a$, side view; $b$, apertural view]

1. Astrononion stelligerum (D'Orbigny). (After D'Orbigny) $=-$ -

36

2. A. sidebottomi Cushman and Edwards. $\times 25$. Holotype

3-5. A. stellatum Cushman and Edwards. 3, Holotype, off Iceland, $\times 30 ; 4,5$, Porcupine sta. $8: 4, \times 30 ; 5, \times 40 \ldots$

6. A. viragoense Cushman and Edwards. $\times 50$. Holotype _ _ _ _

7, 8. A. australe Cushman and Edwards. 7, $\times 27$, Pliocene, Beaumaris, Victoria; 8 , holotype, $\times 33$. Oligocene, Muddy

Creek, Victoria

9, 10. A. fijiense Cushman and Edwards. (After H. B. Brady.) $\times 40$. Recent, Fiji. 9, Holotype; 10, paratype

11. A. tumidum Cushman and Edwards. $\times$ 40. Recent, off Ascension Island .

12. A. novo-zealandicum Cushman and Edwards. $\times$ 27. Recent, off New Zealand

13, 14. A. italicum Cushman and Edwards. 13, Holotype, $\times 27 ; 14$, paratype, $\times 33 \ldots$

15. Elphidium costiferum (Terquem). (After Terquem.) Eocene?, Paris Basin

16. E. latidorsatum (Reuss). (After Reuss.) Upper Eocene, Germany _...

17. E. texanum (Cushman and Applin). Upper Eocene, Texas. $\times 40$. Holotype.

18. E. eocenicum Cushman and Ellisor. Upper Eocene, Texas. $\times 65$. Holotype

19. E. smithi Cushman and Dusenbury. Upper Eocene, California. $\times 40$. Holotype

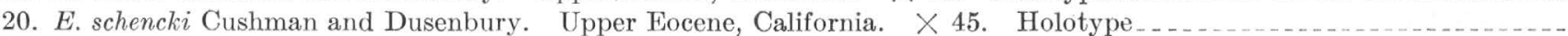

21. E. sp. (?) (After Howe and Wallace.) Upper Eocene, Louisiana

22-25. E. minulum (Reuss). Upper Oligocene, Germany. 22, After Reuss; 23, 24, specimens from near Hildesheim, Germany, $\times 60 ; 25$, "Polystomella discrepans", after Reuss $\ldots$ 


\section{PLA'TE 11}

[In all figures: $a$, side view; $b$, apertural view]

2. E. subnodosum (Münster), Oligocene, Astrupp, near Osnabrück, Germany. $\times 30$

3. E. crassatum Cushman. Oligocene, Australia. $\times$ 55. Holotype

4. E. howchini Cushman. Oligocene, Australia. \ 45. Holotype

5. E. panamense Cushman. Oligocene, Panama Canal Zone. X 65 . Holotype $\ldots$

6. E. culebrense Cushman. Oligocene, Panama Canal Zone. \ 40 . Holotype

7. E. subplanatum Cushman. Oligocene, Germany. \55. Holotype.

8. E. pseudoinflatum Cushman. Oligocene, Australia. $\times 55$. Holotype

9. E. hauerinum (D'Orbigny). Miocene, Nussdorf, near Vienna. $\times 55$. Topotype $\ldots$

10, 11. E. rugosum (D’Orbigny). 10, Miocene, Baden, near Vienna, $\times$ 35, topotype; 11, Miocene, Heiligenstadt, near Vienna, $\times 55$

12. E. fichtellianum (D'Orbigny). Miocene, Nussdorf, near Vienna, $\times 55$. Topotype

13. E. flexuosum (D'Orbigny). Miocene, Vöslau, near Vienna. $\times 35$. Topotype

14. E. antoninum (D'Orbigny). Miocene, Nussdorf, near Vienna. $\times 45$. Topotype

15. E. josephinum (D'Orbigny). Miocene, Baden, near Vienna. $\times 55$. Topotype

16. E. aculeatum (D'Orbigny). Miocene, Baden, near Vienna. $\times 35$. Topotype

17. E. reginum (D’Orbigny) var. caucasicum Bogdanowicz. (After Bogdanowicz.) Miocene, southern Russia. $\times 32$

18. E. subumbilicatum (Czjzek). (After Czjzek.) Miocene, Austria

19. E. reginum (D’Orbigny). Miocene, Baden, near Vienna. $\times 22$. Topotype

20. E. ungeri (Reuss). Miocene, Niederlies, Austria. $\times 65$

21. E. subumbilicatum (Czjzek) var. centronondepressum (Beutler). (After Beutler.) -

22. E. cryptostomum (Egger). Miocene, Ortenburg, Germany. $\times 65$. Topotype 


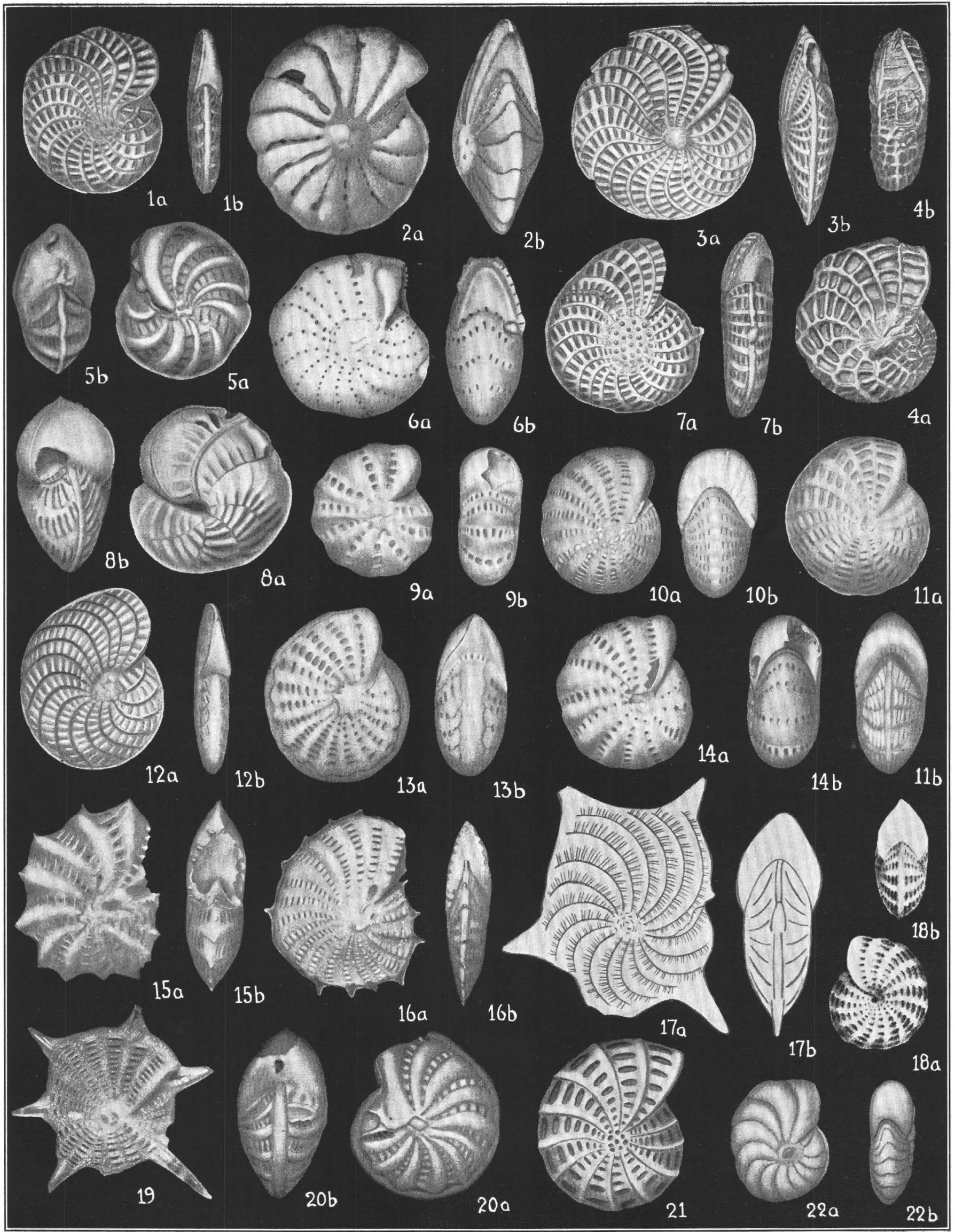

THE FORAMINIFERAL FAMILY NONIONIDAE. 


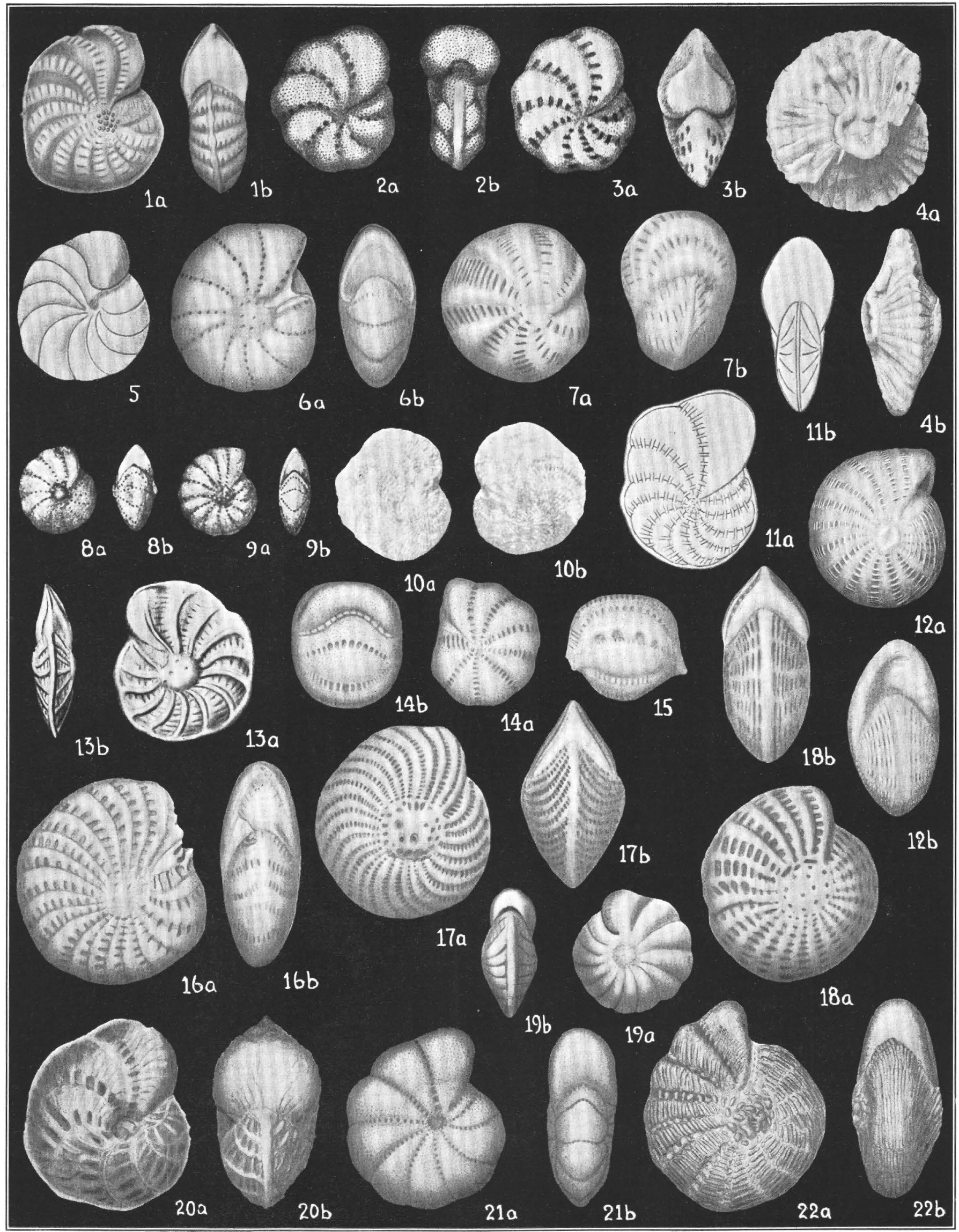

THE FORAMINIFERAL FAMILY NONIONIDAE. 


\section{PLATE 12}

[Unless otherwise designated: a, side view; b, apertural view]

1. Elphidium artenburgense (Egger) - Miocene, Ortenburg Germany $\times 65$ Topotype

2. E. subcarinatum (Egger). (After Egger.) Miocene, Germany $\ldots \ldots$

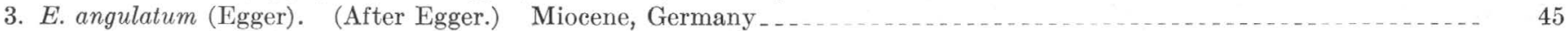

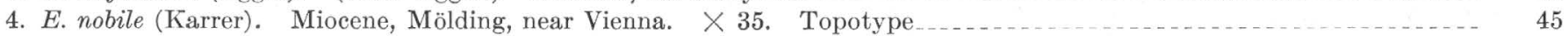

5, 6. E. falunicum (Allix). 5, After Allix; 6, Miocene, St. Arit, France, X $60 \ldots$

7. E. inflatum (Reuss). Miocene, Dingden, Germany. X 55. Topotype

8, 9. E. strattoni (Applin, Ellisor, and Kniker). (After Applin, Ellisor, and Kniker.) Miocene, Texas_........... 46

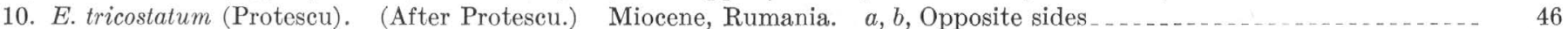

11. E. macellum (Fichtel and Moll) var. tumidocamerale Bogdanowicz. (After Bogdanowicz.) Miocene, southern Russia. $\times 65 \ldots$

12. E. chipolense (Cushman). Miocene, Florida. X 55. Holotype

13. E. fimbriatulum (Cushman). Miocene, Florida. $\times 40 \ldots$

14, 15. E. subsphaericum Cushman and Hedberg. Miocene, Venezuela. $\times$ 55. 14, Holotype; 15, paratype_.......... 47

16. E. glabratum Cushman, n. sp. Miocene, St. Arit, France. $\times 55$. Holotype

17. E. chapmani Cushman. Miocene, Australia. X 28. Holotype

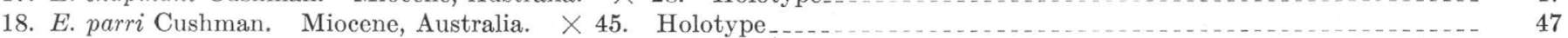

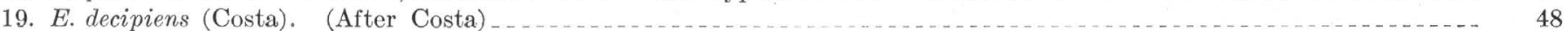

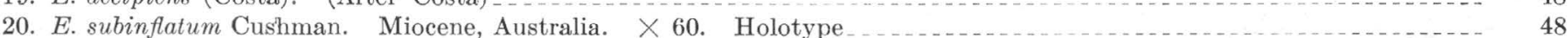

21. E. semistriatum (D’Orbigny). Pliocene, Castel Arquato, Italy, $\times 60$. Topotype

22. E. decipiens (Costa). Pliocene, Monte Mario, near Rome. X $40 \ldots$ 


\section{PLATE 13}

[In all figures: a, side view; b, apertural view

1. Elphidium salentinum (Costa). (After Costa.) Pliocene, Italy

2. E. exoletum (Costa). (After Costa.) Pliocene, Italy

3. E. spinulosum (Costa). (After Costa.) Pliocene, Italy

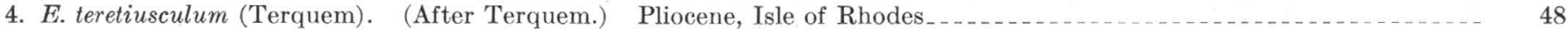

5. E. punctatum (Terquem). (After Terquem.) Pliocene, Isle of Rhodes .

6. E. laminatum (Terquem). (After Terquem.) Pliocene, Isle of Rhodes

7. E. hughesi Cushman and Grant. Pliocene, California. \ 30 . Holotype

8. E. hughesi Cushman and Grant var. foraminosum Cushman, n. var. Pliocene, California. $\times 30$. Holotype_...... 49

9. E. hughesi Cushman and Grant var. obesum Cushman, n. var. Pliocene, California. $\times 30 . \quad$ Holotype_._._._._. 49

10. E. gunteri Cole. (After Cole.) Pliocene, Florida

11. E. ibericum (Schrodt). Pliocene, Monte Mario, near Rome, Italy. \ $55 \ldots \ldots$

12. E. pseudonodosum Cushman. Pliocene, Australia $\times 30$. Holotype

13. E. georgianum Cushman. Late Tertiary, Georges Bank. $\times 35$. Holotype $\ldots \ldots \ldots$.

14-16. E. oregonense Cushman and Grant. 14, Recent, off Cape Blanco, Oregon. X $22.15,16$, Pliocene, Humboldt County, Calif. $\times 30 \ldots \ldots$

17-21. E. crispum (Linné). 17, After Fichtel and Moll; 18, photograph of D'Orbigny's 1826 model; 19 , after H. B. Brady; 20, Recent, Rimini, Italy, $\times 35$, topotype; 21 , Recent, British Columbia, $\times 35 \ldots \ldots$ 


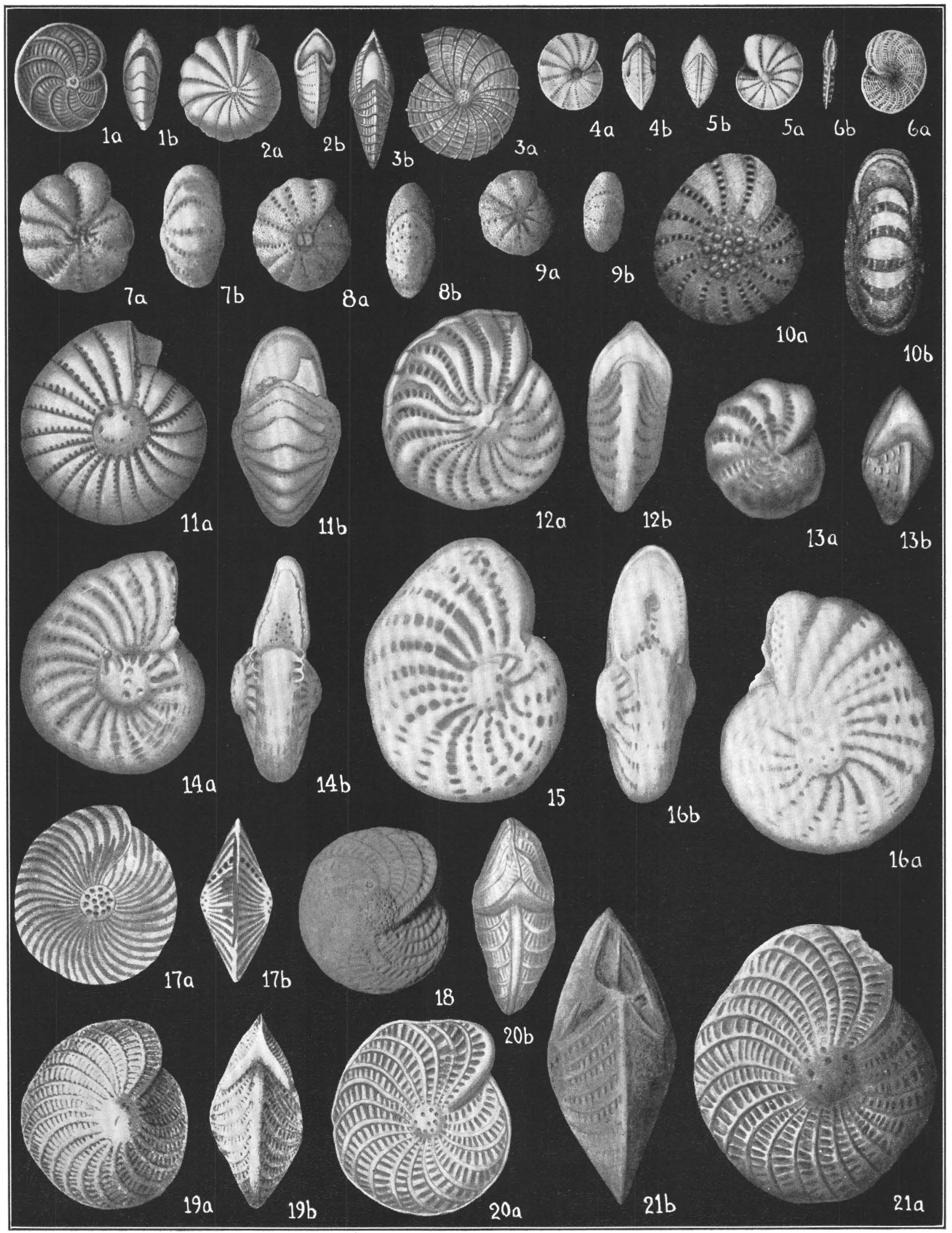

THE FORAMINIFERAL FAMILY NONIONIDAE. 


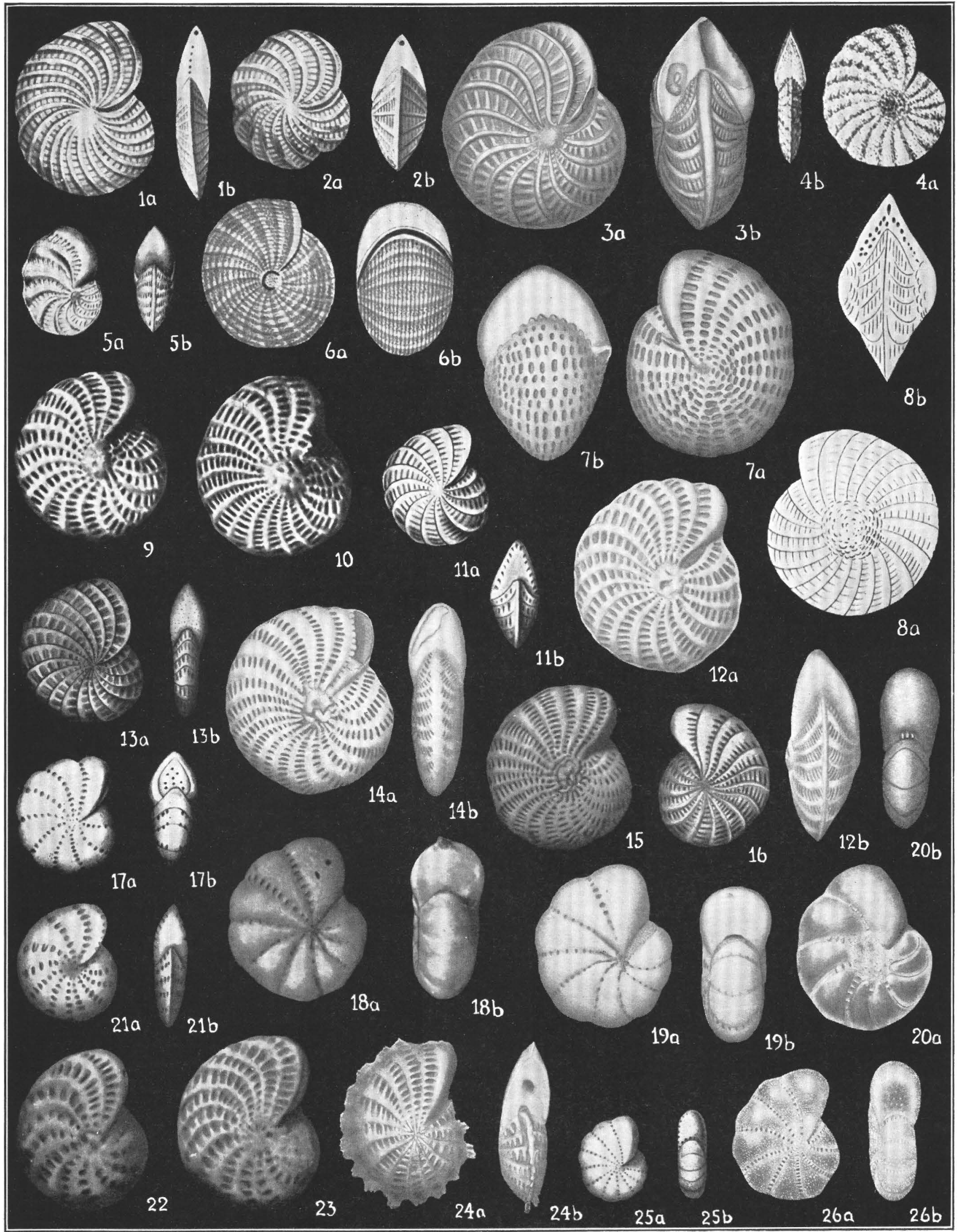

THE FORAMINIFERAL FAMILY NONIONIDAE. 


\section{PLATE 14}

[In all figures: $a$, side view; b, apertural view]

4. E. macellum (Fichtel and Moll) var. granulosum (Sidebottom). (After Sidebottom.) Recent, island of Delos_...... 52

5. E. macellum (Fichtel and Moll) var. limbatum (Chapman). Recent, Pacific. $\times 35$

6, 7. E. striato-punctatum (Fichtel and Moll). 6, After Fichtel and Moll; 7, Recent, Red Sea, × 40 ............. 52

8. E. angulare (D’Orbigny). (After Fornasini, D’Orbigny, 1826)

9-12. E. owenianum (D'Orbigny). 11, After D'Orbigny, 1839; 9, 10, Recent, Falkland Islands, $\times 65$, topotypes . . .... 53

13-16. E. lessonii (D’Orbigny). 13, After D'Orbigny, 1839; 14, 16, Recent, Falkland Islands, $\times 35$, topotypes; 16, after H. B. Brady

17-19. E. articulatum (D’Orbigny). 17, After D’Orbigny, 1839; 18, 19, Recent, Falkland Islands, $\times 60$, topotypes $\ldots . . .$. 20. E. articulatum (D'Orbigny) var. rugulosum Cushman and Wickenden. Recent, Juan Fernandez. $\times 115 . \quad$ Holotype_-

21-23. E. alvarezianum (D'Orbigny). 21, After D’Orbigny, 1839; 22, 23, Recent, Falkland Islands, $\times 45$, topotypes . .....

24. E. alvarezianum (D'Orbigny) var. serrulatum Cushman and Parker. Recent, Falkland Islands. $\times 55$. Holotype

25, 26. E. poeyanum (D’Orbigny). 25, After D’Orbigny, 1839; 26, Recent, Dry Tortugas, Florida, $\times 55$ 


\section{PLATE 15}

[In all figures: a, side view; $b$, apertural view] (D'Orbigny). 1, After D’Orbigny, 1839; 2, 3, Recent, San Juan Harbor, Puerto Rico, X $55 \ldots \ldots$

4. E. lanieri (D’Orbigny). (After D'Orbigny, 1839)

5-7. E. discoidale (D'Orbigny). 5, 7, Recent, Dry Tortugas, Florida: 5, × 55; 7, × 40; 6, after D'Orbigny, 1839 _..... 56

8. E. oceanense (D’Orbigny). (After Fornasini, D’Orbigny, 1826)

9, 10. E. macellum (Fichtel and Moll). 9, "Nautilus strigillatus", after Fichtel and Moll; 10, Recent, Isle of Wight, $\times 45$ _ 51

11-13. E. macellum (Fichtel and Moll) var. aculeatum (Silvestri). 11, 12, Recent, Isle of Wight, $\times 65 ; 13$, after Fichtel and Moll_.......................

14-17. E. craticulatum (Fichtel and Moll). 14, After Fichtel and Moll; 15, 16, after H. B. Brady, $\times 30$; 17, Recent, off Vavau Anchorage, Tonga Islands, $\times 32$, young stage $\ldots \ldots$

18-19 E. complanatum (D'Orbigny). 18, After D'Orbigny, 1839, Recent, Canaries; 19, after Fornasini D'Orbigny, 1839_..-

20. E. berthelotianum (D'Orbigny). (After D'Orbigny, 1839.) Recent, Canaries 21-24. E. incertum (Williamson). 21, After Williamson; 22, after H. B. Brady, $\times 65$; 23, Recent, Casco Bay, Maine, $\times 75$;
24, Recent, Hudson Bay, $\times 75$. 


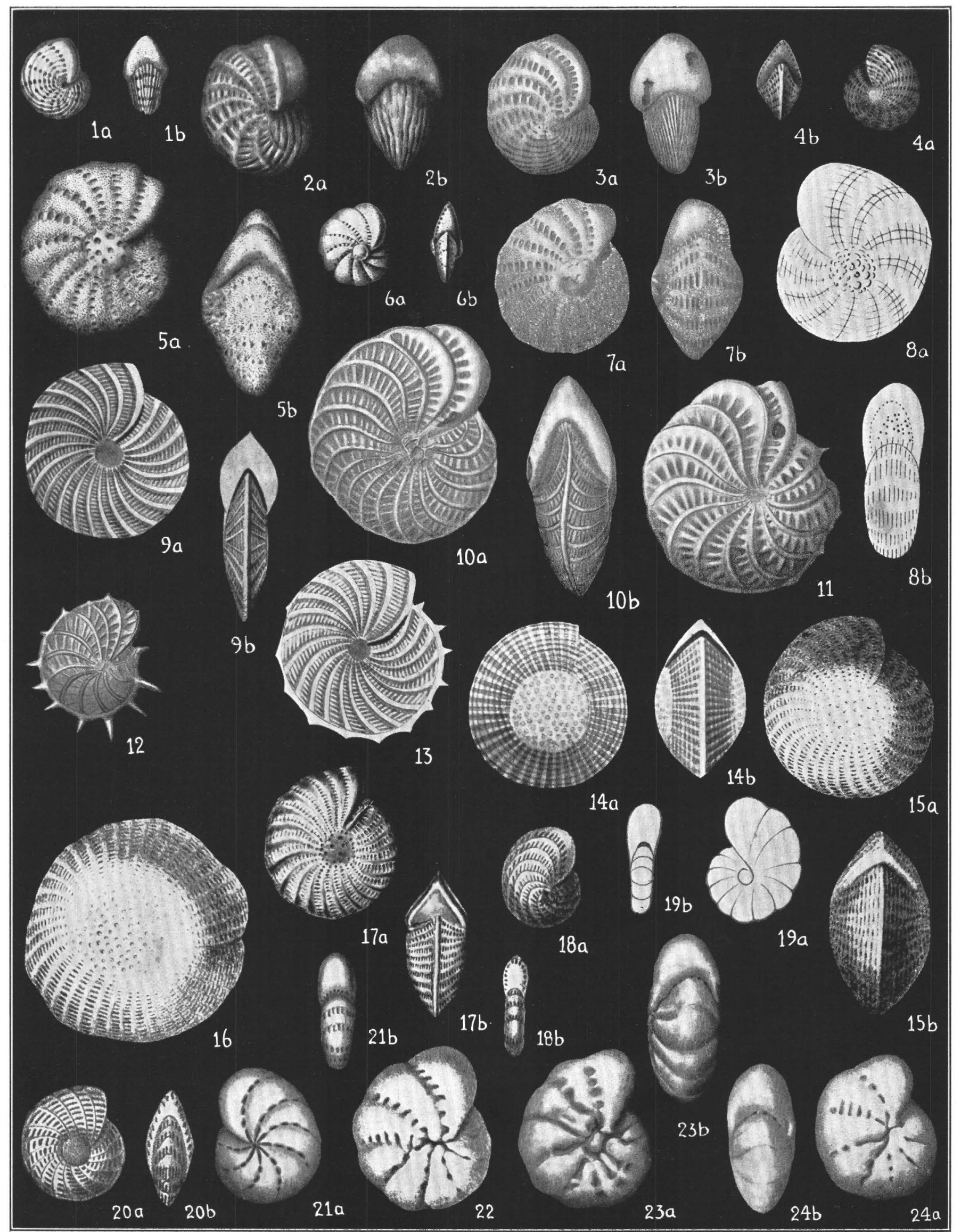

THE FORAMINIFERAL FAMILY NON.ON.DAE. 


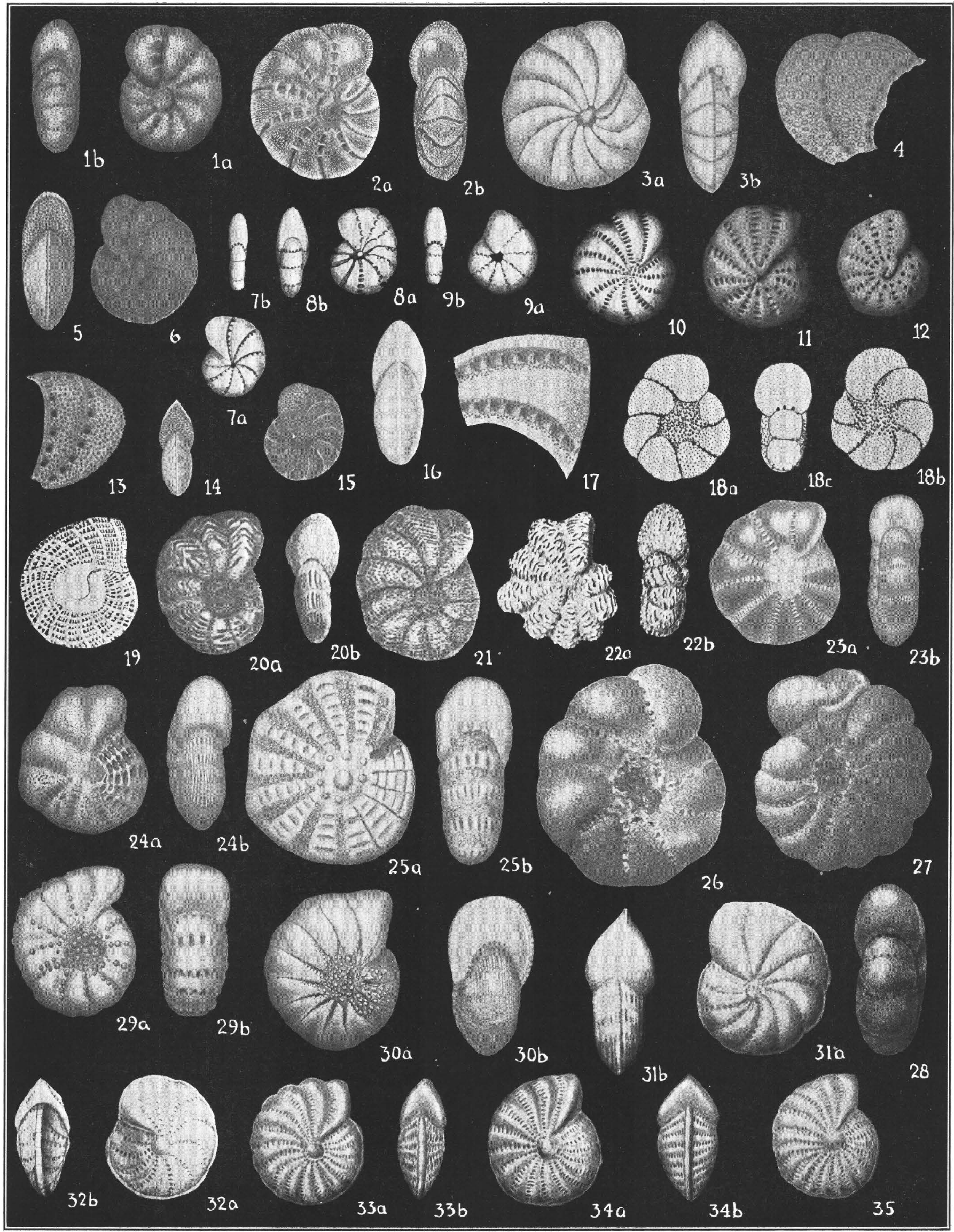

THE FORAMINIFERAL FAMILY NONIONIDAE. 


\section{PLATE 16}

[Unless otherwise designated: a, side view; b, apertural view]

1, 2. Elphidium incertum (Williamson) var. clavatum Cushman. Recent, coast of Maine. X $55 . \quad$ Holotype .......... 57

3. E. incertum (Williamson) var. mexicanum Kornfeld. (After Kornfeld.) Recent, Gulf of Mexico. $\times 75 \ldots . . . . . . . . \quad 57$

4-6. E. gibbum (Schultze). (After Schultze.) 4, Detail of last two chambers; 5, apertural view; 6, side view _.......... 58

7-12. E. excavatum (Terquem). 7-9, After Terquem; 10, after Williamson; 11, 12, Recent, off Bognor, England, X 55_.... 58

13-15. E. venustum (Schultze). (After Schultze.) 13, Detail of surface; 14, apertural view; 15, side view_............. 58

16, 17. E. stella-boreale (Ehrenberg). (After Schultze.) 16, Apertural view; 17, detail of surface_.................... 58

18. E. schmitti Cushman and Wickenden. Recent, Juan Fernandez, Chile. $\times 75$. Holotype. $a, b$, Opposite sides; $c$ apertural view - 58

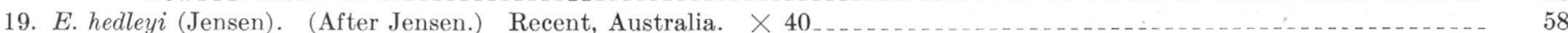

20-22. E. milletti (Heron-Allen and Earland). 20, 21, After Heron-Allen and Earland, Recent, Southeastern Africa, X 60; 22, Recent, Vavau Anchorage, Tonga Islands, X $40 \ldots$

23. E. oceanicum Cushman. Recent, Fiji, $X$ 65. Holotype

24. E. reticulosum Cushman. Recent, Vavau Anchorage, Tonga Islands, X 55. Holotype $\ldots . . . . . . . . . . . . . . . . . .59$

25. E. gunteri Cole var. galvestonense Kornfeld. (After Kornfeld.) Recent, off Galveston, Tex., X $75 \ldots \ldots 0$

26-28. E. selseyense (Heron-Allen and Earland). (After Heron-Allen and Earland.) Recent, Selsey Bill, England, X 65_-- 59

29. E. morenoi Bermúdez. Recent, Cuba, X 30. Cotype

30. E. australe Cushman and Parker. Recent, Falkland Islands, $\times 55$. Holotype........................... 60

31-35. E. advenum (Cushman). 31, Recent, Dry Tortugas, Florida, $\times$ 75; 32, after H. B. Brady, $\times$ 55; 33-35, Recent,

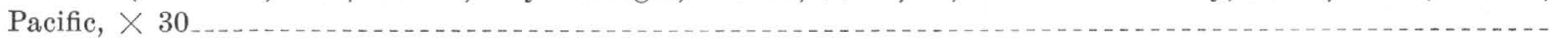




\section{PLATE 17}

1. Elphidium advenum (Cushman) var. depressulum Cushman Recent, Fiji. $\times 55$. Holotype

2. E. advenum (Cushman) var. margaritaceum Cushman. Recent, Newport, R. I. $\times 65$. Holotype

3. E. advenum (Cushman) var. ponticum Dolgopolskaja and Pauli. (After Dolgopolskaja and Pauli.) Recent, Black Sea_

4. E. minimum (Seguenza). (After Seguenza.) Pliocene, Sicily

5-9. E. imperatrix (H. B. Brady). 5-7, After H. B. Brady, Recent, Storm Bay, Tasmania, X 30; 8, 9, after Proteseu _...

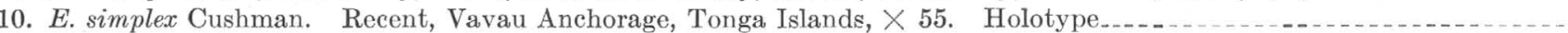

11, 12. E. magellanicum Heron-Allen and Earland. (After Heron-Allen and Earland.) Recent, Straits of Magellan. $\times 55$

13. E. verriculatum (H. B. Brady). (After H. B. Brady.) Recent, Bass Strait, Australia. X $55 \ldots \ldots$

14, 15. E. jenseni Cushman. Recent, Fiji. $\times 35 \ldots$

16. E. indicum Cushman. Recent, Bombay, India. X 50. Holotype

17. E. lidoense Cushman. Recent, Lido, Venice, Italy. $\times$ 65. Holotype

18. E. novo-zealandicum Cushman. Recent, Dusky Sound, New Zealand. $X 60$. Holotype

19. E. nigarense Cushman. Recent, Nigare, Greece. $\times 90$. Holotype 


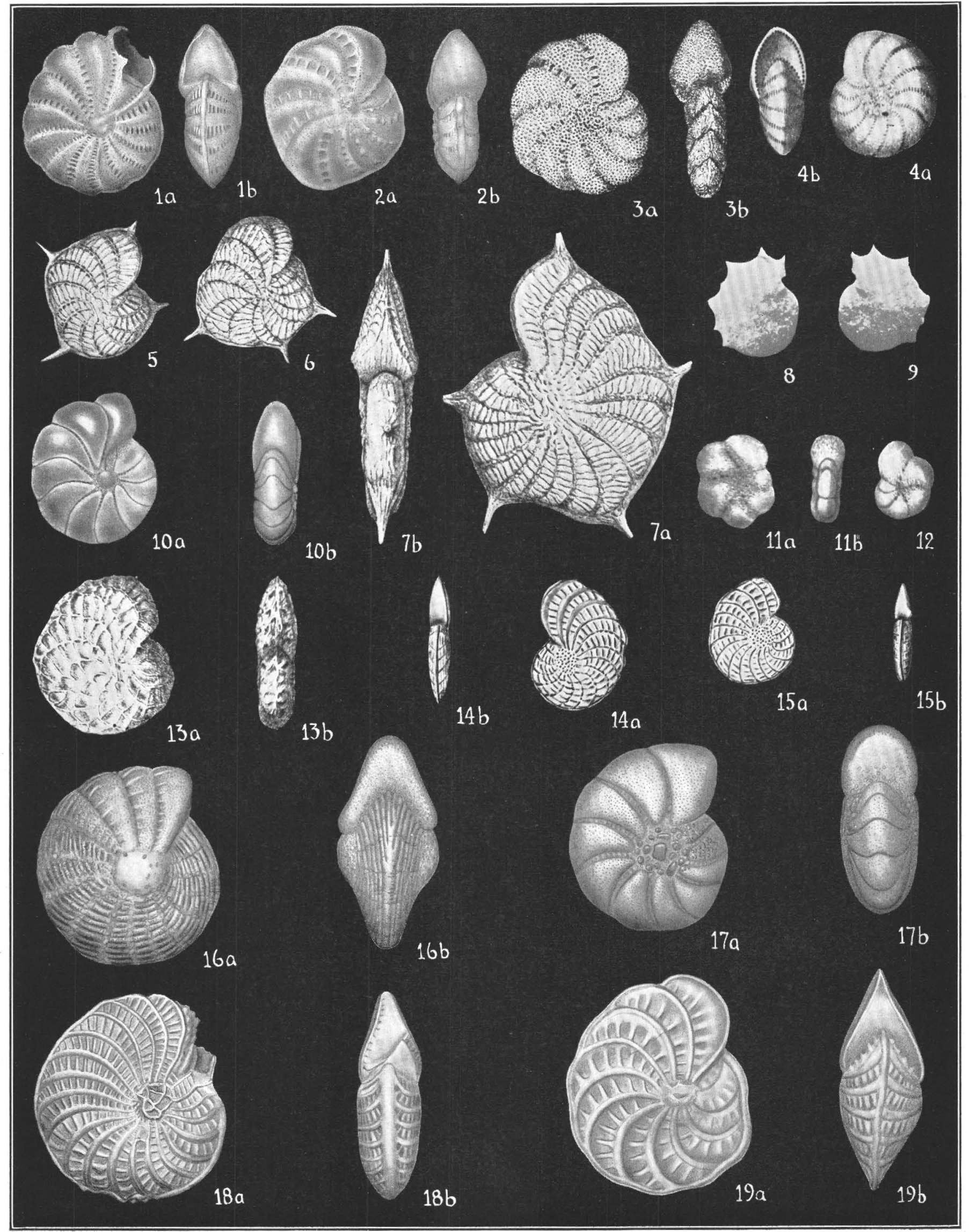

THE FORAMINIFERAL FAMILY NONIONIDAE. 


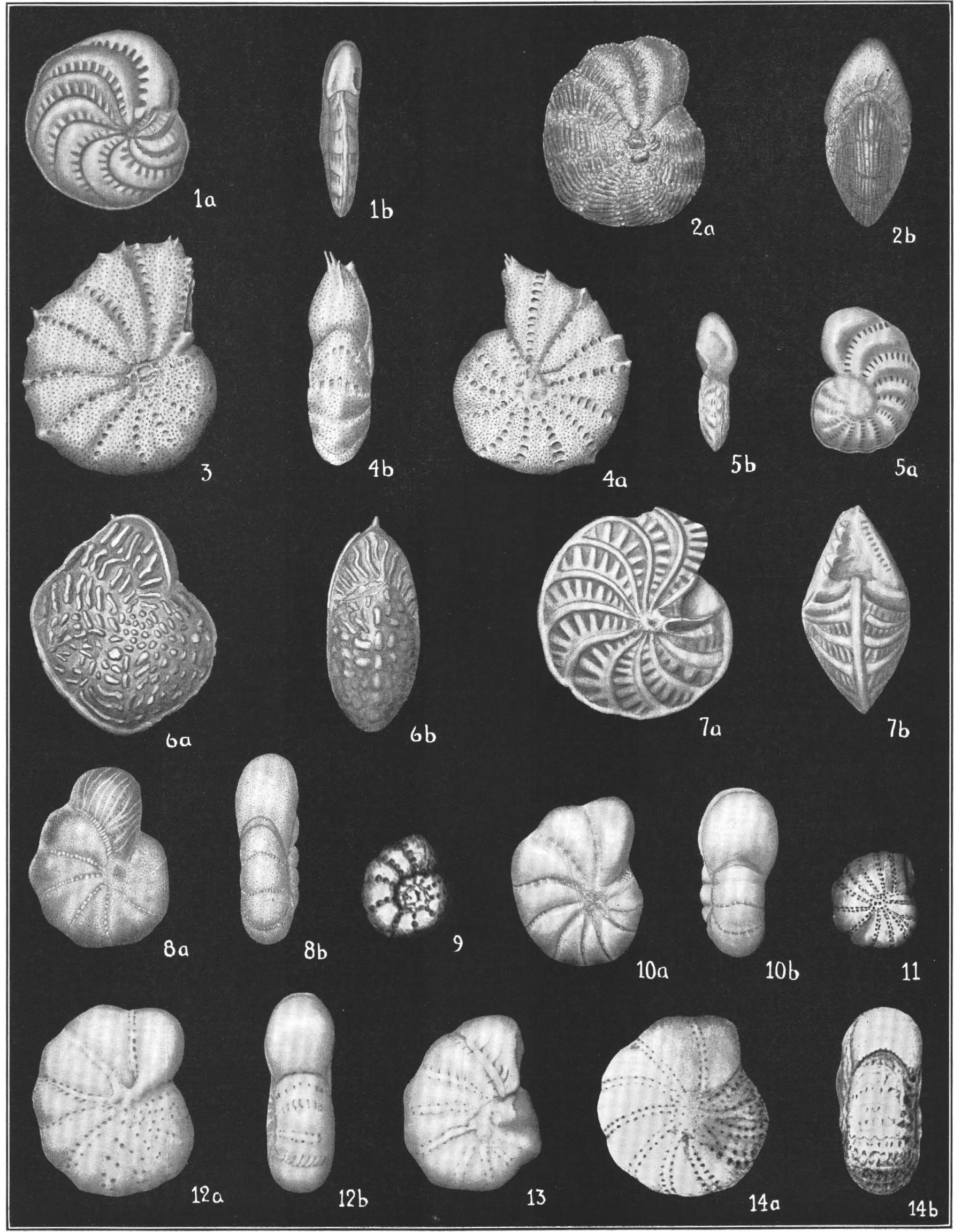

THE FORAMINIFERAL FAMILY NONIONIDAE, 


\section{PLATE 18}

[In all figures: a, side view; b, apertural view]

1. Elphidium earlandi Cushman. Recent, southwest coast of Spain. $\times 65$. Holotype

2. E. hispidulum Cushman. Recent, Albany Passage, Australia. $\times 65$. Holotype

3, 4. E. spinatum Cushman and Valentine. Recent, off Channel Islands, Calif. X 55. 3, Holotype; 4, paratype _.... $\quad 63$

5. E. subevolutum Cushman. Recent, Rotonga. X 45. Holotype

6. E. papillosum Cushman. Recent, 16 miles east of Wollongong, New South Wales. $\times 65$. Holotype............ 64

7. E. sculpturatum Cushman. Recent, off Melbourne, Australia. $\times 90$. Holotype

8. E. frigidum Cushman. Recent, Fox Basin, Greenland. X 40. Holotype

9. E. evolutum (Chapman). (After Chapman)

10. E. bartletti Cushman. Recent, off Labrador, $\times 40$. Holotype

11-14. Elphidiella arctica (Parker and Jones). 11, After Dawson, Recent, Gaspé Bay; 12, 13, Recent, Gaspé Bay, X 40; 14, after H. B. Brady, Recent, Smith Sound, $\times 28$ 


\section{PLATE 19}

[Unless otherwise designated: $a$, dorsal view; $b$. ventral view; $c$, apertural view]

1, 2. Elphidiella hannai (Cushman and Grant). 1, Recent, off Farallon Islands, Calif., $\times$ 40, holotype; 2, Recent. Monterey Bay, Calif., $\times 45 . \quad a, a$, Side views; $b, b$, apertural views $\ldots$

3. E. groenlandica (Cushman). Recent, off northeast Greenland. $\times 40$. Holotype. $a$, Side view; $b$, apertural view...--

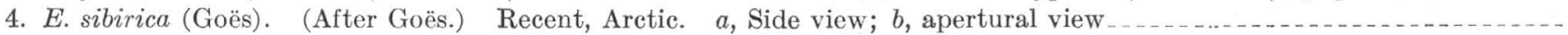
5-8. Ozawaia tongaensic Cushman. 5, $6, \times 45$, early stages(?): $5 a$, Side view; $b$, apertural view; 7 , Recent, Vavau Anchorage, Tonga Islands, $\times 45$, holotype: $a$, Side view; $b$, apertural view; 8 , after Millett, Recent, Malay Archipelago, $\times 45$

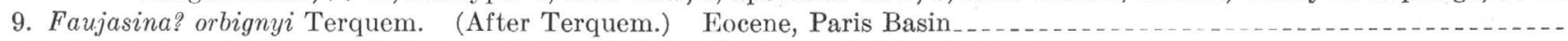

10. F. carinata D'Orbigny. (After D'Orbigny, 1846.) Cretaceous?, Maestricht?

11, 12. Polystomellina discorbinoides Yabe and Hanzawa. 11, After Yabe and Hanzawa, $\times 22 ; 12, \times 40 \ldots \ldots$

13. P. miocenica Cushman. Miocene, Batesford, Australia. X 40. Holotype

14. P. australis Cushman. Recent, Gulf of Carpentaria. × 65. Holotype

Page

66

66

66 


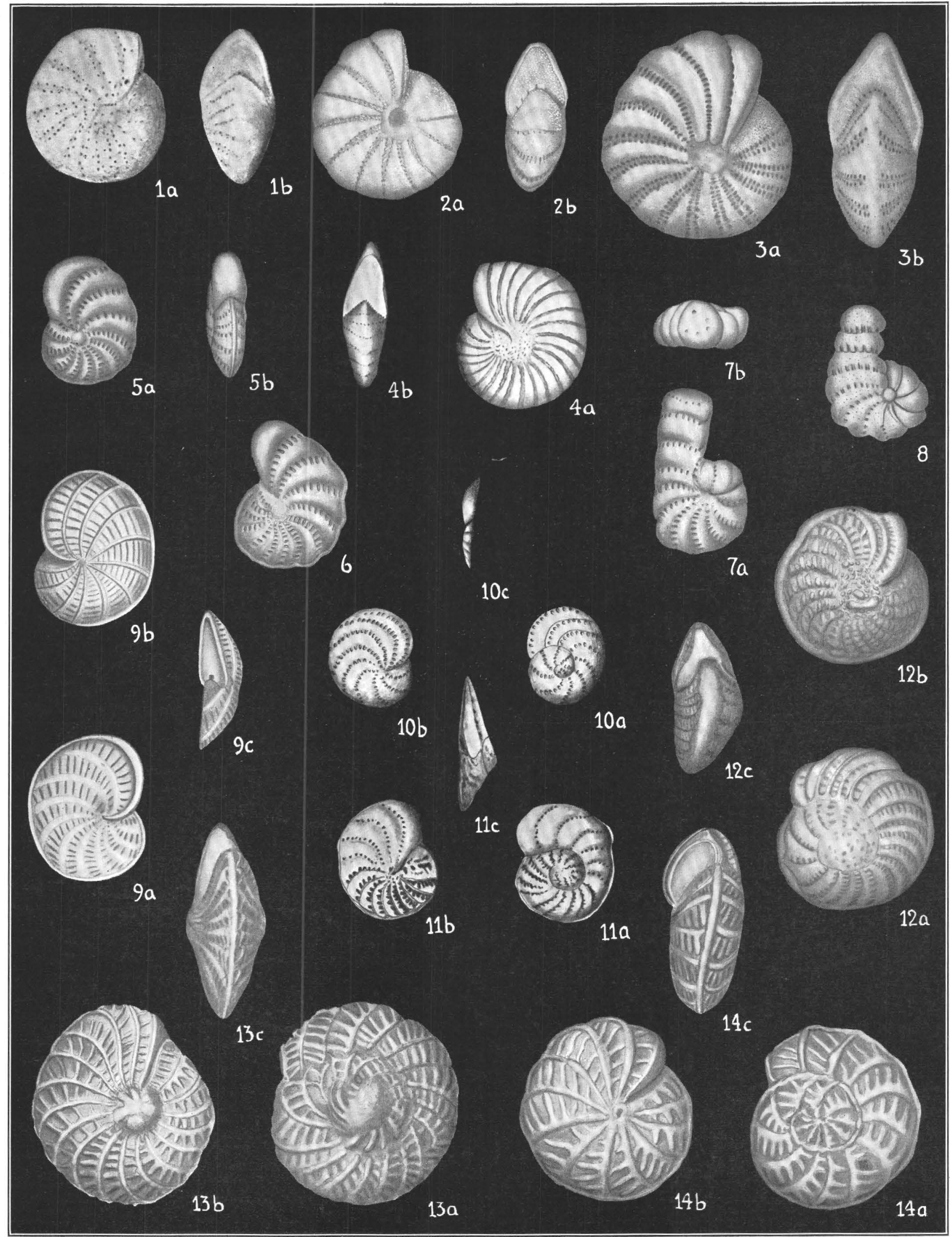

THE FORAMINIFERAL FAMILY NONIONIDAE. 


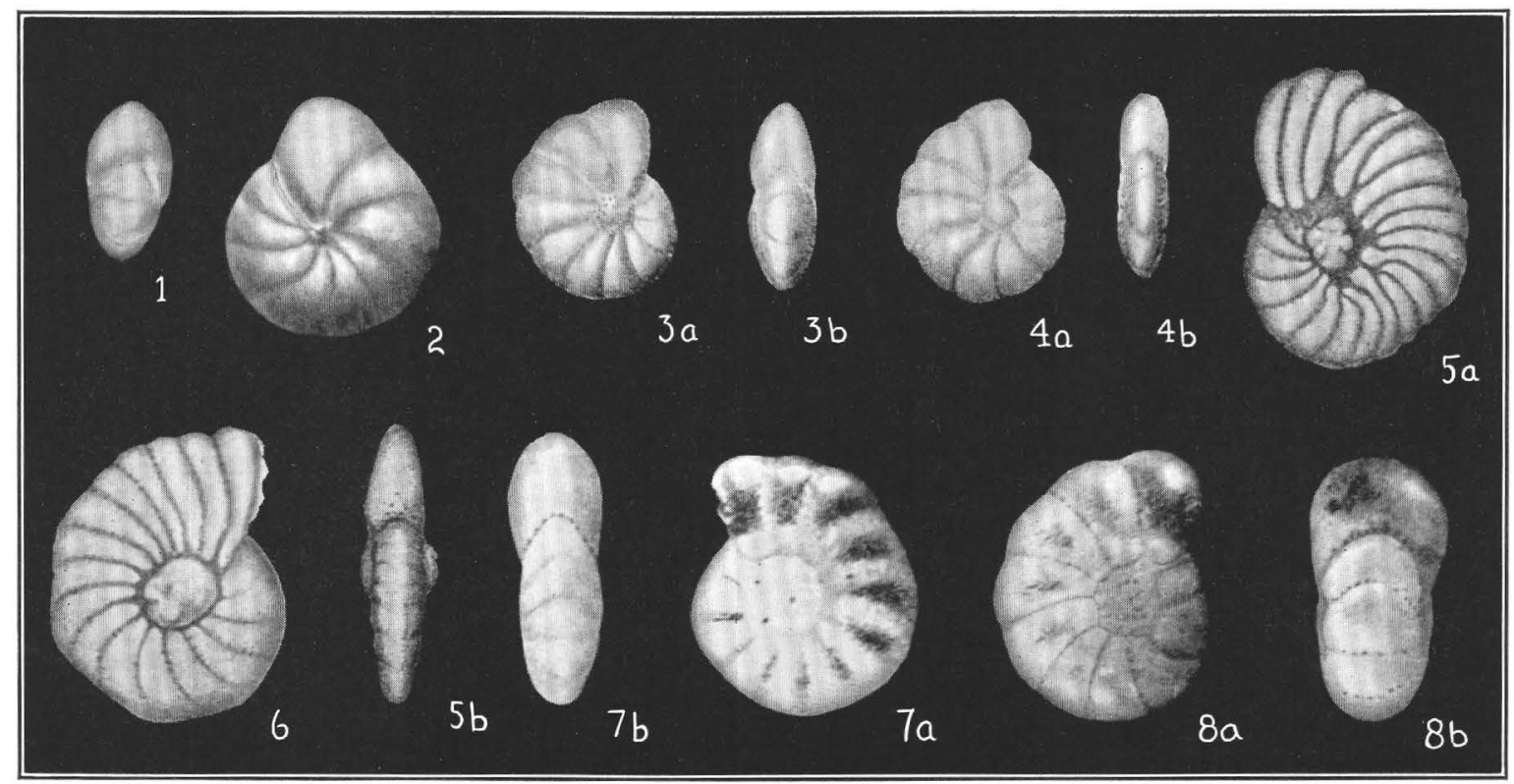

THE FORAMINIFERAL FAMILY NONIONIDAE. 


\section{PLATE 20}

Page

1, 2. Nonion havanense Cushman and Bermúdez. (After Cushman and Bermúdez.) $\times 60$. 1, Paratype. 2, Holotype.-

3, 4. N. advenum (Cushman), $\times 40$. 3a, 4a, Side views; $3 b, 4 b$, apertural views .

5, 6. Elphidium ezoense Asano, $\times 33$. 5, Holotype; $a$, side view; $b$, apertural view. 6, Paratype, after Asano........

7. E. translucens Natland. (After Natland.) $\times 60$. $a$, Side view; $b$, apertural view

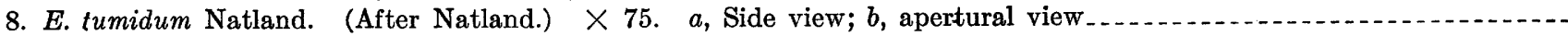




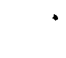




\section{INDEX}

Page

acervata, Nonionina

Acknowledgment for aid

aculeata, Polystomel Polystomella macella

aculeatum, Elphidium

Elphidium macellum

advena, Nonionina

Polystomelle

26

44

52

44, pl. 11

52 , pl. 15

advenum, Elphidium

Elphidium (Polystomella)

7,9

Nonion

aequivoca, Polystomella

affine, Nonion

affinis, Nonionina

Planulina

Pulvinulina

aglajae, Nonionina

alabamensis.

alvareziana, Polystomella

alvarezianum, Elphidium

ambiguus, Nautilus.

Andromedes.

angulare, Elphidium.

angularis, Polystomella

angulata, Polystomell

angulatum, Elphidium.

angustum, Nonion.

Anomalina

(17, pl. 4

anomalina, Nonionina........ 9

anomalinum, Nonion

antonina, Polystomella

antoninum, Elphidium.

applini, Nonion.

43,45, pl. 11

archetypus, Nonionina

arctica, Elphidiella

$8, \mathrm{pl} .2$

iella............... $65-66$, pl. 18

Nonionina.

Polystomella

arcticum, Elphidium

65

65-66

arenacea, Nonion turgida.............. 26

armatum, Nonion boueanum
articulata, Polystomella..... 6 , 6

articulatum, Elphidium

$53-54,65$, pl. 14

asterizans, Nautilus

Nonion

20,32,37

astreae, Nonionina

Astrononion.

作 10

(10

novo-zeałandicum

sidebottomi

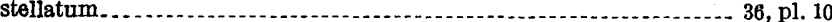

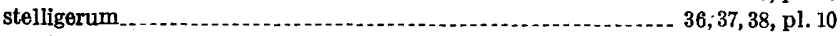

tumidum. .......

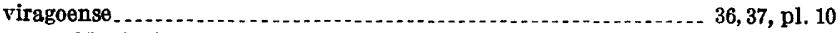

attenuata, Nonionia

attenuatum, Nonion

auricula, Nonionella

17

auris, Nonionella.

..- $17, \mathrm{pl}, 4$

Valvulina.

$31,32,33$, pl. 9

austinana, Nonionella

australe, Astronionion.

Elphidium.

australis, Polystomellina 33

$27, \mathrm{pl} .7$

$37-38$, pl. 10

$60, \mathrm{pl} .16$

B

barleeana, Nonionina

barleeanum, Nonion.
Page

bartletti, Elphidium............

basispinatum, Nonion pizarrense . . . . . . .

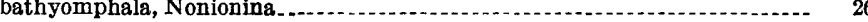

bavarica, Nonionina

belridgense, Nonion

berthelotiana, Polystomella_......... 56

berthelotianum, Elphidium................ 56-57, pl. 15

birmenstorfensis, Noniorina . . . . . . . . . . . .

bonairense, Nonion.

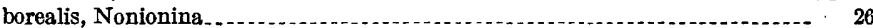

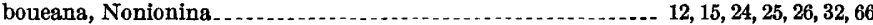

boueanum, Nonion . .

boveana, Nonion.

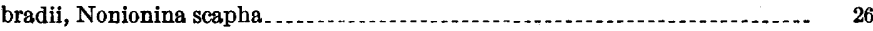

Bradyina.

brooklynense, Elphidium

brownii, Cushmanella . . .

Nonion

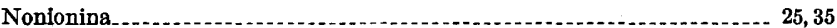

bulloides, Nonionina.

burdigalensis, Polystomella

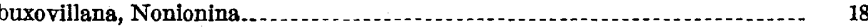

buxovillanum, Nonion

67

26

25
Polystomella.

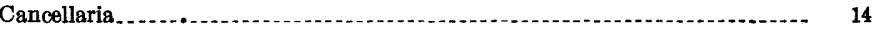

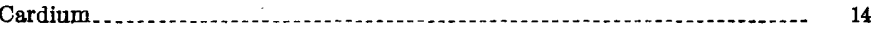

carinata, Faujasina

carmeloense, Nonion montereyanum.

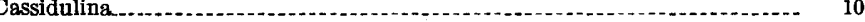

caucasicum, Elphidium reginum

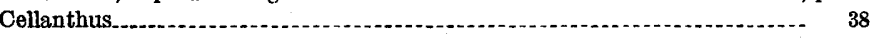

centronondepressum, Elphidium subumbilicatum ........... 11

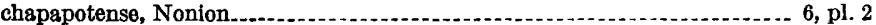

chapmani, Elphidium.................. 12

chiliensis, Nonionella............. 33, pl. 9

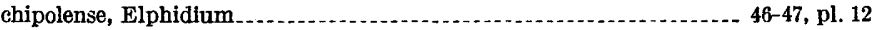

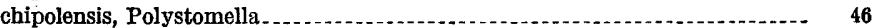

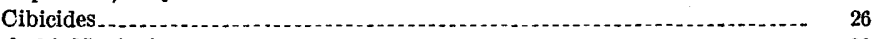

clarki, Nonionina.

clavata, Nonionella....................... 31, pl. 8

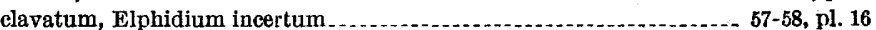

Clavulina szaboi.

cockfieldensis, Nonionella $\ldots \ldots \ldots$. . . pl. 7

commune, Nonion.......................... 10-11, pl. 3

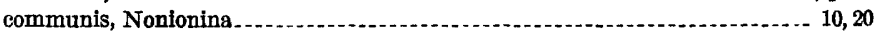

compacta, Nonionina.

complanata, Polystomella.

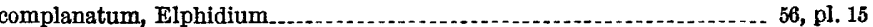

Cornu Hammonis orbiculatum..... $\quad 50$

costata, Nonionina. . .

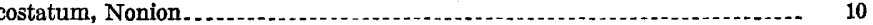

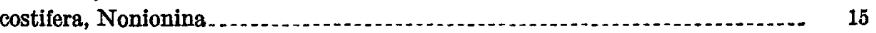

Polystomella.......... 39

costiferum, Elphidium

Nonion

crassatum, Elphidium .

crassula, Nonionina

crassulum, Nonion

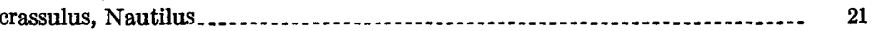

craticulata, Polystomella. .

craticulatum, Elphidium........... 15

craticulatus, Nautilus ....

crespinae, Elphidium . .

cretacea, Nonionella

Nonionina................ 3,26

cretaceum, Nonion.

Cribospira 
Page

crisiae, Nonionina

crispa, Polystomella crispum, Elphidium crispus, Nautilus

Cristellaria.

cryptostoma, Polystomella

cryptostomum, Elphidium

crystallina, Nonionina

culebrense, Elphidium

Cushmanella

brownii.

Cyclammina

danvillense, Nonion.

danvillensis, Nonionelia

decipiens, Elphidium

Polystomella

dense-punctata, Nonionina

dense-punctatum, Nonion

depressula, Nonionina.

Polystomella

depressulum, Elphidium advenum

Nonion

depressulus, Nautilus

dingdeni, Nonion...

discoidale, Elphidium

discoidalis, Polystomella

discorbinoides, Polystomeila (Polystomellina)

Polystomellina Discorbis.

discrepans, Polystomella

dollfusi, Nonion.

earlandi, Elphidium.

elliptica, Nonionina

longata, Nonionina

Pullenia

elongatum, Nonion

Elphidiella

arctica.

groenlandica

hannai

sibirice

Elphidium

aculeatum.

advenum.

depressulum margaritace

Ivarezianum serrulatum.

angulare.

angulatum

antoninum

arcticum.

articulatum.

$$
\text { rugulosum. }
$$

australe

bartletti.

berthelotianum.

brooklynense

chapmani.

chipolense.

complanatum

costiferum

crassatum.

craticulatum

crespinae

crispum.

cryptostomum

culebrense

decipiens.

discoidale

earlandi.

eocenicum

evolutum.

excavatum

exoletum.

ezoense-.

falunicum.

fichtellianum

fimbriatulum.

$38,39,50,58,65,67$ $48,50-51,52$, pl. 13

38, 50

3

5, pl. 11

pl. 11

35, pl. 9

$25,35, \mathrm{pl} .9$

\section{D}

5, pl. 1

$30, \mathrm{pl} .8$

48 , pl. 12

- 48,57

14 , pl. 3

20,24

61, pl. 17 $9,20-21,24$, pl. 5 20 $16, \mathrm{pl} .4$ 56, pl. 15 56 pl 19 26
pl. 10 15 , pl. 4

\section{E}

63 , pl. 18 -....

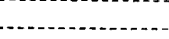

65-67, pls. 18,19 65-66, pl. 18 66-67, pl. 19 66, pl. 19 66, pl. 19 1s. 10-18, 20 44, pl. 11 60-61, pl. 16 61, pl. 17 61, pl. 17 61, pl. 17 54 , pl. 14 54, pl. 14 $53, \mathrm{pl} .14$ 45 , p]. 12 43,45, pl. 11 65-66 $53-54,65$, pl. 14 54, pl. 14 60, pl. 16 64-65, pl. 18 56-57, pl. 15 47, pl. 12 46-47, pl. 12 $56, \mathrm{pl} .15$ $39, \mathrm{pl}, 10$ $41, \mathrm{pl} .11$ $38,49,56$, pl. 15 $41, \mathrm{pl} .11$ $8,50-51,52$, pl. 13 $45, \mathrm{pl} .11$ $41, \mathrm{pl} .11$ 48, pl. 12 56 , pl. 15 63, pl. 18 39-40, pl.10 64, pl. 18 58, pl. 16 $48, \mathrm{pl} .13$ 19 , pl. 20 46,47, pl. 12 $42-43$, pl. 11 47 , pl. 12
Page

Elphidium, flexuosum.................................................. 42, 11

florentinae

frigidum -

georgianum ................. 50, pl. 13

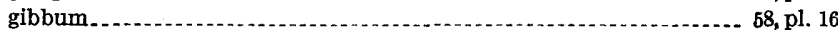

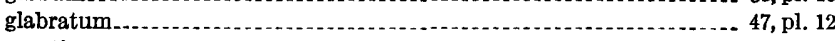

granti_............................................................. 69

granulosum

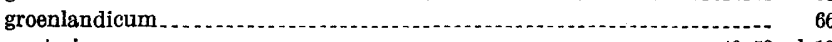

gunteri.......................... 49-50, pl. 13

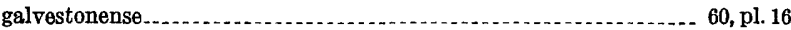

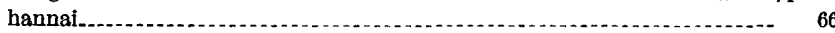

hauerinum............ 42 pl. 11

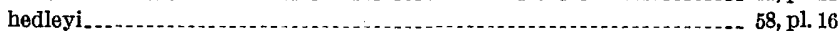

hispidulum ........................................................... 63, 18

howchini.......................................................... 41, pl. 11

hughesi-.............. 49, 65, pl. 13

foraminosum .................................................. 49, pl. 13

obesum

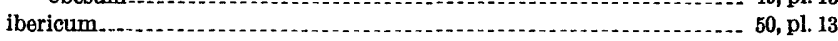

imperatrix - .

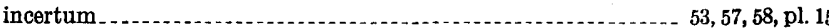

clavatum ............................................... 57-58, pl. 16

mexicanum.

indieum

inflatum

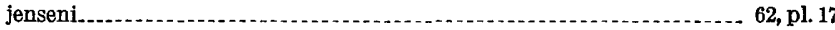

josephinum-....................... 43, pl. 11

laminatum ............................... 49, pl. 13

lanieri._.

latidorsatum

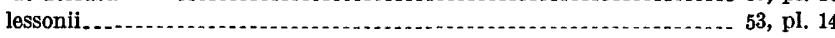

lidoense_........................................... 62-63, pl. 17

macellum ............................................... 48, 51-52, 67, pls. 14, 15

aculeatum .................................................... 52 pl. 15

granulosum.................. 52, pl. 14

limbatum....................................................... pl

tumidocamerale ....................................... 46, pl. 12

magellanicum

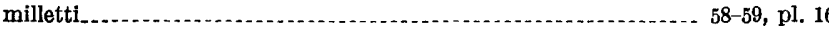

minimum

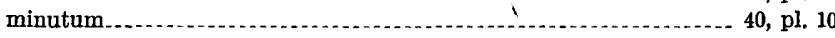

morenoi

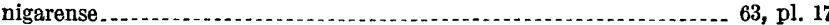

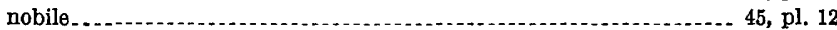

novo-zealandicum ................. 63, pl. 17

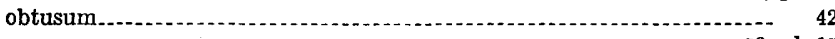

oceanense......................... 56, pl. 15

oceanicum............................................................. 59, pl. 16

oregonense-............. 19, 50, pl. 13

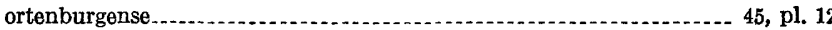

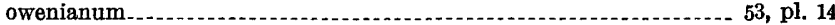

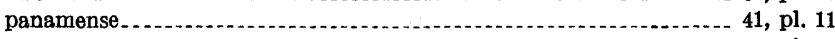

papillosum

parri

poeyanum

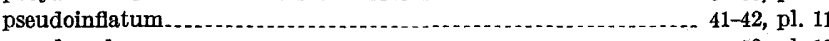

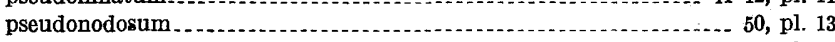

punctatum ....................................................... 49, pl. 13

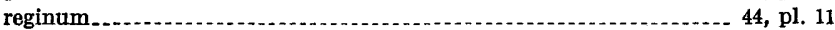

caucasicum

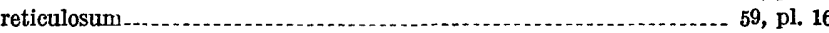

rugosum

sagrum_..._._.......... 55, pl. 15

salentinum $\ldots \ldots \ldots \ldots \ldots \ldots \ldots \ldots$

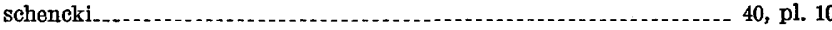

schmitti _._.

sculpturatum

selseyense_............................ 59-60, pl. 16

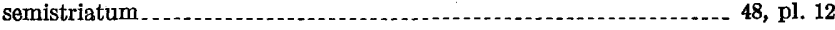

sibiricum

simplex

smithi

spinatum

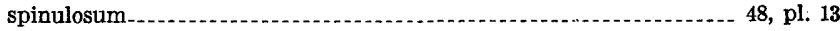

stella-boreale_........... 58, pl. 16

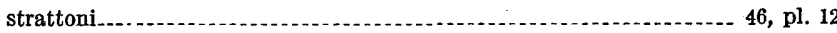

striato-punctatum -

subcarinatum................................................. 45

subevolutum ............... 63-64, pl. 18

subinflatum

subnodosum

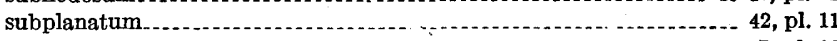

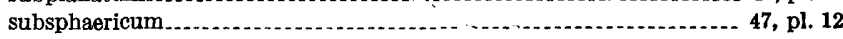


Page

Elphidium, subumbilicatum. centronondepressum

45, pl. 11

teretiusculum

texanum

translucens

tricostatum

tumidum

ungeri.

venustum.

verriculatum

$\mathrm{sp}$.

(Polystomella) advenum pontica. magellanicum

elyptica, Nonionina

elypticum, Nonion

Endothyra

45, pl. 11

- 48, pl. 13

. $39, \mathrm{pl} .10$

65, pl. 20

$46, \mathrm{pl} .12$

65, pl. 20

44-45, pl. 11

58, pl. 16

$61, \mathrm{pl} .17$

40,67, pl. 10

61

21

21, pl. 5

2,26

ythraea, Nonionina

escheri, Nonionina

etrusca, Polystomella

etruscus, Melonis.

evoluta, Polystomella striatopunctata

evolutum, Elphidium

excave.ta, Nonionina

Polystomella

excavatum, Elphidium

Nonion.

$39-40$, pl. 10

25

26
19,67

19,67
19

64, pl. 18

64, pl. 18

18
58

88, pl. 16

exoleta, Polystomella

exoletum, Elphidium

18 , pl. 5

exponens, Nonion

Nonionina.

extensa, Nonionella

Nonionina.

extensum, Nonion.

ezoense, Elphidium

48,48

24, pl. 6

28, pl. 7

14

14, pl. 4

19 , pl. 20

faba, Nautilus

Polystomella

fabum, Nonion.

falunica, Polystomella

falunicum, Elphidium.

falx, Nonion.

Nonionina

Faujasina

carinata.
orbignyi.

fayettei, Nonion hantken

Nonionella hantkeni.

fichteli, Polystomella.

fichtelliana, Polystomella

fichtellianum, EIphidium

fijiense, Astrononion.

fimbriatula, Polystomella

fimbriatulum, Elphidium

flexuosa, Polystomella

flexuosum, Elphidium .

florentinae, Elphidium.

floridana. Nonionina

Florilus.

florinense, Nonion.

flustrella, Nonionina.

foraminosum, Elphidium hughesi.
formosa, Nonionina............. 13

formosum, Nonion

fraasana, Nonionina

fraasanum, Nonion

frankei, Nonionella..

frigidum, Elphidium

fusca, Nonionina

$2-43$, pl. 11

$47, \mathrm{pl} .12$

42, pl. 11

ing$$
\text { in }
$$

gibbum, Elphidium

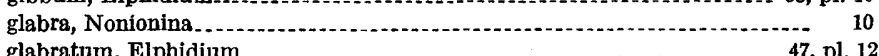

(la

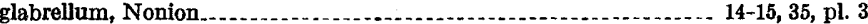

glabrum, Nonion.............. 10

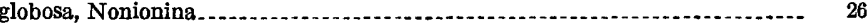

globulosa, Nonionina.

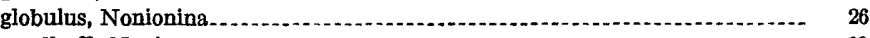

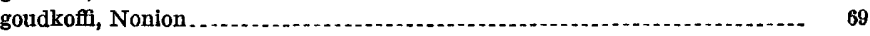

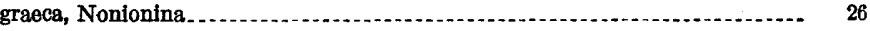

granifera, Nonionina

graniferum, Nonion.

granosum, Nonion

granti, Elphidium

granulata, Polystomella_

granulosum, Elphidium

Elphidium macellum ................................................ 52, 14

grateloupi, Nonion

Nonionina

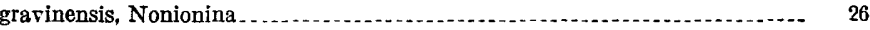

groenlandica, Elphidiella_..... 19

groenlandicum, Elphidium
gunteri, Elphidium

H

halkyardi, Nonion................... 8, pl. 2

hannai, Elphidiella_........... 8, pl. 19

Elphidium - 66

hantkeni, Nonion
Nonionella

Nonionella

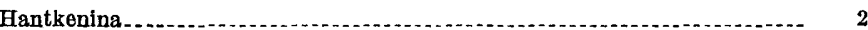

Haplophragmoides

Hastigerina

hauerina, Polystomella.

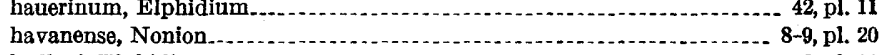

hedleyi, Elphidium

Polystomella . .

helicina, Nonionina

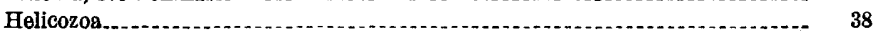

hemprichii, Nonionina

heteropora, Nonionina................................................................ 26

hispidulum, Elphidium

howchini. Elphidium

hughesi, Elphidium ....................................................... 13

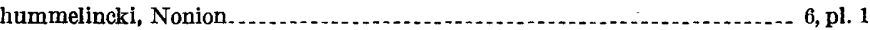

Nonionina..

hyalina, Nonionina.

ibericum, Elphidium.

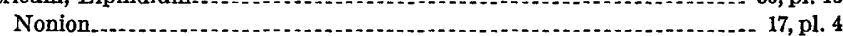

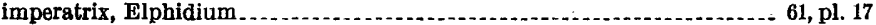

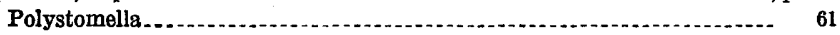

incerta, Polystomella umbilicatula

incertum, Elphidium.............................................. 53, 58, pls. 15, 16

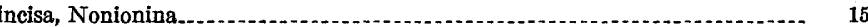

incisum, Nonion. .......... 4

incrassata, Nonionina 19

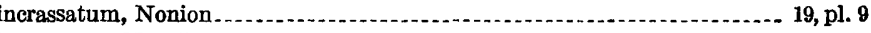

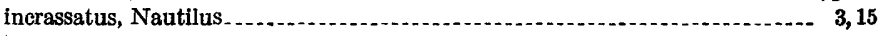

indicum, Elphidium

indigena, Polystomella.

inexcavata, Nonionina advena........... 7

inexcavatum, Nonion............. 7, pl. 2

inflata, Nonionina...
Polystomella

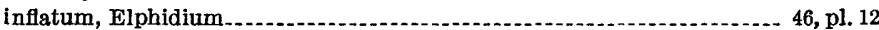

Nonion ............... 14, pl. 4

Nonion scaphum.

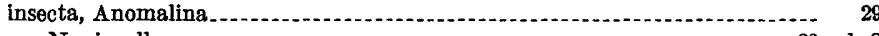

Nonionella $\ldots . . . . . . . .29$, pl. 8

integra, Nonionina.

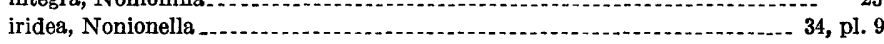

italicum, Astrononion.

gardnerae, Nonionella

Geoponus.

stella-borealis

38,58

georgianum, Elphidium

germanica, Nonionina

22

manicum, Nonion

jaccardi, Nonionina.

$\mathbf{J}$

jacksonensis, Nonionella

26
$29, \mathrm{pl}, 8$

janiformis, Nonionella

Nonionina boueana

$26,32, \mathrm{pl} .8$

- 26,32 
Page

japonica, Nonionella.

$32, \mathrm{pl}$.

japonicum, Pseudononion

27,32

jarvisi, Nonion.

jeffreysii, Nonionina

jenseni, Elphidium

Polystomella.

josephina, Polystomella

josephinum, Elphidium

3 , pl.

62, pl. 17

62

43, pl. 11

karreri, Polystomella.

kernensis, Nonion incisum

koldeweyi, Nonionina.

L

labradorica, Nonionina

labradoricum, Nonion

laeve, Nonion

laevigata, Nonionina

Polystomella.

laevigatum, Nonion

laevis, Nonionina

lamarcki, Nonion

Nonionina.

laminata, Polystomella.

laminatum, Elphidium

lanieri, Elphidium

Polystomella

lata, Nonionella

latescens, Nonion

Nonionina.

Laticarinina.

latidorsata, Nonionina

Polystomella.

latidorsatum, Elphidium.

Lenticulina.

leo, Nonion

Nonionina.

Lepidocyclina .

lessonii, Elphidium

Polystomelia.

lidoense, Elphidium

limba, Nonionina

limbata, Polystomella macella

limbato-striata, Nonionella

32 , pl. 8

mbatum, Elphidium macellum

52, pl. 14

limbum, Nonion

listeri, Polystomella

Lithothamnion.

43

M

macella, Polystomella

macellum, Elphidium

macellus, Nautilus.

magdenburgica, Nonionina

magellanicum, Elphidium .

Elphidium (Polystomella)

margaritaceum, Elphidium advenum.

marginatum, Nonion laeve...... 8, pl. 2

Marginulina

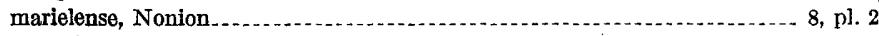

Material, available

questionable.

mediocostata, Nonionina

mediocostatum, Nonion.............. 15, pl. 4

melo, Nautilus

Nonion..

Nonionina

Melonis.

etruscus.

mesonense, Nonion

metagordanum, Nonion depressulum

metensis, Polystomell

Nonion

micrum, Nonion.

millepora, Nonionina

milletti, Elphidium

Polystomella

minima, Polystomella

minimum, Elphidium

minimus, Nautilus

minuta, Polystomella minutum, Elphidium

Page miocenica, Nonionella

40, pl. 10

Polystomellina

69,019

montereyanum, Nonion................. 16, pl. 4

morenoi, Elphidium............................... 16

multicameratum, Nonion pizarrense_...................................... pl. 4

Nonionina

$\mathrm{N}$

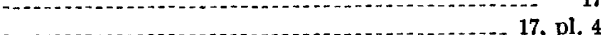

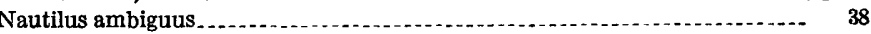

asterizans.......... 3,20

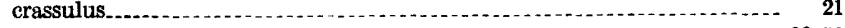

craticulatus._.

crispus.................... 38,50

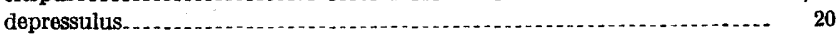

faba

incrassatus........ 3,19

macellus............ 58,51

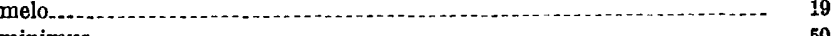

minimus

pompilioides.............. 3

scapha-1._.

strigillatus.................. 38 , pl. 15

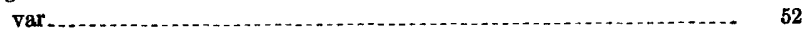

umbilicatulus........ 21

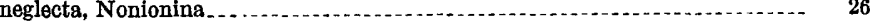

nicobarense, Nonion.............. 17, pl. 4

nigarense, Elphidium

nobile, Elphidium

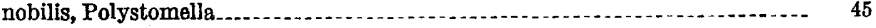

nodulosa, Nonionina

nodulosum, Nonion ................. 3, pl. 1

Nonion.....-. $9, \mathrm{pl} .20$

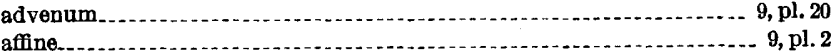

angustum............. 17, pl. 4

anomalinum

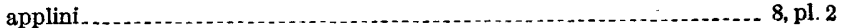

asterizans............ 5

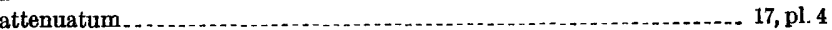

barleeanum ..... 6

belridgense $\ldots \ldots \ldots$

bonairense

boueanum..................................................... 112-13, 20, 3

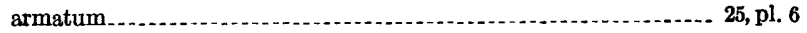

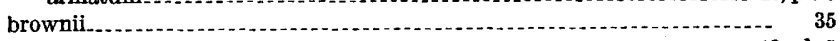

buxovillanum.

chapapotense

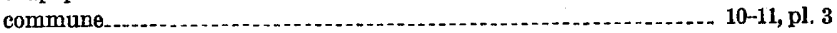

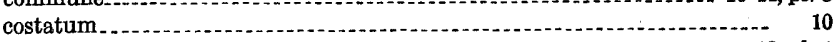

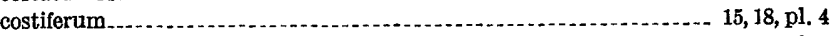

crassulum . . . . .

cretaceum

dense-punctatum

depressulum

metagordanum.

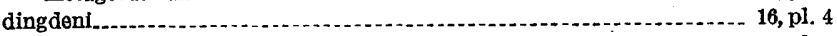

dollfusi.

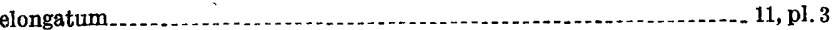

elypticum . .

excavatum

exponens . . .

extensum

fabum

alx

florinense
formosum

formosum fraasanum

galeatum . . . .

germanicum $\ldots$

glabrellum ............... 3

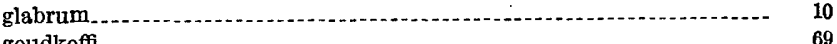

goudker.

graniferum. . .

grateloupi........... 21-22, 23, pl. 6

halkyardi................. 2

hantkeni fayettei.

havanense

hummelincki. 
Page

Nonion, incisum incrassatum. inexcavatum

inflatum

jarvisi.

labradoricum

laeve. marginatum

laevigatum

lamarcki.

latescens

limbum.

marielense

medio-costatum

melo

mesonense

mexicanum

micrum.

montereyanum

carmeloense

nautiloideum

nicobarense

nodulosum

novo-zealandicum

olsson

orbiculare

ornatissimum

pacificum.

pauper

pauperatum

perforatum

perfossum

pizarrense

basispinatum

multicameratum

planatum.

politum.

polystoma

polystomelliform

pompilioides

roemeri.

rude

rugosum...

samanicum

scaphum.

inflatum

schencki.

schwageri.

simplex.

sloanii.

soldanii.

solidum.

stachei.

stellatum.

striolatum

subangulosum

subcarinatum

subgranosa.

subturgidum

terquemianum

tuberculatum

turgescens

turgidus

umbilicatulum

pacificum

var.

victoriense

whitsettense

wilcoxense

ynezianum

Nonionella.

alabamensis.

auricula.

auris.

var.

austinana

chiliensis

clavata.

cockfieldensis

cretaces...

danvillensis

extensa

frankei

$5,69, \mathrm{pl}$.

$19, \mathrm{pl} .5$

7 , pl. 2

14, pl. 4

$-3, \mathrm{pl}$.

23, pl. 6

$3-4,10$, pl. 1

. 8, pl. 2

22. pl. 6

$1-12$, pls. 3,6

$4, \mathrm{pl} .1$

$14, \mathrm{pl} .4$

$19, \mathrm{pl} .5$

8, pl. 2

15, pl. 4

pl. 4
8, pl. 2

$6, \mathrm{pl} .1$

5-6, pl. 1

16, pl. 4

16, pl. 4

17, pl. 4

17, pl. 4

3 , pl. 1

16, pl. 3

$7, \mathrm{pl} .1$

23-24, pl. 6

7,pl. 2

25 , pl. 6

14, pl. 3

24, pl. 6

12 , pl. 3

$18, \mathrm{pl} .5$

18, 24-25, pl. 6

25 , pl. 6

$16, \mathrm{pl} .4$

4-5, pl. 1

22, pl. 5

$18, \mathrm{pl} .4$

19, pl. 5

10 , pl. 3

18. pl. 4

4, pl. 1

6, pl. 1
20, pl. 5

$8, \mathrm{pl} .2$

89
.$-- \quad 69$

17 , pl. 4

$14, \mathrm{pl} .4$

22-23, pl. 6

13,19 , pls. 3,4

- 3, pl. 1

. 16,pl. 3

- 4, pl. 1

18, pl. 4
-3. pl. 1

8,23 , pls. 5,6

s. 5,6
pl. 3

25, pl. 6

4, pl. 1

$13, \mathrm{pl} .3$

10, pl. 2

6
, pl. 5

25

$17, \mathrm{pl} .4$

$7, \mathrm{pl} .1$

(5, 1

$2,3,25,26-35$. pls. 7-9

$33-34$, pl. 9

$31,32,33$, pl. 9

$27, \mathrm{pI} .7$

$33, \mathrm{pl}, 9$

$31, \mathrm{pl} .8$

$29, \mathrm{pl} .7$

$27,28, \mathrm{pl}, 7$

$30, \mathrm{pl} .8$

28, pl. 7

$30-31$, pl. 8
Page

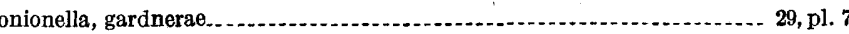

hantkeni....................................... 30, pl. 8

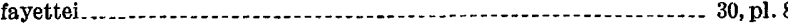

spissa . . .

insecta . . . .

iridea

jacksonensis $\ldots \ldots \ldots$

janiformis .................................. 26, 32, pl. 8

japonica........... 32, pl. 9

34-35, pl.

limbato-striata

miocenica . . .

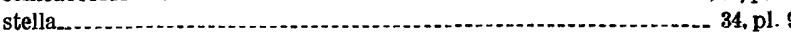

novo-zealandica $\ldots \ldots \ldots$

parri ............ 34, pl. 9

pseudo-auris.............. 31. pl. 8

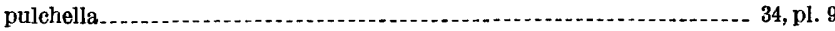

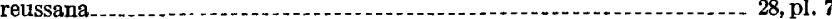

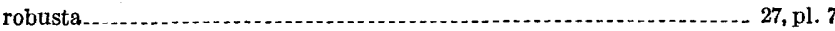

tatumi. . . .

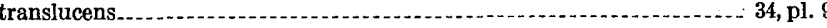

tredeca

turgida......... 26, 29, 32-33, pl. 9

warburgi

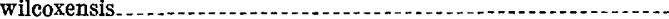

Nonionina

inexcavata.

affinis

aglajae.

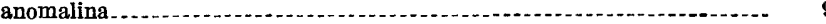

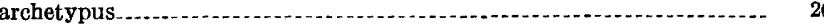

arctica

asterizans $\ldots$

turgida

astreae

attenuata.....

badensis.......................... 26

bathyomphala

bavarica

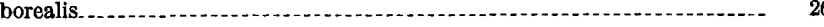

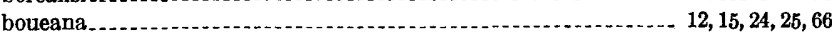

janiformis.

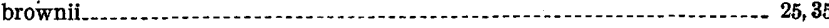

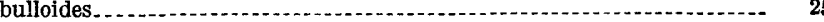

buxovillana. . . .

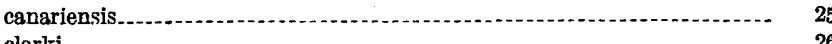

clarki

communis

costata.... - .

costifera

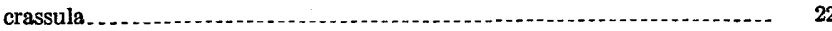

cretacea . . .

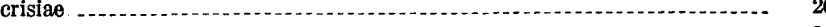

crystallina

dense-punctata. .

depressula

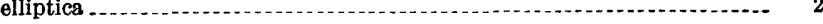

elongata

elyptica... . . . . .

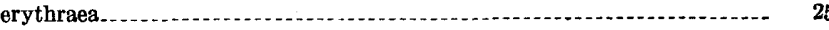

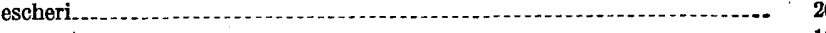

excavata.......... 18

exponens...

extensa

falx

floridana

flustrella

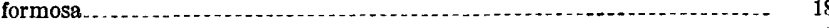

fraasana . . .

fusca. .

germanica

glabra

globosa.

globulosa.

globulus.

graeca. .

granifera.

granosa.-

grateloupi. 
Nonionina, gravinensis.

hantkeni.

helicins....

hemprichii.

heteropora...

hyalina.

incisa

incrassata.

inflata

integra

jaccardi.

jeffreysii.

koldeweyi.

labradorica

laevigata

laevis.

lamarcki.

latescens.

latidorsata

leo....

magdenburgica

magdenbur

mediocostata

melo

millepora

nautiloidea

neglecta.

nodulosa

nympharum

obliqua.

oblonga.

ocellata

olssoni.

orbicularis

ornata

pauper

pauperata

pelagica.

perforata

perfossa.

placenta

polita.

polystoma

polystomelliformi

pompilioides

punctata

quaternaria

quatriloba

quinqueloba

rotula.

rudis.

rugosa...

samanica

scapha.

bradii -

var

silicea.

simplex.

sloanii.

soldanii.

solida.

sphaerica

sphaeroides

spira

spirillina

splendida.

stellata.

stelligera.

striatula

striolata.

subangulosa

subcarinata

subgranosa

subturgida

tuberculata

turgida.

arenacea.

umbilicata

umbilicatula

pacifica

villeroensis

whitsettensis
Page

30

26

26

6

15

19

26

25
26

26

26

23

22

3

11
4

4
26

14

14
19

26

pl. 2

6,15

3, pl. 4

25
17

26

3

26
Page

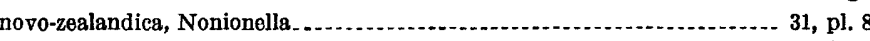

novo-zealandicum, Astrononion. . ........................................ 37, pl. 10

Elphidium . . . . . . . .

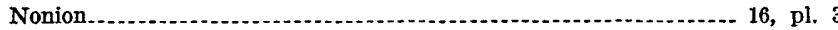

nympharum, Nonionina.

0

besum, Elphidium hughesi . ....................................... 49, pl. 13

obliqua, Nonionina

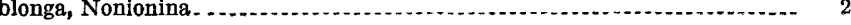

bscura, Polystomella................................................. 67

obtusa, Polystomella .

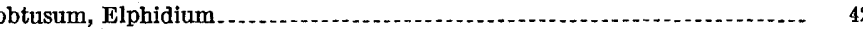

oceanense, Elphidium .

oceanensis, Polystomella . ................................................... 56

oceanicum, Elphidium

ocellata, Nonionina

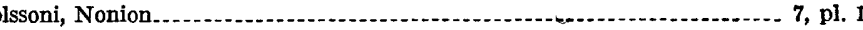

Nonionina

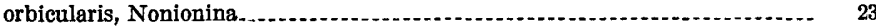

orbiculatum, Cornu Hammonis. . ............................................ 50

orbignyi, Faujasina

oregonense, Elphidium

ornata, Nonionina

Polystomella . .

ornatissimum, Nonion........ 7, pl, 2

ortenburgense, Elphidium........................................... 45, pl. 12

ortenburgensis, Polystomella..................................................... 45

oweniana, Polystomella

owenianum, Elphidium ........... 53, pl. 14

tongaensis.

$\mathbf{P}$

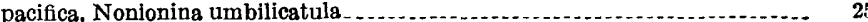

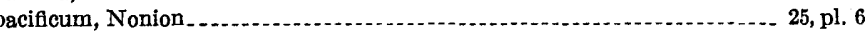

Nonion umbilicatulum.

panamense, Elphidium. . . .

papillosum, Elphidium

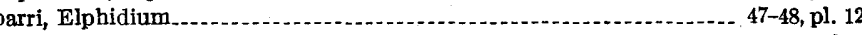

Nonionella............

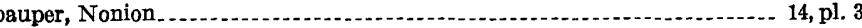

Nonionina

pauperata, Nonionina

pauperatum, Nonion.......... 24, pl.

pelagica, Nonionina

Peneroplis............... 67

perforata, Nonionina.

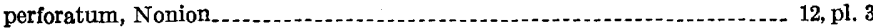

perfossa, Nonionina............... 18

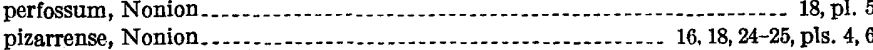

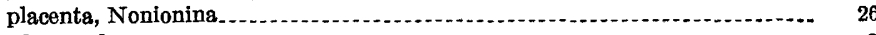

Placentula

planatum, Nonion

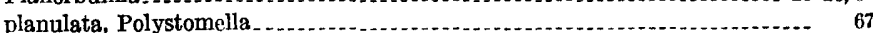

Planulina affinis....................... 9

poeyana, Polystomella.

poeyanum, Elphidium

polita, Nonionina
politum, Nonion.

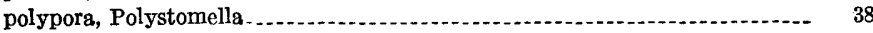

polystoma, Nonion................ 18, pl. 4

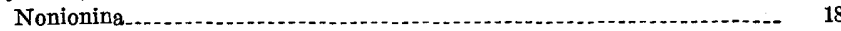

Polystomella. ........... $3,8,21,38-39,65,67$

aculeata................. 44

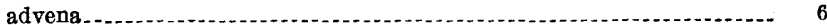

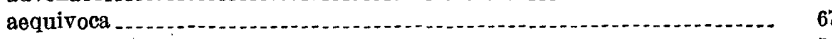

alvareziana .

angularis.

angulata.

antonina

arctica.

articulata

berthelotian

burdigalensis

calcar.

canariensis

chipolensis.

complanata

costifera. 


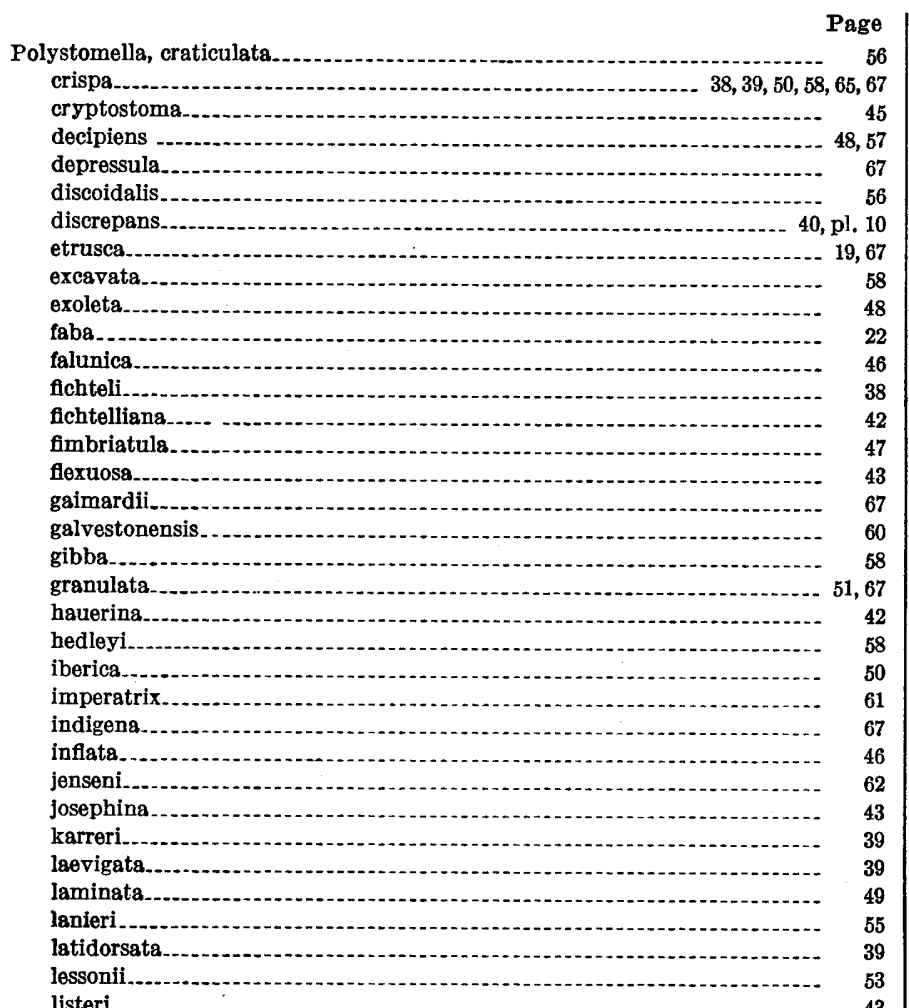

\section{polystomelliformis, Nonionina}

Page

Polystomellina.

(1) 19

pompilioides, Nautilus. 19

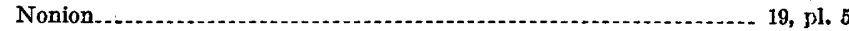

Nonionina.......... 19

pontica, Elphidium (Polvstomella) advenum

ponticum, Elphidium advenum .................................. 17

pseuđo-auris, Nonionella........................................ 8

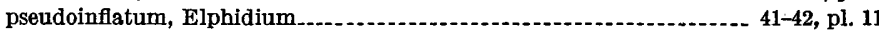

pseudonodosum, Elphidium.

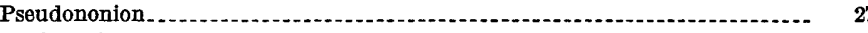

japonicum

tredecum

pulchella, Nonionella

Pullenia_.....

elongata

Pulvinulina affinis.......
Pulvinulus

punctata, Nonionina...........

punctatum, Elphidium

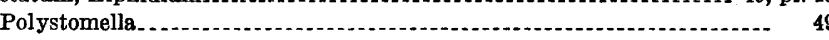

Q

quaternaria, Nonionina.

quaterpunctata, Polystomella......

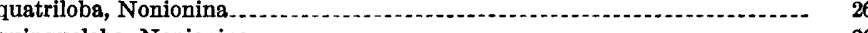

quinqueloba, Nonionina

reginum, Elphidium
reticulosum, Elphidium

reussana, Nonionella_...

rigatus, Themeon

Robulina

subnodosa......... 40

Robulus

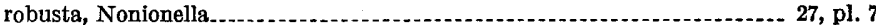

roemeri, Nonion........ 10, pl. 3

Rotalina turgida_... 32

rotula, Nonionina .

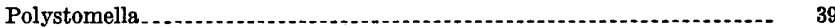

rude, Nonion . ...

rudis, Nonionina

rugosa, Nonionina

rugosum, Elphidium

Nonion

rugulosum, Elphidium articulatum .................................... 1

polypora

punctatum.

quaterpunctata

regina.

rotula

rugosa

sagra.

salentina

savii.

semistriats

sibirica.

spinulosa.

stella-borealis

strattoni.

striato-punctats

evoluta.

selseyensis.

triolata.

subaculeata.

subcarinata.

subnodosa...

subumbilicata

tenuissima.

teretiuscula

texana.

tricostata.

umbilicata.

umbilicatula

incerta

ungeri.

venusta...

verriculata

vulgaris

sp..

polystomelliforme, Nonion

$1819-39-10$

$49,54,55,57,58,59,60$

64, pl. 18

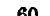

52,67 sagra, Polystomella

sagrum, Elphidium.

salentina, Polystomella

(1)

samanicum, Nonion

savii, Polystomella

scapha, Nautilus.
Nonionina

scaphum, Nonion.............. 8, 9, 20, pls. 2,

schencki, Elphidium.

Nonion.

schmitti, Elphidium ............... 58, pl. 16

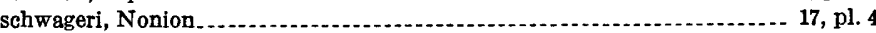

sculpturatum, Elphidium

selseyense, Elphidium

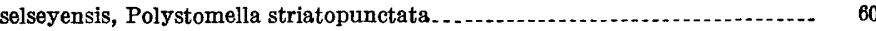

semistriata, Polystomella.

semistriatum, Elphidium.

serrulatum, Elphidium alvarezianum .................................. 54, pl. 14

sibirica, Elphidiella

Polystomella . . . .

sibiricum, Elphidium

sidebottomi, Astrononion............. 36, pl. 10

simplex, Elphidium

Nonion $\ldots$

Nonionina

sloanii, Nonion.

Nonionina.

smithi, Elphidium.......... 40

soldanii, Nonion ...................................................... pls. 4 
soldanii, Nonionina. Page solida, Nonionina

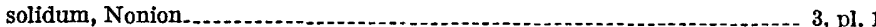

Sorilus.

sphaerica, Nonionina

sphaeroides, Nonionina

spinatum, Elphidium

spinulosa, Polystomella

spinulosum, Elphidium

spira, Nonionina.

spirillina, Nonionine

spissa, Nonionella hantken

splendida, Nonionina

stachei, Nonion

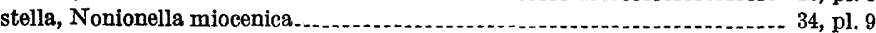

stella-boreale, Elphidium . ....... _...

stella-borealis, Geoponus........... 38, 58

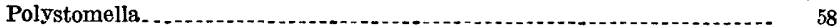

stellata, Nonionina

stellatum, Astrononion

Nonion -.. 4, pl. 1

stelligera, Nonionina....................... 35, 36, 37

stelligerum, Astrononion...................... $36,37,38$, pl. 10

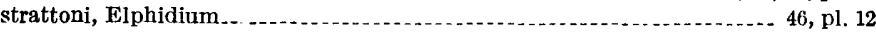

Polystomella.

striato-punctata, Polystomella_..... 49, 54, 55, 57, 58, 59, 60, 64, pl. 18

striato-punctatum, Elphidium _................ $38,47,52-53$, pl. 14

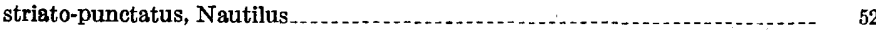

striatula, Nonionina

strigillatus, Nautilus.................. 15

striolata, Nonionina.

Polystomella.

striolatum, Nonion

subaculeata, Polystomella

subangulosa, Nonionina

subangulosum, Nonion

subcarinata, Nonionina

Polystomella

subcarinatum, Elphidium

Nonion

subevolutum, Elphidium

subgranosa, Nonion.

Nonionina.

subinflatum, Elphidium

subnodosa, Polystomella

Robulina.

lphidium

subplanatum, Elphidium

subsphaericum, Elphidium

subturgida, Nonionina

subturgidum, Nonion.....

subumbilicata, Polystomella

subumbilicatum, Elphidium

-. 52,67

$18, \mathrm{pl} .4$

szaboi, Clavulina.$$
\text { T }
$$

tatumi, Nonionella

teretiuscula, Polystomella.

8,23 , pls. 5,6

$63-64$, pl. 18 teretiusculum, Elphidium.

Page

terquemianum, Nonion

48 , pl. 13

terquemianum, Nonion.

4, pl. 1

texanum, Elphidium

38

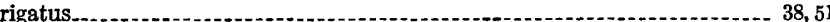

tongaensis, Ozawaia_._.

translucens, Elphidium ................ 65, pl. 20

Nonionella

tredeca, Nonionella

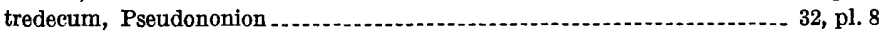

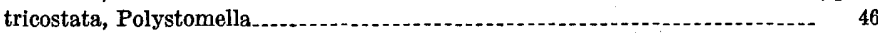

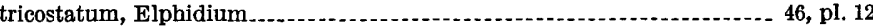

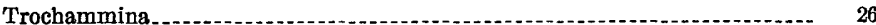

Truncatulina lobatula

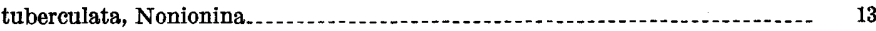

tuberculatum, Nonion

tumidocamerale, Elphidium macellum................................. 46, pl. 12

tumidum, Astrononion.

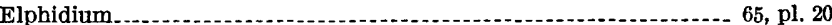

turgescens, Nonion

turgida, Nonionella

Nonionina

Nonionina asterizans. . .

Rotalina

turgidus, Nonion

Nonionina

Polystomella.

umbilicatula, Nonionin a

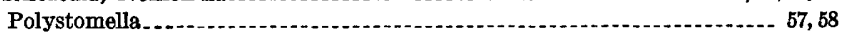

umbilicatulum, Nonion.

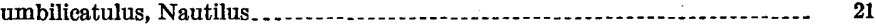

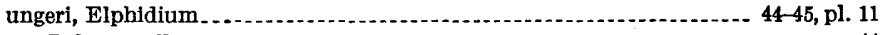

Polystomella

V

Valvulina auris

(1)-..-

venusta, Polystomella.

venustum, Elphidium

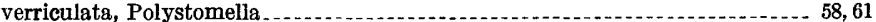

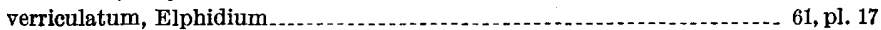

victoriense, Nonion

villeroensis, Nonionina. . . . . . . .

viragoense, Astrononion

Vorticialis.................. 38

vulgaris, Polystomella

W

warburgi, Nonionella_................... 7

whitsettense, Nonion.....

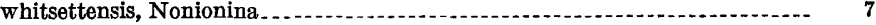

wilcoxense, Nonion

wilcoxensis, Nonionella

ynezianum, Nonion................................ 


\section{DRCE LISTS}

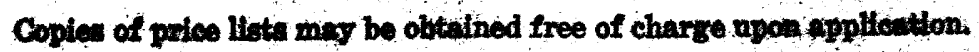

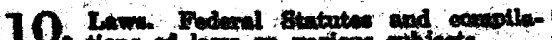
10. Hons of lines on varions wibjeate.

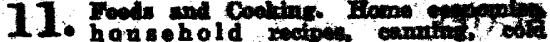
hons se

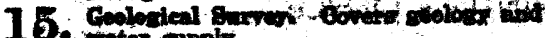

Thar apply.

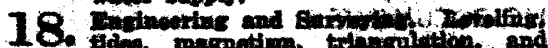

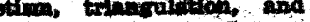

19. Ans and Monte Manusle, statton, 19. odinewe pemphlets, pendoas.

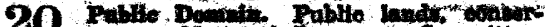

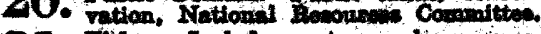

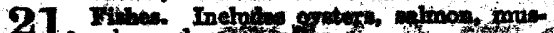

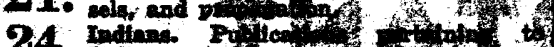

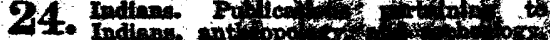

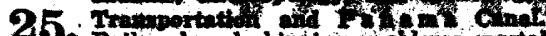

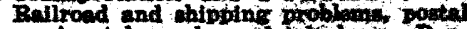

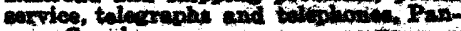
and Cinil.

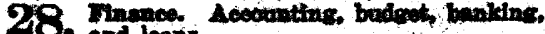

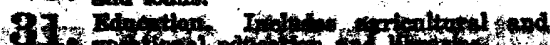

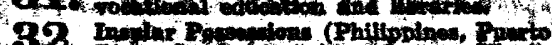

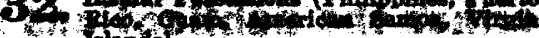
Alanith

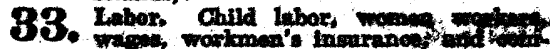
remention.

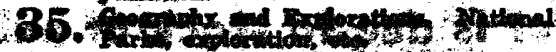

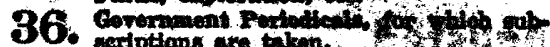

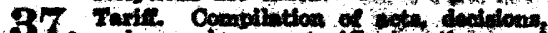

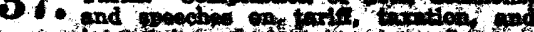

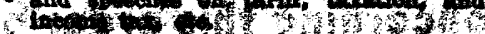

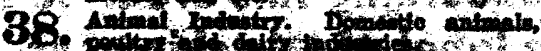

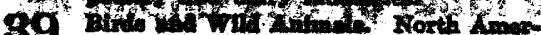

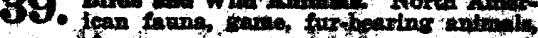

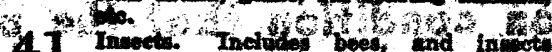

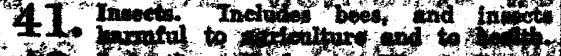

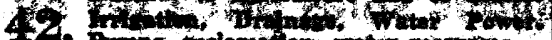

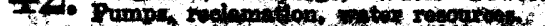

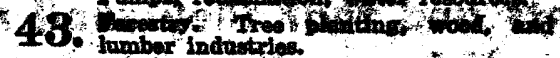

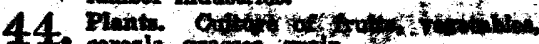

1. coreals, gratem, erila.

46. Boall Conitruetton, iniprom and

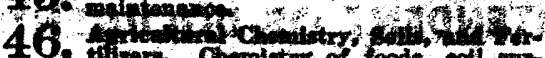

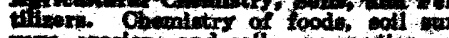

vers crodon, and ofi conteovition.

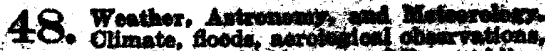

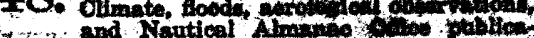
1) in that

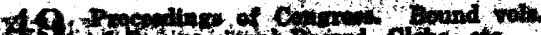

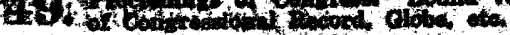

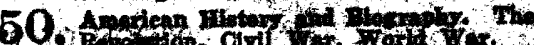

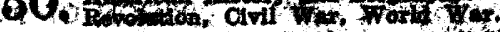

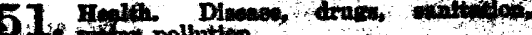

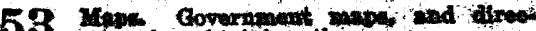
20. tion: for obtalinat then.

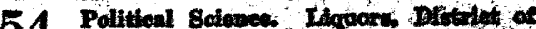

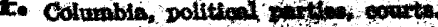

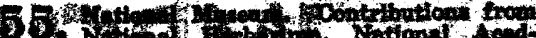

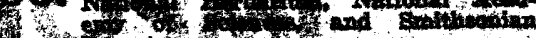

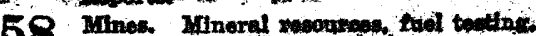

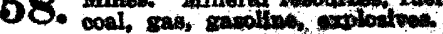

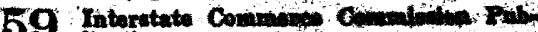

- Leatlone.

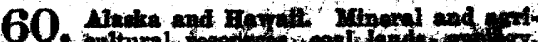

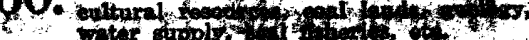

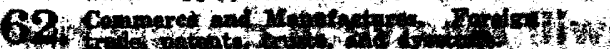

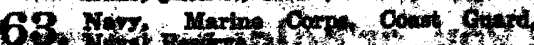

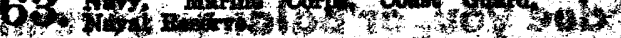

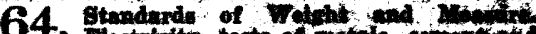

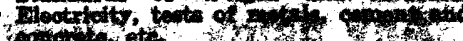

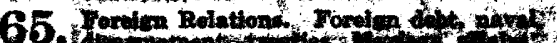

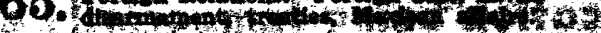

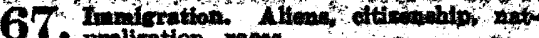

6 valieation, rages.

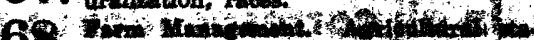

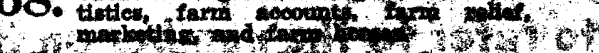

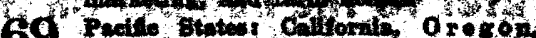

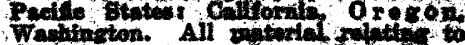

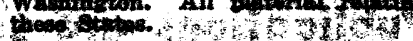

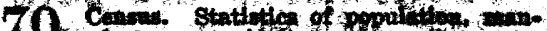

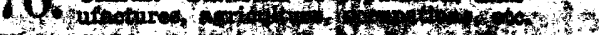

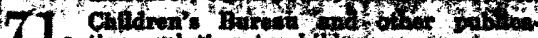

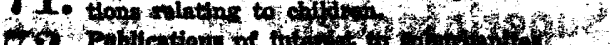

72. Fulfewliont of fit

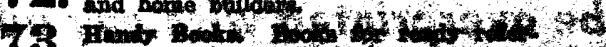

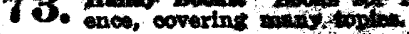

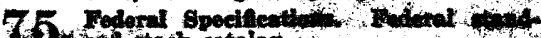

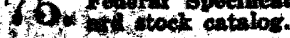

Lint of Radio Pulluonum

150,19

A Weekly Lit of Salocted Unitid States Gorernment Publicatione for of by the Superintendent of Documeats, arranged alphabetically by whects, with annotations and prices tray be obthined free upon applitestions 1 wish to keap in touch with the issuance of all United States public decuments, place a subseription for the Manthly Catalog of U. \&. Public becuments thich is priced at $\$ 1.50$ a year domestie delivery, and $\$ 2.10$ per year foraicn. This catalog lints the publications of all otpintments issued during each monts. whether for sale or otherwise, quoting prices in all instances where thes whil cations axe for beda.

\section{How to Remit}

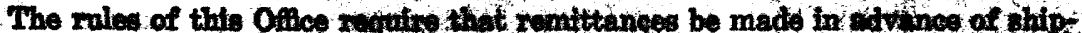
ment of publications, etther br 0 ppons, sold ta sets of 20 for 11 and mod unt

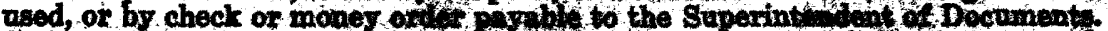

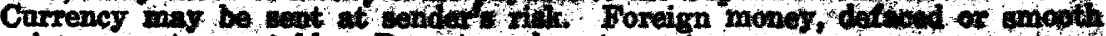
coins are not eccopteble. Do pot wand postage stamps.

Postage is not required for shlpment within the United atwles, incledin.

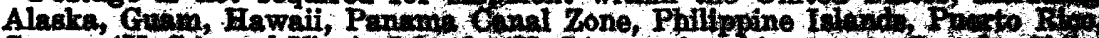

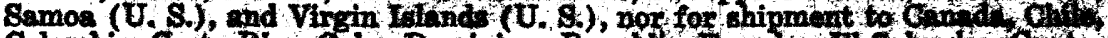

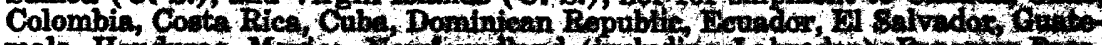

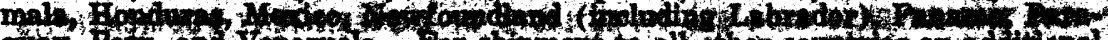

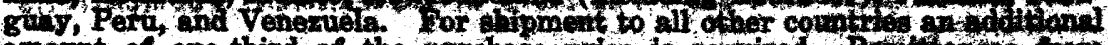

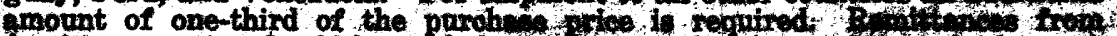

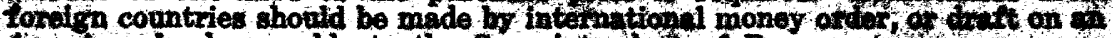

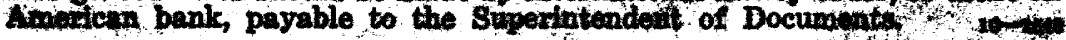




\section{UNITED STATES}

GOVERNMENT PRINTING OFFICE

DMISION OF PUBLIC DOCUMENTS

WASHINGTON, D.C.

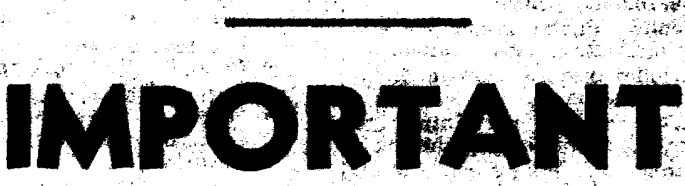

If your order is not completed in thits dellyentir you will receive in a short time elther the pabilieotions shil due you, or balence of remittunce.

Any delay in filling order is duesto stock of publlcation being temporanily exhausted.

In all correspondence concerning thib orden be sure to refer to the number on the label of this allpment.

Publications are sold on condition that the parchasers will odhere to the publie sales pilee sat by the Superintendent of Documents and that they shelly not be overprinted with any advertiaing mather.

\section{SUPERINTINDENT OE DOCUMENTS.}

Than 8D-11 